\title{
Habitação Camponesa: Entre o projeto e a produção no PNHR
}

Angel Castañeda Rodriguez

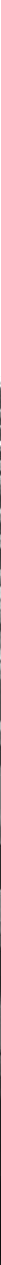




\section{Habitação Camponesa:}

Entre o projeto e a produçáo no PNHR

Tese apresentada ao Programa de Pós-

Graduação do Instituto de Arquitetura e Urbanismo, da Universidade de São Paulo, para obtenção do título de Doutor em Ciências.

Área de Concentração: Arquitetura, Urbanismo e Tecnologia 
 \\ Candidato(a): Angel Stive CastanedaRodriguez}

Título da tese: "Habitação camponesa:entre o projeto e a produçãono PNHR"

\section{Data da defesa: 27/11/2020}

Ficha catalográfica elaborada pela Biblioteca do Instituto de Arquitetura e Urbanismo com os dados fornecidos pelo autor

\begin{tabular}{|c|c|}
\hline \multirow[t]{3}{*}{ cc346h } & $\begin{array}{l}\text { Castañeda Rodriguez, Angel Stive } \\
\text { Habitaçâa Camponesa: Entre o projeto e a produçáo } \\
\text { no PNHR / Angel Stive Castaneda Rodriguez; } \\
\text { orientadora Akemi Ino. -- São Carlos, } 2020 . \\
265 \text { p. }\end{array}$ \\
\hline & $\begin{array}{l}\text { Tese (Doutorado) - Programa de Pós-Graduaçáo em } \\
\text { Arquitetura e Urbanismo, Arquitetura, Urbanismo e } \\
\text { Tecnologia -- Instituto de Arquitetura e Urbanismo, } \\
\text { Universidade de Săo Paulo, } 2020 \text {. }\end{array}$ \\
\hline & $\begin{array}{l}\text { 1. habitação camponesa. 2. programa habitacional. } \\
\text { 3. forma de produção. 4. projeto. 5. canteiro. I. } \\
\text { Ino, Akemi, orient. II. Título. }\end{array}$ \\
\hline
\end{tabular}

Bibliotecária responsável pela estrutura de catalogação da publicação de acordo COM a AACR2: Brianda de Oliveira Ordonho Sígolo - CRB - 8/8229

\section{Orientadora: Profa. Dra. Akemi Ino}

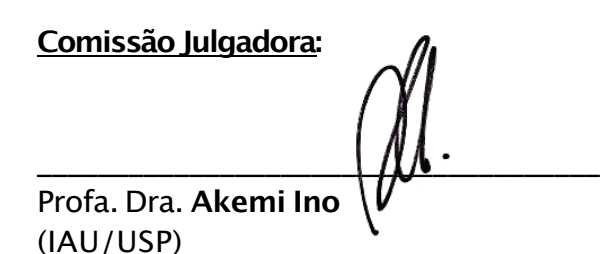

Resultado:

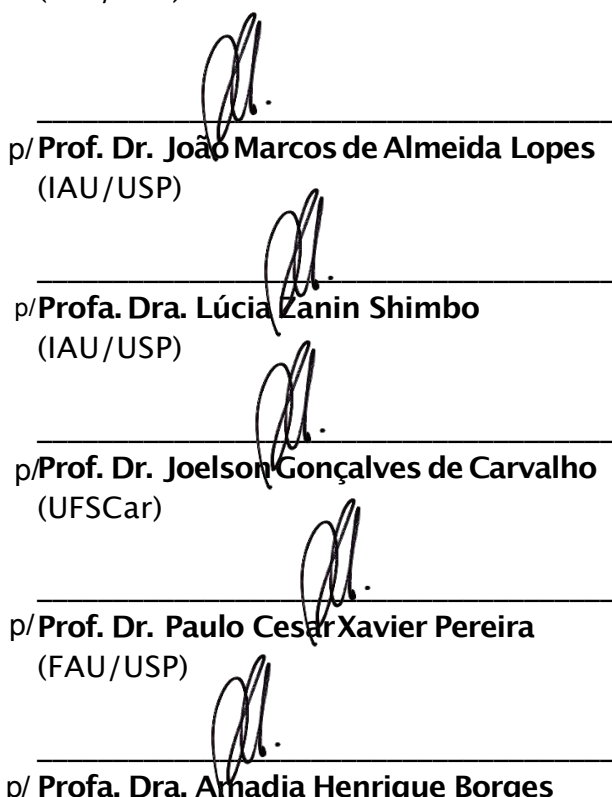

\section{Não votante}

Aprovado

Aprovado

Aprovado

Aprovado

Aprovado 


\section{Agradecimentos}

Agradeço a todos e todas que contribuíram direta ou indiretamente para que esta pesquisa fosse possível.

Em especial agradeço à minha orientadora, a Profa. Akemi Ino, pelo apoio e incentivo no decorrer de todo este processo, pela sua dedicaçao e pelas suas observaçoes, sempre oportunas e fundamentais para a elaboraçáo desta tese. Da mesma maneira, agradeço à Profa. Lúcia Zanin Shimbo e ao Prof. Joáo Marcos de Almeida pelas ajudas e orientaçóes

Agradeço também aos meus amigos e colegas da equipe "Universal": Anaïs Guéguen, Caio de Souza, Cecília Lenzi, Flia Montolio Alagarda, Esaiy Valdenebro, Fernanda Seleguim Lizeth Ardila, Mathilde Teixeira Col e Rodolfo Sertori pelas horas de reflexáo compartilhadas e trabalho duro em equipe. Sem vocês, esta tese não teria sido possível!

À equipe e amigos do Grupo Habis do IAU/USP, Camila Furloni, Camila Rocha, Carlo Radaik, Erich Shigue, Fred Ghellere, Iole Almança de Morais, Lara Melotti, Marco Partel Murillo, Mariana Tórtura, Mariusa Henriquez, Mônica Duarte Aprilanti, Simone Tavares, Tatiana de Oliveira Chiletto, Thiago Ferreira, pelo companheirismo, boas conversas, troca de experiências e pela amizad

Aos entrevistados, famílias camponesas moradoras dos assentamentos rurais, assessores

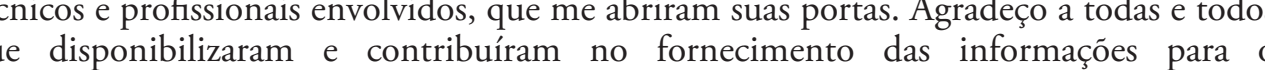
que disponibilizaram e contrit
desenvolvimento desta pesquisa.

Este caminho acadêmico náo seria possível sem o apoio da minha amada FAMILIA. Dedico esse trabalho aos meus pais, Ducardo e Argenis, pela paciência, estímulo e apoio no decorrer desta longa jornada, à minha irmá, Nata, sempre acompanhando e torcendo apesar da distância, à minha irmá, Sonia (in memoriam) por serem meu norte. A minha pelos belos momentos cheios de alegria. Agradeço a vocês por simplesment Jexistir e ser parte da minha vida! 


\section{Resumo}

CASTAŇEDA, Rodríguez Angel. Habitaçáo Camponesa: Entre o projeto e a produçáo no PNHR. 2020. 265 f. Tese (Doutorado em Arquitetura e Urbanismo) - Instituto de Arquitetura e Urbanismo da Universidade de São Paulo. São Carlos, 2020.

O Programa Nacional de Habitação Rural (PNHR), modalidade do Programa Minha Casa Minha Vida (MCMV), apesar de não ter cifras táo expressivas em termos de recursos ou unidades produzidas, se comparadas com as cidades, produz um impacto considerável no território, passível de ser estudado. Não precisamos ir muito a fundo para perceber que náo existe uma política clara de habitaçáo social no campo brasileiro, claramente econômicos da dimensão urbana que acaba sendo induzida, ainda que indiretamente, por algumas das principais contradicōes colocadas pelo Programa MCMV. Diante deste contexto, com um programa de habitaçăo rural baseado na produçăo habitacional em escala, estruturada a partir de subsídios públicos e se submetendo na lógica do modelo capitalista de produçáo da habitaçáa social - decorrente das contradiçōes resultantes desta relaçăo - acaba conferindo à esfera privada a iniciativa e a responsabilidade pela qualidade dos empreendimentos produzidos e entregues à populaçăo. Isto traz como resultado inevitável a imposiçáo de padrōes produtivos que se sobrepóem às condiçōes destas nas áreas rurais em outro patomar de reflexáo, integrando as ańlises referida à p̧o soçăo

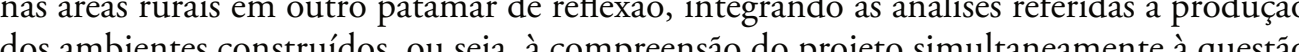
fundiária, ao financiamento, à articulaçáo de agentes, aos processos tecnológicos e de producáa e ao trabalho em canteiro de obras. A partir disso, o propósito desta tese é descrever e analisar como se dá a consolidaçáo dos processos de produçáo habitacional camponesa em três assentamentos de reforma agrária da Regiáo Oeste do estado de SP, no âmbito do PNHR, vinculado ao Programa Minha Casa, Minha Vida. Para tanto, a pesquisa é estruturada em três abordagens empíricas, que comumente săo tratadas como temas separados, porém, aqui seráo estudados paralelamente: i) o arranjo produtivo, a casss procurando compreender suas características, funçóes e dinâmicas na restáo das estudada; ii) tecnologia e processos de produçán em conteiro mostrando a interaçáo dos diferentes tipos de tecnologias com as condicóes próprias do lugar, fato que acaba alterando, o espaço construído, a natureza organizacional e a posiçấo do trabalhador neste processo; e iii) o projeto, sua relaçáo com o processo produtivo, o concebido ante o executado e o lugar do arquiteto na formulaçáo de soluçóes para estes territórios.

Palavras-chave: habitação camponesa, programa habitacional, forma de produçāo, projeto, canteiro, assentamentos rurais.

\section{Abstract}

CASTANNEDA, Rodríguez Angel. Peasant Housing: Between project and production at PNHR. 2020. 265 f. Tese (Doutorado em Arquitetura e Urbanismo) - Instituto de Arquitetura e Urbanismo da Universidade de São Paulo. São Carlos, 2020.

The National Rural Housing Program (PNHR), modality of the My Home My Life Program (MCMV), despite not having such expressive figures in terms of resources or units produced, when compared to the cities, produces a considerable impact on the territory that can be studied. We do not need to go too deep to realize that there is no clear social housing policy in the Brazilan countyside, clearly disjointed from social which ends up being induced even if indirectly by some of the min ictions posed by the MCMV Program. IIn this context, with a rural housing program based on housing
production in scale, structured based on public subsidies and subjecting itself to the logic of the capitalist model of social housing production - resulting from the ictions resulting from this relationship - it ends up giving the private sphere the initiative and responsibility for the quality of the enterprises produced and delivered to the population. This inevitably results in the imposition of production patterns that overlap with the conditions of these local communities. In this way, it is essential to raise the issue of social housing in rural act simultaneously with the land issue, financing the articulation of agents, technological and production processes and work on construction sites. The purpose of this thesis is to describe and analyze how the processes of peasant housing production are consolidated in three agrarian reform settlements in the western region of the state of SP, within the framework of the PNHR, linked to the My Home, My Life Program. To this end, the research is structured in three empirical approaches, which are commonly treated as separate themes, but here they will be studied in parallel: i) the productive arrangement, the categorization of the different agents that act in the constructive and management in the studied relity, ii) technogy and production processes on site, showing the interaction of the different types of technologies with the conditions of the place, a fact that ends up changing, the built space, the organizational nature and the position of the worker in this process; and iii) the project, its relation with the productive process, the one conceived before the executed one and the architect's place in the formulation of solutions for these territories.

Keywords: peasant housing, housing program, form of production, project, construction site, rural settlements. 


\section{Resumen}

CASTAÑEDA, Rodríguez Angel. Vivienda Campesina: Entre el proyecto y la producción en el PNHR. 2020.265 f. Tese (Doutorado em Arquitetura e Urbanismo) -
Instituto de Arquitetura e Urbanismo da Universidade de São Paulo. São Carlos, 2020.

El Programa Nacional de Vivienda Rural (PNHR), modalidad del Programa Mi Casa Mi Vida (MCMV), a pesar de no tener cifras tan expresivas respecto a recursos o unidades producidas, si se compara con las ciudades, produce un impacto considerable en el territorio, idonneo para ser estudiado. No es necesario ir demasiado lejos para darse cuenta desarticulada de las políticas de desarrollo socil, dependiente en términos políticose económicos de la dimensión urbana que termina siendo inducida, por algunas de las principales icciones del Programa MCMV. Frente a este contexto, con un programa de vivienda rural basado en la producción de viviendas a gran escala, estructurado a partir de subsidios públicos y sometido a la lógica del modelo capitalista de producción de viviendas sociales - resultante de las icciones derivadas de esta relación - termina por confiar a la esfera privada la iniciativa y la responsabilidad de la calidad de los proyectos habitacionales producidos y entregados a la población. Esto trae como resultado inevitable la imposición de estándares productivos que se sobreponen a las condiciones de estas comunidades locales. Por lo tanto, se torna fundamental situar la cuestión de la vivienda social rural en ambientes construidos, es decir, omprendiendo el proyecto simultáneamente con la cuestión del suelo, la financiación, la articulación de los agentes, los procesos tecnológicos y productivos y el trabajo en obra. Con base en esto, el propósito de esta tesis es describir y analizar cómo se lleva a cabo la consolidación de los procesos de producción de viviendas campesinas en tres asentamientos de reforma agraria en la Región Occidental del Estado de SP, en el marco del PNHR, vinculado al Programa Minha Casa, Minha Vida. La investigación está estructurada en tres enfoques empíricos, que comúnmente se tratan

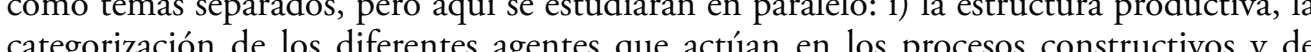
categorización de los diferentes agentes que actuan en los procesos constructivos $y$ de en la realidad estudiadar ii) la tecnología y los procesos de producción in situ mostrando la interacción de los diferentes tipos de tecnologías con las condiciones propias del lugar hecho que acaba alterando el espacio construido, la naturaleza organizacional y la posición del trabajador en este proceso; y iii) el proyecto, su relación con el proceso productivo, el concebido ante el ejecutado y el lugar del arquitecto en la formulación de soluciones para estos territorios.

Palabras clave: vivienda campesina, programa habitacional, forma de producción, proyecto, obra de construcción, asentamientos rurales.

\section{Lista de Figuras}

Figura 01. Concentração fundiária, Brasil 2017

Figura 02. Linha de tempo dos programas habitacionais para o campo - Brasil, período 1999 a 2016.

Figura 03. Unidades contratadas pelo PNHR por ano - Brasi

Figura 04. Produçáo do PNHR no estado de Sáo Paulo (até 2018).

Figura 05. Estrutura operacional do PNHR

Figura 06. Localizaçáo dos três assentamentos estudados.

Figura 07. Projeto Padrão do Pró-Lar Rural - CDHU.

Figura 08. Moradores do assentamento trabalhando na construçăo de duas casas.

Figura 09. Linha do tempo do contrato das 120 Casas

Figura 10. Problemas identificados em 17 casas pela açáo do vento

Higura 11. Fundaçoes das casas (estacas cilindricas e vigas baldrame); laje de concreto.

Figura 12. Linha do tempo do contrato das 44 Casas

Figura 13. Linha do tempo do contrato das 26 Casas

Figura 14. Fachada do galpão; vista interna do galpáo da Empresa $\mathrm{C}$ com alguns materiais.

Figura 15. Linha do tempo do contrato das 27 Casas

Figura 16. Revestimentos cerâmicos e etapa de reboco exterior das 27 casas.

Figura 17. Linha do tempo resumo dos contratos $(120,44,26$ e 27 casas)

Figura 18. Organograma do contrato das 120 casas

Figura 19. Organograma do contrato das 44 casas

Figura 20. Organograma do contrato das 26 casas

Figura 21. Organograma do contrato das 27 casas

Figura 22. Organograma do contrato das 10 casas

126 Figur 26. Esocs Figura 27. Re resas de cobertua

Fig 28. L L

Figura 29. Projeto inicial de parcelamento do assentamento Florestan Fernandes

Figura 30. Localizaçáa dos canteiros das 120 casas (Florestan Fernandes)

Figura 31. Localizaçăo dos canteiros das 44 casas (Florestan Fernandes)

Figura 32. Localização do assentamento Boa Esperança 
Figura 33. Localização dos canteiros das 26 casas (Boa Esperança)

Figura 34. Localização do assentamento Dona Carmem

Figura 35. Localizaçáo dos canteiros das 27 casas (Dona Carmem)

Figura 36. Localização dos canteiros das 10 casas (Dona Carmem)

Figura 37. Infraestrutura para a produçáo habitacional do assentamento Florestan Fernandes

Figura 38. Infraestrutura para a produçấo habitacional do assentamento Boa Esperança

Figura 39. Galpão alugada pela Empresa C: estoque de materiais; pré-fabricação de componentes

Figura 40. Infraestrutura para a produçáo habitacional do assentamento Dona Carmen

Figura 41. Sistema construtivo usado nas 120 casas: alvenaria autoportante com blocos cerâmicos de 8 furos

Figura 42. Sistema construtivo usado nas 27 casas: estrutura em concreto armado e alvenaria de vedaçáo

Figura 43. Cortes na alvenaria para passagem de instalaçoes (120 e 44 unidades)

Figura 44. Projeto original de fundaçôes (esq); fundaçōes em estaca (der) (44 unidades)

Figura 45. Fornecimento e montagem das armaduras pré-fabricadas (44 unidades)

Figura 46. Concretagem das brocas, contrapiso e laje pelos próprios moradores (44 unidades)

Figura 47. Moradores do assentamento Dona Carmem trabalhando na construção das suas próprias casas

Figura 48. Varanda Antiga da sede da fazenda Bela Aliança (Bofete/ SP. 1948)

Figura 49. Cozinha e varanda de casa rural.

Figura 50. Banheiro localizado na parte externa (esquerda) e interna direita) da casa.

Figura 51. Mudanças no exterior e cozinha na moradia rural.

Figura 52. Especificaços mínimas para mobiliário - PNHR/PMCMV

Fig 53. Comprivo (en)

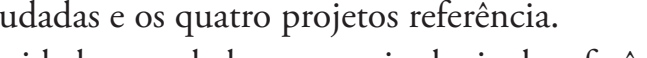

Tigura 55. Clogia de referência

Figura 56. Estudo mofó́

Figura 56. Estudo moffologico de flexibilidade do projeto construido (lote 21) do contrato das 120 casas

Figura 57. Estudo morfologico de flexibilidade do projeto construído (lote 135) do contrato das 44 casas

Figura 58. Estudo morfologico de flexibilidade do projeto construído (lote 135) do contrato das 27 casas

Figura 59. Estudo morfologico de flexibilidade do projeto construído (lote 158) do contrato das 10 casas

Figura 60. Programa com as áreas e as plantas do projeto aprovado e o projeto construído (L21) das 120 cas

Figura 61. Programa com as áreas e as plantas do projeto aprovado e o projeto construído (L135) das 44 casas

\section{Lista de Tabelas}

Tabela 01. Comparativo do número e área de estabelecimentos com área de até 100 ha. Brasil, (1950 a 2017) 29 Tabela 02. Estabelecimentos definidos na Lei $11.326 / 2006$ como da agricultura familiar e pessoal ocupado (2006) 30 Tabela 03. Valores destinados à habitacáo rural nos diferentes programas do Governo Federal e estado de SP Tabela 04. Tipologia de munícipios do PlanHab e número de munícipios em cada tipo.

Tabela 05. Metas quantitativas (unidades e investimento) por fases, faixas de renda e modalidades

Tabela 06. Valores destinados a habitaçăo rural no programa PNHR/MCMV

Tabela 07. Contrataçóes do PNHR por segmento - Sáo Paulo e Brasil

Tabela 08. Unidades contratadas do PNHR no estado de São Paulo (até 2018 — por Entidade Organizadora).

Tabela 09. Produçáo habitacional nas areas rurais da Empresa C

Tabela 10. Comparativo de áreas das unidades estudadas e projetos de referência em $\mathrm{m}^{2}$ 


\section{Lista de Siglas}

ABNT - Associação Brasileira de Normas Técnicas

BNH - Banco Nacional da Habitação Programa Carta de Crédito

ARPRAFF - Associação Retiro dos Produtores Rural do Assentamento Florestan Fernandes APRUP — Associação dos Produtores Rurais de Pacaembu

AT - Assessoria Técnica

BNH - Banco Nacional de Habitação

CADMUT - Cadastro Nacional de Mutuário

CC-FGTS - Programa Carta de Crédito FGTS

CDHU - Companhia de Desenvolvimento Urbano do Estado de São Paulo

$\mathrm{CEF}$ - Caixa Econômica Federal

COOPERHAF - Cooperativa de Habitação dos Agricultores Familiares

CONTAG - Confederação Nacional dos Trabalhadores na Agricultura

COOPMAPAAI - Cooperativa Mista dos Agricultores, Pescadores, Aquicultores e Apicultores

COOPPAF - Cooperativa de Pescador e Produtor da Agricultura Familiar

CRE - Comissão de Representantes

EO - Entidade Organizador

FDS — Fundo de Desenvolvimento Social

FETAESP — Federação dos Trabalhadores na Agricultura do Estado de São Paulo

FETRAF - Federação dos Trabalhadores e Troblhadoras na Agricultura Familiar

FGTS - Fundo de Garantia do Tempo de Serviço

GIHAB - Gerencia Executiva de Habitação da Caixa

HABIS — Grupo de Pesquisa em Habitaçăo e Sustentabilidade

IAU - Instituto de Arquitetura e Urbanismo

IBGE - Instituto Brasileiro de Geografia e Estatística

IBGE - Instituto Brasileiro de Geografia e Estatística

INCRA — Instituto Nacional de Colonização e Reforma Agrária

ITESP — Fundaçăo Instituto de Terras do Estado de São Paulo "José Gomes da Silvà"

MCidades - Ministério das Cidades

MDA — Ministério do Desenvolvimento Agrário

MPA — Movimento dos Pequenos Agricultores

MST — Movimento dos Trabalhadores Rurais Sem Terra
NBR — Norma Brasileira

OC - Operações Coletivas

OGU — Orçamento Geral da Uniáo

OP — Operações Parcerias

PA — Projeto de Assentamento de Reforma Agrária

PBQP-H — Programa Brasileiro de Qualidade e Produtividade do Habitat

PIB - Produto Interno Bruto

PLHIS - Planos Locais de Habitação de Interesse Socia

PMCMV — Programa Minha Casa Minha Vida

PNCF — Programa Nacional de Crédito Fundiário

PNHR — Programa Nacional de Habitação Rural

PNRA — Programa Nacional da Reforma Agrária

PSH — Programa de Subsídio à Habitaçăo de Interesse Social

PSH-Rural — Programa de Subsídio Habitacional Rural

RA - Região Administrativa

SFH — Sistema Financeiro de Habitação

SINTRAF — Sindicatos dos Trabalhadores na Agricultura Familiar

SUHAR — Superintendência de Habitação Rural da Caixa

TS - Trabalho Social

TTS - Trabalho Técnico Social

UFRN - Universidade Federal do Rio Grande do Norte

USP — Universidade de São Paulo 
1. Caracterização do campesinato brasileiro na atualidade

10. A posiçăo do campesinato, uma nova força de trabalho ou a preservação da sua

2. A terra: articulaçóes e contradiçóes na produçáo de morad ina

CAPÍTULO III | O projeto e a construção da autonomia

3. Programas de provisão de habitaçăo social para o campesinato brasileiro

3.1. O PNHR no Minha Casa Minha Vida

3.2. Produçấo recente do PNHR no estado de São Paulo

3.3. Arcabouço institucional do programa

4. Construçẫo da pesquisa

4.1. Hipóteses e objetivos da tese

4.2. Sobre o Método

4.3. Tratamento dos dados e ferramentas analíicas

4.4. Organizaçáo da tese

11. A casa camponesa brasileira

11.1. A moradia rural hoje

12. Projeto concebido: inadequação do padrão PMCMV

12.1. O PNHR - especificaçóes mínimas

13. Projeto executado: adequação e adaptaçăo da moradia

\section{| Considerações finais}

$\begin{array}{lr}\text { Considerações finais } & 227 \\ \text { 15. Uma nova forma de produçáo de casa camponesa? } & 228\end{array}$

1. Os agentes envolvidos na forma de produçáo da casa camponesa

15.1.1. O trabalho direto no canteiro de obras

5.1.2. Controle técnico da produção

5.1.3. Controle econômico direto da produçáo

15.1.4. Controle econômico indireto da produçáo

5. Funcionamento e gestáo da produçấo habitacional: projeto e obr

5.1. Regimes produtivos nos programas de moradia rural

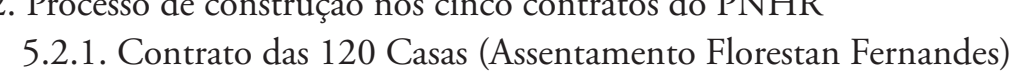

5.2.2. Contrato das 44 Casas (Assentamento Florestan Fernandes)

5.2.3. Contrato das 26 casas (Assentamento Boa Esperança) 5.2.4. Contrato das 27 casas (Assentamento Dona Carmem)
5.2.5. Contrato das 10 casas (Assentamento Dona Carmem)

5.2. Projeto e Canteiro

6. As EOs e o lugar da empresa construtora

novos rumos

7. A subempreitada e a terceirização

CAPÍTULO II | A tecnologia e o canteiro

8. limitaçóes que influenciaram o processo construtivo

8.1. O canteiro de obras disperso

8.2. Infraestrutura para a produçáo habitacional

9. A persistência da manufatura frente à racionalizaçăo dos processos

Referências bibliográficas e anexos

17. Referências Bibliográficas

18. Anexos

18.1. Roteiro de entrevistas semiestruturadas 


\section{Apresentação}

A presente tese, resultado da pesquisa de doutorado intitulada "Habitaçáo Camponesa: entre o projeto e a produçáo no PNHR", se insere no contexto das pesquisas relacionadas à provisão de habitaçáo social no campo brasileiro, mais especificamente no debate relacionado às dinâmicas e aos conflitos no processo de produção da moradia camponesa promovida pelo Estado nos assentamentos de reforma agrária da Região do Oeste do estado de Sáo Paulo.

O processo de produção é entendido a partir do encontro de duas dimensōes: por um lado, as políticas e os programas voltados para a provisão de habitaçáo no meio rural e, por outro, o modo de vida camponês, especificamente, um sujeito com múltiplas carências que se organiza em torno de uma questão - dentre muitas outras -, a procura de moradia. A intersecçáo destes campos apresentou diferentes questionamentos, por exemplo, como e qual tipo de moradia está sendo construída ou quanto vem sendo efetivado o direito à moradia neste contexto de divergência entre o que é predeterminado pelo Programa Nacional de Habitação Rural (PNHR), e o que realmente se faz necessário para a constituiçáo das condiçôes de produção de uma casa camponesa digna.

Apesar de ser considerada uma importante conquista pelos movimentos sociais rurais, a produção da habitação no campo, nas águas e nas florestas, especificamente para a populaçấo mais carente, ainda é considerada uma questáo secundária nas políticas públicas. O 
Programa Nacional de Habitaçáo Rural (PNHR), gerenciado inicialmente pelo Ministério do Desenvolvimento Agrário (MDA), foi absorvido pelo Programa Minha Casa Minha Vida, o que o tornou, assim, em apenas um subprograma sob a responsabilidade do Ministério das Cidades. Não precisamos ir muito a fundo para perceber que não existe uma política clara de habitação social rural, articulada a políticas de desenvolvimento social e autodeterminada em termos políticos e econômicos, independente da dimensão urbana. Desta forma, acaba sendo induzida, ainda que indiretamente, por algumas das principais contradiçôes do PMCMV, e reforçada pela concepção dicotômica, que termina dissociando as já complexas relaçōes entre o campo e a cidade.

Em termos práticos, o PNHR, formatado na lógica de produçáo habitacional do Programa Minha Casa Minha Vida, acaba herdando processos produtivos e tipologias arquitetônicas conservadoras, de racionalidade urbana e altamente padronizadas, claramente inadequadas ao modo de vida camponês, padrōes produtivos e relaçôes capitalistas que terminam se sobrepondo às condiçōes destas comunidades rurais.

O presente texto busca discutir, entáo, os diferentes aspectos da consolidaçấo destes novos processos de produção habitacional camponesa no âmbito do Programa Nacional de Habitação Rura (PNHR), procurando estabelecer relaçoes entre a produçáo da habitaçáo e do habitat camponês e as contradiçóes decorrentes da propriedade da terra. Para tanto, inicio pela caracterizaçáo do campesinato brasileiro hoje, sua relação política e administrativa com a cidade e a produçáo do espaço, refletindo sobre seu lugar e sua indiscutível presença na sociedade brasileira. Num segundo momento, a relaçấo da propriedade da terra e a produçáo de moradia nestes territórios, refletindo a respeito das articulaçóes, bem como as contradiçôes da inviabilidade de capitalizaçáo da renda fundiária nos assentamentos de reforma agrária. E, finalmente, o debate a respeito dos avanços e retrocessos dos programas de provisão de habitaçáo social para o campesinato brasileiro, especialmente a formataçáo, o arranjo institucional e a produçáo do Programa Nacional de Habitaçáo Rural (PNHR).

Além desta análise fundamentada na literatura, este texto expóe, como objeto empírico, cinco empreendimentos habitacionais ocorridos em três diferentes assentamentos rurais do estado de Sáo Paulo: Assentamento Florestan Fernandes (Mirandópolis), Assentamento Boa esperança (Pacaembu) e Assentamento Dona Carmem (Mirante do Paranapanema). Nesta etapa, a simultaneidade entre observaçáo em campo e pesquisa teórica evidenciaram várias questôes, as quais são estruturadas nos itens seguintes. A primeira parte procura analisar o funcionamento, a articulaçáo e as dinâmicas da estrutura de provisăo habitacional do PNHR, categorizando os diferentes agentes que atuam nos processos construtivos e de gestão das casas; na segunda parte, pretende-se compreender o processo de produçấo em canteiro, mostrando as condiçōes do lugar, a incompatibilidade com as diferentes realidades do campo e a posiçáo do trabalhador neste contexto; finalmente, na terceira parte, é retomada a abordagem do projeto, a evidente inadequaçáo entre programa habitacional e modo de vida camponês e sua relação com o processo produtivo. 


\section{Caracterização do campesinato brasileiro} na atualidade

1. Hoje encontramos no país uma maior preocupaçáo respeito da qualidade de vida nas as urbanas do que aquelas que de 2017, a provisāo de serviços basicos na maioria das habitaçós rurais foi consideravelmen Segundo que nas areas urbanas. de América Latina y El Caribe CEAL, (2018, p. 24), no Brasil $24,3 \%$ das famílias em área rurais carecem de água potáve das habitaçōes rurais carecem de sistema de tratamento de esgoto enquanto 31,6\% na área urbana.

2. Este debate da contraposiçâa entre o rural e o urbano, segundo
Delgado (2005), comeca Delgado (2005), começa a

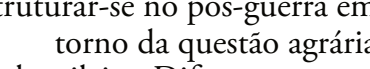
brasileira. Diferententes atores políticos e sociais formularam
cificuldade no desenvolviment industrial capitalista em face do posicionamento respaldou a classe latifundiaria tradicional a partir ecuária restrita às

médias propriedades brasileira (DELGADO, 2005)
É inegável a predominância do rural no cenário atual. Um espaço com uma crescente complexidade que se manifesta em suas estruturas sociais, econômicas, políticas, produtivas e territoriais. Porém, no campo teórico e prático aplicado ao ordenamento físico do território, o rural tem sido associado a uma concepçáo genérica de espaço vazio, espaço residual ou inútil, qualificando o solo rural como aquilo que fica do espaço ocupado, sobre o qual existe interesse imobiliário, passível de ser ordenado ${ }^{1}$ (PUELLO, 2005, p. 45). Desta forma, as açôes para o desenvolvimento rural tomaram quase sempre orientaçôes para combater a pobreza, mas, sem fazer parte de uma estratégia articulada de construção de sociedade. É frequente a criação de medidas parciais e descontínuas, desconsiderando a situação econômica e de exclusão social das populaçóes rurais mais pobres, fato que explica sua aparição e desapariçăo em funçăo dos ciclos ideológicos, políticos e econômicos (PÉREZ, et, al, 2009, p. 3)

A situaçáo anteriormente esboçada encontra sustento nas afirmaçóes de que o Brasil é um país urbano, as quais tomam como referência os resultados estatísticos do Censo Demográfico de 2010, que indica que $84,36 \%$ da população do país vive nas cidades. De fato, é uma realidade que faz muito tempo que a populaçăo das cidades brasileiras superou a rural $^{2}$, porém, é necessário relativizar esses porcentuais para além dos estudos estatísticos tipicamente urbanos. Contudo, em princípio, parece-nos mais importante colocar no centro do debate a noçáo do que efetivamente vem sendo estabelecido como a cidade e seus limites
- e, consequentemente, o rural como "resíduo" -, além das disputas quanto às concepçôes e posiçôes sobre a estrutura fundiária vigente no país e as políticas de distribuição de terra, sobre a produção do espaço e a produçáo agropastoril.

Como veremos, os princípios sobre os quais é definida a divisão das áreas rurais e urbanas do país têm suas origens no Decreto-Lei no 311 de 1938, do governo de Getúlio Vargas. Essa condiçấo oficial de "cidade" seria atribuída a todas as sedes municipais existentes, sem importar suas características espaciais, demográficas, econômicas e funcionais (VALADARES, 2014, p.8; ZUQUIM, 2008, p.3). A falta de clareza na adoçấo destes critérios implicam, em primeiro lugar, inclusão dos habitantes de municípios de pequeno porte à populaçáo urbana, 70,33\% (3.914 municípios) dos 5.565 municípios do país possuem uma populaçáo inferior a $20 \mathrm{mil}^{\text {pessoas }}{ }^{3}$, assim como densidades demográficas inferiores para serem considerados como urbanos.

As evidentes consequências desta concepçáa, que configura os espaços urbanos e rurais do pais - ainda vigente - se intensificam, uma vez que, após a Constituição de 1946, a atribuicăa de definir os limites do perímetro urbano ficou sob a responsabilidade das prefeituras e câmaras municipais, conceito aceito pelo IBGE (Instituto Brasileiro de Geografia e Estatística) no Censo de 20104. Desta forma, com plena autonomia, segundo Constituiçáo Federal no Artigo 30: cabe aos municípios a organizaçáo do seu território, o planejamento e controle do uso, do parcelamento e ocupaçáo do solo urbano. Além destas atribuiçóes, o próprio Estatuto da Cidade (Lei n. 10.257/2001, Art 41,
3. Sinopse do Censo Demográfico
2010. Disponivel em: <https:// www.ibge.gov.br/estatisticas/ sociais/rendimento-despesa-econsumo $/ 9662$-censo-demograficoAcesso em: 30 set. 2019.

4. Segundo a nota técnica do classificado pela localização. "Os domicílios de situaçáo urbana são aqueles localizados nas áreas
urbanas, que sáo as áreas intern ao perímetro urbano de uma cidade ou vila, definido por $\mathrm{Le}$ Municipal. As áreas urbanas sáo
classificadas em área urbanizad área não urbanizada e ́rézizadarbana isolada. Os domićílios de situação rural sáo aqueles localizados nas externa externas aos perimetros urbanos,
inclusive nos aglomerados rurais de extensão urbana, povoados, núcleos e outros aglomerados" 
I), estabelece que toda "cidade" com mais de 20 mil habitantes deve, obrigatoriamente, elaborar seu Plano Diretor.

Estas regras de caráter administrativo, orientadas a definir o perímetro urbano, também assumem um caráter econômico se consideramos que, quanto maior for a área urbana, maior a arrecadaçáo municipal. Por outo lado, Valadares $(2014$, p.12) ressalta que estas regras se tornam açōes de exclusão dos espaços rurais, já que estes ficam fora das áreas definidas pelo município para a implantaçáo das estratégias de desenvolvimento. Um exemplo que evidencia esta situação está contida no Art. 32 do Código Tributário Nacional, que define o município como ente responsável para cobrar o Imposto Predial Territorial Urbano (IPTU), desde que sejam atendidos pelo menos dois dos melhoramentos indicados na norma: 1) meio-fio ou calçamento, com canalizaçáo de águas pluviais; 2) abastecimento de água; 3) sistema de esgotos sanitários; 4) rede de iluminação pública, com ou sem posteamento para distribuiçấo domiciliar; e 5) escola primária ou posto de saúde a uma distância máxima de três quilômetros do imóvel considerado. Segundo o autor, esta exigência permite "constatar o quanto o acesso a serviços básicos e (...) a garantia de um nível mínimo de cidadania estáo estreitamente associados ao espaço urbano" (VALADARES, 2014, p.13)

Ainda sobre o caráter econômico, é responsabilidade da Secretaria da Receita Federal, em nome da Uniāo, arrecadar o ITR (Imposto Territorial Rural), devendo repassar 50\% aos municípios. Contudo, pode-se realizar convênios entre a uniáo e os municípios, sendo possível delegar a eles as diferentes atribuiçoos de arrecadaçấo e fiscalizaçấo das propriedades rurais, além de se beneficiar ao assumir este papel. Neste caso, segundo Silva (2014), percebe-se uma superposição de poderes e ainda uma disputa com dois entes legislando ao mesmo tempo sobre o território (rural e urbano).

Reduzir o problema apenas aos efeitos da delimitaçấo políticoadministrativa da cidade - definida a partir de critérios motivados mais pela tributação municipal do que pelo interesse de planejamento territorial - náo responde ao entendimento das contradiçóes decorrentes do processo de produçáo e reproduçáo da sociedade desse $99,37 \%{ }^{6}$ do território brasileiro. Desta forma, torna-se necessário abordar a questão da produção do espaço, já que os critérios adotados até hoje impedem de caracterizar o território que náo se encontra inserido na rede urbanizada, bem como a constituição de uma tipologia que retrate a diversidade territorial (ZUQUIM, 2008).

Segundo os resultados preliminares do Censo Agro do IBGE de 2017, $41 \%$ (350.253.329 hectares) do território nacional se constituem como estabelecimentos agropecuários, (5.073.324 propriedades). Desse total, 50.865 são imóveis rurais com área acima de 1.000 hectares (grandes proprietários) e, em contraste, 4.523 .693 são pequenas propriedades abaixo de 100 hectares. Isto quer dizer que, enquanto $1 \%$ dos estabelecimentos ocupam $47,52 \%$ das terras rurais com exploração agropecuária, outros $89,15 \%$ de estabelecimentos ocupam apenas $20,49 \%$ das terras, demonstrando o alto nível de concentração fundiária (ver figura 01), nas mấos de um pequeno número de pessoas. Situação ainda mais alarmante se consideramos os estabelecimentos de até 10 hectares, que correspondem a 50,15\% do número de
6. Este dado faz parte do estudo cito pela Embrapa Gestáo Territorial, que utilizou a base Demográfico de 2010 realizado pelo IBGE, integrado a um Sistema de Informaçáo Geográicica
por meio do software ArcGIS por meio do software ArcGIS (entre outros resultados) que a superficie ocupada pelas áreas
urbanas é é $0,63 \%$ do território urasileiro. É importante ressaltar que este estudo questiona a definiçáo das áreas urbana e rural nos estudos demográficos do legal do perímetro urbano de cad município. De acordo com geógrafo André Rodrigo Farias, analista da Embrapa e princip autor do trabalho, "parte das
inconsistencias verificadas pode estar relacionada com a próprì definiçáo de situaçáa ur anteriormente apresentada, um anteriormente apresentada, uma
vez que esta admite a inclusáo de áreas não urbanizadas na classificaçáo do setor censitário sejam internas ao perímetro urbano definido oficialmente po urbano definido oficialmente por
lei municipal" (FARIAS, et al.,
2017, p.3) 
propriedades, ocupando $2,28 \%$ do território com produção agropecuária.

Figura 01. Concentração
fundiária, Brasil $2017^{3}$

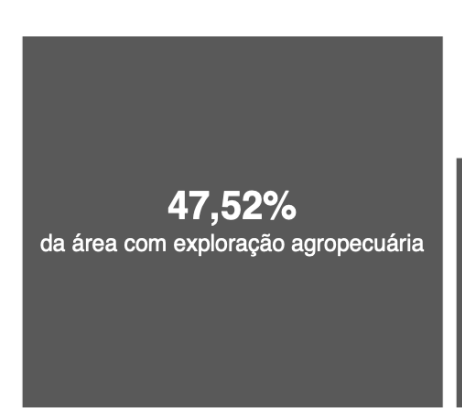

$1 \%$ das propriedades
umóveis com área acima de 1.000 ii

Fonte: Elaborado pelo autor.
Dados, Censo Agro do IBGE 2017. ${ }^{*} 1,55 \%$ faltante (mais de

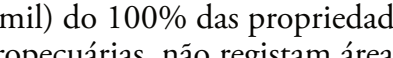
no censo.

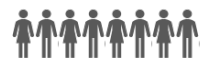

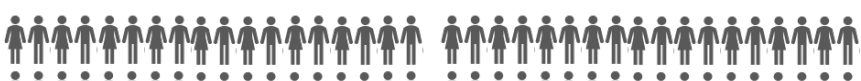

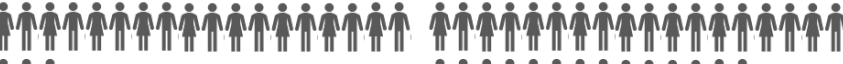

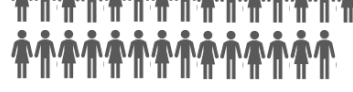

Se compararmos estes dados preliminares com o último censo agropecuário de 2006, percebemos que os estabelecimentos com área acima de 1.000 hectares passaram a ocupar $3,09 \%$ a mais de terra (19.895.040 hectares), evidenciando que na última década houve um aprofundamento da concentraçấo fundiária no país. Estas grandes extensōes de terras concentradas nas mãos dos grupos econômicos, que hoje somam 166.451.258 hectares, funcionam "ora como reserva de valor, ora como reserva patrimonial. Ou seja, como instrumento de garantia para o acesso ao sistema de financiamentos bancários, ou ao sistema de políticas de incentivos governamentais" (OLIVEIRA, 2007)
Como vimos, é indiscutível a expansão territorial do latifúndio no campo brasileiro, contudo, como ponto de partida desta pesquisa, adotamos a concepção que defende náo só a permanência, como também o aumento do campesinato na agricultura do país. Dados do censo agropecuário do IBGE evidenciam, em termos gerais, o aumento dos estabelecimentos de até 100 hectares de 1.725 .983 propriedades em 1950 até $4.523 .693 \mathrm{em} 2017$ (tabela 01). Um importante crescimento, porém, nota-se uma forte reduçáo em 1995 que, segundo Oliveira (2007, p.134), náo derivou apenas da crise da agricultura brasileira na década de 90 , mas sobretudo pelos processos derivados do crescimento da luta pela terra. número e área de
estabelecimentos com área de té 100 hectares. Brasil,

\begin{tabular}{lccccccc}
\hline \multirow{2}{*}{ Estabelecimentos } & \multicolumn{7}{c}{ Resultados dos censos IBGE de 1950 a 2017 } \\
\cline { 2 - 8 } & 1950 & 1960 & 1975 & \multicolumn{1}{c}{1985} & \multicolumn{1}{c}{1995} & \multicolumn{1}{c}{2006} & \multicolumn{1}{c}{2017} \\
\hline Número (unid.) & 1.725 .983 & 2.895 .899 & 4.501 .011 & 5.225 .162 & 4.318 .861 & 4.448 .648 & 4.523 .693 \\
\hline Área (hectares) & 37.213 .034 & 50.611 .458 & 69.154 .277 & 79.551 .709 & 70.575 .779 & 70.329 .548 & 71.772 .460 \\
\hline
\end{tabular}

Nos 4.367.902 estabelecimentos de agricultura familiar ${ }^{7}$ aferidos no censo Agropecuário IBGE de 2006 (84,36\% do total), identificaram-se 12,3 milhôes de pessoas ocupadas, contrastando com apenas 4,2 milhôes de pessoas nos estabelecimentos náo familiares, o que corresponde a 25,62\% da mão de obra ocupada (tabela 02). Estes dados evidenciam a crescente importância das famílias camponesas na realidade brasileira, pois em uma área consideravelmente reduzida (24\% do total), comparada com os 253.577 .343 hectares dos estabelecimentos de caráter capitalista, há um predomínio do pessoal ocupado de origem familiar, com 74,38\% de mão de obra. Fonte: Censos Agropecuários
$1995-1996 ;$; 2006 e 2017
do IBGE

7. Conceito definido pela Lei $11.326 / 2006$, que estabelece as diretrizes para a formulaçāo da
Política Nacional da Agricultura Familiar e Empreendimentos Familiares Rurais. 
Tabela 02. Estabelecimentos
definidos na Lei $11.326 / 2006$

como da agricultura familiar

pessoal ocupado nos
estabelecimentos - Brasil - 2006

\begin{tabular}{|c|c|c|c|c|c|c|}
\hline Agricultura familiar & $\begin{array}{l}\text { Total de } \\
\text { estabelecimentos } \\
\text { agropecuários }\end{array}$ & $\%$ & Área total (ha) & $\%$ & $\begin{array}{c}\text { Pessoal } \\
\text { ocupado no } \\
\text { estabelecimento }\end{array}$ & $\%$ \\
\hline Agricultura familiar - Lei $n^{\circ} 11.326$ & 4.366.267 & $84.36 \%$ & 80.102 .694 & $24 \%$ & 12.323 .110 & $74.38 \%$ \\
\hline Não familiar & 809.369 & $15.64 \%$ & 253.577.343 & $76 \%$ & 4.245.095 & $25.62 \%$ \\
\hline Total & 5.175 .636 & $100 \%$ & 333.680 .037 & $100 \%$ & 16.568.205 & $100 \%$ \\
\hline
\end{tabular}

Fonte: Censo Agropecuário
IBGE de 2006 (editado pelo autor)

Estes camponeses, apesar de cultivarem em uma área menor, são responsáveis por garantirem grande parte dos alimentos que compóem a dieta da populaçẩo do país. Em 2006, a agricultura brasileira era responsável por $70 \%$ da produçáo nacional de feijāo, $87 \%$ da produçắo de mandioca, $34 \%$ do arroz, $46 \%$ do milho e ainda $38 \%$ do café. Detém também $58 \%$ do leite de vaca, $59 \%$ do rebanho suíno e $50 \%$ do plantel das aves. Assim, as pequenas propriedades familiares $(89,4 \%$ ou 3,9 milhôes de estabelecimentos familiares que declararam) foram responsáveis por $38 \%$ ( $\mathrm{R} \$ 54,5$ bilhôes) do valor da produçáo agropecuária, com predomínio do tipo vegetal, que gerou $71 \%$ do valor da produçáo da agricultura familiar.

Com os dados anteriormente expostos, procuramos exemplificar que o campesinato năo é - nem será - uma populaçáo insignificante na sociedade brasileira. Em termos gerais, esta populaçáo nâo apenas vem aumentando de modo expressivo, como vimos, mas, pese as dificuldades, a agricultura familiar vem mostrando um importante desempenho econômico. O II Plano Nacional de Reforma Agrária do governo Lula destacou que "em toda a década de 90 , a agricultura familiar teve aumento de produtividade (...) em 3,79\%, apesar de ter tido uma perda de renda real de 4,74\%. A agricultura patronal, no mesmo período, teve perda menor $(2,56 \%)$, mas aumentou a produçáo em apenas 2,60\%". Cabe destacar que, este desempenho aconteceu apenas com acesso ao $25,3 \%$ do crédito, comparado com o $73,8 \%$ da agricultura patronal.

No esforço de compreender o papel e lugar do campesinato na sociedade brasileira e as transformaçôes que vem sofrendo o campo sob o modo capitalista de produçáo, surgem diversas abordagens teóricas (enquadradas no pensamento marxista). Oliveira (2001; 2004; 2007) descreve três vertentes, as quais a partir das suas interpretaçốes e evidentes divergências repercutem nas principais questôes no campo brasileiro, principalmente nas relaçôes de produção que se dáo no território que, segundo Oliveira (2007, p.8), redefinem toda a estrutura socioeconômica e política no campo.

De forma geral, há duas vertentes que convergem na interpretação de que o camponês não tem lugar no futuro "desenvolvimento" do campo, pois, o processo de generalização de relaçóes de produção capitalista no interior da produçáo agrícola, tal como ocorre na indústria, conduziria inevitavelmente à homogeneização das relaçóes de produção, ou seja, uma sociedade capitalista composta por duas classes sociais: a classe burguesa e o proletariado (trabalhadores assalariados). Por final, a extinção das relaçóes não-capitalistas ${ }^{8}$ de produção.
8. Ver "Teoria dos sistemas econômicos náo capitalistas" de
Aleksandr Chayanov, (2014 [1924]), uma das mais completas entativas de teorizaçăo do comportan
camponês. 
9. Por exemplo, (dentre outros)
ver: ABRAMOVAY, Ricardo, "Paradigmas do Capitalism agrário em questäo", Hucitec, São
Paulo, 1992; KAUTSKY, Karl "A Questäa Agrária", Proposta Ed. Vladimir I. "O Desenvolvimento do Capitalismo na Rissia", Col. Os Economistas, Abril Cultural São Paulo, 1982
Na primeira vertente, este processo de generalizaçáo se daria por duas vias: 1) pela destruição do campesinato, estimulada pelas contradições próprias da sua integraçăo no mercado capitalista, este processo de diferenciação interna transformaria o produtor familiar em duas classes sociais, os pequenos capitalistas rurais e os camponeses empobrecidos que acabariam se proletarizando; 2) pela modernização do latifúndio, através da maquinaria e insumos e, consequentemente, sua transformação em empresa capitalista. Para estes autores ${ }^{9}$, as relaçōes não-capitalistas de produçáo são entendidas como resíduos, inevitavelmente em vias de extinçáo do plano econômico.

Um segundo grupo de autores partem do princípio de que há uma penetração das relaçóes capitalistas no campo. Nesta vertente, a coerção econômica e política tem um papel crucial no processo de desintegração das estruturas agrárias tradicionais. Este processo de separação acontece a partir de três fases: 1) a separação do pequeno produtor dos vínculos e hierarquias comunitárias tradicionais, sendo este (o camponês) individualizado; 2) nesta etapa, a partir da introduçáo à economia de mercado, produz-se a separaçâo da indústria rural e a agricultura; 3 ) agora, com o camponês integralmente inserido na economia de mercado, fica refém dos mecanismos econômicos. Isso o levaria ao endividamento, pois náo teria como competir com a superioridade técnica e econômica da produção em larga escala. Consequentemente, sem os meios de produçáo, o camponês se tornaria trabalhador assalariado.

Lopes et al. (2017) aponta que estas vertentes tomam como referência dados oficiais tipicamente urbanocêntricos, que consideram os espaços rurais e as relaçóes de produçáo vigentes neste meio em estado de transformaçáo e que, em um futuro próximo, o espaço rural não mais existirá - tudo será urbano. O arquiteto e urbanista Emilio Pradilla (2002) se posiciona a respeito deste tema, indicando que transformaçáo dos povos rurais é a expressão não da conformação de novas ruralidades, e sim da decomposição do campesinato pelo capital e pela cidade capitalista, e que, apesar de se encontrar territórios aparentemente com estruturas mais estáveis, sem grandes mudanças, também serão em algum momento reinseridos no mundo do capital. Autores que defendem o ponto de vista que associa o avanço da urbanizaçáo sobre o território rural terminam invisibilizando a populaçáo camponesa, tornando quase irrelevantes os problemas de planejamento e arquitetura nestes territórios - pois, ao final, deixarám de existir.

Recentemente, há cada vez mais estudiosos que veem o processo de desenvolvimento do capitalismo no campo de outra forma, entendendo o campesinato como dentro e náo fora do capitalismo, diferente das vertentes anteriormente vistas, considerando-o como classe social. Este grupo de teóricos tomam como referência o funcionamento do próprio modo de acumulação do capital. Oliveira $(2001 ; 2007)$ expôe que o processo de reproduçáo ampliada do capital, além de redefinir e subordinar relaçôes de produçáo especificamente capitalistas (trabalho assalariado, p.ex.: através da presença no campo do "boia-fria"), engendra, da mesma forma e contraditoriamente, relaçóes náocapitalistas (através da presença e do aumento do trabalho familiar camponês) necessárias à sua reproduçáo. 

ao contrário, o constante processo de acumulaçáo primitiva - feito através das relaçōes não-capitalistas -, necessário ao seu desenvolvimento (do capital), assegura a existência do trabalho familiar camponês.

Esta linha de pensamento contribui também para compreender a relaçáo entre o campo e a cidade, definida como uma unidade contraditória. Territórios unidos dialeticamente através do processo produtivo, conforme Lopes et al. (2017, p. 3) e Oliveira (2004, p. 32), uma unidade aonde a diferença entre as atividades econômicas (a agricultura, a pecuária e outros, em um, e a indústria, o comércio etc., em outro), é costurada permanentemente por relaçóes de trabalho antitéticas, encontrando, por exemplo, camponeses fazendo "bicos" na cidade - pela necessidade de se sustentar -e, ao mesmo tempo, processos de industrializaçáo de produtos agrícolas feitos no campo por trabalhadores da cidade. É preciso destacar que esta interpretação é fundamental para nós (arquitetos e planejadores), pois uma abordagem crítica da questáo da produção do habitat e da habitação no campo brasileiro deve partir da compreensão dos seus sujeitos (trabalhadores, sejam do campo ou da cidade) e de sua relevância histórica, social, política e econômica.

Se olharmos para a moradia social, elemento chave para a reprodução do campesinato, parece-nos evidente compreender as contradiçōes geradas pelo processo de desenvolvimento do capitalismo neste setor. Questóes presentes em outros aspectos da vida camponesa se tornam relevantes aqui, a hegemônica delimitaçáo urbanocêntrica do território, que acaba por simplificar a problemática do planejamento e da produçăo habitacional no campo brasileiro; a histórica invisibilidade das comunidades rurais que contrasta com sua relevância no cenário político e econômico do país e a posiçáo do campesinato frente aos permanentes processos de acumulaçáo.

\section{A terra: articulações e contradições na} produção de moradia

Historicamente, o acesso à terra - urbana e rural - sempre foi controlado pelos grupos econômicos dominantes, fato que tem incentivado a segregaçáo socioespacial no território, dificultando as camadas mais vulneráveis da sociedade ao acesso a melhores condiçóes de vida. Assim, na atualidade, em que as políticas públicas de tipo liberal se caracterizam por serem excludentes, a questáo da terra tem se tornado um meio na reestruturaçáo das dinâmicas de investimentos e arranjos do setor imobiliário da recente produçáo habitacional no país, assunto amplamente analisado no âmbito acadêmico, especialmente no que se refere ao Programa Minha Casa, Minha Vida (PMCMV).

Como uma das principais açốes para enfrentar a crise econômica mundial entre os anos 2007 e 2008 - a chamada crise das hipotecas subprime -, foi concebido pelo governo federal, em parceria com o setor imobiliário, um ambicioso programa habitacional, fundamentado em retomar a velha estratégia ${ }^{11}$ de dinamizar a economia através do fortalecimento do setor da construção civil. Neste caso, com a criação de uma política permanente, com fundos públicos e de novo sob o
11. A estratégia do programa
MCMV vem de uma heranç regime militar, na qual o Estado, com recursos públicos, incentivou as construtoras 
12. Um programa que ao

de interesse social voltado para

famílias de baixa rend

(denominada Faixa 1),

a famílias de mercado, destinaca

subdivide-se em duas faixas

(Faixa $2 \mathrm{e}$ Faixa 3 )
.

13. Criado pela Lei no 4.380 , de
21 de agosto de 1964, e extinto

através do Decreto-Lei no 2.291
de 21 de novembro de 1986.

discurso do "sonho da casa própria", o PMCMV veio não apenas como um conjunto de medidas econômicas, mas também foi apresentado como uma política social, ampliando consideravelmente a provisão de habitaçáo de interesse social, voltada para famílias de baixa renda ${ }^{12}$.

Após vários anos de funcionamento, não pode ser negado o sucesso quantitativo do PMCMV. Em apenas cinco anos, houve um vertiginoso crescimento na produçáo de moradias no país, contratando quase $80 \%$ das unidades financiadas pelo Banco Nacional de Habitaçáo (BNH), programa que em 22 anos $^{13}$ conseguiu produzir 4,5 milhôes de unidades habitacionais (AMORE, 2015, p. 12). Após um ano do lançamento do Programa MCMV, a taxa de crescimento anual do PIB da construçáo civil brasileira já atingia $11 \%$ com um significativo crescimento em relaçáo a 2009, com 7,2\% (BARAVELLI, 2014, p. 10). Desta forma, o programa posicionou a construcáo civil como um dos pilares do desenvolvimento econômico do país.

A lógica capitalista que sustentou a produçấo habitacional do programa náo apenas impulsionou extraordinários fluxos de capital provenientes do setor imobiliário e sua centralizaçấo pelas empresas da construçáo civil, como também criou as condiçôes para o rearranjo do mercado imobiliário, mobilizando e reorganizando diferentes tipos de agentes (investidores, construtoras, proprietários de terras etc.). De acordo com Lúcia Zanin Shimbo (2016, p. 122), dentre este conjunto de agentes, são as empresas construtoras que ganharam relevância, atuando como o agente imobiliário que executa e faz a intermediação entre proprietários de terra, agentes financeiros e consumidores.
Assim, como ressalta a autora, a incorporadora e a empresa construtora fundidas numa mesma figura jurídica dão origem a um novo agente privado, que desempenha múltiplos papeis: executa a construção, comercializa as unidades habitacionais, articula o financiamento habitacional do cliente, captura recursos no mercado de capitais e compra terrenos, que posteriormente reserva, consolidando, assim, um banco de terras (SHIMBO, 2010, p.26). Esta concentração de terras se constitui, para estes agentes, como uma das principais estratégias para maximizar a extração de renda imobiliária.

Como já vimos, a moradia se constitui numa mercadoria complexa, pois, além de concentrar diversos tipos de capitais ${ }^{14}$ e agentes, sua produção depende, invariavelmente, do principal insumo: a terra. Neste sentido, Samuel Jaramillo (2009) em sua formulaçáo da teoria da renda do solo urbano estabelece uma diferença fundamental entre a terra urbana e a terra rural - sendo o campo brasileiro a base de nossa análise -, diferença relacionada à articulaçáo deste (o solo) com os processos produtivos e econômicos e a mobilidade que existe entre cada tipo de terra e o produto.

$\mathrm{O}$ autor destaca que a terra rural está ligada a um único processo de produçáo, a agricultura. Portanto, possui uma única articulaçáa, ao que chama articulaçáo simples da terra rural. Da mesma forma, a terra urbana se relaciona com outro processo produtivo, o da construçáa, que tem como produto a edificaçáo (o espaço construído). $\mathrm{O}$ autor denomina esta relação a articulação primária da terra urbana.

A principal diferença entre a propriedade da terra rural e da urbana se refere à relaçáo de mobilidade que há entre cada modalidade de terra e 
15. No Capítulo XLVI do Livro "Renda dos Terrenos para "Renda dos Terrenos para Preço do Solo", Marx aponta a renda da terra utilizada na da terra agrícola.

o produto. De um lado, "a articulação das terras agrícolas com os bens produzidos cessa imediatamente após o término do processo de produção: os bens sáo finalmente consumidos ou reprocessados" (JARAMILLO, 2009, p.95). Ou seja, a terra rural, não tem mais influência sobre o produto produzido, nem para sua comercializaçáo e nem para seu consumo. Em contraste, a terra urbana se relaciona durante toda a vida útil com o seu produto, a edificação, ocupando o solo por tempo indefinido após a produçáo. Assim, no caso urbano, além da relação (do solo) com a produção do bem imóvel (articulaçáo primária), a relaçáo indissociável entre a terra e o produto cria articulaçōes com processos econômicos e sociais, ou seja, de circulação e consumo, o que o autor denomina, articulação secundária da terra urbana. Consequentemente, a combinaçáo da articulaçáo primária e secundária da terra urbana conformam a chamada articulaçáo complexa.

Em princípio, as formulaçốes de Marx a respeito da renda da terra se concentram na propriedade rural utilizada para a agricultura ${ }^{15}$, elaboradas a partir das características fundiárias e econômicas da época, o que de fato pode tornar um tanto ambíguas as interpretaçóes para outro tipo de propósitos, como os estudos para o caso urbano, ou até mesmo para o rural brasileiro de hoje. Desta forma, a contribuiçáo de Samuel Jaramillo (2009) para compreender a complexidade da propriedade territorial urbana e os processos de produçáo implícitos traz para nós um insumo teórico fundamental. Contudo, nesta reflexão do autor, ainda percebemos uma interpretação da propriedade da terra rural (no capitalismo) ligada apenas à agricultura. Nesse contexto, cabe questionar se, com a entrada do PNHR/MCMV no campo, há uma condição dupla da terra rural, ou seja, o solo rural, além de ser sustento para a produçáo de alimentos, articula-se à rama capitalista da construçăo no processo de produçăo habitacional financiado pelo programa.

Seguindo esta linha de raciocínio, também pode ser encontrada uma articulaçáo no consumo e, em alguns casos, na circulaçáo deste bem. Esta característica, em conjunto com outras particularidades do meio rural, configuraria novos arranjos na produção habitacional no campo, os quais o PNHR náo consegue decifrar completamente - talvez por causa da sua própria concepçáo, fundamentalmente "urbana".

É importante dizer que, para a produçăo habitacional no meio rural, o PNHR não considera a terra como uma questấo central, diferente do PMCMV, no qual a terra, como já vimos, é transformada em mercadoria e até exerce o papel de reserva de valor. Isto quer dizer que o programa na modalidade rural não oferece auxílio para compra de terras, exigindo a propriedade da parcela. E, particularmente para acessar o recurso destinado à construção de habitaçăo social para as famílias beneficiárias do Programa Nacional de Reforma Agrária (PNRA), o beneficiário deve ter a posse da terra, ou seja, apenas o direito para trabalhar na sua parcela. Esta situaçăo evidencia o pouco interesse na questâo da luta pela terra, ou, melhor, a desconexão com a realidade fundiária do país, com um programa de provisão habitacional que limita sua atuaçáo a um processo eliminatório, dando prioridade a quem tem e, por conseguinte, excluindo a imensa maioria da populaçáo sem-terra. 
Certamente, a casa, considerada uma benfeitoria necessária para a produçáo camponesa, impacta de alguma forma o valor no mercado da pequena propriedade rural e, consequentemente, a dinâmica imobiliária. Porém, como já vimos, por causa da inviabilidade de capitalizaçáo da renda fundiária nos assentamentos de reforma agrária, percebemos diversas dificuldades de valorizaçăo da produçấo habitacional nestes territórios, o que de fato implica na reprodução de dinâmicas de um capitalismo primitivo, principalmente no que se refere à superexploraçáo do trabalhador, alteraçáo da posiçáo e funçóes exercidas pelas Entidades Organizadoras, empresas e demais agentes técnicos (AT e TTS) e até rebaixamento da qualidade das moradias produzidas. Estas dificuldades e outras seráo expostas ao longo do presente trabalho.

\section{Programas de provisão de habitação social} para o campesinato brasileiro

Esta parte da introdução se dedica a debater algumas consideraçóes a respeito dos avanços e retrocessos dos programas que surgiram a partir do início deste século para a provisão de habitaçáo para o campo brasileiro. Como veremos, estes programas não necessariamente apresentam formataçóes inteiramente novas, mas também encontra-se alguma continuidade em alguns dos seus pontos estruturais, tornando indispensável sua comparação.

Considerados por muito tempo como pequenos núcleos isolados do desenvolvimento das cidades, os agricultores em condiçôes mais vulneráveis tiveram um acesso muito restrito aos principais serviços públicos. Deste modo, o século passado, apesar de se mencionar na legislaçấo "a construçấo de moradia para a populaçăo rural" o setor sofreu a falta de programas habitacionais em que o trabalhador rural pudesse ser financiado para prover sua própria moradia (BOVO PERES, 2003). As políticas no setor rural estavam apenas concentradas na produção agropecuária e em preocupaçóes sociais para o controle sanitário, submetendo o campesinato a moldes pré-modernos, e atrasados do desenvolvimento e sem muitas opçóes de habitaçáo de qualidade. Pensada inicialmente para enfrentar os problemas habitacionais das faixas de população de baixa renda, a Fundação da Casa Popular passaria, com o Decreto-lei $\mathrm{N}^{\circ}$ 9.777, de 06 de setembro de 1946, a ter a possibilidade de atuar em áreas complementares como obras urbanísticas de abastecimento d'água, esgotos, suprimento de energia elétrica, assistência social e outras. E a novidade do decreto foi a introdução da habitação rural "nos aspectos de construção, reparação e melhoramento", como nova meta institucional.

II - financiar, na zona rural, a construçăo, reparaçăa, ou melhoramento de mas que atendam aos requistos mínimos de higiene conforto bem como mas que atendam aos requisitos minimos de higitene conforto, bem como
suprimento de energia elétrica (BRASIL, 1946).

A experiência se encarregaria de demonstrar, nos anos seguintes, quáo irrealistas e pretensiosas eram tais metas. Como atacar simultaneamente o problema da moradia popular no campo e na cidade e o da infraestrutura sanitária? Como dotar às prefeituras de pessoal qualificado e, ao mesmo tempo, realizar pesquisas e estudos que conduzissem ao barateamento de construçôes? (AZEVEDO E ANDRADE, 1982, p. 3). Quase duas décadas depois, a lei n.o 4 504, de 30 de novembro de 1964, que dispóe sobre o Estatuto da Terra, 
menciona no artigo 75 "[...] a elevaçáo do nível sanitário, através de serviços próprios de saúde, e saneamento rural, melhoria de habitaçáo e de capacitaçáo de lavradores e criadores, bem como de suas famílias [...]" (BRASIL, 1964). Esta é só uma pequena referência inserida numa ampla legislação, o que demostra o escasso interesse do Estado na soluçâo da problemática habitacional no campo.

Já em meados da década de 1990, segundo Rover e Munarini (2010, p. 262), é iniciado um conjunto de políticas no Brasil que procurava o desenvolvimento rural para além de seu caráter setorial produtivo, com a intenção de integrar atores, setores e açốes destinados a promover o desenvolvimento rural. Iniciativas que resultaram como insuficientes e que só começaram a ganhar força a partir da década seguinte. Cabe aclarar que o papel dos movimentos sociais é fundamental- não necessariamente pela iniciativa institucional - nos avanços na construçăo de novos espaços de participaçáo social e na procura de políticas mais adequadas para o desenvolvimento rural.

Operado inicialmente pelo INCRA desde 1985, o Crédito Instalação é um programa destinado a famílias assentadas da reforma agrária, baseado em diversas modalidades direcionadas a suprir as necessidades básicas e fortalecer as atividades produtivas ${ }^{16}$, o programa pretendia auxiliar na construção ou reforma de suas unidades habitacionais. Apesar desta tentativa, só a partir do início deste século que começou a dar forma a primeira iniciativa efetiva de financiamento público para produçáo de moradias no meio rural no país. No final do ano 2000, a Caixa Econômica Federal (CEF) e o INCRA celebraram um acordo de cooperaçáo e parceria para construçáo de habitaçoes nos Assentamentos de Reforma Agrária com recursos oriundos do Programa Carta de Crédito - FGTS (CC-FGTS), Operaçóes Coletivas - aquisiçăo de material de construção (SILVA, 2014, p. 86). Este programa fo reformulado em 2004 através da Resolução No 460 (BRASIL, 2004) do Conselho Curador do FGTS, com um novo modelo que possibilitou a formalização de novas operaçôes coletivas em parceria com uma Entidade Organizadora (EO) com recursos do OGU (Orçamento Geral da União), que se diferencia da Coletiva, pois a contrapartida da EO pode ser dada em bens ou serviços, como doaçáo de terrenos, infraestrutura ou prestaçáo de assistência técnica.

Após diversas negociaçóes entre o MST e o governo Lula, surgiu a proposta de elaboraçáo de um programa específico que atendesse à produção de novas unidades habitacionais no campo vinculado ao Projeto de Desenvolvimento de Assentamento (PDA), vislumbrando-se a possibilidade de pensar o assentamento como um todo. No entanto, optou-se em adaptar um programa existente que já atendia às demandas habitacionais da cidade, o Programa de Subsídio à Habitação de interesse social (PSH). Assim, este programa é ajustado para atender a populaçăo residente em assentamentos rurais.

De acordo com a Portaria Interministerial No 186, de 07 de agosto de 2003, o PSH tem por finalidade "[...] tornar acessível a moradia para os segmentos populacionais de renda familiar alcançados pelos programas de financiamentos habitacionais de interesse social" (BRASIL, 2003), via complementaçáo de subsídio de operaçōes de financiamento habitacional. Propóe o atendimento da populaçấo, tanto urbana como rural, destacando, nesta última, como diretriz a possibilidade da permanência do homem no campo. 
Em 2002, é iniciado o Programa de Subsídio de Habitaçáo Rural (PSH-Rural), inicialmente como projeto piloto de habitaçáo rural no Rio Grande do Sul, operado com recursos do Orçamento Geral da União (OGU) e do FGTS (SILVA, 2014, p. 86). Implantado em todo o país em 2003, o Programa de Subsídio de Habitação Rural (PSH Rural) foi resultado de uma articulação entre o INCRA, a CEF e o MST. Através de um termo de cooperação técnica, firma-se a parceria entre o Ministério das Cidades (MC) e o Ministério do Desenvolvimento Agrário (MDA), que decidiram garantir financiamento habitacional próprio para os trabalhadores rurais semterra e os pequenos agricultores brasileiros.

Esta nova versão do PSH-rural disponibilizava um valor de R\$ 7.500,00 por família, sendo R \$ 4.500,00 subsídio do Orçamento Geral da União (OGU) e R \$3.000,00 financiados (devendo ser pago pelo beneficiário dentro de 20 anos) através do Fundo de Garantia por Tempo de Serviço (FGTS), como mostrado na tabela 03, e funcionou até 2005, beneficiando 9.410 famílias camponesas no país.

É no ano de 2003 que o Governo Federal iniciou o Programa Nacional de Habitaçáo Rural (PNHR), que visava atender famílias com renda entre 1 e 3 salários mínimos, exigindo contrapartida dos beneficiários. A meta era atender 6.300 pequenos agricultores e beneficiários do programa de Reforma Agrária. Este programa reuniu três linhas de acessos recursos: I) o PSH-Rural, encaminhado para agricultores com renda até R \$ 465 mensais; II) a CC-FGTS - Operaçōes Coletivas, para agricultores com renda de até 1 salário mínimo (com subsídio de R\$
5.907) e de $\mathrm{R} \$ 930$ a R $\$ 1.500$ (com subsídio de $\mathrm{R} \$ 3.000$, e os restantes R\$ 6.000, financiados em até 96 meses), e; III) o Crédito Solidário - FDS (Fundo de Desenvolvimento Social), é somado às modalidades de contratação do PNHR em 2004, para agricultores organizados em cooperativas com renda de até 3 salários mínimos, (financiamento de $\mathrm{R} \$ 10.000$ para construçáo e $\mathrm{R} \$ 7.500$ para reforma). (SILVA, 2014, p. 88; ROVER; MUNARINI, 2010, p. 263).

Para o âmbito estadual, especificamente, no caso do estado de SP (recorte geográfico desta pesquisa), podem ser mencionados dois programas: de um lado, o Pró-Lar Rural, lançado em 2003 pelo Governo do Estado de São Paulo, através da Companhia de Desenvolvimento Habitacional e Urbano (CDHU), e em parceria com os municípios. O objetivo do programa é atender famílias de trabalhadores residentes na área rural ou que, de forma geral, estão ligados à atividade rural, além de famílias ocupantes de lotes em assentamentos rurais administrados pelo Instituto de Terras do Estado de São Paulo (ITESP) e pelo Instituto Nacional de Colonizaçáo e Reforma Agrária (INCRA) (ALMEIDA, 2008, p. 50). Com a política adotada, a CDHU não faz distinção entre a populaçáo alvo, mantendo uma relaçáo de igualdade entre o urbano e o rural, permitindo subsidiar habitaçôes a serem autoconstruídas pelos beneficiários em seus lotes rurais ou em conjuntos habitacionais nas áreas urbanas dos municípios.

De outro lado, o Programa Casa Paulista, que mediante a Deliberação Normativa No 007, de 20 de março de 2012, aprova a implantação do Programa Apoio Financeiro Complementar ao Programa Nacional de 
Habitaçáo Rural - PNHR, integrante do Programa Minha Casa Minha Vida - PMCMV, mediante concessão de contrapartida Tabela 03. Valores destinados à programas do Governo Federal financeira de R\$10.000,00, por unidade habitacional.

estado de São Paulo.

\begin{tabular}{|c|c|c|c|c|c|c|}
\hline Período & \multicolumn{2}{|c|}{ Programa /modalidade } & $\begin{array}{l}\text { Renda } \\
\text { limite rmf* } \\
\text { (R\$) }\end{array}$ & $\begin{array}{l}\text { valor disponível } \\
\text { (R\$) }\end{array}$ & $\begin{array}{l}\text { ISubsídio } \\
\text { (R\$) }\end{array}$ & $\begin{array}{l}\text { Contrapartida / } \\
\text { Financiamento (R\$) }\end{array}$ \\
\hline 2000-2001 & \multicolumn{2}{|c|}{ CC-FGTS Op. Coletivas } & Assentados & Até $\mathrm{R} \$ 2.500$ & Integral & - \\
\hline 2004-atual & \multicolumn{2}{|c|}{ CC-FGTS Op. Parcerias } & $\mathrm{R} \$ 1.200$ & té $\mathrm{R} \$ 7.000$ & $\mathrm{R} \$ 2.500 \mathrm{FGTS}$ & $\mathrm{R} \$ 4.500 \mathrm{OGU}$ \\
\hline 2002-2003 & \multicolumn{2}{|c|}{ PSH-Rural (Piloto) } & $\mathrm{R} \$ 240$ & & & \\
\hline 2003-2005 & \multicolumn{2}{|c|}{ PSH Rural } & $\mathrm{R} \$ 740$ & ${ }^{\top} \$ \$ 1.500$ & 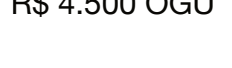 & (finan \\
\hline 2003-atual & \multicolumn{2}{|c|}{ Pró-Lar Rural (SP) } & 1 a $10 \mathrm{sm}^{\star *}$ & $\mathrm{R} \$ 8.000$ & - & $\mathrm{R} \$ 8.000$ \\
\hline 2012-atual & \multicolumn{2}{|c|}{ Casa Paulista (SP) } & Assentados & $\mathrm{R} \$ 10.000$ & Integral & - \\
\hline \multirow{4}{*}{ 2003-2009 } & \multirow{4}{*}{ PNHR } & CC-FGTS (Caução) & $1 \mathrm{sm}^{* *}$ & $\mathrm{R} \$ 8.000$ & $\mathrm{R} \$ 5.907$ & $\mathrm{R} \$ 2.093$ \\
\hline & & $\begin{array}{l}\text { CC-FGTS } \\
\text { (Financiamento) }\end{array}$ & $\mathrm{R} \$ 1.500$ & $R \$ 9.000$ & $\mathrm{R} \$ 3.000$ & $\mathrm{R} \$ 6.000$ \\
\hline & & PSH Rural & $\mathrm{R} \$ 465$ & Até $R \$ 4.500$ & Integral & - \\
\hline & & Crédito Solidário & $3 \mathrm{sm}^{* *}$ & Até $\mathrm{R} \$ 10.000$ & - & $\mathrm{R} \$ 10.000$ (financiado) \\
\hline
\end{tabular}

Fonte: Elaboraçäa própria a parti

de Lenzi (2017), Silva (2014)
Rover; Munarini (2010)

${ }^{*}$ rmf: renda mensal familiar, ${ }^{* *}$ sm salário mínimo.

\subsection{O PNHR no Minha Casa Minha Vida}

Alguns anos antes da implementação do Programa Minha Casa Minha Vida, o Ministério das Cidades preparava um conjunto de açōes para enfrentar o problema habitacional por meio da diversidade de programas e produtos definidos em funçáo da participaçáo popular e das características demográficas e das dinâmicas econômicas (AMORE,
2015, p. 17). Neste sentido, o PlanHab propóe formas distintas de atendimento a partir de 11 tipologias de municípios (tabela 04), classificadas, segundo Krause et al. (2013), a partir da faixa populacional, da inserçấo metropolitana, da polarizaçáo regional, das variáveis socioeconômicas e dos níveis de pobreza, entre outros fatores, destacando os 3.819 municípios com porte populacional de até $20 \mathrm{mil}$ (pequenas cidades em espaços rurais, tipos I, J e K), que concentra o maior déficit de habitação rural. Para estes municípios de pequeno porte e para as áreas rurais, foram definidos como produtos habitacionais: o lote urbanizado (nas áreas urbanas, por causa da disponibilidade de terra), somado a uma cesta de materiais (com ou sem mão de obra) e à assistência técnica no processo de produçáo.

Tabela 04. Tipologia de de munícipios em cada tipo.

\begin{tabular}{|c|c|c|}
\hline $\begin{array}{l}\begin{array}{l}\text { Faixa } \\
\text { populacional }\end{array} \\
\end{array}$ & Tipologia & $\begin{array}{l}\text { Número de } \\
\text { munícipios }\end{array}$ \\
\hline \multirow{5}{*}{$\begin{array}{l}\text { Mais de } 100 \\
\text { mil habitantes } \\
\text { e RMs }\end{array}$} & A. RMs do Rio de Janeiro e de São Paulo & 59 \\
\hline & B. Principais aglomerações e capitais ricas & 186 \\
\hline & C. Aglomerados e capitais prósperas do $\mathrm{N}$ e do $\mathrm{NE}$ & 63 \\
\hline & D. Aglomerados e centros regionais do Centro-Sul & 215 \\
\hline & E. Aglomerados e centros regionais do $\mathrm{N}$ e do $\mathrm{NE}$ & 58 \\
\hline \multirow{3}{*}{$\begin{array}{l}\text { De } 20 \text { mil a } \\
100 \text { mil } \\
\text { habitantes }\end{array}$} & F. Centros urbanos em espaços rurais prósperos & 250 \\
\hline & G. Centros urbanos em espaços rurais de média renda no Centro-Sul & 274 \\
\hline & H. Centros urbanos em espaços rurais com desigualdade e pobreza & 587 \\
\hline \multirow{3}{*}{$\begin{array}{l}\text { Menos de } 20 \\
\text { mil habitantes }\end{array}$} & I. Pequenas cidades em espaços rurais prósperos & 1.002 \\
\hline & J. Pequenas cidades em espaços rurais pobres, com baixo dinamismo & 1.453 \\
\hline & K. Pequenas cidades em espaços rurais pobres, com alto dinamismo & 1.417 \\
\hline Total & & 5.565 \\
\hline
\end{tabular}

Fonte: Krause et al. (2013).
Dados do PlanHab e MCidades 
Contudo, este arranjo de produção habitacional proposto pelo PlanHab foi ignorado. A interpretação simplista do problema da habitação num contexto de crise econômica somado ao enfraquecimento do Ministério das Cidades levou o governo a escolher pela proposta de produçáo de habitação em massa em benefício do setor imobiliário e da construçáo civil (AMORE, 2015, p. 16). Desta forma o governo federal lançou o Programa Habitacional Minha Casa Minha Vida (PMCMV), que em 2009 comportou como meta inicial a construção de um milháo de casas (urbanas e rurais) para famílias com renda de até 10 salários mínimos.

Esta meta proposta pelo programa é distribuída em três faixas de renda. Para famílias da Faixa I, com renda de até 3 salários mínimos, a meta era construir 400 mil unidades (40\%) através do Fundo de Arrendamento Residencial (FAR), do PMCMV-Entidades e do PNHR. Para a Faixa II, famílias com renda bruta de até 06 salários mínimos, a meta era construir 400 mil unidades (40\%). E, para a Faixa de renda III, o programa apontou atender famílias com renda bruta de até 10 salários mínimos, com a meta de construir 200 mil unidades habitacionais (20\%). Em sua segunda fase, além de aumentar a quantidade de habitaçôes (com mais de dois milhōes de moradias até 2014), inclui uma revisão das metas de cada faixa de renda, a Faixa I aumentou para 60\%, comparado com $40 \%$ da primeira fase (Quadro 05). Também é feita a revisão das especificaçôes mínimas como ampliação dos ambientes, a acessibilidade e acabamentos, entre outras.

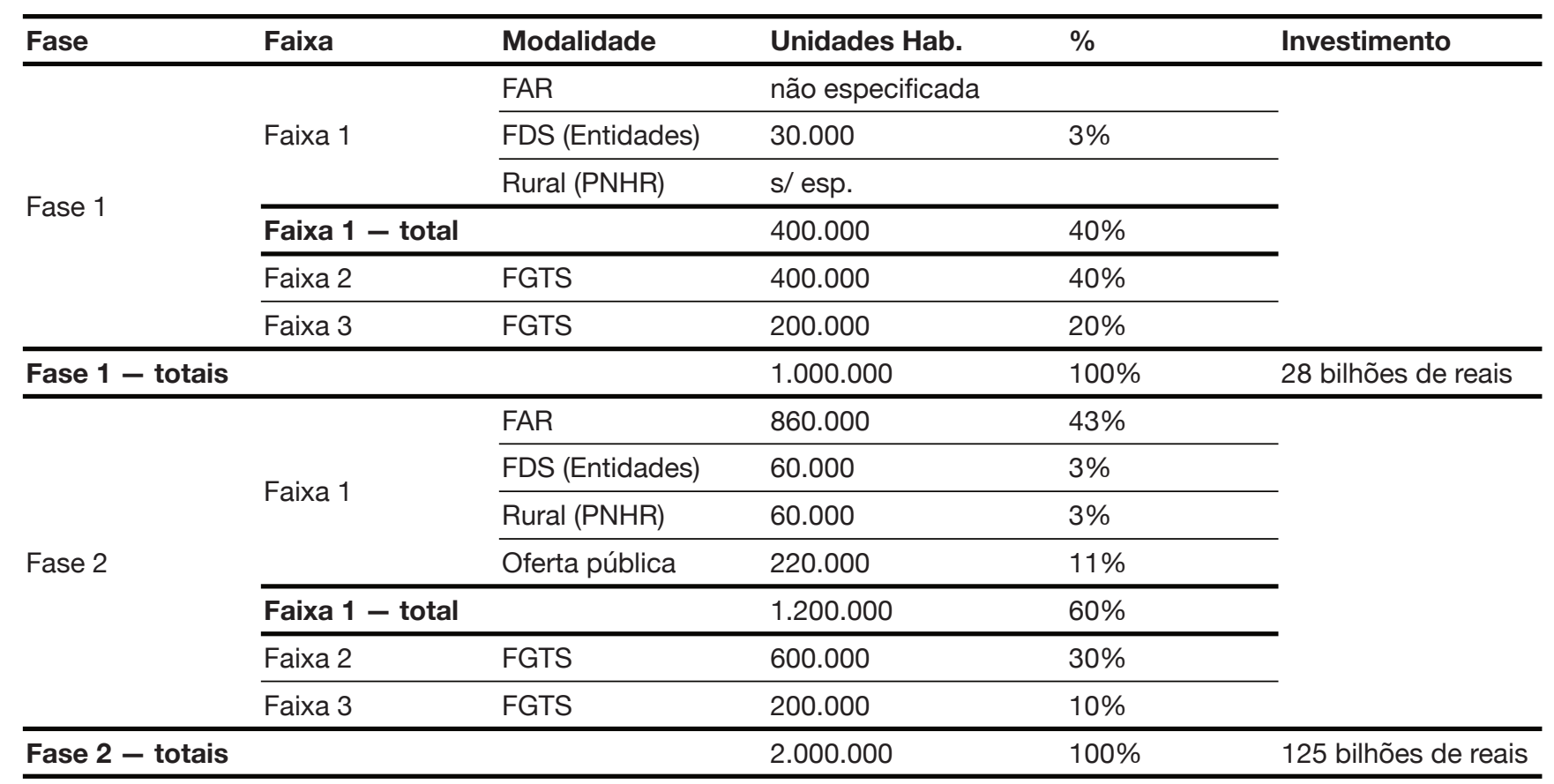

Apesar da quantidade de recursos financeiros (na forma de subsídios) destinados ao atendimento das famílias mais pobres (faixa 1 e 2), o programa tem recebido diversas $\operatorname{críticas}^{17}$ a respeito da segregação socioespacial ocasionada pelos empreendimentos, da especulação imobiliária, e do aprofundamento da confluência entre Estado, empresas construtoras, proprietários de terra e possuidores do capital financeiro, invertendo o que deveria ser uma política de caráter público para uma essencialmente de mercado. 
Com relação ao Programa Nacional de Habitaçáo Rural (PNHR), nas modalidades PSH Rural, CC-FGTS Operaçôes Coletivas e Crédito Solidário (FDS), estendeu-se até 2009, quando, através da Lei No 11.977, de 07 de julho de 2009, passou a integrar como subprograma (junto com o PNHU e PHPE) o Programa Minha Casa, Minha Vida (PMCMV). A Lei do PMCMV designa que o PNHR tem por finalidade "criar mecanismos de incentivo à produçâo ou reforma de habitaçóes rurais", para os agricultores familiares e trabalhadores rurais por intermédio de operaçōes de repasse de recursos do OGU ou de Figura 02. Linha de tempo dos programas habitacionais para o
campo - Brasil, período 1999 a financiamento habitacional com recursos do FGTS (SILVA, 2014, p 93).

can16.

GOV FHC (PSDB)

GOV. LULA (PT)

GOV DILMA (PT)

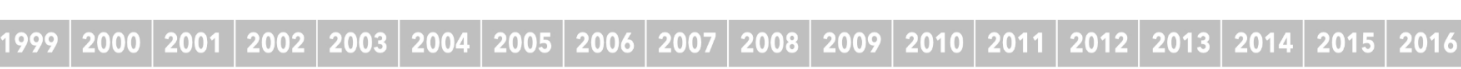
CRÉDITO INSTALAÇÃO

CC.FGTS OP. Coletivas - CEFINCRA

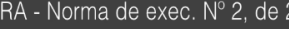

ch.

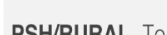

PNHR CC.FGTSPS

PMCMVPNHP

PNHRPNRA - do INCRAMDA para MC

PRÓ-LAR RURAL - CDHU (SP)

Fonte: Castańeda (2016, p.43), adaptado pelo auto:
Renda Bruta Anual Familiar de até R \$ 78.000,00 o Grupo 3 - G3, que recebe financiamentos de até $\mathrm{R} \$ 60.000,00$ a baixas taxas de juros; o programa atende também ao Grupo 2 - G2, para as famílias com renda bruta familiar anual até $\mathrm{R} \$ 33.000,00$ e; o Grupo 1 - G1 correspondente à menor faixa, abrangendo famílias com renda de até R\$ 17.000,00, comprovados por meio da Declaraçáo de Aptidão ao PRONAF, atendidas com subsídio a fundo perdido de $\mathrm{R} \$ 32.832,00$, oriundo do Orçamento Geral da Uniâo, e os outros $4 \%$ devem ser devolvidos em 4 parcelas anuis de $\mathrm{R} \$ 342,00$, totalizando R\$ 1.368,00. Estes beneficiários devem ser organizados de forma coletiva por EO de caráter público ou privado, em grupos de no mínimo quatro e no máximo cinquenta participantes. beneficiários do Programa sao agricultores familiares e Lei No 11.326, de 24 de julho de 2006, composto pelos:
silvicultores, que cultiven florestas nativas ou exóticas e que promovam o manejo sustentável daqueles ambientes, aquicul que explorem reservatón exerçam essa atividade artesanalmente; pescadores, que reşam a alvidade pesqueira integrantes de comunidades de quilombos rurais e demais povos L, 2006).

Tabela 06. Valores destinados a PNHR/MCMV
PNHR programa

\begin{tabular}{|c|c|c|c|c|c|c|}
\hline Período & Programa / $\mathrm{m}$ & dalidade & $\begin{array}{l}\text { Renda limite raf* } \\
(\mathrm{R} \$)\end{array}$ & $\begin{array}{l}\text { valor disponível } \\
(\mathrm{R} \$)\end{array}$ & Subsídio (R\$) & $\begin{array}{l}\text { Contrapartida / } \\
\text { Financiamento }(R \$)\end{array}$ \\
\hline \multirow{3}{*}{ 2009-atual } & \multirow{5}{*}{ PNHR MCMV } & G1 & $\mathrm{R} \$ 17.000$ & $R \$ 34.200$ & $R \$ 32.832$ & $\mathrm{R} \$ 1.368$ \\
\hline & & G2 & $\mathrm{R} \$ 33.000$ & $\mathrm{R} \$ 37.600$ & $\mathrm{R} \$ 7.600 \mathrm{FGTS}$ & Até $\mathrm{R} \$ 30.000$ \\
\hline & & G3 & $R \$ 78.000$ & $\mathrm{R} \$ 60.000$ & - & Até $R \$ 60.000$ \\
\hline \multirow{2}{*}{ 2013-atual } & & \multirow{2}{*}{$\begin{array}{l}\text { Assentados } \\
\text { PNRA }\end{array}$} & \multirow{2}{*}{$R \$ 15.000$} & $\mathrm{R} \$ 28.500^{* *}$ & \multirow{2}{*}{-Integral } & \multirow{2}{*}{-} \\
\hline & & & & $\mathrm{R} \$ 30.500^{\star \star \star *}$ & & \\
\hline
\end{tabular}

Vale a pena destacar que o subsídio para provisão de habitação rural é significativamente menor em relação aos valores disponibilizados par as cidades. Este rebaixamento de até $74 \%$ do valor do PNHR nấo se justifica, se considerarmos, por exemplo, as semelhanças em relação à faixa de renda das famílias, ao regime de produção e inclusive ao projeto arquitetônico e aos materiais com a modalidade MCMV-Entidades.
Fonte: Elaboraçáo própria a (2014). * *af: renda anual familiar, $*$ Nordeste, Centro-
Oeste, Sudeste e Sul, $* * *$ Norte
A meta prevista na segunda etapa do programa era de 120 mil unidades (entre construção e reforma), abrangendo um diverso grupo de beneficiários ${ }^{18}$, os quais estão divididos em três grupos (tabela 06 ), com 
Após algumas reformulaçoes no PMCMV, por meio da Portaria Interministerial $\mathrm{n}^{\circ} 78$, de 13 de fevereiro de 2013, os agricultores familiares beneficiários do Programa Nacional de Reforma Agrária (PNRA) são incluídos entre os possíveis beneficiários do Programa Nacional de Habitação Rural (PNHR), integrante do Programa Minha Casa, Minha Vida (PMCMV). A soluçáo de moradias nessas comunidades, que antes era responsabilidade do INCRA e do Ministério do Desenvolvimento Agrário (MDA), passou para o Ministério das Cidades. Assim, para as famílias com renda anual de até $\mathrm{R} \$ 15.000,00$ o programa disponibiliza subsídio de $\mathrm{R} \$ 28.500,00$ nas Regiốes Nordeste, Centro-Oeste, Sudeste e Sul e R \$ 30.500,00 na Regiâo Norte do país para construçấo, conforme a tabela 06 .

Neste contexto, um primeiro ponto se torna evidente: o aumento considerável do subsídio do novo formato do Programa Nacional de Habitação Rural (PNHR), em relação aos programas anteriores. Isto é considerado uma das principais conquistas pelos movimentos sociais que lutam por melhores condiçôes de moradia no campo. Se compararmos os valores da tabela 03 com a tabela 06 , percebemos que o subsídio a fundo perdido do Grupo 1 - G1 (PNHR/MCMV) de R\$ $32.832,00$ é mais de sete vezes maior do que o disponibilizado no PSH Rural (em todas suas versōes) e mais de cinco vezes maior do que o CCFGTS Caução do PNHR.

Outro aspecto para se ressaltar do PNHR/PMCMV, é a disponibilização de subsídio diferenciado de acordo com a região do país, garantindo maiores valores para a Regiāo Norte, em função de custos logísticos. Neste caso, o valor do subsídio para o $\mathrm{Gl}$ ficou estabelecido em $\mathrm{R} \$ 36.600,00$ para construçáo, e para os assentados rurais de $R$ \$30.500,00 nessa regiáo.

\subsection{Produçáo recente do PNHR no estado de Sáo Paulo}

Com relaçáo ao PNHR, apesar de não ter cifras táo expressivas em termos de recursos ou unidades produzidas, se comparadas com as cidades, este programa de provisão habitacional produz um impacto considerável no território, passível de ser estudado. Segundo o levantamento de Favareto et al (2019, p.65), entre 2009 e 2018, foram contratadas 215,7 mil (figura 03) e conclúdas 162,9 mil moradias, distribuídas em 2.700 dos 5.570 municípios brasileiros, em contratos que totalizam R \$ 6,1 bilhôes. No entanto, o PNHR representa apenas $11,7 \%$ das moradias contratadas da Faixa 1 do PMCMV e 6,6\% do total dos recursos disponibilizados para esta modalidade. E em relação ao total do PMCMV (Faixas 1,1.5, 2, e 3), representa 2,2\% das moradias contratadas e $0,8 \%$ do total dos recursos.

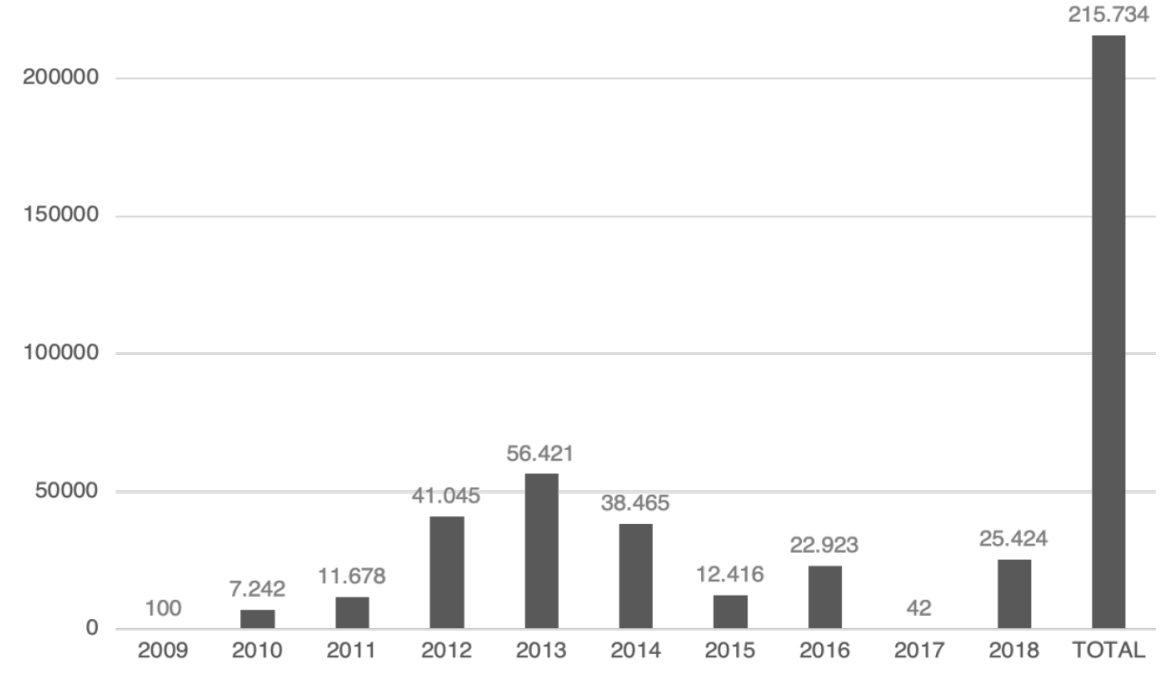

Figura 03. Unidades contratad

Fonte: Favareto et al (2019, p.68). Dados de relatórios da Caixa Econômica Federal e da 
De outro lado, percebe-se uma predominância no atendimento por segmento, com 59,6\% das unidades contratadas para os agricultores familiares, seguido dos trabalhadores rurais com 10,6\%. Apesar de colocar como meta a construçáo de 70.000 unidades para os assentamentos do Plano Nacional da Reforma Agrária, o programa penas contratou 16.615 unidades ou $7,7 \%$ para os assentados do PNHR por segmento - São PNRA (tabela 07).

\begin{tabular}{lllll}
\hline \multirow{2}{*}{ Tipo de beneficiário } & \multicolumn{3}{l}{ SÃO PAULO } & \multicolumn{3}{l}{ BRASIL } \\
\cline { 2 - 5 } & $\mathbf{N}^{\circ}$ UH & $\%$ & $\mathbf{N}^{\circ}$ UH & $\%$ \\
\hline PNCF - Prog. Nac. de Crédito Fundiário & 48 & $1.00 \%$ & 206 & $0.10 \%$ \\
\hline Pescadores Artesanais & 0 & $0.00 \%$ & 1272 & $0.60 \%$ \\
\hline Extrativista & 0 & $0.00 \%$ & 2119 & $1.00 \%$ \\
\hline Indígenas & 13 & $0.30 \%$ & 7567 & $3.50 \%$ \\
\hline Assentados do PNRAIINCRA & 937 & $19.30 \%$ & 16615 & $7.70 \%$ \\
\hline Outras comunidades & 0 & $0.00 \%$ & 16200 & $7.50 \%$ \\
\hline Quilombolas & 212 & $4.40 \%$ & 20385 & $9.40 \%$ \\
\hline Trabalhadores rurais e demais & 89 & $1.80 \%$ & 22857 & $10.60 \%$ \\
\hline Agricultores familiares & 3556 & $73.20 \%$ & 128513 & $59.60 \%$ \\
\hline Total & $\mathbf{4 8 5 5}$ & $\mathbf{1 0 0 . 0 0 \%}$ & $\mathbf{2 1 5 7 3 4}$ & $\mathbf{1 0 0 . 0 0 \%}$ \\
\hline
\end{tabular}

Fonte: Favareto et al (2019,
p.68). Dados de relatórios d

Caixa Econômica Federal e

No estado de Sáo Paulo, o PNHR financiou a construçáo de 4855 unidades habitacionais até 2018, ou seja, 2,25\% da produçáo habitacional PNHR no Brasil todo (215.734 UH). A partir da tabela 08, é possível observar que a Cooperativa de Habitaçáo da Agricultura Familiar do Estado de São Paulo e a Federação dos Trabalhadores da Agricultura Familiar do Estado de São Paulo (FETAESP) são as responsáveis pelo maior número de unidades contratadas no estado.
Tabela 08. Unidades contratadas Paulo (até 2018 - por Entidade

Entidades Organizadoras (EOs) que atuam em SP

Unidades

COOPERATIVA DE HABITAÇÃO DA AGRICULTURA FAMILIAR DO ESTADO DE SP FEDERAÇ̃̃O DOS TRAB. DA AGRIC. FAMILIAR DO ESTADO DE SP

OUTRAS

作

FEDERAÇÃO DOS TRABALHADORES NA AGRICULTURA EST SAO PAULO

COOPERATIVA DOS AGRICULTORES FAMILIARES E EMPREENDEDORES FAM

ASSOCIAÇÃO DE PRODUTORES NOVA CONQUISTA MUN. MIRANTE DO PARAN. ASSOC. COMUNITÁRIA REGIONAL DE AÇÃOO SOCIAL HEBERT DE SOUZA ASSOCIAÇÃO DE COOPERAÇÃO AGROECOLÓGICA DO ESTADO DE SÃO PAUL COOPERATIVA DE PESCADORES E PRODUTORES DA AGRICULTURA FAMI I ORGANIZAÇÃO DAS MULHERES UNIDAS DO SETOR II DA GLEBA XV DE N

ASSOCIAÇÃO DOS PRODUTORES RURAIS DO ASSENTAMENTO NOSSA SENHORA ASSOCIACCÃO DOS PRODUTORES DE MUDAS E SEMENTES DA CERB

ASSOCIAÇÃO ENTRE AMIGOS - ASSENTRA

ASSOCIAC̄ÃO TERRA E VIDA

ASSOCIAÇ̃̃O ORIENTE DE PRODUTORES RURAIS DO ASSENTAMENTO PRIM

ASSOCIAÇÃO BENEFICENTE DE INTEGRAÇÃO DISCIPULADO E EVANGEL

ASSOCIACC̃OO DOS PRODUTORES RURAIS DO ASSENTAMENTO ÁGUA BRANCA

ASSOCIACÃO DOS PRODUTORES RURAIS DO ASSENTAMENTO ESTADUAL SA

ASSOCIAÇÃO DAS PEQUENAS PRODUTORAS RURAIS BRAVAS GUERREIRAS

SOCIEDADE AMIGOS DO PARQUE ESMERALDA

ASSOCIAÇÃO DOS PRODUTORES RURAIS DO PROJETO DE ASSENTAMENTO TOTAL

\begin{tabular}{|r|r}
\hline & $\begin{array}{r}\text { Unidades } \\
\text { contratadas }\end{array}$ \\
\hline & 2259 \\
\hline & 1362 \\
\hline & 238 \\
\hline N. & 206 \\
\hline & 165 \\
\hline & 120 \\
\hline & 91 \\
\hline & 55 \\
\hline & 55 \\
\hline & 55 \\
\hline ORA & 38 \\
\hline A & 36 \\
\hline & 33 \\
\hline & 26 \\
\hline & 21 \\
\hline & 19 \\
\hline & 18 \\
\hline & 13 \\
\hline & 13 \\
\hline
\end{tabular}

Fonte: I Seminário do Habitat Ariano Constantino Dados de relatórios da Caixa Econômica
Federal e da Fundacáa Joáo
Pinheiro (2015). 
Os dados quantitativos, organizados na tabela anterior, também foram mapeados na escala do estado de São Paulo (figura 04). Pode-se ressaltar a concentraçấo da produçấo habitacional PNHR na Regiâo Oeste, caracterizada pela concentraçáo de assentamentos rurais e regiáo sul do Figura 04. Produção do PNHR estado pelo baixo PIB per capita.

no estado de São Paulo (até
2018).

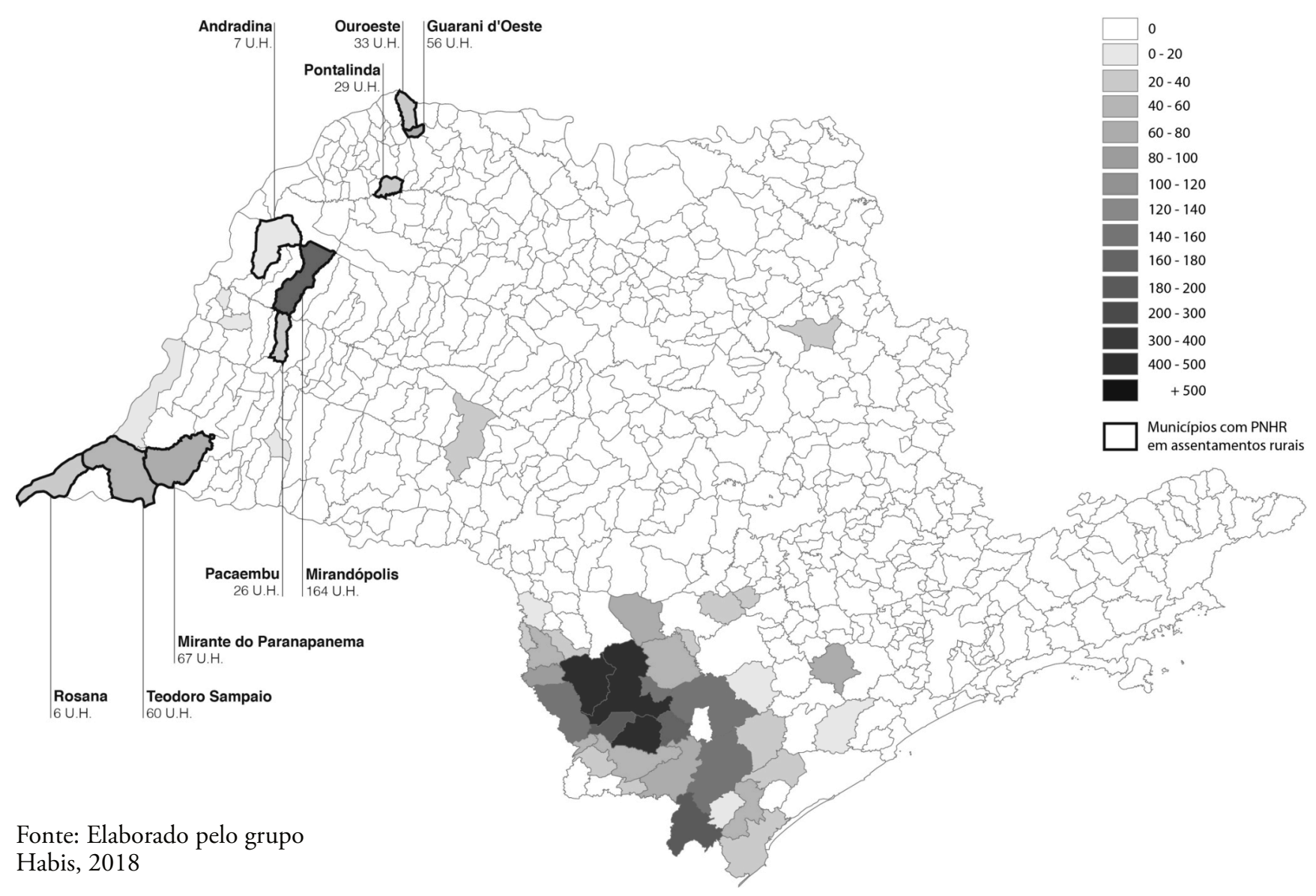

3.3. Arcabouço institucional do programa

Em primeiro lugar, é importante considerar que a produçăo habitacional para áreas rurais do PMCMV, que antes era responsabilidade do INCRA e do Ministério do Desenvolvimento Agrário (MDA), passou para o Ministério das Cidades. Segundo a Cartilha do PNHR do MCidades, o Banco Do Brasil S.A., por intermédio das Superintendências e a Caixa Econômica Federal (CEF), por meio das Gerências ou Representaçôes de Desenvolvimento Urbano e Rural - GIDUR ou REDUR, considerados os agentes financeiros, são os responsáveis por: fornecer a relaçẫo de documentos e formulários necessários à contratação das operaçōes de habitação rural; analisar os documentos das famílias beneficiárias e dos terrenos ou das propriedades rurais; aprovar toda a documentação entregue pela EO ou solicitar complementaçóes, caso necessário; firmar termo de cooperaçăo e parceria com as Entidades Organizadoras; firmar os contratos com as famílias beneficiárias; repassar os recursos por intermédio das Gerências Executivas de Habitaçáo (GHAB) de cada estado; autorizar a liberaçáo dos recursos mediante a apresentaçáo dos relatórios de execuçâo das obras e dos produtos do trabalho social combinados com vistorias técnicas; e atestar o fim das obras e do trabalho social e a entrega das unidades.

As Entidades Organizadoras - EOs, as quais podem ser públicas ou privadas, são organizaçôes sociais sem fins lucrativos. Segundo a mesma cartilha, estas entidades, após serem habilitadas pelo agente financeiro, deveriam ter a funçáo de levantar a demanda por moradias e reformas nas áreas rurais do país; solicitar e entregar a documentaçáo do 
beneficiários (RG, CPF, certidāo de casamento ou declaração de uniáo estável, documentos do cônjuge, comprovantes de renda, certidáo negativa de débitos com a Receita Federal); solicitar, complementar e entregar a documentaçáo sobre a propriedade, no caso dos posseiros de terras públicas e particulares com direito sucessório ou não; mobilizar as famílias beneficiárias na construção da proposta das habitaçōes rurais e das reformas, parte do trabalho social que deverá ser apresentado; propor e entregar os projetos técnicos e do trabalho social; convocar assembleia para eleição da Comissão de Representantes - CRE e entregar sua composição, de acordo com a orientaçáo do Agente Financeiro para analisar e contratar as operaçōes junto aos beneficiários; realizar o trabalho social e, em tese, fazer o acompanhamento das obras do PNHR, por meio dos respectivos responsáveis técnicos; apresentar ao Agente Financeiro os relatórios de engenharia e os produtos do trabalho social, durante a execução das operaçóes do PNHR, de acordo com as regras do Programa e o plano de trabalho aprovado; atestar o fim das obras e do trabalho social e a entrega das unidades aos beneficiários.

À Comissão de Representantes (CRE), eleita em assembleia e composta por no mínimo 3 (três) integrantes, sendo 2 (dois) eleitos dentre os beneficiários e 1 (um) representante indicado pela EO, cabe a responsabilidade pela gestáo dos recursos financeiros (assinatura das notas fiscais referentes a compras de materiais e pagamento da mão de obra, dentre outras funçóes), a prestaçáo de contas aos demais beneficiários, e a coordenaçáo da obra nas diferentes etapas, incluindo a organizaçăo de mestres de obras, pedreiros, serventes e profissionais especializados

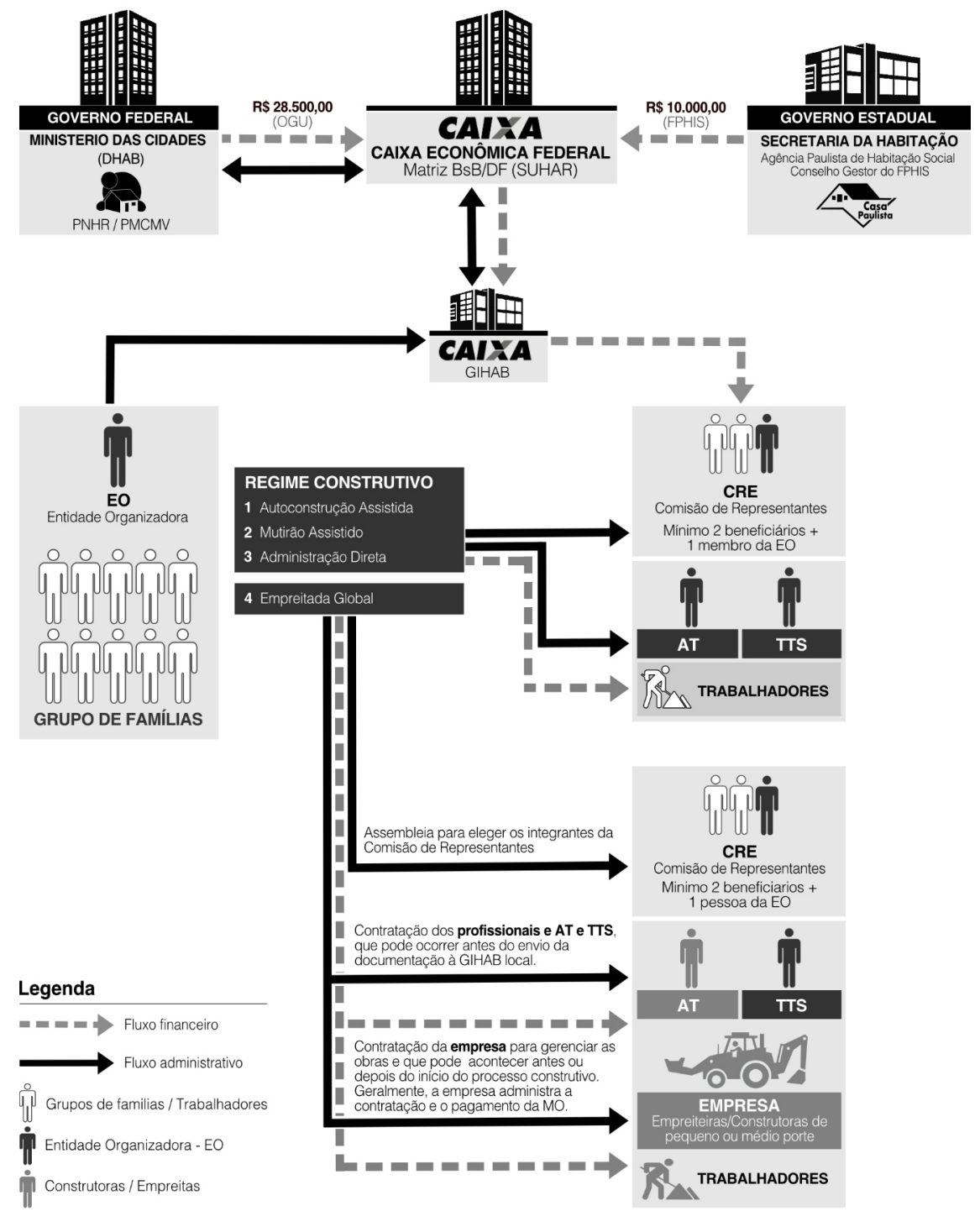

Já o Trabalho Técnico Social (TTS) deve contemplar estratégias de atuação de acordo com as diretrizes estabelecidas pelo programa. Ele é
Figura 05. Estrutura operacional

Fonte: Elaborado pelo grupo
Habis, 2018. 
dividido em três etapas: até 3 (três) meses na etapa pré-obras; até 12 (doze) meses na etapa obras; e até 3 (três) meses na etapa pós-ocupaçáo. A assistência técnica (AT) deverá ser prestada pela Entidade Organizadora por intermédio do responsável técnico das obras. Este profissional deve seguir as especificaçoes estabelecidas nos projetos de engenharia e arquitetura (especificaçōes mínimas definidas para as habitaçóes rurais). Podem atuar como responsáveis técnicos, dentro do limite de suas atribuiçôes, engenheiros civis, arquitetos, engenheiros agrônomos e agrícolas e técnicos em edificaçôes, devidamente registrados em seus órgãos de classe.

As questôes aqui esboçadas colocam para nós (arquitetos e acadêmicos) a necessidade de refletir a respeito das principais contradiçóes decorrentes da provisáo de moradia camponesa pelo Estado num contexto de produção e reprodução de capital. Assim, como veremos nos itens seguintes, através da pesquisa de campo, buscamos apreender como um programa como o PNHR, baseado na lógica de produçáo habitacional em escala, estruturado a partir de subsídios públicos e se submetendo na lógica do modelo capitalista, acaba conferindo à esfera privada a iniciativa e a responsabilidade não apenas pela qualidade dos empreendimentos, mas também pelo processo produtivo.

Contudo, diante deste cenário, os estudos sobre a habitaçáo ainda se limitam, principalmente, à dimensão do "consumo da habitaçâa", que enfatiza apenas o déficit na qualidade e no urbanismo. É necessário reconhecer que este tipo de produção "contribuiu para o conhecimento da situaçáo de precariedade habitacional existente e dos desvios nas políticas públicas, que se revelaram incapazes de sanar a carência das camadas mais pobres da populaçâo" (MARICATO, 2009, p. 34). Porém, segundo a autora, este enfoque teórico da esfera do consumo, que historicamente tem dominado a pesquisa acadêmica sobre habitaçáo social, raramente incorpora a produçâo da habitaçáo como parte fundamental na determinação do ambiente construído:

maior parte das pesquisas sobre habitaçáo se dão no contexto da esfera do consumo, dimensionando-o e qualificando-o. O Estado e as políticas públicas ocupam um papel central no conjunto desses trabalhos. Embora eles forneçam um quadro importante sobre a carência de moradias, segregaçáo territorial, a exclusáo social e as políticas institucionais
ignoram, frequentemente, a centralidade da produçáo na determinaçáo do ambiente constrúdo (MARICAT)

Estas análises orientadas para o consumo e circulação, segundo Ball (1986, p. 160), têm a tendência a considerar a luta de classes, as relaçốes e os conflitos sociais como questôes externas à esfera habitacional, não reconhecendo este aspecto como fundamental dentro da estrutura de provisão, o que pode levar a análises incorretas sobre as particularidades e seus problemas e, consequentemente, negar a necessidade de uma reforma na provisão de habitação. Em contraste com este foco, faz-se necessário que os estudos sobre habitação abordem o processo físico de produçáo, além de incorporar as relaçōes sociais estabelecidas neste processo. Segundo (BALL, 1986), diferentes combinaçôes entre conjuntos particulares de agentes envolvidos na produçáo e consumo de habitação, sejam estes sociais ou institucionais, estruturam a natureza, as características e os efeitos do arcabouço na provisáo de habitação.

Finalmente, faz-se fundamental colocar a questão da habitação social 
nas áreas rurais em outro patamar de reflexão, integrando as análises referidas à produção dos ambientes construídos, ou seja, à compreensão do projeto simultaneamente à questão fundiária, ao financiamento, à articulação de agentes, aos processos tecnológicos e de produção, e ao trabalho em canteiro de obras.

\section{Construção da pesquisa}

Ao longo destes quatro anos, este projeto de pesquisa passou por um contínuo processo de reformulação. Seus objetivos e principais questôes foram constantemente revisadas a partir das viagens de campo, da sistematização dos dados e das discussōes teóricas ao interior da equipe de trabalho da pesquisa: "Produçáo do PNHR/PMCMV nos assentamentos de reforma agrária do estado de SP: inserçáo territorial e avaliaçáo arquitetônica, construtiva e tecnológica" ${ }^{\prime 1}$. Esta pesquisa desenvolvida no período de novembro de 2014 a junho de 2018 me permitiu compreender náo apenas os conflitos e contradiçóes próprios dos processos de territorialização e construção do habitat destas comunidades - de fundamental importância -, mas também se tornou num exercício de questionar meus próprios posicionamentos a respeito do lugar do arquiteto na formulaçáo de soluçôes a estes problemas.

Após as primeiras viagens exploratórias da pesquisa coletiva, eu me propunha a estudar o projeto arquitetônico, área que precisa ser qualificada a fim de responder mais especificamente às necessidades individuais dos grupos familiares estudados. Apoiado no acúmulo e na minha experiência como arquiteto e designer em projetos de habitaçáo de interesse social, pretendia estabelecer recomendaçốes de projeto para produçăo habitacional voltada para os estratos populacionais de renda baixa no âmbito do Programa Nacional de Habitação Rural (PNHR). Esta pesquisa de caráter exploratório e qualitativo apresentava para mim, nesse momento, o rumo teórico e metodológico que, de alguma forma, revelaria as principais contradiçóes inerentes à qualidade do ambiente construído nessas áreas.

No processo de coleta de dados, produto das quatro viagens de campo, concernentes aos contratos habitacionais, ainda me mantive refletindo sobre a qualidade do projeto arquitetônico. No entanto, várias questôes suscitadas nos canteiros dos assentamentos me despertaram interesse. Em termos gerais, estas situaçóes com as quais me deparei no transcurso da pesquisa demonstraram que a questáo habitacional nas áreas rurais, especialmente nos assentamentos de reforma agrária, está sendo "construída" a partir do nosso próprio desconhecimento teórico e prático em termos de arquitetura e planejamento. As três questôes que serão apresentadas não são indicadas aqui enquanto dimensôes analíticas propriamente ditas, mas sim permitem organizar e confrontar as particularidades encontradas na produçáo habitacional destes assentamentos de reforma agrária estudados, problematizando seu processo de concepção e construção.

A primeira questão que chamou minha atençăo foi a relacionada com o funcionamento, a articulaçáo e as dinâmicas da estrutura de provisão habitacional. Não apenas ao arcabouço institucional que, por causa da burocratizaçáo, acaba interrompendo o cumprimento dos cronogramas 
de obras, ocasionando atrasos e perda de materiais. Também, e ainda mais interessante, o referente aos agentes que atuam diretamente na produçấo habitacional: trabalhadores, com condiçôes de trabalho e financeiras muito precárias; famílias, sem participaçáo no processo e autonomia; assistentes técnicos, comumente mal remunerados e pouco valorizados; e Entidades Organizadoras transferindo as principais responsabilidades a empresas construtoras com a possibilidade de assumir financeiramente estes empreendimentos.

A segunda questáo se relaciona com a tecnologia e as características do canteiro. Uma das situaçóes encontradas nas viagens de campo se associa com o tipo de canteiro, que geralmente se configura como disperso, situação que somada à falta de água e energia, às más condiçóes das estradas no interior dos assentamentos e à ausência de recursos do programa para esta situaçáo particular (falta de recursos suficientes para compra ou aluguel de ferramentas e máquinas, compra de combustível para geradores, ou até pagamento de assessoria técnica adequada), prejudica seriamente a logística nestes canteiros de obras, como atrasos nos cronogramas, aumento de custos e conflitos entre famílias e técnicos encarregados. De outro lado, a incompatibilidade com as diferentes realidades do campo, como cultura, períodos de safra, dinâmicas de trabalho dentre outras, com os cronogramas propostos (impostos) pelo programa. E, finalmente, a união de diversas tecnologias construtivas de características diferentes, encontrando num mesmo canteiro tecnologias baseadas na manufatura como a alvenaria, que ainda depende da habilidade do trabalhador e da racionalizaçáo de processos no canteiro de obras como, por exemplo, o uso de argamassa de revestimento pronta e o uso de concreto usinado.
A terceira das questôes se relaciona com o projeto de arquitetura, ou seja, o evidente uso de modelos organizacionais conservadores e altamente padronizados e, por conseguinte, a inadequaçáo ao tamanho das famílias e modos de vida. Esta padronizaçáo arquitetônica se associa diretamente com a padronização do processo de produçáo (SHIMBO, 2010, p. 205). Ou seja, projetos arquitetônicos e a definiçáo dos ambientes internos regulados, pelo melhor aproveitamento dos materiais e componentes comercializados e pelos processos de execução e gestáo no canteiro.

Estas três questôes - ou o conjunto delas - observadas na pesquisa de campo, juntamente às discussôes teóricas, extrapolam o simples debate do projeto arquitetônico para habitação social rural. Colocando e exigindo para mim novas abordagens que me permitissem compreender os elementos constitutivos destes fenômenos, seus arranjos e dinâmicas internas e os princípios que regulam seu surgimento e expansão, enfim, a partir da adequada interpretaçáo das evidências da pesquisa empírica, para que seja possível fazer uma aproximaçâo crítica e rigorosa dessas realidades concretas.

Uma das principais características observadas no setor da produçáo habitacional é que este é um sistema de caráter heterogêneo, isto quer dizer que coexistem, combinam-se e articulam diversas modalidades de produçăa $0^{20}$. Não nos referimos apenas à simultaneidade de formas de produção e consumo mercantilizadas e socialmente desvalorizadas como colocado por Pírez (2000, p. 96). Também, diretamente no canteiro, há uma combinaçáo de elementos "novos" com elementos mais "simples", uma continuidade da produçáo manufatureira, com
20. A coexistência de várias formas de produção Escola do Fe conhecida como a Escola das Formas de Produçáa Pradilla, 1976; Pradilla, 1987; chteingart, 1989;). Esses entre algumas categoriass ,como 0 Modo de Produçăo, Formação Social e Forma de Produçáa 
pouca mecanizaçáo e emprego abundante de mão de obra, coexistindo com elementos mais sofisticados, que envolvem saberes especializados com um certo grau de padronização da produçấo (SHIMBO, 2016, p. 127)

Esta multiplicidade de formas de produçáo se concebe como o resultado do processo de introduçấo das relaçốes capitalistas no setor da produção habitacional. Porém, este setor da construçáo apresenta uma série de circunstâncias específicas - obstáculos - que fazem particularmente difícil a introduçáo e o posterior estabelecimento do capital (JARAMILLO, 1982, 1986; PRADILLA, 1983). Dentre os principais obstáculos que a produçáo habitacional coloca, podemos mencionar: o longo período de rotaçấo do capital, principalmente pelos extensos períodos de trabalho necessários para finalizar um "produto"; a relação da produção e a base fundiária, o terreno se constitui um objeto de valorizaçáo, desta forma, funciona como objeto de disputa de rendas (MARICATO, 2009, p. 41); e a vulnerabilidade da produção diante das constantes flutuaçôes da economia. Assim, do mesmo modo que existem obstáculos, o capital busca mitigar estes impedimentos por meio de distintas estratégias conforme as características de cada formaçăo social. Tais fenômenos - obstáculos e estratégias - são expressados aqui de forma geral. Contudo, especificamente para nosso caso da produção habitacional em assentamentos de reforma agrária, surge a questão: quais são as condiçōes específicas que dificultam - e por que nấo - facilitam a consolidação destas formas de produção nas áreas rurais?

Torna-se necessário discutir estes componentes, suas interaçóes dinâmicas com base na observaçáo das particularidades nestes contextos. Esta aproximaçáo nos permite compreender sua manifestaçấo concreta. Segundo Samuel Jaramillo (1982, p. 210), as formas de produção do espaço construído raras vezes se apresentam em estado puro, encontrando: as formas modificadas, que apresentam alteraçóes em algum componente; as formas transitórias; e as formas mistas, diferentes formas em um mesmo processo produtivo. Nos países periféricos e dependentes, estas variáveis, e outras possíveis, se apresentam de forma mais pronunciada e com maior incidência social.

\subsection{Hipóteses e objetivo da tese}

De forma geral, partimos do suposto teórico de que a moradia - sua produçăo, circulação e consumo -, como objeto de estudo, pode ser isolada em termos metodológicos. Porém, a moradia como estrutura complexa, só encontra explicaçáo a partir da interpretação dos fenômenos que acontecem no seu próprio contexto.

A hipótese principal desta proposta de pesquisa é de que, atualmente, estấo se consolidando novos arranjos de produçáo habitacional nos assentamentos de reforma agrária, produto da introduçáa, da coexistência e da articulaçấo das diversas formas de produçấo nestas formaçốes sociais particulares. As modalidades que este processo de introdução das relaçôes capitalistas adquirem em um determinado lugar são moldadas pelas características sociais, culturais e políticas de cada formaçáo social, pelas particularidades do contexto, e até mesmo pela história específica de cada lugar. Por conseguinte, têm um impacto decisivo náo apenas no resultado físico do espaço construído, nos padróes tecnológicos e nas relaçóes entre grupos sociais, como também contribui, segundo Jaramillo (1982), para aumentar o processo de 
21. Parte desta fase de coleta untamente à equipe do projeto de PMCMuisa. Yroduçáa do PNHE reforma agrária do estado de $S$ inserçâoo territorial e avaliaçẩo arquitetônica, construtiva cnológica" num período proximadamente três anos. acumulaçáo de capital, que em si tem uma magnitude considerável e de crescente importância.

A partir das questôes apresentadas até aqui e diante da necessidade de construir um escopo teórico próprio às particularidades do campo brasileiro, o propósito desta tese é:

Descrever e analisar como se dá a consolidação dos processos de produção habitacional camponesa em três assentamentos de reforma agrária da Regiáo Oeste do estado de São Paulo no âmbito do Programa Nacional de Habitaçáo Rural (PNHR), vinculado ao Programa Minha Casa, Minha Vida (PMCMV). Para tanto, a pesquisa é estruturada em três abordagens principais, que comumente são tratadas como temas separados, porém, aqui, serão estudados paralelamente: i) o arranjo produtivo, a categorizaçáo dos diferentes agentes que atuam nos processos construtivos e de gestáo das casas, procurando compreender suas características, funçóes e dinâmicas na realidade estudada; ii) tecnologia e processos de produçáo em canteiro, mostrando a interação dos diferentes tipos de tecnologias com as condiçōes próprias do lugar, fato que acaba alterando o espaço construído, a natureza organizacional e a posiçấo do trabalhador neste processo; e iii) o projeto, sua relaçáo com o processo produtivo, o concebido ante o executado e o lugar do arquiteto na formulação de soluçōes para estes territórios.

\subsection{Sobre o Método}

Visando compreender as questóes colocadas anteriormente e atender aos objetivos propostos, precisei, paralelamente à pesquisa de campo ${ }^{21}$ - definida aqui como a estratégia central deste projeto - abordar algumas dinâmicas metodológicas que me permitissem apreender integralmente esses questionamentos. Desta forma, tornou-se fundamental realizar: i) a pesquisa documental de fontes primárias e secundárias; ii) diversas entrevistas com as famílias assentadas e com agentes sociais, empresariais e institucionais envolvidos nos processos de projeto e produção dos contratos habitacionais selecionados; iii) a própria pesquisa de campo nos assentamentos escolhidos; e iv) o levantamento e revisão de literatura.

Com relação à pesquisa documental, foram coletadas, até o momento, inúmeras informaçōes de caráter quantitativo e qualitativo, como dados referentes à produçăo habitacional do programa, às cartilhas e às normativas. Alguns desses documentos foram obtidos a partir de consultas nos próprios sites das instituiçóes ou solicitados via e-mail e telefone. Algumas destas instituiçôes são: a $\mathrm{CDHU}$; a Companhia Regional de Habitaçóes de Interesse Social (CRHIS); a Secretaria de Habitação do Estado de SP; o Ministério das Cidades; o INCRA; a CEF/Brasília e; o ITESP. Além disso, algumas Cooperativas, Associaçóes, Movimentos e Sindicatos como: o MST; a COOPMAPAAI; a FETAESP; a COOPAF e, por fim, as empresas e os escritórios que gerenciaram os contratos do PNHR nos assentamentos, que denominarei (Empresas A, B, C, D, E) e; as respectivas Entidades Organizadoras (EOs)

Foram realizadas diversas entrevistas abertas e semiestruturadas no três assentamentos rurais, ao todo foram realizadas entrevistas a 14 representantes dos Movimentos, Sindicatos e Entidades Organizadoras; a 8 representantes das empresas construtoras envolvidas no processo de produção; e, principalmente, a 55 moradores e 8 trabalhadores presentes nos empreendimentos estudados. 
Para a pesquisa de campo, foram selecionados três assentamentos rurais localizados na Região Oeste do estado de São Paulo, especificamente nas regiōes administrativas de Araçatuba e Presidente Prudente, regióes administrativas com a maior quantidade de assentamentos rurais implantados e de famílias assentadas no estado. Sendo $7,86 \%$ na região de Araçatuba e $66,58 \%$ no Presidente Prudente, somando ao todo 129.381 (de 199.843 no estado) famílias assentadas até 2012. Esses dados confirmam a maior concentração dos conflitos fundiários do estado e, consequentemente, a enorme demanda habitacional na faixa de agricultores familiares beneficiários pelo Programa Nacional de Reforma Agrária (PNRA). Desta forma, pode-se destacar a importância desta área para o presente estudo.

Estes assentamentos estáo divididos em cinco contratos, os primeiros do estado a acessarem os recursos do PNHR, somando 227 famílias (unidades construídas) (figura 06): i) Florestan Fernandes (Mirandópolis), assentamento criado em 2013 pelo Programa Nacional de Reforma Agrária (PNRA) com uma extensão de 2.868 ha, está dividido em dois contratos do PNHR, sendo o primeiro com 120 unidades habitacionais e o outro com 44 casas; ii) Boa Esperança (Pacaembu), criado em 2008 pelo Programa Nacional de Crédito Fundiário (PNCF), tem uma extensáo de 232 ha e um contrato de 26 casas e; iii) Dona Carmem (Mirante do Paranapanema), criado pelo PNRA, tem uma extensão de 1.216 ha e dois contratos do PNHR, um composto por 10 casas e o outro por 27 casas. Desta forma, como parte da pesquisa coletiva foram realizadas quatro viagens de campo, estas viagens abordam diversos objetivos que são descritos a seguir.

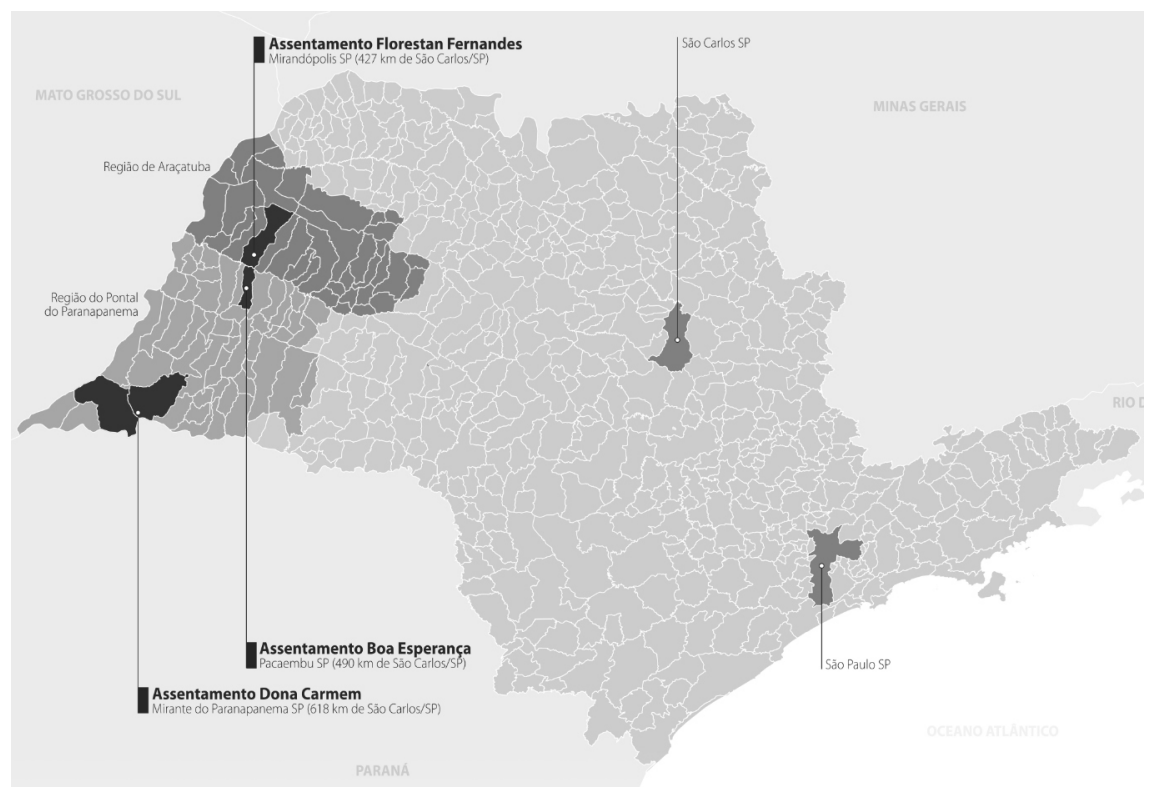

A primeira viagem de campo (12 a 13 de fevereiro de 2015), de caráter exploratório, tinha como propósito fazer uma visita de reconhecimento ao assentamento rural Florestan Fernandes, localizado no município de Mirandópolis, e que, segundo informaçóes obtidas inicialmente na internet, este era o primeiro assentamento de reforma agrária no estado de São Paulo a acessar os recursos do PNHR. Desta forma, procuramos responder questôes gerais, que incluíam o histórico do assentamento, suas características físicas, organizaçáo social e política e, de outro lado, as características técnicas e arquitetônicas dos contratos. Esta coleta preliminar de dados se baseou na realizaçáo de entrevistas abertas com representantes técnicos dos dois contratos desenvolvidos no assentamento e visitas aos lotes de alguns assentado 
beneficiários do programa, que permitiu, além de registros fotográficos, a observação direta do processo de construçấo, que nesse momento estava nas etapas de fundaçóes e levantamento de alvenaria.

Após a primeira visita de campo, foram solicitadas informaçôes à Caixa Econômica Federal referentes aos contratos do PNHR aprovados em todo o Brasil. Desta forma, foi possível verificar que, no estado de São Paulo, dois assentamentos rurais adicionais estavam com contratos aprovados e em construçâa. Estas informaçóes permitiram planejar a segunda viagem de campo (14 a 16 de julho de 2015), com o objetivo de retomar os contratos do assentamento Florestan Fernandes, incluindo também os assentamentos Boa Esperança, localizado no município de Pacaembu, e o assentamento Dona Carmem, localizado na divisa dos municípios Mirante do Paranapanema e Teodoro Sampaio, na regiáo do Pontal do Paranapanema. Esta viagem também incluiu uma reuniáo com representantes do escritório responsável por um dos contratos que, na época, estava em andamento no assentamento Dona Carmem.

Visando consolidar as informaçōes referentes aos cinco contratos, foram elaborados roteiros específicos para a terceira viagem de campo (03 a 09 de dezembro de 2015), estruturados em cinco grupos de agentes: a) Famílias beneficiárias pelo PNHR, nos diferentes estágios das obras; b) Trabalhadores contratados (pedreiros, serventes ou mão de obra especializada) presentes nos canteiros de obra; c) representantes das EOs dos contratos em andamento; d) representantes das empresas construtoras ou escritórios responsáveis pelos e projetos e gerenciamento das obras; e e) responsáveis pelas Assessorias Técnicas (AT) e o Trabalho Técnico Social (TTS). Também foram elaborados registros e anotaçóes a partir da observacăa direta dos lotes dos assentados, verificando as medidas das unidades habitacionais, de modo que fosse possível, após o retorno, transferir as dimensōes reais dos projetos para softwares específicos, para assim gerar os detalhamentos desejados.

Após a sistematização dos dados levantados na viagem anterior, foram elaborados para a quarta viagem de campo (31 de maio a 06 de junho de 2016), roteiros mais detalhados com o objetivo de complementar as informaçóes empíricas coletadas até aquele momento e retornarmos a alguns lotes que já haviam sido visitados e conversarmos com outras famílias assentadas de interesse para a pesquisa. Esta viagem também incluiu visitas e reunióes com outros agentes institucionais e sociais envolvidos com os contratos de produção habitacional: a) com o presidente da Cooperativa de Pescadores e Produtores da Agricultura Familiar (COOPPAF), responsável pelo segundo projeto habitacional do PNHR desenvolvido no assentamento Dona Carmem; b) com representantes da EO responsáveis por um dos contratos desenvolvidos no assentamento Florestan Fernandes; e c) com a engenheira responsável pela assessoria técnica deste mesmo contrato e com o presidente do Sindicato dos Trabalhadores da Agricultura Familiar (SINTRAF).

Com a finalidade de estruturar um recorte teórico, é realizada uma investigaçāo exploratória, conduzida por meio de levantamento de revisáo bibliográfica, coletado principalmente em livros, artigos científicos, teses, manuais e normas técnicas. O levantamento voltou-se às seguintes temáticas: a) habitaçáo no meio rural, ampliando a compreensáo sobre o tema, principalmente em aspectos como as 
condiçôes atuais da habitaçâo no campo e políticas de habitação social; b) as contradições presentes na inserção de "novas" tecnologias no processo de produçăo habitacional no Brasil e América Latina; c) sobre o trabalho, procurando entender os processos de trabalho em canteiros de obras, treinamento da força de trabalho e controle da produtividade; e d) outras abordagens a respeito do projeto arquitetônico de habitaçáo de interesse social.

\subsection{Tratamento dos dados e ferramentas analiticas}

A fim de definir ferramentas que auxiliem o processo de organizaçáo e sistematizaçấo dos dados e o próprio processo analítico das questôes colocadas, parti de algumas noçôes teóricas que se adequaram ao teor das informaçóes coletadas. Dada a natureza heterogênea destas questôes, esta pesquisa combina a abordagem empírica do problema com um sistema de categorias mais rigoroso, que permite o tratamento sistemático destas informaçōes. Na tentativa de conseguir uma maior aproximação à realidade estudada, foram necessárias algumas variaçóes para este caso particular, acrescentando ou adaptando alguns elementos que consideramos fundamentais para o entendimento do problema.

Samuel Jaramillo $(1982,1986)$, em sua discussáo sobre as formas de produção-circulação do espaço construído, apresenta várias conceituaçóes bastante pertinentes a serem incorporadas ao debate relacionado aos processos tecnológicos e de produçáo de moradia, refletindo, assim, sobre boa parte das contradiçóes resultantes do fenômeno estudado. $\mathrm{O}$ autor parte de uma categorizaçáo que determina náo apenas o lugar que ocupam os principais atores envolvidos na produção habitacional, como também suas funçōes e dinâmicas. Estas categorias são: i) trabalho direto; ii) controle técnico da produçáo; iii) controle econômico direto da produçáo; e iv) controle econômico indireto da produçáo.

Além disso, a partir da compreensão do conceito de tecnologia desenvolvido por Ruy Gama (1986) no texto "Tecnologia e Trabalho", é possível, além de organizar as informaçóes, compreender o processo construtivo das unidades habitacionais. $\mathrm{O}$ autor define quatro componentes que juntos definem o conceito de tecnologia: i) o trabalho, entendido como a açẫo do homem dirigida à transformação da natureza e, consequentemente, a ele mesmo, ação sempre orientada por um projeto; ii) os materiais, que se relacionam ao estudo dos materiais passíveis de transformaçáo, que váo desde as matérias primas, que estâo no início de uma cadeia, até os materiais ou componentes usados na fabricaçáo dos mais variados objetos de uso diário, domésticos ou industriais; iii) os meios de trabalho, os quais são um conjunto de coisas que o trabalhador coloca entre si mesmo e o material como o conhecimento dos instrumentos, ferramentas e máquinas, e o da utilizaçáo da energia incorporada para a transformaçáo da natureza; e iv) a praxiologia, que reúne um conjunto de disciplinas e técnicas que alimentam e dáo apoio aos outros componentes da tecnologia. Por exemplo, no caso de um canteiro, como é orientada a economia dos atos; a instrumentação e utilização dos meios materiais e a organização e interaçáo dos diversos agentes.

\subsection{Organizaçáo da tese}

A partir da necessidade de um olhar mais abrangente, entendendo a moradia como uma estrutura complexa, é estruturada a presente tese, organizada em cinco partes: a introdução, três capítulos e as consideraçōes finais, partes que são divididas por subitens numerados 
sequencialmente, de modo a facilitar sua leitura e a compreensáo do seu conteúdo.

Antes de abordar o objeto empírico e o processo de análise dos dados coletados, a Introduçáo desta tese pretende abrir a discussão das dinâmicas e dos conflitos no processo de produçáo da moradia camponesa promovida pelo Estado no meio rural. Desta forma, os itens subsequentes desta parte inicial trazem: i) a caracterização do campesinato brasileiro na atualidade, apresentando o cenário atual e a necessidade de colocar a questáo habitaçáo social no campo em outro patamar de discussão; ii) as articulaçōes e contradiçōes da propriedade da terra no processo de produçáo de moradia; iii) o debate acadêmico e contexto histórico da produção de moradia rural, focalizando nos programas voltados à produçáo de habitaçáo social, buscando aprofundar sobre seu escopo e procurando qualificar a produçáo recente do PNHR no estado de São Paulo e o arcabouço institucional do programa; e iv) o processo de construçáo da presente pesquisa de doutorado, trazendo as principais questôes que surgiram ao longo do projeto e, decorrente destas questôes, a construçáo da hipótese e o propósito da presente tese.

No Capítulo I, é abordado, em primeiro lugar, a descriçăo dos contratos a partir das informaçóes coletadas nos estudos de caso escolhidos. E feito um retrato do processo construtivo, que permitiu compreender, no tempo, o funcionamento do processo de produção e as mudanças nos planejamentos resultantes dos diferentes fenômenos ocorridos na etapa de construção. Neste processo descritivo, foi possível também: i) abordar a questão relacionada com a posiçăo que ocupam as Entidades Organizadoras (EOs) e a entrada das empresas construtoras no cenário de produçáo habitacional no campo; e ii) discutir a respeito das modalidades de subcontratação encontradas nos contratos estudados (a subempreitada e a terceirizaçăo) compreendendo as características destas modalidades, assim como as alteraçóes no canteiro de obras.

Em termos gerais, no Capítulo II é discutido sobre o tema referido à tecnologia e ao canteiro. Assim, com intuito de compreender a realidade destes empreendimentos, são abordadas as seguintes questôes: i) em primeiro lugar, são descritas as particularidades físicas do canteiro de obras que, no caso particular deste estudo, configuram-se como pequenos canteiros dispersos, além de descrever as condiçóes de infraestrutura nos assentamentos (redes de água e energia), situaçóes que definem a forma como são produzidas estas moradias; e ii) a discussão referida às práticas construtivas presentes nos canteiros, descrevendo as ligadas à manufatura e as mudanças introduzidas por processos, materiais, componentes e sistemas construtivos racionalizados, principalmente, relacionado à submissáo da forca de trabalho.

Finalmente, no Capítulo III é feito o debate sobre o entendimento da arquitetura, não apenas baseado no seu potencial para qualificar o espaço construído, mas também como produto material das relaçóes sociais concretas e sua capacidade de produzir ainda novas relaçôes de produçấo. Desta forma são: i) descritos os projetos habitacionais a partir da dicotomia entre o projeto e o canteiro, ou seja, é feita uma análise das deficiências surgidas das padronizaçăo do projeto concebido 
e as diferentes alteraçôes (da empresa ou por iniciativa das famílias) que surgiram por causa da inexistente participação das famílias no processo de concepçáo; ii) discutidas as contradiçôes da introduçấo do projeto, fruto do processo produtivo parcelar dos arquitetos, engenheiros e

técnicos no canteiro, situaçáo que acaba por atribuir uma posiçáo de autoridade destes profissionais e do próprio projeto sobre o trabalho alheio; e iii) repensar a inserçấo social e política do profissional no projeto concebido e executado nas comunidades e sua real posiçâa no arcabouço do processo de produçáo do espaço. 


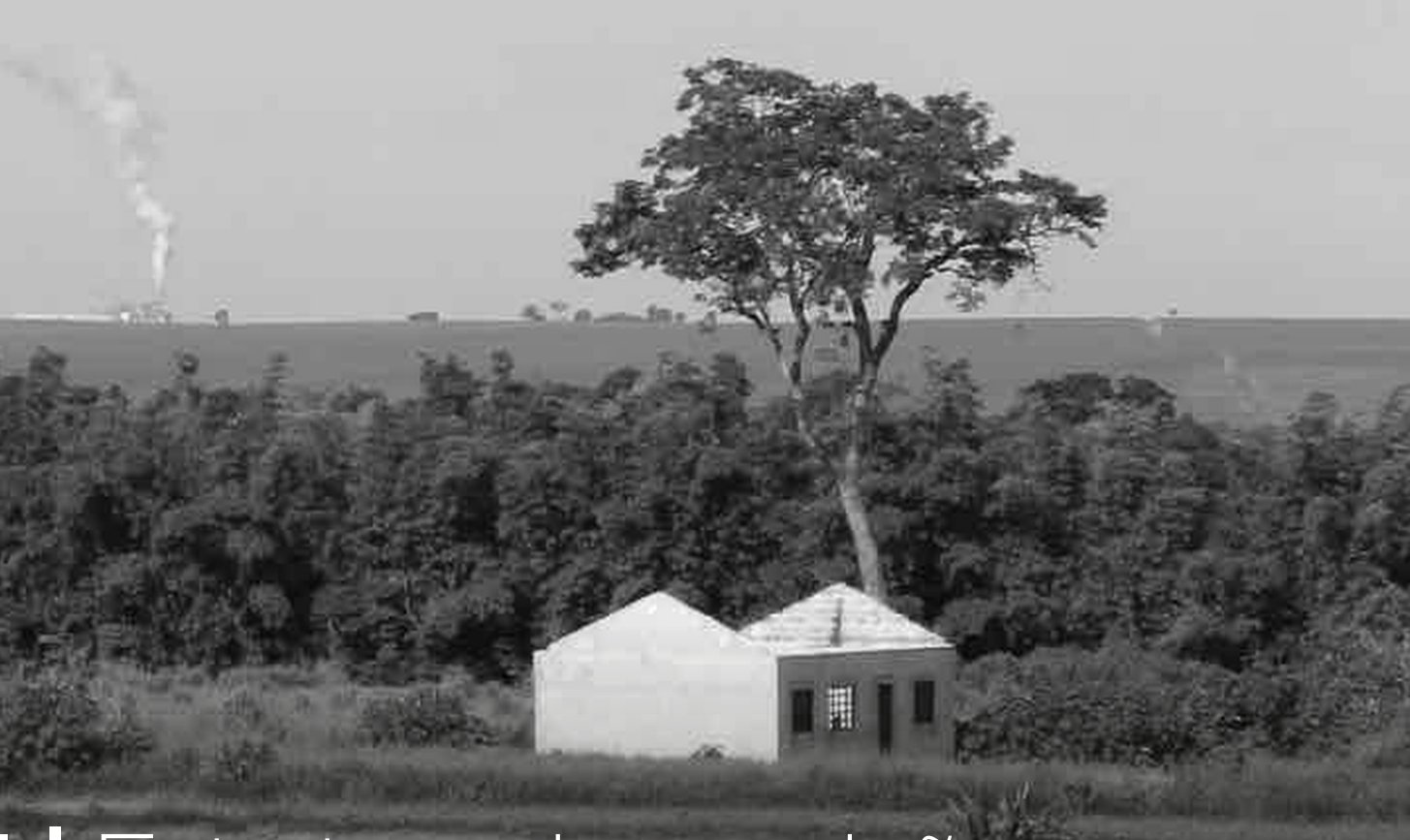

-Apítulo I I Estrutura de provisão habitacional do PNHR

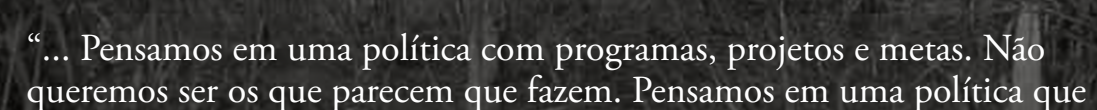
queremos ser os que parecem que fazem.
provocasa e cumpre sua razáo essencial: muda consciéncias, estimula participacáá, abre espaço; faz da democracia nâo um jogo de aparêncialas 
5. Funcionamento e gestão da produção

\section{habitacional: projeto e obra}

5.1. Regimes produtivos nos programas de moradia rural

Em termos gerais, as características dos programas de provisão habitacional para o campo têm apresentado algumas transformaçôes e adaptaçôes nấo apenas na concessão, como também na aplicaçắo dos recursos, de fundamental importância como colocado anteriormente. Porém, uso aqui a descrição dos regimes construtivos mais comuns destes programas habitacionais como argumento para justificar o pouco avanço na própria forma de construir, além da inadequação do modelos de produçáo implantados pelo atual programa, tornando-se necessário estudar estas questôes de maneira mais aprofundada, na tentativa de compreender estes regimes na prática, mais especificamente nos casos estudados.

Nos programas habitacionais apresentados no item 3 , os modelos de regime construtivo que predominaram - e ainda predominam, em teoria - são o mutirão e a autoconstruçáa ${ }^{22}$, encontrando algumas particularidades que tentarei descrever ao longo do texto. Em primeiro lugar, estes modelos de construção por autoajuda e ajuda mútua se diferenciam completamente dos desenvolvidos nas periferias das grandes cidades. No campo, estas práticas de construçáo são muito comuns, pois, contextualizadas às características dessa formaçấo social, tornam-se as mais adequadas às condiçóes do lugar. Não obstante, desenvolvidas a partir da lógica de um programa habitacional, que depende de rigorosos controles do processo e da liberaçáo de recursos, as dificuldades e contradiçôes se tornam inevitáveis.

22. É comum confundir estas
duas modalidades. As duas têm em comum o fato de que, tanto no sistema de mutitáo quanto
no de autoconstrucăo assistida necessário o o superviçáa assisistida do canteiro de obras. No entanto, a principal diferenç

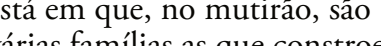
um conjunto de moradias e, na autoconstrução, éa própriia família quem constrói a sua 
24. Esta organizaçáo se consolida Parceria, firmado entre a CEF e associaçáo de beneficiários, em que se define o grau de participaçâa dos envolvidos, a obrigatoriedad de AT e no qual se permite arquitetônicoss, sem padronizaçós
(SILVA, 2014, p. 87).

25. O projeto INOVARURAI "Habitaçăo rural com inovaçōes no processo, gestáo e produto: sistemas construtivos com recursos locais e renovaveis', fo desenvolvido de 2004 a 2006 no em Itapeva, SP, e contou com ursos do Programa de Subsídi à Habitaçáo de Interesse Socia (PSH-Rural) e do INCRA para habitacionais, com a coordenaçāo e acompanhamento do grupo de pesquisa em Habitaçäo e
Sustentabilidade (HABIS).
O programa denominado CC-FGTS no modelo de Operaçóes

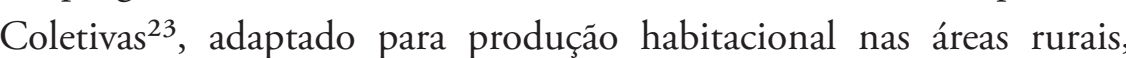
definia a contrataçáo na modalidade de aquisiçấo de material de construção para unidades novas, reforma ou ampliaçăa. Este programa estabelecia diversos regimes de construçấo (administraçáo direta, autoconstruçáo assistida, empreitada global, ou mutirăo assistido) sem fazer exigência na escolha, recomendava a organizaçáo coletiva dos beneficiários, bem como treinamento para o trabalho em mutirão. Porém, o financiamento (a quantidade e o destino do recurso) não se adequava à diversidade de regimes propostos pelo programa.

O PSH-rural dá continuidade à possibilidade de implementar o regime de mutirão para a construçấo das casas. No entanto, o programa traria como novidades: a organização dos beneficiários por uma entidade privada sem fins lucrativos ${ }^{24}$, a possibilidade da utilizaçáo de materiais não convencionais, o incentivo às atividades de geraçáo de trabalho $e$ renda e a discussáo do projeto junto com as famílias. A título de exemplo, estas novidades foram vistas pelas famílias e pelos pesquisadores do projeto habitacional desenvolvido no assentamento rural Pirituba ${ }^{25}$ como uma das principais vantagens do programa, sendo consideradas como um avanço em relaçáo a outros programas. Estas novidades foram bem aceitas se comparadas com o programa estadual Pró-Lar Rural que, apesar de definir, na produçáo de nova unidade, o regime de autoconstruçáo assistida no próprio lote, caracteriza-se por implementar e exigir uma planta padráo de $43,18 \mathrm{~m}^{2}$ (figura 07) e uma lista de materiais específicos, cuja compra e administração da própria obra fica sob a responsabilidade da prefeitura. De fato, a CDHU utiliza a padronizaçáo do projeto e sistema construtivo como meio de agilizar o processo e liberaçáo dos recursos, pois a elaboraçấo de um projeto para cada contrato, segundo a Companhia Estadual, poderia tornar-se demorada, trabalhosa e, nas mãos do município, atrasar estes empreendimentos (ALMEIDA, 2008, p. 56).
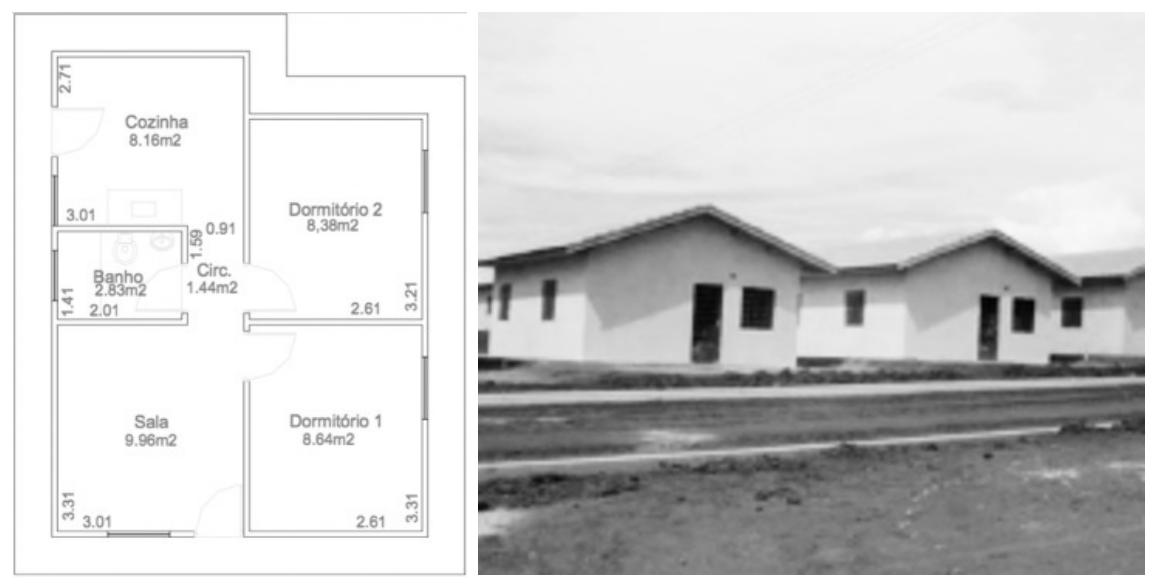

As três linhas de financiamento que compóem o PNHR, na sua primeira versáo até 2009, já estavam adaptadas à realidade rural e movimentos sociais e cooperativas rurais vinham operando a partir do regime de construçấo por mutirāo ou pela autoconstrução com supervisionamento do canteiro de obras. Vale a pena destacar que o Crédito Solidário - FDS é o primeiro programa projetado exclusivamente à autogestão habitacional, por meio de cooperativas e associaçóes como Entidades Organizadoras (EO). Apesar de todas as dificuldades enfrentadas pelo Crédito Solidário (modalidade do PNHR 2003-2009), é importante ressaltar seu pioneirismo ao propor as contrataçóes direta e exclusivamente com entidades habitacionais
Figura 07. Projeto Padrão do
Pró-Lar Rural - CDHU. Fonte: (ALMEIDA, 2008)
Dados (CDHU, 2006) 
privadas, sem fins lucrativos. Essa iniciativa deu origem ao Programa Habitacional Popular Entidades (PHPE), no âmbito do Programa Minha Casa, Minha Vida (SILVA, 2014, p. 91).

Outro avanço importante do novo modelo da Carta de Crédito CCFGTS (como parte do PNHR) foi trazido pela resoluçáo 460/04 do Conselho Curador do FGTS. Segundo Silva (2014, p. 136), esta modalidade considerou a diversidade dos custos de produçáo e aquisição de imóveis de acordo com o porte e a localização dos municípios - que traduzia-se em diferentes valores de subsídios por tipo de município, e definiu que, quanto menor fosse a renda da família beneficiária, maior seria seu subsídio contratado.

Já o PNHR, como integrante do Programa MCMV, não apresenta grandes novidades. Da mesma forma que a modalidade urbana Entidades do PMCMV, os beneficiários devem ser organizados de forma coletiva em torno de uma Entidade Organizadora (EO) de caráter público ou privado (podendo ser uma associação de moradores, um sindicato, um município ou outro tipo de organizaçáo sem fins lucrativos), em grupos de no mínimo 4 e no máximo 50 UH. Com exceção dos beneficiários do Grupo 3, cujo acesso poderá se dar de forma individual e ainda dos assentados de Reforma Agrária que poderão formar grupos com mais de $50 \mathrm{UH}$.

No que diz respeito à forma como se produz habitaçăo, é importante considerar que o PNHR/PMCMV faz a observação da obrigatoriedade de adotar um único regime construtivo para o grupo de beneficiários contratado, dentre os quatro modelos: mutirão assistido, regime em que os beneficiários produzem conjuntamente as unidades habitacionais com o auxílio de assistência técnica especializada (arquiteto, engenheiro, mestre de obras, pedreiro, e outros profissionais); autoconstrução assistida, em que o beneficiário, titular do contrato, produz sua unidade habitacional com o auxílio de assistência técnica especializada; administração direta, regime de construçâo em que a Entidade Organizadora (EO) é a responsável pela execuçáo das obras, empregando mão de obra do seus de funcionários; ou empreitada global, em que uma construtora é contratada para a execuçáo das obras, regime que vem ganhando importância no meio rural, talvez maiores recursos dáo apertura a novos nichos de mercado, situaçáo que não acontecia antes do Programa MCMV.

Do mesmo modo, este novo formato do PNHR exige o acompanhamento por representantes dos beneficiários na execuçáo das obras. Assim, o programa estabelece a criaçáo de uma Comissão de Representantes (CRE) formada por no mínimo três integrantes, que devem ser eleitos em assembleia registrada em ata, sendo dois eleitos dentre os beneficiários participantes do projeto e um representante indicado pela $\mathrm{EO}$. Cabe à $\mathrm{CRE}$, em todos os regimes, a gestáo dos recursos financeiros, a prestação de contas aos demais beneficiários, e a coordenação da obra (SILVA, 2014, p. 96).

Outra inovaçáo se refere ao Trabalho Social $(T S)^{26}$ que, sob responsabilidade da EO, deve ser executado nas etapas de pré-obras, obras e pós-ocupação. Para tanto, são destinados às EOs R \$ 400,00 por contrato dos grupos 1 e 2 (recursos OGU). Para os beneficiários do Grupo 3 é dispensada a execução dessas atividades de trabalho social. Sobre a Assistência Técnica (AT), deverá ser prestada pela EO por
26. Deve ser um profissional graduado nas áreas de Ciências Humanas - Pedagogia,
Sociologia, Servico social Sociologia, Serviço social
Psicologia - que possua experiência comprovada em trabalhos com comunidades ou grupos sociais. 
intermédio do responsável técnico das obras. Atualmente, o valor destinado a esse serviço em todas as regiôes do país é de $R \$ 600,00$ por unidade.

Apesar de alguns avanços do novo formato do PNHR, ainda devem ser superadas muitas questôes. Por exemplo, na possibilidade de discutir os projetos ou propor mudanças nas moradias - situaçáo muito comum nos contratos estudados -, a própria estrutura do programa desincentiva a introdução de técnicas e materiais de construção alternativos ou qualquer tipo de alteraçóes/adiçóes às casas. Estas deficiências evidenciam um programa que desconsidera não apenas as características destes núcleos familiares ou dos materiais locais, como também os diferentes tempos do modo de vida camponês, com cronogramas de obras que coincidem na época da safra, com tempos de chuva ou de descanso.

Com relação aos modelos de construção que o PMCMV Rural continua implementando, em particular a autoconstrução e o mutirāo, estes náo devem ser confundidos com o modelo de mutiráo urbano, já que, originalmente no meio rural, este processo de construçáo de moradia por ajuda mútua é derivado da espontaneidade própria de relaçôes sociais solidárias próprias destas comunidades. Não obstante, essa interação - ou melhor, a apropriação - destas antigas formas de relaçáo social com um sistema baseado em regras inadequadas ao modo de vida do público alvo termina por rebaixar os custos de reproduçáo da força de trabalho da classe trabalhadora e, consequentemente, aumenta-se a mais-valia.
5.2. Processo de construçáo nos cinco contratos do PNHR

Esta parte pretende fazer uma primeira descrição dos contratos, amparada fundamentalmente nas informaçōes coletadas dos estudos de caso escolhidos. Este retrato do processo construtivo permitiu compreender, em primeiro lugar, os eventos acontecidos no processo de produçáo a partir da entrada até a finalização do projeto, algumas das principais características dos contratos e do funcionamento do processo de produçáo a partir do observado em campo. Esta sistematizaçáo e análise dos dados levantados em campo permitiu construir uma linha de tempo de cada contrato estudado e, desta forma, representar graficamente as mudanças do cronograma inicial, confrontando-o com o cronograma real, resultante dos diferentes fenômenos (reorganização do processo construtivo, conflitos e paralizaçóes) acontecidos no processo de construção.

5.2.1. Contrato das 120 Casas (Assentamento Florestan Fernandes)

Este empreendimento localizado no assentamento Florestan Fernandes, inicialmente, era representado pelo SINTRAF/Andradina, que seria a Entidade Organizadora (EO) do contrato. Porém, este sindicato náo atendeu aos pré-requisitos exigidos pela Gerência Executiva de Habitaçáo da Caixa - GIHAB (o agente financeiro), posto que apenas organizaçóes sem fins lucrativos podem participar como EOs do PNHR. Desta forma, o representante do SINTRAF recomendou a Cooperativa Mista dos Agricultores, Pescadores, Aquicultores e Apicultores de Itumbiara/GO (COOPMAPAAI), por causa da sua experiência em projetos similares. As primeiras 103 unidades do PNHR a serem contratadas no assentamento Florestan Fernandes 
foram aprovadas pela GIHAB de Presidente Prudente/SP no dia 23 de julho de 2014. Aproximadamente quatro meses depois foram incorporadas mais 17 unidades habitacionais, totalizando 120 novas moradias.

A liberaçáo dos 15\% iniciais do recurso, utilizados na limpeza dos terrenos e preparaçáo para o início das obras, demorou mais de um ano e meio após o encaminhamento da documentação à CEF em fevereiro de 2013. Esta poderia se considerar como a primeira paralisaçấo no andamento do contrato ${ }^{27}$ - apesar de acontecer antes do início das 27. Esta longa espera pela
natura do contrato levou às amílias envolvidas a ocuparem

informaçós

conteceu em uma quarta-feir

dois dias depois, o contrato fo assinado, no dia 29 de julho $\mathrm{de}$ o recurso para único das obras.

obras, estes entraves de caráter burocrático prejudicam o processo normal do empreendimento. Esta documentaçấo era composta por: I) projeto de arquitetura e executivo; II) orçamentos; III) cronograma físico financeiro; e IV) documentos pessoais das famílias, incluindo-se a Relaçáo de Beneficiários (RB), (documento emitido pelo INCRA, utilizado para comprovar a renda das famílias ou se possuem débitos com a Receita Federal - CADIN - Cadastro Informativo de Créditos não Quitados do Setor Público Federal).

Figura 08. Moradores do construçāo de duas casas Fonte: Grupo Habis, fevereir

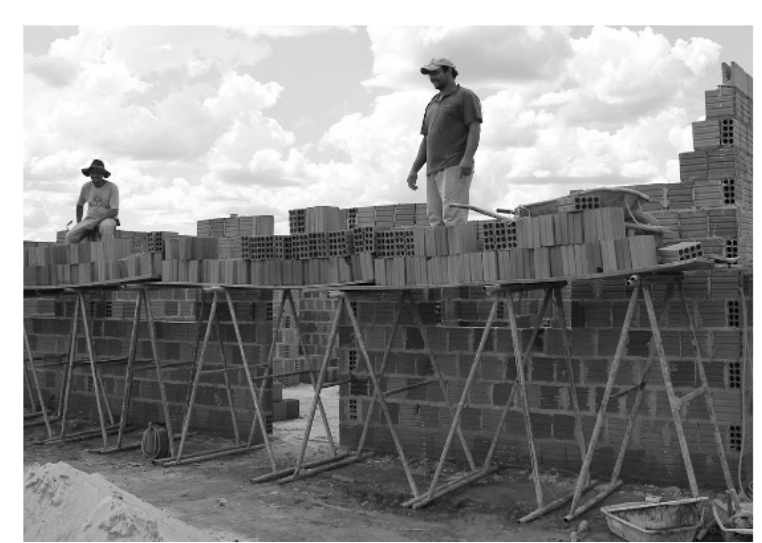

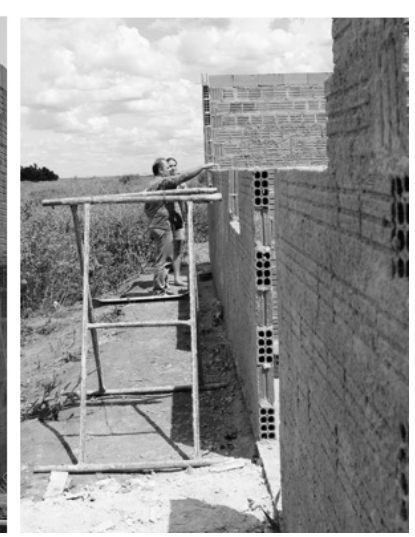

No dia 28 de novembro de 2014, acontece a segunda paralisacáo, aproximadamente três meses depois do início das obras, pois a GIHAB de Presidente Prudente havia interrompido o andamento das obras, alegando falta de recursos. O projeto foi retomado apenas no dia $13 \mathrm{de}$ janeiro de 2015. Segundo a TTS, as obras estavam previstas para serem concluídas em março de 2015 (figura 09).

Após vários meses, apresentaram-se diversos problemas com o mestre de obras. De acordo com a Trabalhadora Técnico Social, “...o trabalho não deu certo... o mestre de obras náo comparecia no assentamento e a engenheira tinha que ficar verificando parede torta". Desta forma, o representante da EO indicou a Empresa A (localizada no bairro do Butantã, no município de São Paulo), que aceitou o convite e investiu capital próprio para avançar com as obras do projeto.

Após a entrada da Empresa A, o coordenador de obra inicial foi desligado do projeto (aparentemente por desvio de recursos). Com o investimento aplicado pela empresa, o projeto foi aprovado na primeira mediçáo da CEF, que ocorreu no dia 11 de fevereiro de 2015. De acordo com a AT, esta mediçáo foi feita a partir de uma amostragem de $10 \%$ das 120 casas, e náo de 30\% das casas (ou seja, 36 unidades habitacionais), conforme as exigências da CEF. 
Figura 09. Linha do tempo do nte: Grupo Habis, 2018

\section{B LINHA DO TEMPO DO CONTRATO $(103+17$ CASAS)" \\ Legenda
$\square \quad$ Cro \\ ronograma inicial, com previsões "ideais" de finalização \\ grama real, com diferentes fenômenos: \\ Reorganizaçâa do do procosss \\ Andaments ac ao processo construtivo}

As fotos que ilustram esta Linha do Tempo fazem parte do acervo do Grupo HABIS e
correspondem ao período de fevereiro a dezembro de 2015.
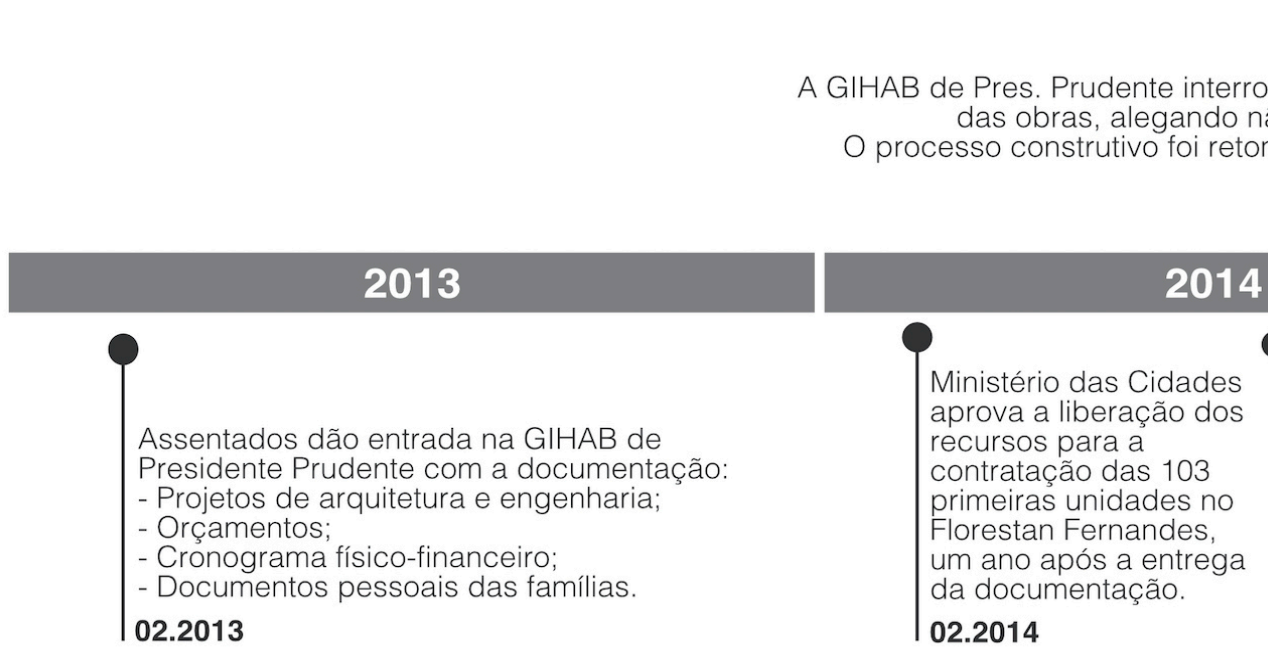

2014
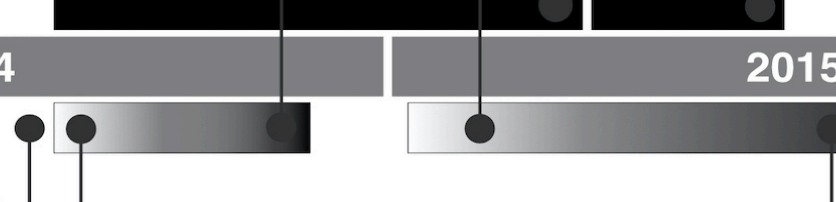

2015

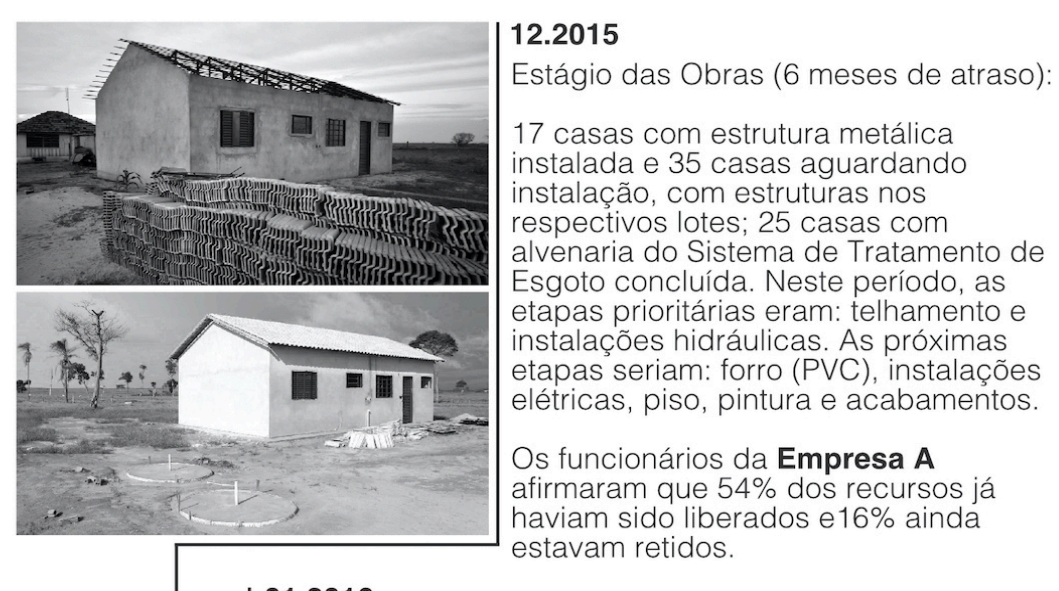

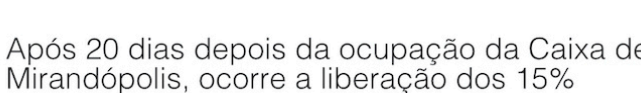

iniciais do recurso, utilizados na limpeza dos
terrenos e preparaçấo para o inicio das obras.

08.2014 - Início das obras

A demora para assinarem seus respectivos
contratos fez com que as familias

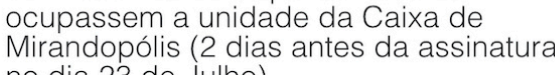

Mirandopolis (2 dias ar
no dia 23 de Julho).

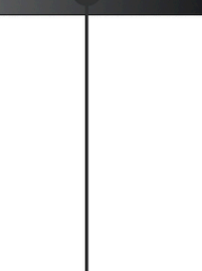

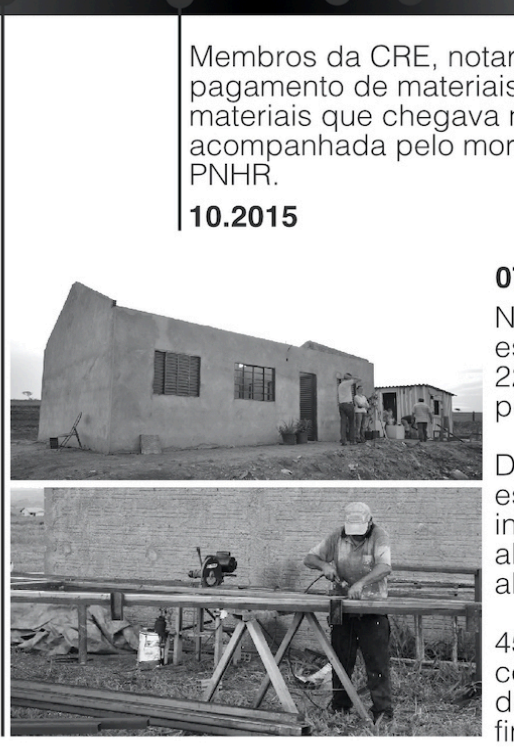

Até o final de janeiro, a previsão era de que $70 \%$ das obras estivessem concluidas, mais 3 meses para
finalizar as 1120 unidadaes. Em junho, todas as casas
estavam na etapa de pintura e instalaçăo dos vidros.

\section{6}

Amariana 
Outro aspecto fundamental eno neste empreendimento se relaciona com as modificaçôes ao projeto inicial que, segundo a TTS, devido a entrada da Empresa A e considerando o fato de a empresa ter assumido uma obra deficitária, o projeto precisou passar por um "enxugamento de recursos". Para tanto, foram feitas modificaçôes ao limite das especificaçóes mínimas da Caixa, indicadas para as casas do PNHR, relacionadas: ao revestimento cerâmico do banheiro (na área do chuveiro), que abrangia do piso ao forro, e passou a ser de até $1,5 \mathrm{~m}$ de altura; às telhas, que antes seriam cerâmicas e foram trocadas por telhas de fibrocimento; à estrutura do sistema de cobertura, que seria de madeira e passou a ser metálica; e às esquadrias, que seriam de alumínio. Além disso, o forro que seria de madeira foi mudado para PVC. A TTS e a AT destacaram ainda que todas essas modificaçóes foram propostas pelo arquiteto da GIHAB aos representantes da Empresa A, visando uma adequação no orçamento. A respeito da cobertura, a moradora entrevistada comentou durante nossa primeira conversa:

Eu náo tenho problema com telha Eternit. O único problema é a amarraçáa da estrutura com a telha. Se o serviço for bem feito (...) ja teve casas destelhadas. Náo foi problema com a telha, mas com a amarraçáo. a boca quanto ao enxugamento de recursos.

Dante da necessidade de ter um maior controle no fornecimento dos materiais de construção, a Empresa A contratou um segundo coordenador de obra, responsável por fazer todas as cotaçôes de preços e indicar o melhor fornecedor à empresa. Segundo ele, muitos materiais foram comprados diretamente dos produtores, principalmente no caso das peças cerâmicas (como telha, bloco de tijolo) e do cimento que, segundo o coordenador 2, "fizemos a cotação e vimos que valia a pena ir buscar numa cidade mais distante, diretamente do fornecedor, evitando os intermediários".

Segundo o coordenador 2, era a Empresa A (com o aval da Comissão de Representantes) quem contratava os pedreiros e fazia o pagamento dos trabalhadores (muitos do próprio assentamento). Assim como os trabalhadores contratados, o coordenador 2, a TTS e a AT também não possuíam carteira assinada com seus respectivos contratantes (Empresa A e COOPMAPPAI). Segundo eles, seus contratos de trabalho estavam restritos à assinatura de um termo de compromisso.

Este projeto habitacional apresentou inúmeros problemas desde o seu início, desdobrando-se em diversas alteraçóes no seu gerenciamento. Durante a primeira viagem, o coordenador 2 informou que 17 casas que estavam com a etapa de alvenaria completa haviam caído por completo, em decorrência do vento (figura 10).

Figura 10. Problemas em 17 casas pela
ação do vento
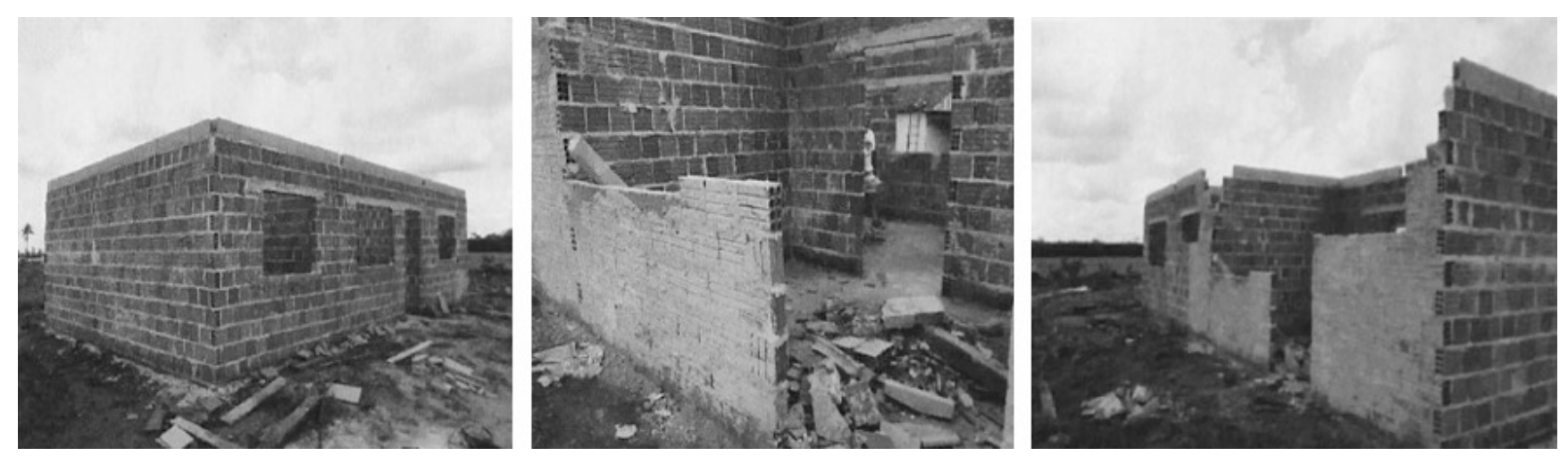

Fonte: Grupo Habis, fevereiro 
Após problemas com a compra de materiais (superfaturamento das notas de materiais de construção, provocando um desvio de $R$ \$ 100 mil do projeto), a Empresa A dispensou o coordenador 2. A dívida, ao todo, desde o início do projeto, chegava a quase $\mathrm{R} \$ 350$ mil (somando-se máo de obra e material de construção). Segundo o coordenador 3 (funcionário da Empresa A), em dezembro de 2015, a Empresa A concordou em assumir a dívida referente à mão de obra, estipulada em R\$ 70 mil. Para ele, "o PNHR dá dinheiro, mas essa obra aqui, năo; nós queremos ganhar dinheiro, náo somos uma instituiçáo de caridade".

Em dezembro de 2015, já com seis meses de atraso da segunda previsão de término das obras (junho de 2015), havia 17 casas com estrutura metálica instalada e 25 casas com alvenaria do Sistema de Tratamento de Esgoto concluída. O coordenador 3 afirmou que as etapas prioritárias eram o telhamento e as instalaçōes hidráulicas. As próximas etapas seriam o forro (PVC), as instalaçóes elétricas, o piso, a pintura e os acabamentos. A previsão era de que, para o final de janeiro de 2016, $70 \%$ das obras estivessem concluídas e precisariam três meses adicionais para finalizar as 120 unidades habitacionais.

5.2.2. Contrato das 44 Casas (Assentamento Florestan Fernandes)

Com relaçáo ao segundo contrato habitacional desenvolvido no assentamento Florestan Fernandes, 44 famílias foram organizadas pela Associação Comunitária Regional de Ação Social Hebert de Souza, cuja sede está localizada no município de Andradina. Estas 44 famílias foram divididas em 05 grupos, representados por 05 Comissōes de Representantes (CRE), cada uma com 02 integrantes. O critério utilizado para a divisão destes grupos levou em consideraçáo a proximidade entre os lotes.
Inicialmente, as famílias tinham optado pelo mutirão. Porém, segundo informaçóes de uma moradora entrevistada, ficaram sabendo que muitos assentamentos tiveram problema com esta modalidade e, por isso, embora a AT náo concordasse com a entrada da empresa, as 44 famílias aprovaram, em assembleia em abril de 2014, a contrataçáo da Empresa B para a execuçāo do projeto.

A liberaçáo dos primeiros $15 \%$ do recurso aconteceu em janeiro de 2015 e já em fevereiro as 44 casas estavam na etapa de fundação (figura 12). O proprietário da Empresa B alterou o projeto de fundaçáo das casas propondo, ao invés do radier, vigas baldrame com 15 estacas cilíndricas, cada uma com $20 \mathrm{~cm}$ de diâmetro e $3 \mathrm{~m}$ de profundidade. Também foi proposto que todas as casas tivessem laje convencional (figura 11). Segundo ele, a empreita teve um custo total de $\mathrm{R} \$ 90 \mathrm{mil}$ (material e MO). Na sua avaliaçấo, seu maior lucro seria extraído do recurso utilizado na execuçáo das lajes que, assim como as fundaçôes, foram construídas com concreto usinado, fornecido por uma empresa de Birigui. Nessa época, os serventes estavam recebendo $R \$ 60,00$ por dia trabalho, enquanto os pedreiros recebiam $\mathrm{R} \$ 100,00$. Para a moradora entrevistada, "não dava pra pagar mais do que isso". Segundo ela, a AT propôs um valor menor para a remuneração destes trabalhadores: $\mathrm{R} \$ 20,00$ o dia do servente e $\mathrm{R} \$ 40,00$ o dia do pedreiro.

A moradora entrevistada acompanhava a Empresa B com as cotaçóes junto aos fornecedores e era ela quem recebia todas as entregas de materiais no canteiro. "Se algum material está deteriorado ou a quantidade for inferior à encomenda, a CRE náo assina as notas fiscais". O mestre de obras contratado (sem registro de carteira) é de 
Valparaíso, SP, e já havia trabalhado na Prefeitura do município em um mutirão da $\mathrm{CDHU}$ há uns 04 anos. $\mathrm{O}$ irmão dele, que é morador do assentamento Florestan Fernandes, indicou o trabalho para ele.

Figura 11. Fundaçốes das casa (estacas cilíndricas e vigas
baldrame): laje de concreto.

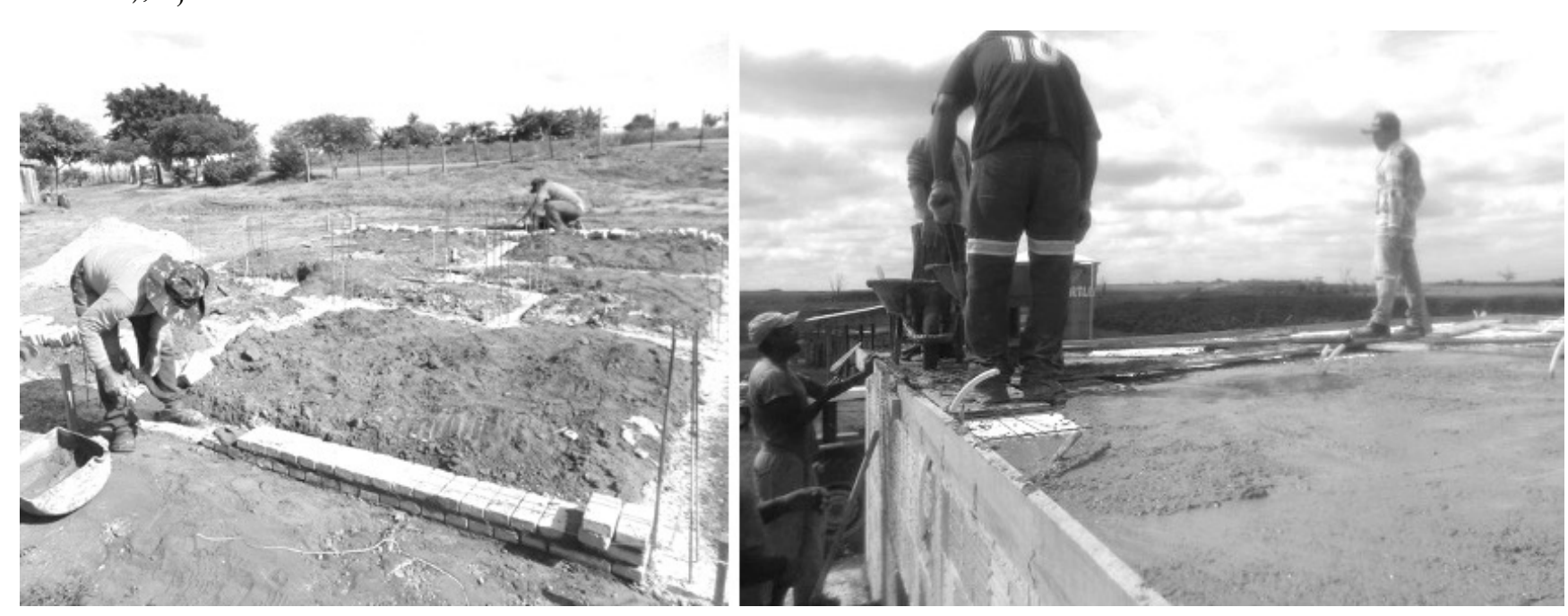
Fonte: Empresa B, fevereiro de
2015

$\mathrm{Na}$ terceira viagem conversamos de novo com a moradora que acompanhava a empresa na cotaçáo de materiais. Segundo ela, nesse mesmo dia teve uma reuniáo com a finalidade de obter esclarecimentos quanto ao valor de $\mathrm{R} \$ 130$ mil, solicitado pela Empresa B, para o pagamento de mão de obra. Ela achou o valor alto, pois, em geral, eles vinham solicitando valores em torno de $\mathrm{R} \$ 60 \mathrm{mil}$ a $\mathrm{R} \$ 70$ mil para esta finalidade. O mestre de obras informou que o valor disponibilizado para o pagamento da máo de obra, por unidade, seria de R $\$ 10$ mil. No entanto, neste período, já haviam sido gastos, por casa, quase $\mathrm{R} \$$

$19.270,00$ com o pagamento dos serviços das etapas construtivas previstas.

Para início de dezembro de 2015, já com 7 meses de atraso com relação à previsão inicial (figura 12), havia 44 casas cobertas e com janelas instaladas, 13 casas com gesso até o teto, 10 casas com piso instalado e 20 casas com pintura externa concluída. Porém, a GIHAB havia interrompido a liberaçāo de recursos. A última liberação ocorreu no dia 04 de dezembro.

A respeito do andamento das obras depois de vários meses da última viagem de campo, a Assistente Técnica confirmou a saída da Empresa B, por múltiplos problemas, e a entrada da Empresa A, que assumiria as obras das 44 casas até 2017. 
Figura 12. Linha do tempo do te: Grupo Habis, 2018

\section{B LINHA DO TEMPO DO CONTRATO (44 CASAS)*

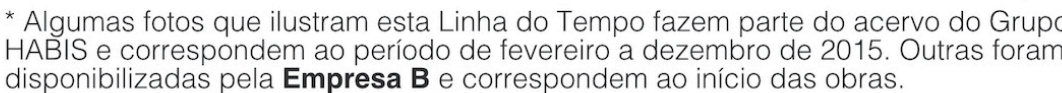

Legenda

a real, com diferentes fenômenos:

Confilitos e paralizaçōes

Andamento normal da obra

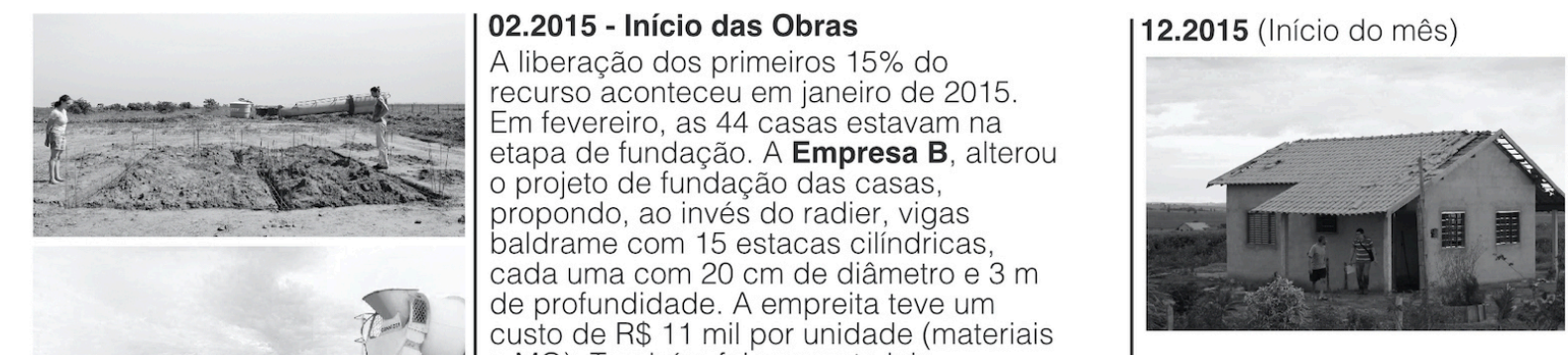

Estágio das Obras $(7$ meses de
atraso com relaçăo à previsão

inicial):

1 casas com gesso até o teto;
10 casas com piso instalado;
0 casas com pintura externa

O morador do lote 135 (representante da CRE) e o morador
do lote 129 abriram processo contra a Empresa B.

A GIIHAB havia interrompido a liberação de recursos. A última

| 12.2015 (Fim do mês

Segunda previsão de conclusão das obras.
2013

As 44 familias aprovaram, em assembleia, a entrada da Empresa B Bo
projeto seu representante fez um contrato individual com cada um projeto, seu representante fez um contrato individual com cada um
delas. No item referente à remuneracão, consta no contrato o seguint para
para CONTRATADO qualquer quantia de dinheiro que sobre do valur
citado acima
2014
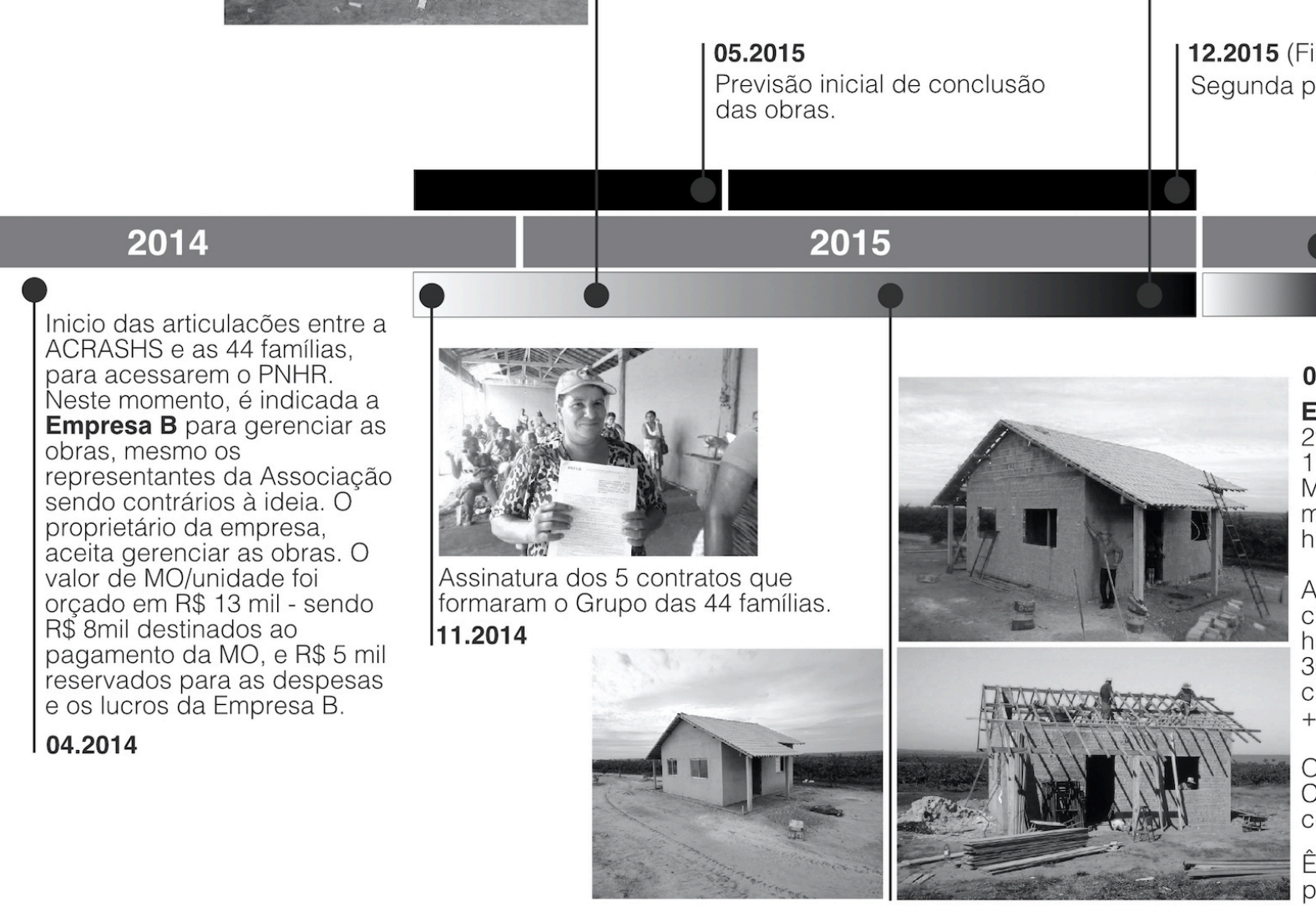

\section{6}

07.2015

stágio das Obras:

(n)

idráulicas e fios elétricos.

GIHAB já havia feito duas mediçōes e, com
anco meses de obra. $85 \%$ dos recursos sa Thiam sido liberados, em três parcelas: $15 \%$ + morador do lote 135 e também membro da CRE, já havia decidido construir sua casa por
conta própria, por não confiar na Empresa nio (mestre de obras) foi desligado do projeto
elo 
5.2.3. Contrato das 26 casas (Assentamento Boa Esperanca)

Após a aprovação da Portaria Interministerial N. 78 pelo Ministério das Cidades, os representantes da FETAESP iniciaram um processo de negociação com o Banco do Brasil, visando o acesso aos recursos do PNHR para os beneficiários do Programa Nacional de Crédito Fundiário (PNCF). As tentativas sem sucesso junto a este agente financeiro fizeram com que os membros da federaçáo recorressem à Gerência Executiva de Habitação da Caixa (GIHAB), de Presidente Prudente. Assim, em fevereiro de 2014, juntamente aos documentos técnicos, os beneficiários do Crédito Fundiário também providenciaram: a Declaraçấo de Aptidáo ao PRONAF (DAP), por meio da qual a Caixa verifica a renda bruta anual das famílias assentadas pelo Crédito Fundiário; a declaraçấo do ITESP informando o não recebimento pelo possível beneficiário de financiamento habitacional anterior; e a matrícula do imóvel, comprovando a venda da antiga propriedade, bem como a titularidade particular dos lotes dos respectivos assentados.

Após cinco meses de análise dos documentos enviados pela FETAESP em 31 de julho de 2014, a GIHAB de Presidente Prudente aprova a contrataçáo de 26 unidades no assentamento rural Boa Esperança, na modalidade "autoconstrução assistida". Este seria o primeiro contrato do PNHR organizado pela FETAESP no estado. Neste momento, a participaçáo da Empresa $\mathrm{C}$ já havia sido indicada à FETAESP pela Confederaçáo Nacional dos Trabalhadores na Agricultura Familiar (CONTAG). A empresa, cuja sede está localizada no estado do Espírito Santo, foi fundada em 2009 por um engenheiro civil recém-formado e seu objetivo com a empresa era disputar a produçáo habitacional no município de Vitória via Programa Minha Casa, Minha Vida (PMCMV). As dificuldades de inserção na produção habitacional urbana do programa fizeram com que o foco da empresa fosse direcionado para a área rural. Para tanto, foi fundada, inicialmente, uma construtora e, em seguida, uma incorporadora especializada em consultoria e desenvolvimento de projetos. A Empresa C, portanto, é resultado da fusão de uma construtora e de uma incorporadora, que atua tanto no mercado imobiliário nacional, quanto em projetos do PNHR.

As atribuiçôes da Empresa C seriam: a elaboraçáo dos projetos arquitetônico, executivo e do cronograma físico-financeiro; a cotaçáo e compra de materiais, além de organizar a logística de distribuição dos materiais nos canteiros; a contrataçáo e o pagamento dos operários da construçáo; a elaboração das Planilhas de Levantamento de Serviços; e a fabricação de componentes pré-moldados. Desta forma, cinco meses após a aprovação (novembro de 2014), foram iniciadas as obras das 26 casas (figura 13).

Decorrido mais de $50 \%$ da obra, a concessionária responsável pela instalaçấo da rede de energia elétrica no assentamento ainda estava terminando de executar a conexáo entre os postes e o padráo de entrada das casas. No que diz respeito ao abastecimento de água, o assentamento possui quatro poços semi artesianos. Neste período, o assentamento ainda não contava com rede de água e energia. 
Figura 13. Linha do tempo do Fonte: Grupo Habis, 2018

\section{B LINHA DO TEMPO DO CONTRATO (26 CASAS)*}

As fotos que ilustram esta Linhad do Tempo fazem parte do acervo do Grupo HABIS e
correspondem a por periodo de julho de 2015 ajunho de 2016 .

Legenda

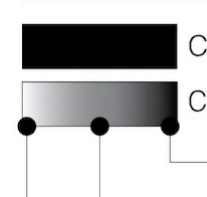

Cronograma inicial, com previsōes "ideais" de finalização

nograma real, com diferentes fenômenos:

Conflitos e paralizaçōes

processo construtivo

mento normal da obra
07.2015 - Estágio das obras
periodo, o assentamento ainda

nẫo contava com rede de água e
energia. No canteiro, havia dois pedreiros trabalhando no reboco
alvenaria das casas. Para o preparo
massa, a Empresa c disponibilizou un
betoneibiza zu um
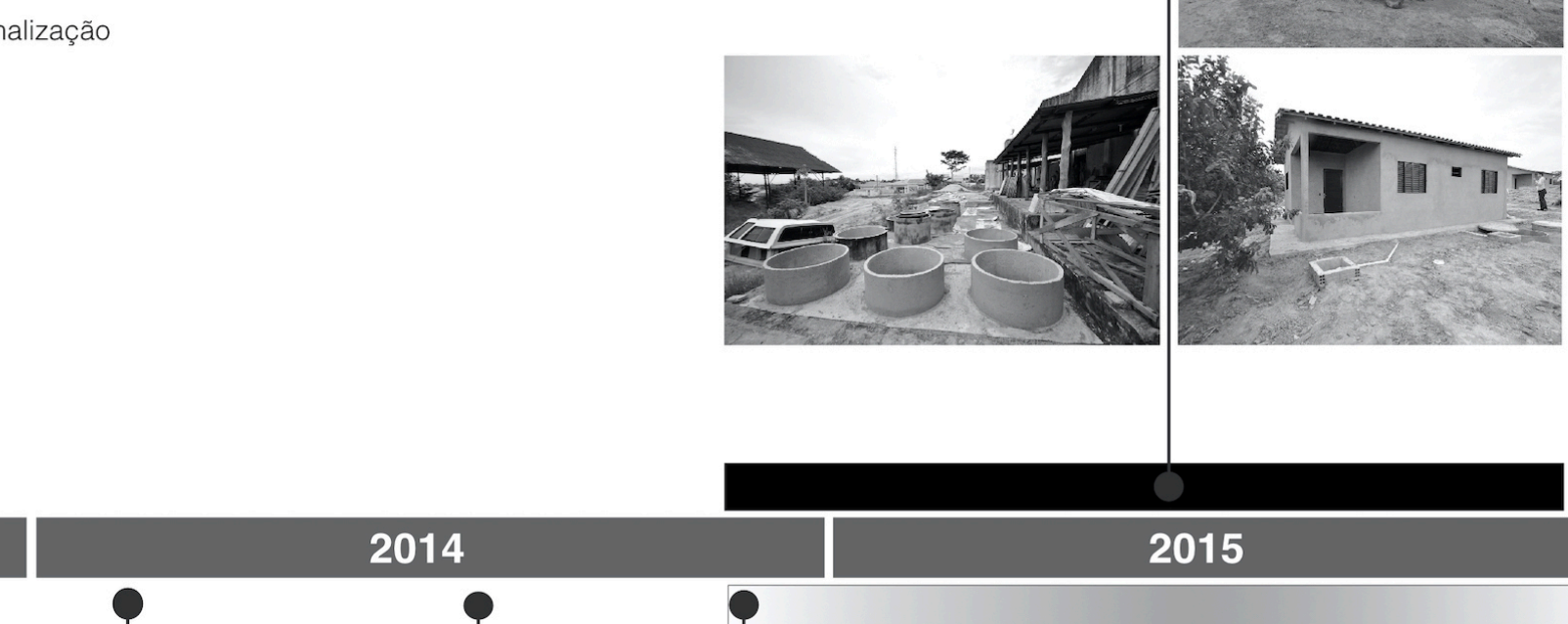

Após a aprovação da Portaria Interministerial N. 78*, pel
Ministeŕiio das Cidades, os representantes da FETEES

visando o acesso aos recursos do PNHR para os beneficiários

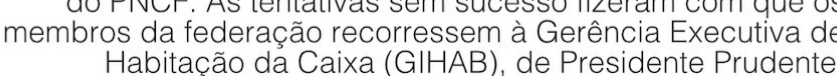

Além dos documentos técnicos, os beneficicários do Crédito
Fundiário também providenciaram:

- Declaração do ITESP informando o não recebimento de

financiamento habitacional anterior;
- Matrícula do imóvel.

Art. $1^{\circ}$ Ficam incluídos os agricultores familiares
beneficiários do Programa Nacional de Reforma

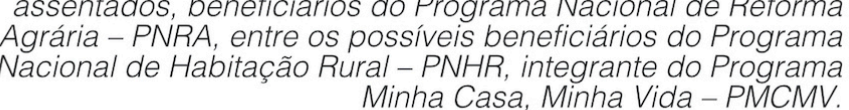

2014

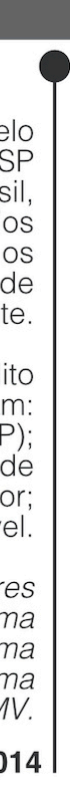
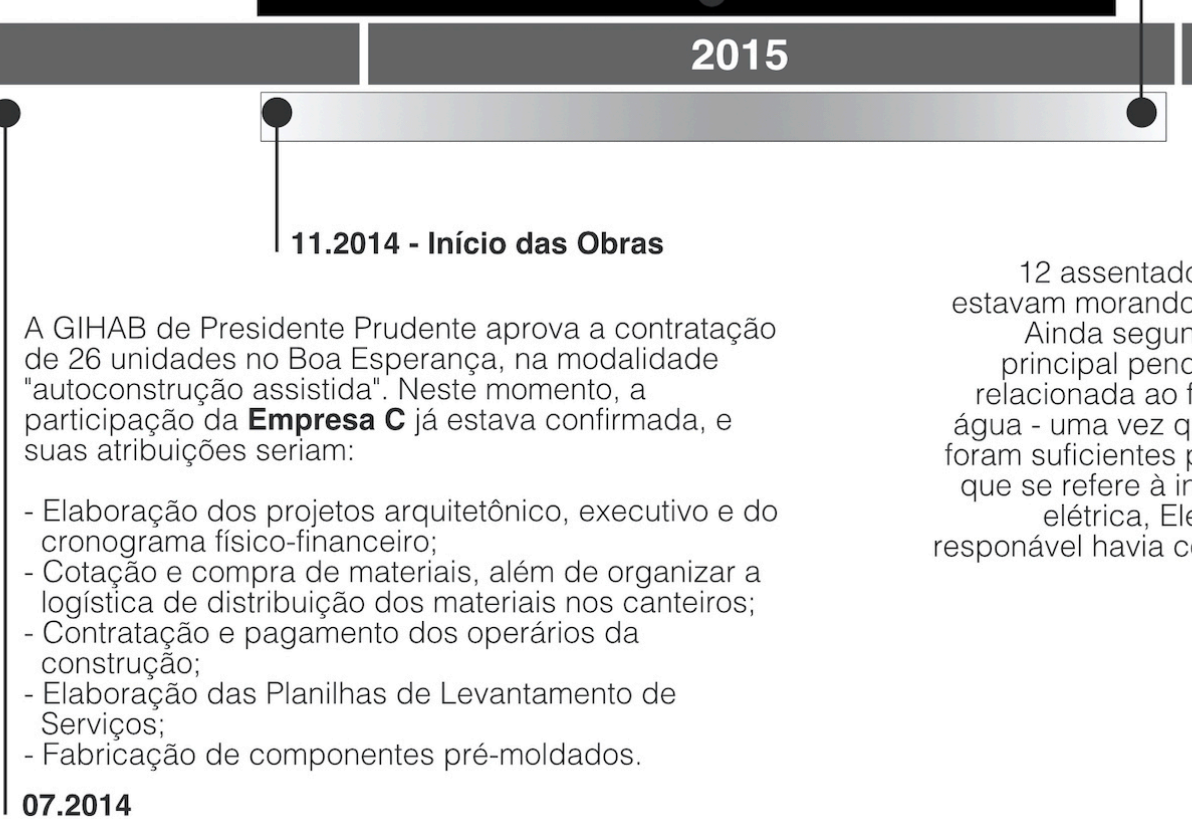

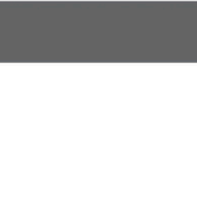

12 assentados, beneficiários do PNHR, já
estavam morando em suas respectivas casas.
Ainda segundo o representante da EO,

2016

acordo com informaçōes fornecidas pelo
poresentante da EO, o contrato das 26 casas havia extrapolando um mês do cronograma inicialmente
previsto.

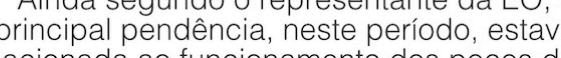
rélacionada ao funcionamento dos poços oram suficientes para cobrir esta despesa. No
que se erefer a instalaçấ da redede energia
elétrica Ele disse que a concessionaria responável havia concluído o serviço em ma $\mathrm{ma}$ 
Um fator que chamou a atençáo estava relacionado ao galpão da empresa, localizado na área urbana do município de Pacaembu (Figura 14). O espaço foi alugado pela Empresa $C$ exclusivamente para gerenciar os empreendimentos em andamento no estado de Sáo Paulo, servindo como área para estoque de materiais, pré-fabricaçáo de componentes e escritório (com 15 funcionários contratados para acompanhar os empreendimentos em andamento). Assim, foi possível observar que a relaçấo de materiais construtivos empregados nos empreendimentos gerenciados pela empresa eram todos certificados pelo programa, seguindo os critérios estabelecidos pelo Programa Brasileiro da Qualidade e Produtividade do Habitat (PBQP-H).

Figura 14. Fachada do galpáo
vista interna do galpăo da Empresa $\mathrm{C}$ com algun

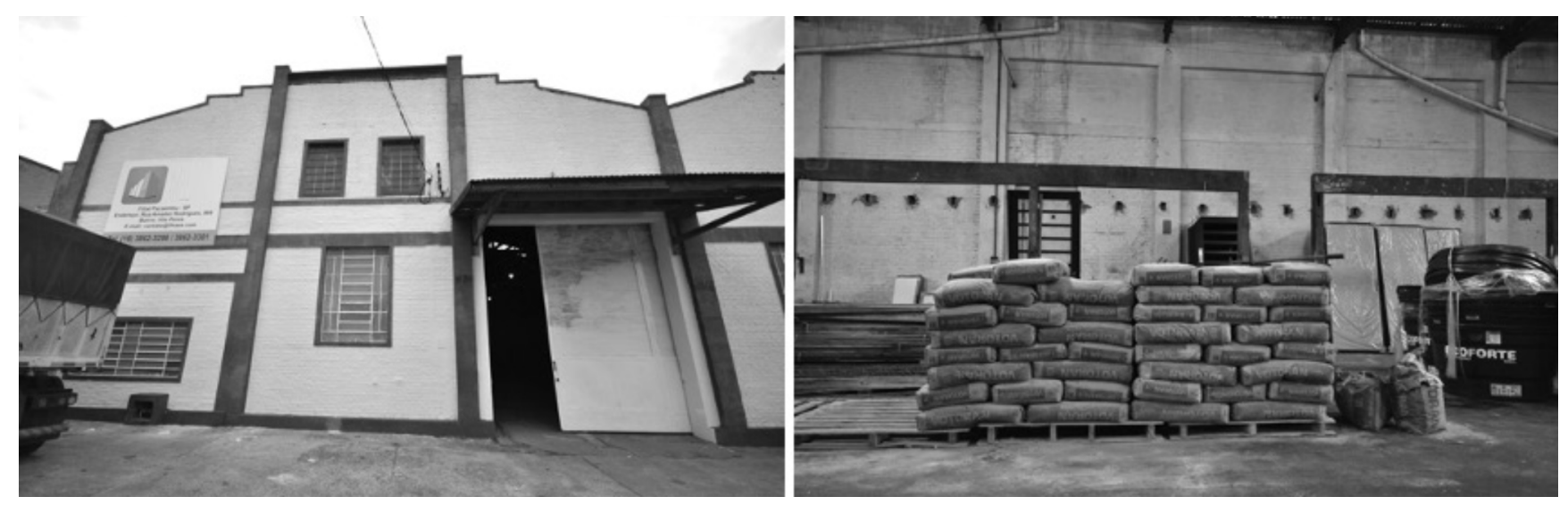

Fonte: Grupo Habis, fevereiro

De acordo com informaçôes fornecidas pelo representante da EO, o contrato das 26 casas havia sido concluído no dia 28 de dezembro de 2015, extrapolando um mês do cronograma inicialmente previsto pela Empresa C e do período de obras recomendado pela GIHAB de Presidente Prudente. Em junho de 2016, 12 assentados, beneficiários do PNHR, já estavam morando em suas respectivas casas.
5.2.4. Contrato das 27 casas (Assentamento Dona Carmem)

Além dos contratos aprovados nos assentamentos Florestan Fernandes e Boa Esperança, a GIHAB de Presidente Prudente havia aprovado também, no dia 14 de novembro de 2014, um quarto contrato do PNHR em outro assentamento rural da Região Oeste do estado. Este contrato de 27 unidades habitacionais está localizado no assentamento de reforma agrária Dona Carmem, na divisa entre os municípios de Mirante do Paranapanema e Teodoro Sampaio, pertencentes à Regiáo Administrativa de Presidente Prudente. Estas 27 famílias estão organizadas pela COOPPAF, cooperativa que surge em abril do 2013 , liderada por um morador do assentamento Roseli Nunes, localizado em Mirante do Paranapanema. A Cooperativa contava, naquela época, com 30 assentados cooperados do Dona Carmem.

A Empresa D, responsável por gerenciar o processo construtivo das 27 casas do PNHR no assentamento, está localizada no município de Mirante do Paranapanema. Esta empresa surgiu em 2013, passou a trabalhar com empreendimentos urbanos do PMCMV em Mirante do Paranapanema, São Paulo, Euclides da Cunha e, também, no estado do Paraná. Em Mirante, trabalham apenas com projetos residenciais. Segundo um dos seus representantes, trabalhar só com empreendimentos do PNHR não compensa.

A Empresa D entregou a documentaçáo na GIHAB de Presidente Prudente. A princípio, 30 famílias do assentamento foram organizadas para acessar o PNHR. Após análise do agente financeiro, 3 famílias foram excluídas (por possuírem imóveis registrados em seus nomes e já terem sido contempladas com subsídios da $\mathrm{CDHU}$ ). O projeto foi aprovado pela GIHAB no dia 14 de novembro de 2014 e depois 
Figura 15. Linha do tempo do te: Grupo Habis, 2018

\section{B LINHA DO TEMPO DO CONTRATO (27 CASAS)* \\ As fotos que ilustram esta Linha do Tempo fazem parte dos acervos da Empresa D e
do Grupo HABIS e correspondem ao perído de marco a dezembro de 2015 .}

\begin{tabular}{l} 
Legenda \\
\hline \\
\hline$\quad \ldots \quad$
\end{tabular}

Conograma inicial, com previsões "ideais" de finalização

grama real, com diferentes fenômenos:

Conflitos e paralizações

construtivo

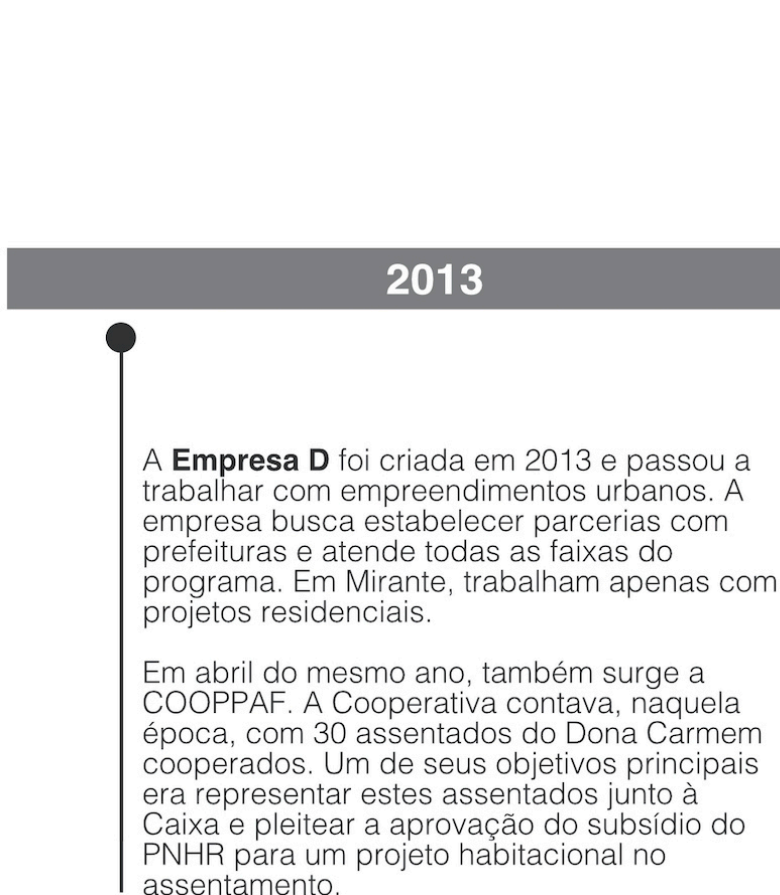

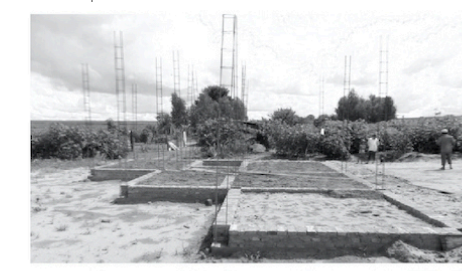

03.2015 - Início das obras

A Empresa D contratou um morador

COOPPAF, como mestre de obras

outros pedreiros - a maioria do Dona
Carmem.

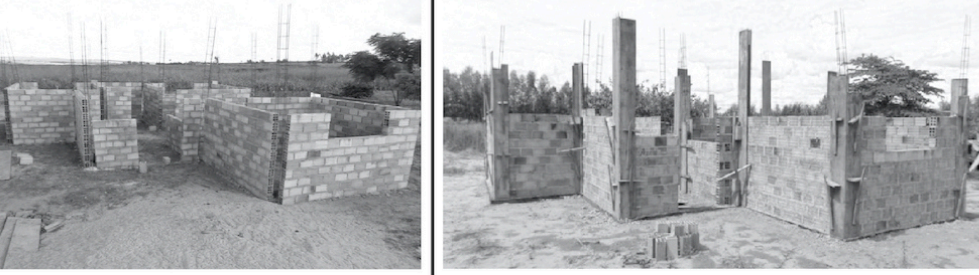

Cronograma inicial de

Março a Agosto de 2015

2014

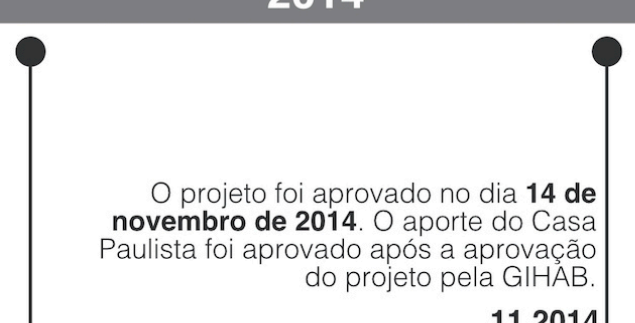

\section{$\mid$}

11.2014

A Empresa D entrega a documentacãa na GIIIAB de
Presidente Prudente. A princíioio, 3 tamilias do

assentamento oram organizadas para acessar o PNHR.
Após análise dos do agente financeiro, 3 familias foram excluidas por possururem imóveis registrados em seus
nomes e já terem sido contempladas com subsídios da

Inicialmente, foram elaborados dois projetos arquitetônicos
$70 \%$ das familias queriam 3 quartos. Segundo ele, a GilHA
recomendou acessibilididade para todos os assentados.

03.2014

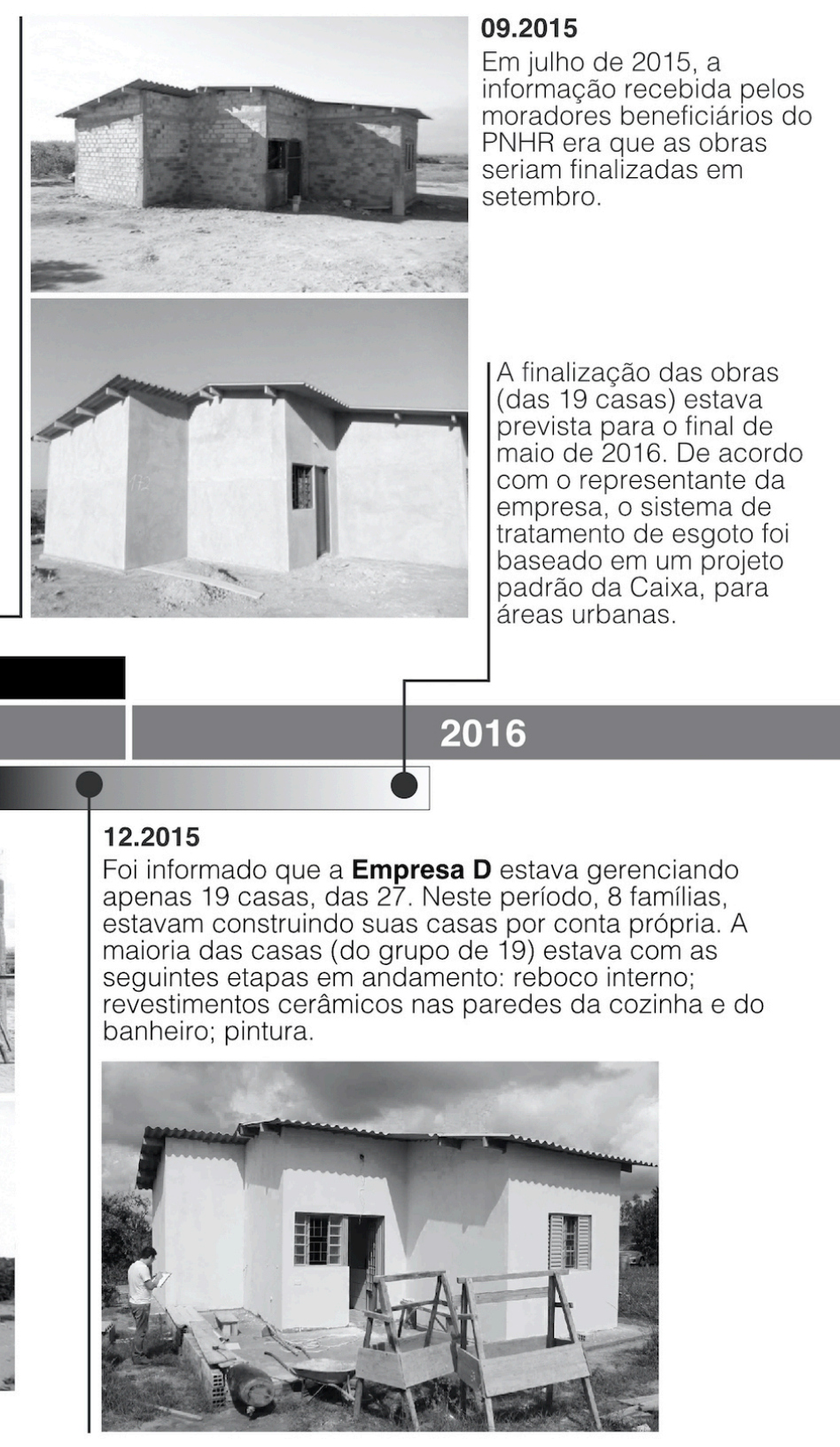

109 
A finalizaçáo das 19 casas estava prevista para o final de maio de 2016.

Segundo o representante da Empresa D, inicialmente, foram elaborados dois projetos arquitetônicos, já que $70 \%$ das famílias queriam 3 quartos. Posteriormente, com o aporte de recursos, os profissionais da Empresa D alteraram o projeto inicial, acrescentando mais um quarto. Segundo o representante da empresa, a GIHAB recomendou acessibilidade para todos os assentados.

Em março de 2015, foi iniciada a obra, com previsăo inicial de finalizar em agosto de 2015. A Empresa D, como responsável pelo acompanhamento das 27 casas aprovadas, contratou um morador do assentamento Roseli Nunes e membro da COOPPAF como mestre de obras. Ele se responsabilizou por contratar outros pedreiros - a maioria do Dona Carmem.

Segundo informaçôes recebidas por alguns moradores beneficiários do PNHR, as obras seriam finalizadas em setembro. Porém, a Empresa D estava gerenciando apenas 19 das 27 casas. Em dezembro de 2015, essas 19 unidades ainda estavam na etapa de reboco e revestimentos cerâmicos nas paredes da cozinha e do banheiro. Neste período, as restantes 8 famílias estavam construindo suas casas por conta própria.

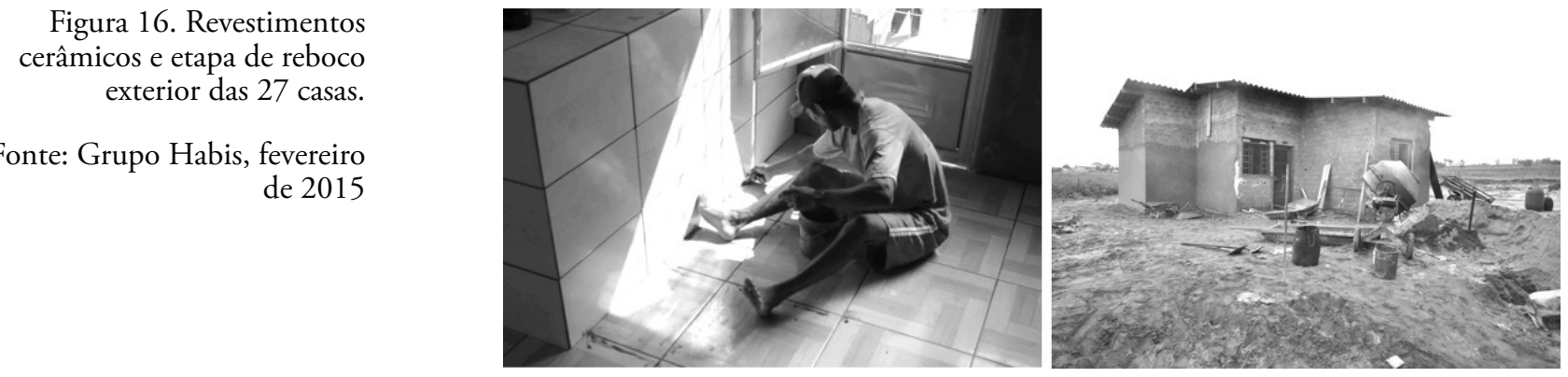
De acordo com o representante da Empresa D, o sistema de tratamento de esgoto foi baseado em um projeto padrão da Caixa (para áreas urbanas). A adaptaçáo para o assentamento não funcionou. Estavam contando com recursos da modalidade "reforma" para refazer esta etapa, que ficou inacabada.

No gráfico comparativo (figura 17), foi possível compreender as mudanças do cronograma inicial com o cronograma real destes quatro contratos estudados. Assim, fica evidente que a estratégia de centralizar os equipamentos, o estoque de materiais e gerenciamento em um único local e; produzir diversos tipos de componentes em série, permitiu otimizar a construçáo das unidades no contrato das 26 casas, fato que se reflete no cronograma do empreendimento. Caso oposto acontece no contrato das 120 casas, no qual resultante dos diferentes fenômenos acontecidos no processo de construçāo, produto das condiçóes próprias destes canteiros; a ausência de infraestrutura; o recorte de recursos, paralisaçôes e conflitos internos, e; a mesma reorganização do processo construtivo, terminou prejudicando a produçấo, com atrasos de mais de um ano do cronograma inicial.

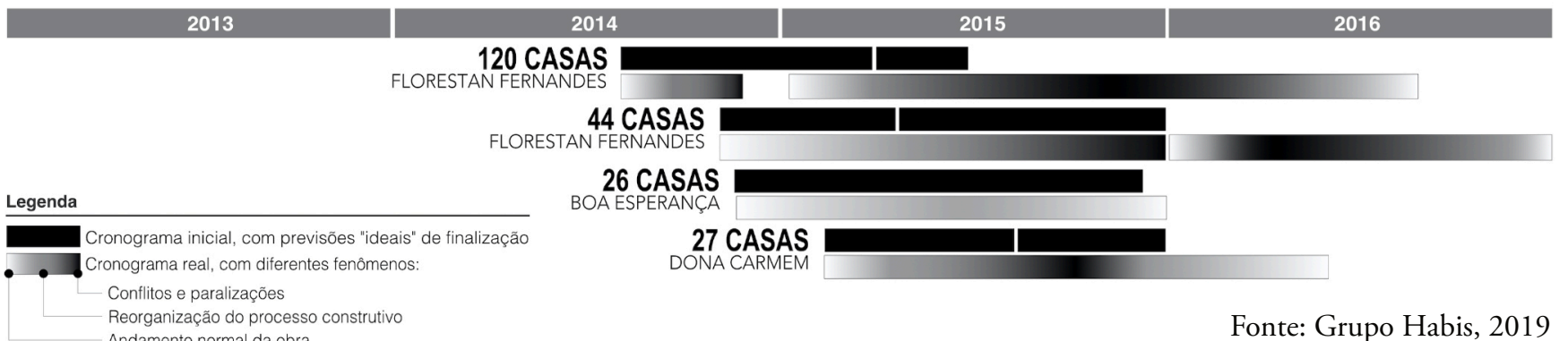


6. As EOs e o lugar da empresa construtora

Durante a primeira ida ao assentamento e ao escritório da Empresa D, realizada em julho de 2015, fomos informados por algumas famílias do assentamento, e também pelos representantes da empresa que, além do contrato de 27 casas, 10 famílias do assentamento Dona Carmem também já haviam sido contempladas com recursos do PNHR na modalidade construção. Estas 10 casas, que não constavam nas primeiras planilhas enviadas pelo INCRA e pela Caixa/Brasília, foram, de fato, as primeiras unidades do PNHR construídas em assentamentos rurais do estado de SP.

Este segundo contrato do PNHR no assentamento, também aprovado pela GIHAB/Caixa de Presidente Prudente no dia 10 de dezembro de 2014, foi organizado pela Associaçáo de Produtores Nova Conquista de Mirante do Paranapanema, cujo representante, morador do lote 31, está no assentamento há 07 anos e é antigo beneficiário do Crédito Instalaçáo, do INCRA. Para gerenciar as obras, foi escolhido pelo representante da associaçáo um jovem engenheiro de Teodoro Sampaio, que já havia trabalhado como estagiário em dois empreendimentos do Minha Casa, Minha Vida, um em Presidente Prudente e outro em Teodoro Sampaio.

Para o desenvolvimento dos projetos, a Empresa E, localizada no centro de Teodoro Sampaio, contratou um engenheiro, que elaborou três versōes do projeto arquitetônico para serem apresentados na GIHAB/ Caixa que, após avaliaçáo, aprovou apenas dois modelos, com o mesmo orçamento, denominados "projeto 3" "projeto 5". Em julho de 2015, a construção das 10 casas já havia sido concluída.
Partimos aqui da expectativa de que o PNHR (integrante do Programa MCMV) não necessariamente tem como foco principal responder ao problema do déficit habitacional - digo isto, pois seu caráter residual não permitiria atender a esta meta -, e sim sob a responsabilidade dos movimentos sociais ou das chamadas Entidades Organizadoras (EOs) seriam enos fortes incentivos à participaçáo das famílias em todas as etapas do processo de produção habitacional e, consequentemente, o fortalecimento do movimento e de suas relaçóes com a população, a redução das condiçóes de pobreza e desigualdade acentuadas nestes contextos e o aumento da qualidade das moradias produzidas.

Neste sentido, cabe às EOs um grande conjunto de atribuiçôes. Em termos gerais, elas estão desenhadas para organizar e apoiar as família no desenvolvimento de todas as etapas do projeto habitacional, ou seja, devem se responsabilizar pelo encaminhamento aos Agentes Financeiros do PNHR, os projetos de arquitetura, de engenharia e do Trabalho Social, a documentação das propriedades ou dos terrenos e a documentaçáo dos beneficiários para fins de participaçấo no Programa; o gerenciamento de obras, responsabilizando-se pela sua conclusão; e a contrataçấo e a articulaçáo com os responsáveis pelos trabalhos de Assessoria Técnica (AT) e Trabalho Técnico-Social (TTS) dos projetos. Segundo este, espera-se que estas tarefas sejam feitas sempre em interação com as famílias beneficiárias.

Cabe destacar que, como mencionado anteriormente, as disposiçôes do Programa Nacional de Habitação Rural (PNHR) estabelecem que estas EOs podem escolher um único regime de construçáo para o 
empreendimento, dentre as seguintes alternativas: 1) Autoconstruçáo assistida; 2) Mutirão assistido ou autoajuda assistida; 3) Autogestão com administraçấo direta; e 4) Empreitada global. Como consta nos contratos dos empreendimentos estudados, o regime construtivo adotado pelas EOs foi a autoconstruçáo assistida. Sobre este aspecto ainda com algumas expectativas sobre o papel das EOs -, Bonduki destaca o papel da autogestáo enquanto mecanismo de empoderamento comunitário, ao definir a autogestáo como um processo no qual:

Os futuros moradores organizados em associaçóes ou cooperativas, administram a construçáo das unidades habitacionais em todos os seus
aspectos, a partir de regras e diretrizes estabelecidas pelo poder público, quando este participa financiando o empreendimento Seria uma organizaçáo autônoma da sociedade civil que, com o apoio e o financiamento do poder público, equaciona a produçáo de moradias com a participação dos moradores e a introduçăo de avanços tecnológicos e
sociais que só o trabalho coletivo pode propiciar (Bonduki, 1992: 18-19).

Náo obstante, um aspecto que precisa ser considerado diz respeito ao reconhecimento do "ideário" da autogestâo entre as organizaçôes e os movimentos que atuaráo como entidades organizadoras. Parte das organizaçôes que atuam no PNHR demonstram trazer, como parte de seu repertório, as práticas associadas à autogestão, como é, por exemplo, o caso do papel ativo da Cooperhaf e da ampla experiência na autoconstrução habitacional no âmbito PNHR/PMCMV. De outro lado, outras entidades que, apesar de sua atuaçáo na luta pela terra $\mathrm{e}$ pela reforma agrária, não têm demonstrado muito interesse na participaçáo do campesinato na produçáo habitacional como forma de fortalecer a organizaçáo popular. Nesse caso, o risco é de que sua atuação acabe sendo muito próxima a ação das construtoras, cujo propósito é produzir moradias, sem considerar a participação popular associada à conquista da moradia digna.

Como já foi mostrado no item anterior, as EOs dos cinco contratos estudados optaram como estratégia para "solucionar" os problemas de gestáo em canteiro e falta de recursos, alterar a forma de construir, na qual uma construtora assume toda a obra sob a direçáo da entidade e a coordenaçấo da Comissão de Representante do Empreendimento (CRE). Isto traz como resultado um regime híbrido entre autoconstrução e empreitada global.

Inicialmente, a estrutura para articulação, aprovação e início das obra no contrato das 120 casas estava composta pela responsável pelo Trabalho Técnico-Social (TTS) com formação em Pedagogia (conforme exigências do programa) e pela Assessora Técnica (AT) engenheira e moradora do assentamento rural União, localizado no município de Guarani D’Oeste (estas duas profissionais se mantiveram até o final). Também para cumprir funçōes diretamente no canteiro o controle financeiro e a compra de materiais, dentre outras atividades, a COOPMAPPAI contratou um coordenador de obras (que já trabalhava em outras obras da Cooperativa em Sergipe) e um mestre de obras, externo ao assentamento, encarregado responsável pela fiscalizaçâo. Porém, após múltiplos problemas depois do início das obras que, segundo a AT, relacionavam-se com o mestre de obras e o mesmo regime de autoconstruçáo assistida, o representante da EO procurou a Empresa A para assumir o processo de produçáo das unidades e, inclusive, investiu capital próprio para avançar com as obras do projeto (figura 18). Segundo o Representante da EO:

Se alguém chegar aqui e entregar a casa pronta por $\mathrm{R} \$ 38.500,00$, não tem 
Figura 18. Organograma do

Fonte: Grupo Habis, 2018.
Editado pelo autor
11 articulaçōes Para aprovação dos Contratos (103 + 17 Casas)

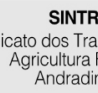

$\downarrow$

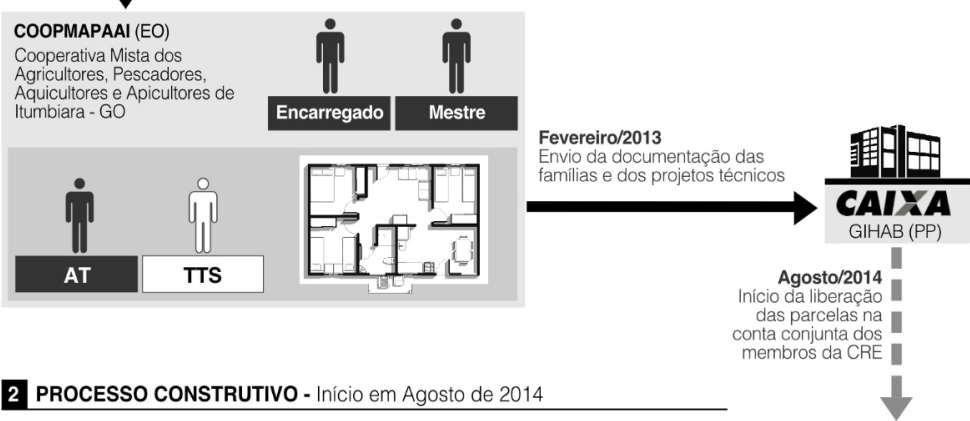

22 Processo ConstruUtivo - Inicicie em Agosto de 2014

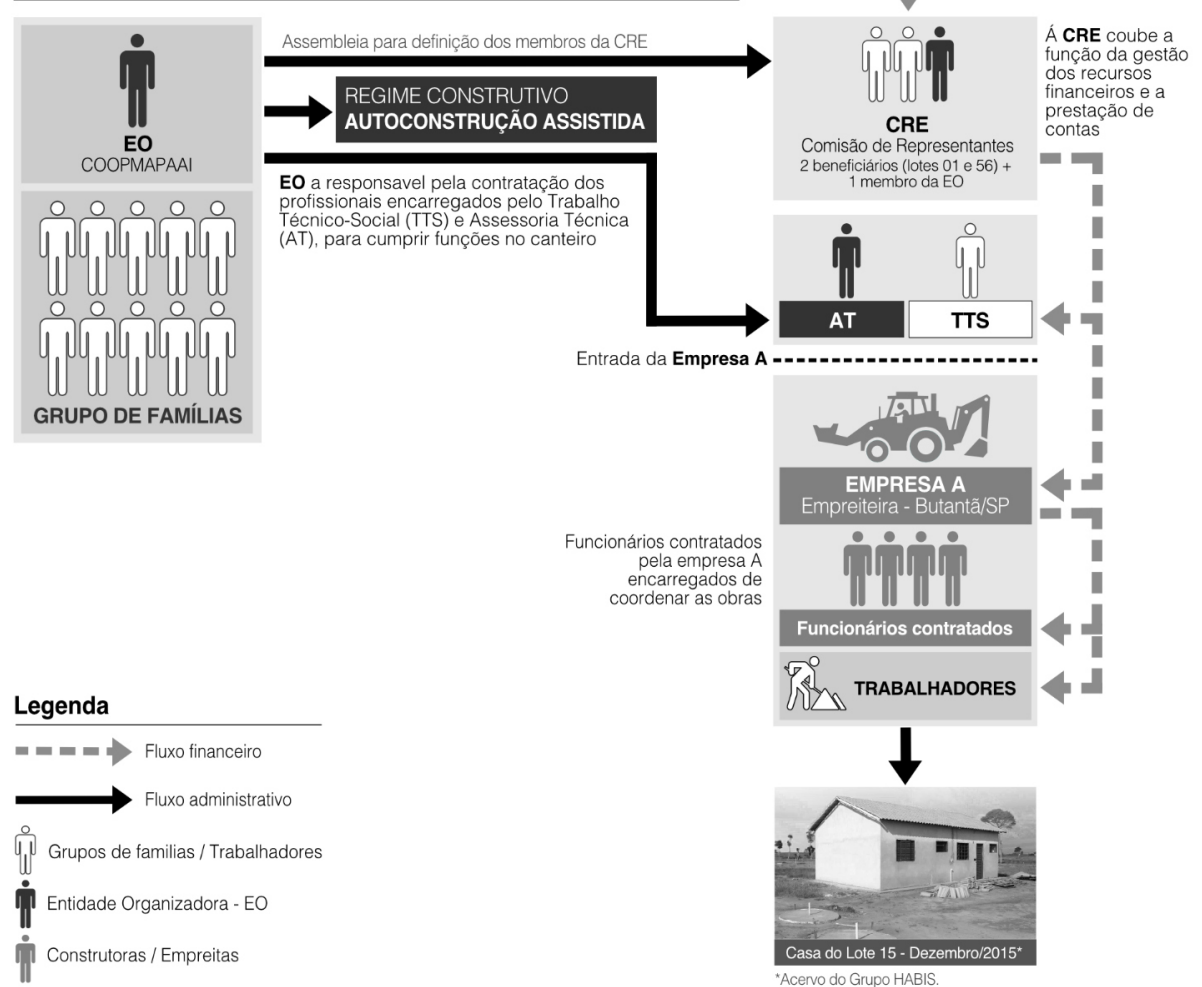

problema. Se a casa atender às especificaçóes exigidas, é a casa que importa. A empresa contratada não deve satisfaçáo às famílias. Sua responsabilidad
é com a CEF e as obras. (Representante da Entidade Organizadora)

Como comprovada na maioria dos casos estudados, a participaçấo das famílias tende a ser mínima, quando muito reduzida, apenas como parte do trabalho altamente desvalorizado. Segundo informaçóes de uma moradora do contrato das 44 casas (Florestan Fernandes), as famílias estavam interessadas em contratar uma empresa pelo motivo de não acreditar muito nas vantagens do mutirāo.

Todo mundo achou que cada um receberia os $\mathrm{R} \$ 38.500,00$ e iria construir sua casa. Mas, a gente caiu do cavalo. O que acontecia, antigamente, era que a pessoa pegava o dhheiro, investía mals um tanto cada um fazia do seu jeito (moradora do assentamento entrevistad).

Segundo a moradora entrevistada, o próprio funcionário da Caixa sugeriu que o MST contratasse uma empreiteira para gerenciar as obras (figura 19). A moradora entrevistada informou que a Empresa B "topou se encarregar pela máo de obra dentro do valor de $\mathrm{R} \$ 8.000,00$ por unidade". O lucro da empresa seria obtido pela redução do valor gasto com os materiais, a estratégia seria negociar os preços diretamente com os fornecedores e também pela reduçáo do valor de mão de obra. Segundo a moradora, o lucro da empresa só seria garantido com a liberaçáo das últimas parcelas do projeto, posto que o dinheiro liberado pela Caixa vinha sendo utilizado na compra dos materiais. Este lucro consta no item referente à remuneração do contrato individual (com cada família) assinado com a Empresa B: "[...] com a obra concluída é dever do CONTRATANTE repassar para o CONTRATADO qualquer quantia de dinheiro que sobre do valor citado acima 


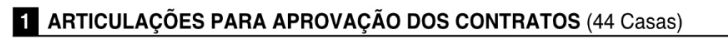

Segundo o morador do lote 135 e membro da CRE, houve uma reuniáo para decidir o regime construtivo. Nesse momento, as famílias decidiram pela autoconstrução assistida, que teria como eixo a mấo de obra do próprio assentamento, sem a necessidade da intervençấo de uma empreiteira, e o apoio de um Assistente Técnico, que seria o responsável pela obra. O morador do lote 135 foi enfático ao dizer que "a casa é nossa! Quem vai morar é a gente! Não precisávamos de empreiteira; a gente dava conta de construir nossas próprias casas". Porém, finalmente, optaram pela empresa, embora algumas famílias náo concordassem com a remuneraçấo da Empresa $\mathrm{B}$ a partir das parcelas finais. Umas das moradoras entrevistadas destacou que seria justamente com este recurso que a empresa conseguiria "ganhar alguma coisa, afinal, não estâo trabalhando de graça". Ela disse ainda que "se não fosse a Empresa B, minha casa não seria construída”.

Finalmente, segundo informaçốes fornecidas pela Assistente Técnica, devido aos inúmeros problemas com a Empresa B, a Empresa A (responsável pelas 120 casas) assumiu as obras das 44 casas, com previsāo de finalizaçấo das obras para o ano 2017.

Do lado dos movimentos sociais, associaçôes, cooperativas, federaçôes

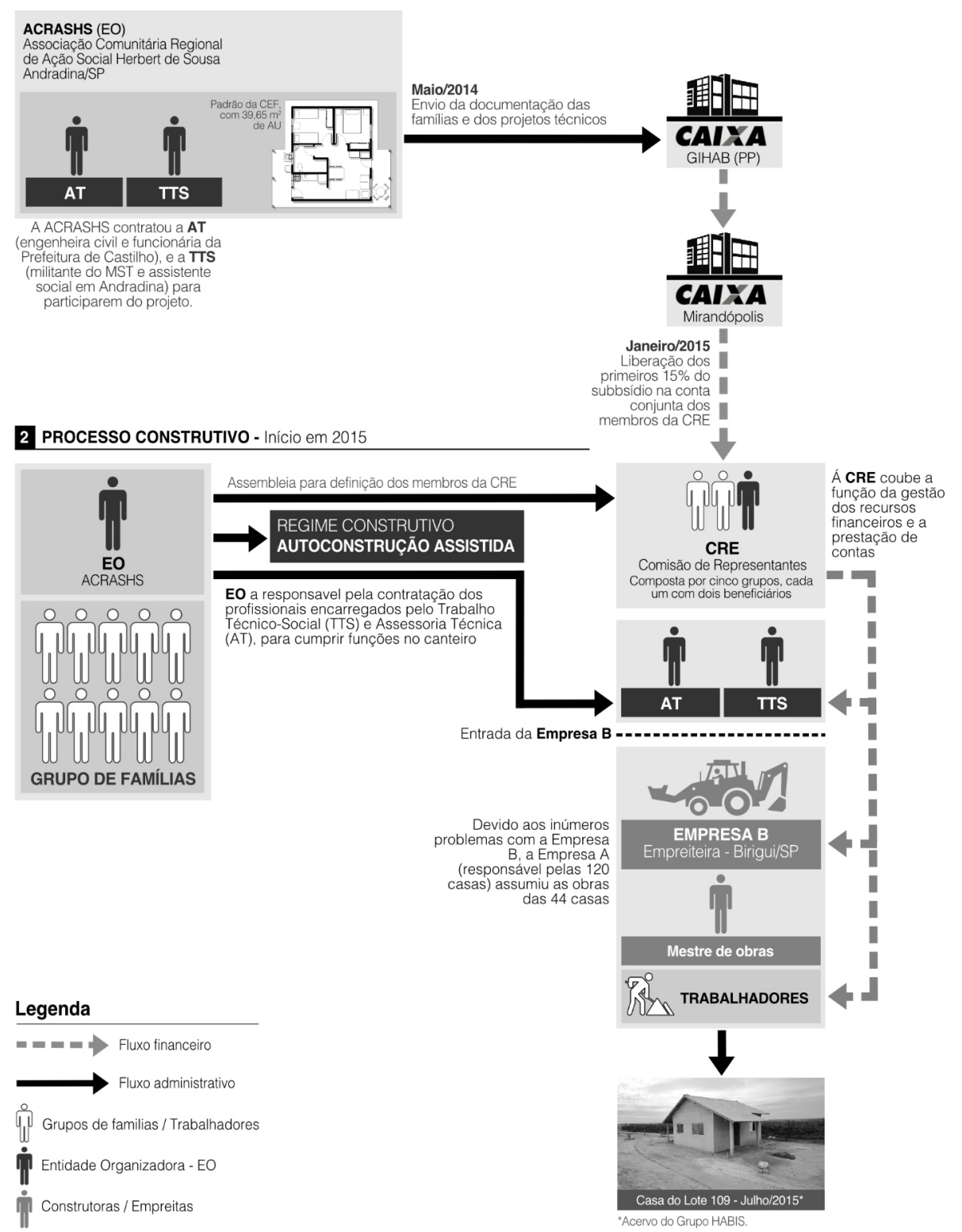


e sindicatos de trabalhadores da agricultura familiar, enfim, as entidades organizadoras destes projetos, foram colocadas pelo PNHR num papel difuso, ou seja, passaram a se responsabilizar - no que concerne apenas às implicaçôes sobre o risco da operação - pela viabilidade dos empreendimentos, fazendo algumas vezes do Estado como promotor habitacional e do empreendedor da construçáo civil. Isso significa que, na condição particular na qual a $\mathrm{EO}$ contrata uma construtora para executar a obra, poderia parecer que esta empresa responderia por todo o processo de construçáo. No entanto, a EO continuaria a ter o compromisso pela finalização do empreendimento e pela entrega das chaves às famílias.

Como já é possível imaginar, as Empresas construtoras (A, B, C, D e E) dos contratos estudados, junto com as Entidades Organizadoras (EOs) detém o "controle técnico da produção". Em primeiro lugar, Jaramillo $(1982,1986)$ define esta categoria

Consiste na capacidade de regular a implementaçáo dos meios de produçáa, do ponto de vista do processo de trabalho: é o caso de funçóes
como a coordenacáo dos diferentes indivíduos e elementos que intervén na produção, a disciplina interna, os ritmos e horários, a programaçāo de
tarefas, etc (JARAMILLO, 1982, p. 176).

Contudo, as Entidades Organizadoras, após serem habilitadas pelo agente financeiro, além das funçôes da interlocuçáo entre os agentes financeiros e as familias e a organizaçáo dos grupos de familias e suas respectivas documentaçōes pessoais, devem definir e realizar as atividades de assistência técnica (AT) em todos os casos. Este profissional contratado pela EO é responsável - em teoria - pela qualificaçáo e supervisão técnica das obras. Estas funçoos de coordenação e fiscalização dos indivíduos, elementos e meios de produçáo que fazem parte do processo produtivo, náo săo exclusivas da $\mathrm{EO}$ - com a responsabilidade contratual dos trabalhos de AT-, uma vez que, nos casos estudados, as empresas construtoras intervêm nas decisōes fundamentais de caráter técnico, assim:

Para o empreendimento das 120 unidades, a Empresa A ficou responsável pela contratação dos funcionários encarregados de coordenar as obras, os pedreiros "fixos" (que recebiam por mês) e os avulsos (para execução de empreitas específicas), também ficando responsável (a empresa) pelo pagamento destes trabalhadores, com o aval da CRE. A empresa fez a distribuiçáo de 07 empreitas nas 120 casas, organizando os trabalhadores em equipes, sendo o mestre responsável pela qualidade do produto final. Segundo a AT "Se a parede ficar torta, eles (a empresa A) mandam consertar e só pagam (os pedreiros) quando tudo estiver certinho". Além disso, um dos funcionários contratados pela empresa A era o responsável por fazer todas as cotaçóes de preços dos materiais e indicar o melhor fornecedor à empresa. Sendo também decisão da empresa a forma como deveria ser armazenado e distribuído para cada canteiro.

Inicialmente, a EO das 44 unidades (Florestan Fernandes) previa que os próprios assentados participassem do processo construtivo, em mutirão. Porém, a Empresa B assumiu a gerência das obras e, em seguida, foi contratado o mestre de obras, que coordenava a cotação, as compras, as entregas e o descarregamento dos materiais no lote de um morador do assentamento. Além de contratar a mão de obra e organizar as empreitas, a Empresa B também interveio na tomada de decisóes técnicas, como a construçáo de uma laje convencional de concreto usinado, mudança que obrigou a reduçáo da área das unidades 
Para o gerenciamento do processo construtivo das 26 casas (Boa Esperança), coube à Empresa C: elaborar os projetos técnicos (arquitetônico, executivo e cronograma físico-financeiro); cotar os materiais, organizar o estoque e acompanhar as entregas; contratar pedreiros; e preencher a Planilha de Levantamento de Serviços (PLS) para cada medição de obras feita pela GIHAB. A Empresa C contava, até setembro de 2015, com aproximadamente 15 funcionários contratados para o gerenciamento da produção de 115 unidades habitacionais na regiáo (tabela 09), 79 localizadas em assentamentos rurais (das quais 26 foram construídas no assentamento Boa Esperança). Inclusive, todos os equipamentos utilizados nas obras foram providenciados pela Empresa C, desde os de grande e médio porte, como caminhóes, betoneiras, geradores e andaimes, até os de porte menor, como pás, colheres de pedreiro, fôrmas metálicas, tábuas, carriolas, martelos, etc.

Por causa da falta de experiência na construçáo civil e pela falta de

Tabela 09. Produçấa Empresa $\mathrm{C}^{29}$

Fonte: Grupo Habis, 2018

\begin{tabular}{cccc}
\hline \multicolumn{4}{c}{ Produção Habitacional da Empresa C (Setembro de 2015) } \\
\hline \multirow{2}{*}{ Estado } & \multicolumn{3}{c}{ Situaçãoo das Unidades Habitacionais } \\
\cline { 2 - 4 } & Finalizadas & Em Andamento & Em Análise \\
\hline São Paulo & 22 & 115 & 78 \\
\hline Espírito Santo & 48 & 182 & 420 \\
\hline
\end{tabular}

pedreiros, os próprios assentados do empreendimento das 27 casas (assentamento Dona Carmem) sugeriram a entrada da empresa D (figura 21). Localizada no perímetro urbano do Mirante do Paranapanema, o pequeno escritório de engenharia e topografia foi indicado pelo secretário de agricultura da prefeitura de Mirante para o

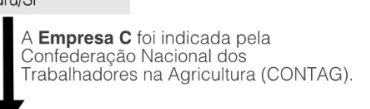

Fonte: Grupo Habis, 2018

Editado pelo autor 
presidente da COOPPAF. Desta forma, a responsabilidade técnica das casas é da Empresa D e, segundo o representante da EO, vale por 8 anos. Coube à Empresa D: elaborar juntamente à EO os projetos técnicos (arquitetônico, executivo e cronograma físico-financeiro); cotar, comprar, armazenar e distribuir os materiais; contratar e pagar aos pedreiros; e acompanhar as obras. No geral, os próprios assentados trabalharam como pedreiros na construçâo de suas casas. Contaram também com a ajuda de outras famílias e de pessoas de fora do assentamento.

No mesmo assentamento, também foi aprovado pela GIHAB de Presidente Prudente um segundo contrato, organizado pela Associaçáo de Produtores Nova Conquista de Mirante do Paranapanema (APNC). Este empreendimento das 10 casas foi gerenciado pela Empresa E, localizada no centro de Teodoro Sampaio, que foi indicada pelo advogado da Entidade Organizadora. Os projetos técnicos foram "desenvolvidos" por um engenheiro contratado pela Empresa E, o qual elaborou três versōes do projeto arquitetônico, dos quais apenas dois modelos (projeto 3 e projeto 5) foram aprovados pela Caixa, cabe destacar que estas duas tipologias contavam com mesmo orçamento. Além disso, de acordo com o engenheiro contratado, os $\mathrm{R} \$ 600,00$ que correspondem à remuneraçâao do Assistente Técnico (por unidade habitacional) foram utilizados para a elaboração dos projetos arquitetônicos, para os orçamentos e para o acompanhamento da obra Além do uso (sob acordo com as 10 famílias) de $2 \%$ do valor total de cada casa $(\mathrm{R} \$ 28.500,00)$ para as despesas com gasolina e cópias de documentos.

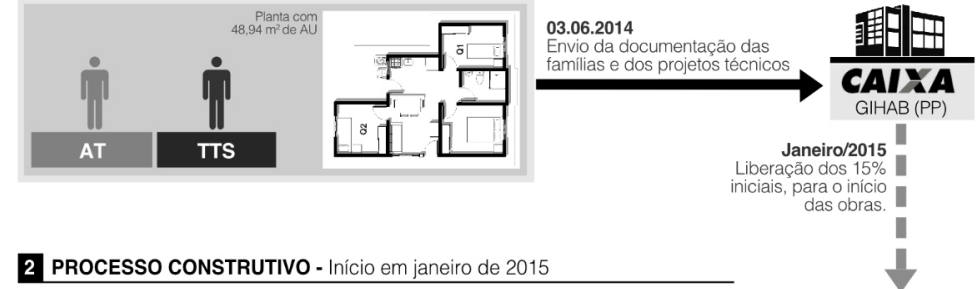

2 PROCESSO CONSTRUTVO - Iníicio em janeiro de 2015

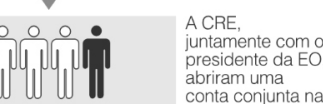

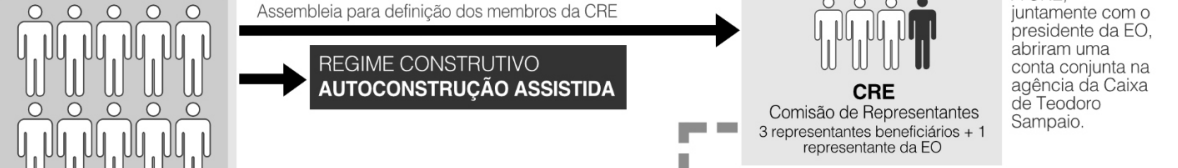
apd 0 GRUPO DE FAMMLIAS
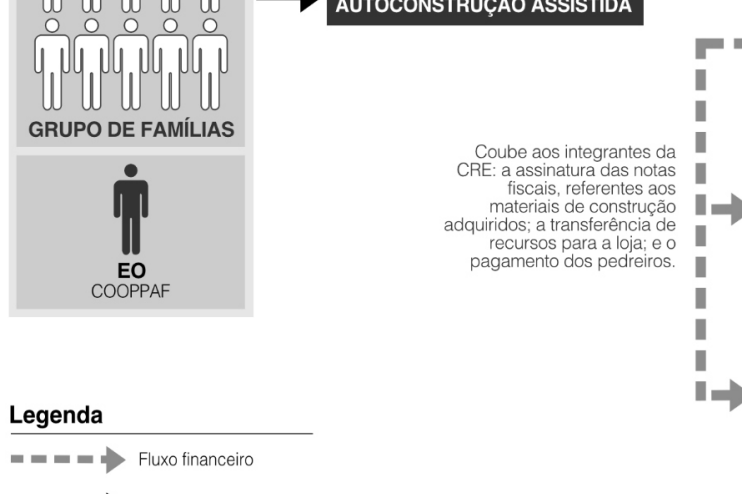

repestantere ca a o

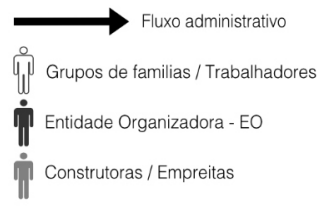


Uma das principais diferenças destes dois agentes, como pautado anteriormente, é a situaçáo da construtora como agente contratado da $\mathrm{EO}$, a qual não tem relaçáo contratual com a Caixa. Assim, o risco final é da Entidade Organizadora e não da construtora. Se a empresa abandonar a obra, a responsabilidade é da $\mathrm{EO}$, e náo da empresa contratada, nem da Caixa. É dessa forma que, juridicamente, o programa entende a participaçáo de uma empresa da construçáo civil dentro do PNHR. Nesta situação, é de grande importância a Assessoria Técnica para fiscalizar a obra e prevenir falhas técnicas e de gestão da empresa.

\section{A subempreitada e a terceirização}

A partir da observaçáo em campo, foi possível identificar duas modalidades de subcontrataçáo. Apoiando-me na descrição de Shimbo (2010, p. 311), de um lado, encontramos aqueles serviços básicos cujos contratos por preços unitários são negociados pessoalmente entre subempreiteiros e o coordenador de obra, são os considerados "empreita". De outro, aqueles que passam por processo de tomada de preços para realizarem um serviço especializado, são os considerados terceirizados. Isto acontece de forma paralela com a contrataçáo direta de trabalhadores, conformando uma equipe própria da empresa e a modalidade de mutiráo, com moradores trabalhando em condiçóes muito diferentes, temas que serão tratados em outros itens. Estas duas categorias - a subempreitada e a terceirizaçâo - serão descritas a seguir.

O primeiro caso eno é a subempreitada mais "simples", ou seja, a destinada a serviços que náo necessariamente requerem um tipo de 
especialização, em que há a contrataçáo de pessoas físicas ou jurídicas para execução de determinadas atividades ligadas à produção, normalmente sob a responsabilidade técnica da empresa principal e subordinada a ela (SHIMBO, 2010, p. 311). No caso do contrato das 120 unidades, o pagamento da máo de obra era feito por empreita. Desta forma, os trabalhadores eram organizados em equipes e seus "contratos" eram estabelecidos junto ao mestre de obras, que assume a responsabilidade pela qualidade do produto final. Ou seja, fica a cargo do próprio mestre decidir sobre a escolha do número e tipo de pedreiros e serventes e sobre a forma e o valor do pagamento que seria feito aos integrantes da sua equipe.

Se a parede ficar torta, eles (a Empresa A) mandam consertar, e só pagam trabalho depende do ritmo da equipe; como ganham por empreita muitas vezes optam por adiantar o serviço nos sábados ou feriados (Coordenador 2 da Empresa A entrevistado)

Desta forma, o ponto mais sensível deste tipo de contratos na modalidade de subempreitada são os prazos de execução do serviço. A puniçáo não necessariamente se traduz em multas financeiras por problemas de qualidade dos serviços, pois, segundo Baravelli (2014, p. 151), é o atraso por causa da não-aprovaçáo que dá sentido ao contrato de "preço fechado". Sendo assim, o preço fixo funciona de imediato como punição ao serviço excessivamente prolongado.

Além dos funcionários contratados pela Empresa A (mestre de obras e coordenador), também foram contratados pedreiros "fixos" e trabalhadores independentes para execuçâo de empreitas especificas, reorganizadas em 07 equipes e distribuídas nas 120 casas. Segundo o coordenador da obra, a maioria desses operários era do próprio assentamento, porém, segundo o coordenador e morador do assentamento, com um valor da MO muito menor do que na cidade. Esta situação de precarização do trabalho e das possíveis "reclamaçōes trabalhistas" aparentemente ficam ao interior da empreita, favorecendo os interesses da empresa contratante.

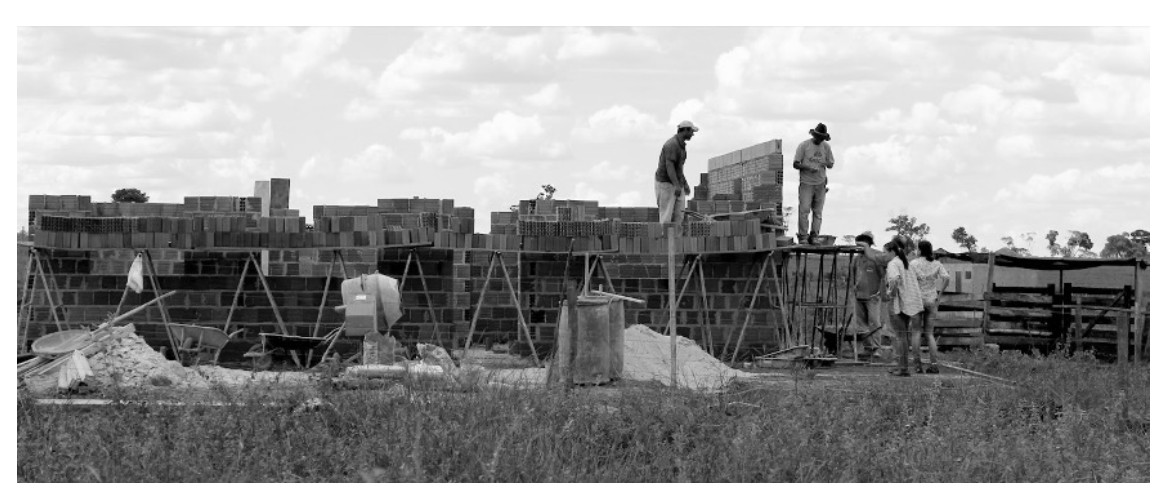

Segundo os representantes da Empresa A, eles esperavam receber R \$ $3.500,00$ de lucro por casa. Para tanto, o orçamento da casa foi revisado, considerando-se náo mais o valor por $\mathrm{m}^{2}$, mas sim os valores das empreitas. Por exemplo, o valor de MO da empreita de reboco e instalaçấo das esquadrias foi de $\mathrm{R} \$ 2.400,00 /$ unidade. Já um dos representantes da CRE informou que alguns pedreiros estavam recebendo $R \$ 1.800,00$ para a mesma empreita. Vemos que a subempreitada favorece o controle dos custos pelo fato de fixar valores para a prestaçáo destes serviços mediante o "jogo" de negociaçăo entre a empresa e a empreita contratada, o que normalmente beneficia quem detém - ou controla os destinos -o capital maior, neste caso a Empresa A. $\mathrm{O}$ pagamento da $\mathrm{MO}$ e dos materiais era feito pela própria Empresa
Figura 23. Empreita de uma cas Trabalhadores e vistoria do coordenador de obra, (Empresa A), a Técnico-Social (TTS) e a

Fonte: Grupo Habis, fevereiro de 2015 
A, com recurso próprio. Quando a GIHAB liberava as parcelas, a EO retinha sua porcentagem dos valores de AT e TTS e transferia o recurso para a Empresa A, para o reembolso dos gastos e extração dos lucros.

Figura 24. Valores pagos pela
Empresa B para as empreitas do Empresa B para as empreitas
contrato das 44 unidades.

Fonte: Elaborado pelo autor

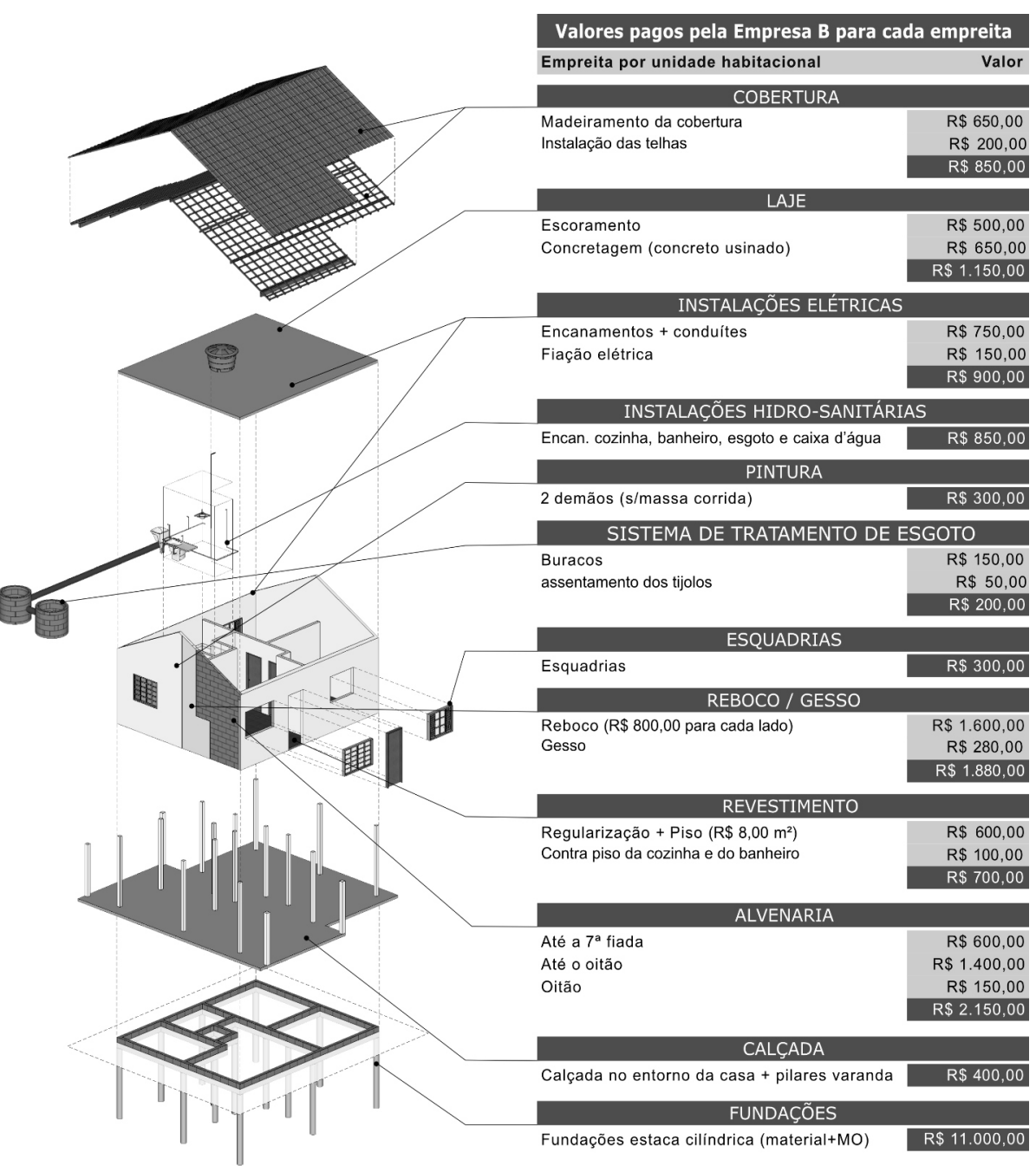

Para o contrato das 44 unidades, a Empresa B havia indicado um mestre de obras e a contrataçấo dos pedreiros (da mesma forma que nas $120 \mathrm{UH}$ ), que também era feita por empreita. Para a AT, o recurso destinado a` $\mathrm{MO}$ funcionava mais como uma ajuda de custo e não concordava com a participação da Empresa B. Segundo ela, era importante que as porcentagens estabelecidas pelo PNHR, referentes à MO de até $35 \%$ do valor total do subsídio (que equivalem a R\$ $592.900,00$ ou $\mathrm{R} \$ 13.475,00$ por unidade) e aos materiais de até $65 \%$ (equivalentes a R \$ $1.101 .100,00$ ou $\mathrm{R} \$ 25.025,00$ por unidade), tivessem sido respeitadas. Uma das etapas para serem revisadas trata da empreita das fundaçóes que, como já descrito anteriormente, a Empresa B fez alteraçáo de radier para 15 estacas cilíndricas de $20 \mathrm{~cm}$ de diâmetro e $3 \mathrm{~m}$ de profundidade e vigas baldrame de $15 \times 20 \mathrm{~cm}$. A empreita, segundo a Empresa B, teve um custo de R 11 mil por unidade (materiais e $\mathrm{MO})^{30}$

Em segundo lugar, encontramos a subempreitada mais complexa ou a chamada terceirizaçáo, que se caracteriza por executar serviços de maio especializaçáo que a subempreitada simples. Comumente, o contratado arca com os riscos e garantias, na medida em que realiza as atividades com total autonomia, substituindo (parcialmente) a empresa principal na realização de determinados serviços. Para executar as estruturas metálicas da cobertura das 120 casas, foi contratada pela Empresa A uma empresa sediada em Araçatuba. Esta conta com uma equipe de quatro trabalhadores fixos, por causa da baixa disponibilidade de MO, sendo três deles são moradores do assentamento Florestan Fernandes.
30. Segundo a tabela SINAP de concreto usinado era de $\mathrm{R} \$$ 335,28. Para esta empreita, o custo do $5.90 \mathrm{~m}^{3}$ de concreto (necessários para as estacas, vig eem um valor R\$ 1.979,00. 


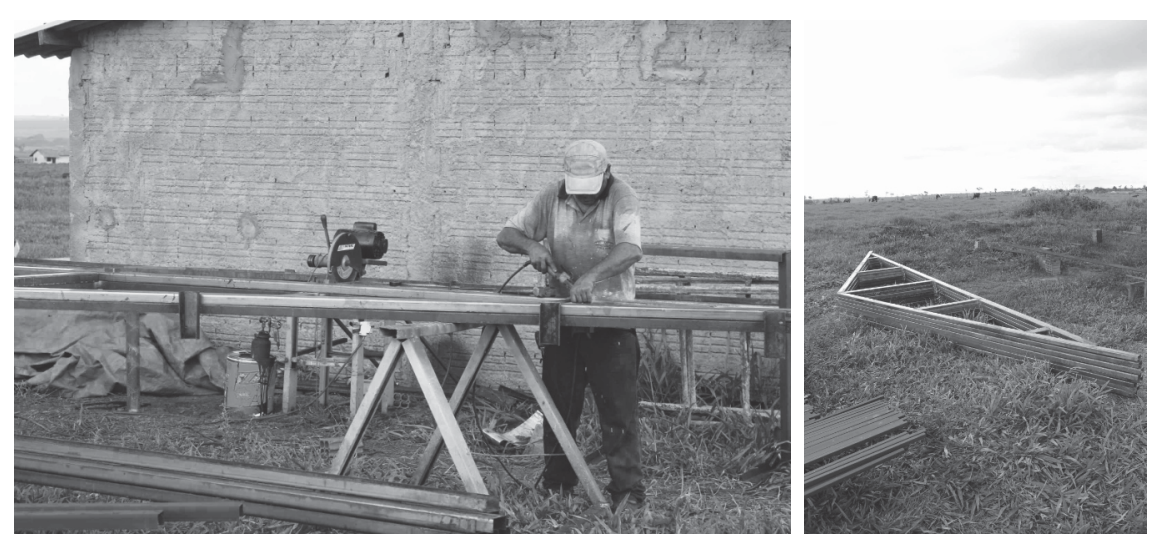

Segundo o representante da empresa terceirizada, o $\mathrm{m}^{2}$ desse componente custou em torno de $\mathrm{R} \$ 33,00$, dos quais $60 \%$ é de máo de obra e $40 \%$ de materiais. A estrutura de uma casa custa $\mathrm{R} \$ 2.400,00$ incluindo fabricação/montagem e instalaçáo na casa. As barras metálicas sáo compradas em Minas Gerais e em Ribeiráo Preto e são pedidas pelo coordenador da Empresa B. Estes pedidos das barras metálicas são feitos para a produção das estruturas de 10 casas e, após a conclusão destas casas, fazem o pedido para outras 10 .

Já no canteiro de obras, são feitas duas casas por dia (produçâo mais montagem) e ele é organizado em duas equipes: três trabalhadores (os moradores do assentamento) fabricam a estrutura no lote 84 (figura 25) e três trabalhadores (o representante da empresa terceirizada e outros dois de Araçatuba) fazem a montagem da estrutura nas casas.

Segundo o representante da empresa terceirizada, a Empresa A fornecera os principais equipamentos de trabalho: máquina de solda, de corte, furadeira, gerador, compressor, óculos de proteçáo, luvas e máscaras (para a produção e instalação). O gasto com o combustível do gerador foi de R\$ 100,00 (por unidade). Este é considerado pela empresa contratante como um aspecto positivo em termos de controle dos custos de obra. De um lado, a subempreitada diminui consideravelmente os "custos de produçáo" relacionados ao material comprado e à força de trabalho, transferidos para a empresa contratada. De outro, como já vimos, fica sob a responsabilidade da empresa terceirizada os serviços de manutençáa de equipamentos, como máquinas, andaimes, instalaçóes de apoio e, inclusive, custos de alimentaçáo e alojamento da mấo-de-obra.

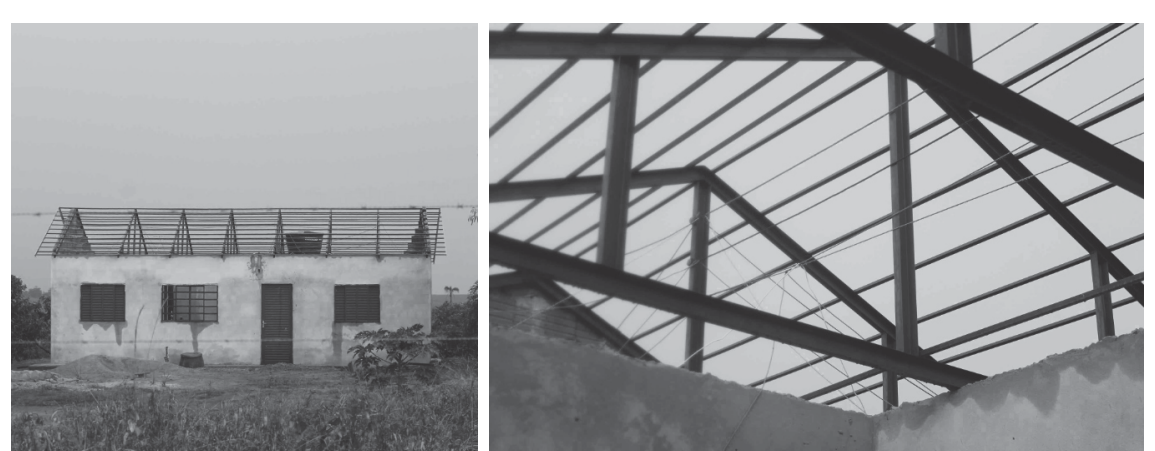

Figura 26. Estrutura de cobertura do contrato das 120 casas (Florestan Fernandes)

Fonte: Grupo Habis, fevereiro

Uma das principais características da terceirizaçáo, a diferença da subempreitada mais simples, está no cotidiano do canteiro de obras, pois a atuação do serviço terceirizado é mais pontual, com um prazo menor de execução e por causa da configuração dos níveis hierárquicos no canteiro de obras, quase náo existe um contato entre os trabalhadores terceirizados e as outras equipes. Ou seja, enquanto os trabalhadores das equipes próprias ou inclusive os subempreitados, que realizam serviços básicos, permanecem um tempo maior na obra e estáo sujeitos à maior intervenção do engenheiro e do mestre. Os 
trabalhadores das empresas terceirizadas normalmente não são subordinados ao mestre ou ao coordenador de obras.

Segundo Baravelli (2014), na lógica da terceirizaçáo, a construtora contratante depende da rapidez da produçáo para competir na concorrência de mercado, procurando a valorizaçáo do capital investido a partir do controle do tempo em canteiro. O sentido material da subempreitada de serviços especializados é diminuir aproximando os momentos da "fórmula geral do capital" em que o capital é investido na produçáo de uma mercadoria (Dinheiro-Mercadoria) e outro posterior, enc que a mercadoria é vendida e se tora)

Porém, nos casos estudados, em que as moradias não se tornarão numa mercadoria, a extraçăo de maior valor consiste na relaçăo entre estas pequenas empresas, ou seja, enquanto a contratada comercializa e controla a força de trabalho, com altos custos, a empresa contratante controla as condiçôes financeiras, definindo a produtividade desta força de trabalho em condiçôes confortáveis, sem maiores riscos e reduzindo custos de produção 

Trabalho - entendida como a açáo do homem dirigida a fins determinados. É a atividade material orientada por um projeto. O homem modifica a natureza por trabalho e modifica-se a si mesmo. Este componente se refere à divisão do trabalho em seus diversos níveis, as relaçôes entre os trabalhadores no processo de produção e à formaçáo e "transmissão" do conhecimento e das habilidades;

Materiais - envolve basicamente o estudo dos materiais a serem transformados, desde as matérias primas que estão no início de uma cadeia até os componentes derivados destes materiais naturais, todos eles usados na fabricaçáo dos mais variados objetos de uso diário, doméstico ou industrial;

Meios de trabalho — sáo aqueles pelos quais o homem exerce sua açấo sobre os materiais. São um conjunto de coisas que o trabalhador coloca entre si mesmo e o objeto de seu trabalho. Inclui-se o conhecimento dos instrumentos, utensílios, ferramentas, máquinas e a utilização da energia em suas diversas formas

Praxiologia —reúne um conjunto de disciplinas e técnicas que alimentam e dáo apoio aos outros componentes da tecnologia. A lógica da atividade racional orientada para a ação: (1) preparaçáo através de uma reflexão prévia sobre a açẫo; (2) economia e controle dos atos; (3) instrumentaçẫo e utilização dos meios materiais; e (4) organizaçáo, interação e coordenaçáo dos diversos agentes.

Estes componentes da tecnologia são representados pelo Gama (1986, p. 195) através de um tetraedro regular com quatro faces triangulares. Esta representação geométrica é interessante para nosso estudo, pois, além de caracterizar os componentes que, de fato, auxiliaram na sistematizaçáo das informaçôes de cada contrato, permitiu compreender que estes elementos não estão isolados, visto que cada um destes quatro componentes se inter-relacionam entre si (figura 27).

Desta forma, e para conseguir uma maior aproximação à realidade, o arranjo desta terceira parte partiu de três grandes questôes que náo pretendem se encaixar necessariamente nestes triângulos, e sim aproveitar os diferentes matizes, produto da correlação destes componentes. Em primeiro lugar, são descritas as particularidades físicas do lugar do canteiro de obras, que se diferenciam dos que encontramos nas cidades, pois se caracterizam pela descentralizaçáo de pequenos canteiros dispersos e pela ausência de infraestrutura no assentamento (redes de água e energia). Estas condiçōes particulares fazem com que a gestáo e a organização dos elementos em canteiro (trabalho, materiais e meios de trabalho) se tornem ainda mais complexos. Outra questáo se refere à presença de práticas construtivas ligadas à manufatura que aparentemente persistiam ante alguns processos de produçáo mais racionalizados, situaçáo que parte da confluência entre o "saber-fazer" e as mudanças introduzidas por processos, materiais, componentes e sistemas construtivos e a posição do campesinato (como força de trabalho) diante destas condiçôes, ou seja, a preservaçáo da sua autonomia ou a submissão do trabalho camponês ao capital. 


\section{8. limitações que influenciaram o processo}

\section{construtivo}

Os três assentamentos rurais analisados, apesar de terem sido criados muito depois dos intensos conflitos fundiários do oeste paulista, a configuração da sua dimensão espacial é resultante destes processos. Desta forma, somadas à territorializaçáo da reforma agrária, as características físicas destes assentamentos se configuram em uma das principais limitaçóes que influenciaram o processo construtivo dos empreendimentos estudados, uma vez que o PNHR náo prevê, em suas normativas, nenhum aporte financeiro (ou qualquer outra modalidade adicional de recursos) destinado para o aluguel de equipamentos de obra, como betoneiras ou geradores, necessários para a dinâmica de canteiros de obra dispersos de baixa escala e distantes das áreas urbanas. Esta situaçấo se torna ainda mais complexa pela ausência de infraestrutura adequada nos assentamentos, como rede de água e energia na etapa de construçăo, e as más condiçóes das estradas internas que dáo acesso a estas comunidades rurais, situaçáo que eleva consideravelmente os custos de transportes de materiais, estocagem e deslocamento dos construtores, tornando o processo construtivo pouco eficiente, dinâmico e com baixos índices de produtividade. epressiva de cana-de-zyct municipio de Mirandopolis que
de acordo com a Secretaria de Regional, conta com a maio
Rejamento e eselvimento produçāo bovina da regiâa de Araçatuba, com 73.008 cabeças

dados sáo relevantes se se Florestan Fernandes se encontra dizado em uma antiga fazend ocalizado na área de influência da Usina de cana Raízen/Mundial.

\subsection{O canteiro de obras disperso}

$\mathrm{O}$ assentamento Florestan Fernandes está localizado na Regiáo Administrativa (RA) de Araçatuba, a aproximadamente $28 \mathrm{Km}$ do município de Mirandópolis (figura 28). A regiâo se caracteriza pela economia baseada na produçáo agropecuária integrada à atividade industrial ${ }^{31}$. Além disso, é reconhecida pela forte concentraçáo de assentamentos rurais, e pela atuação de vários movimentos sociais. Em
2003, no início da expansão da cana de acúcar, a regiáo contava com doze assentamentos ${ }^{32}$. Entre 2003 e 2010 foram criadas outras 30 implantaçôes, gerando um acréscimo considerável de área parcelada (crescimento de 43\%) e de famílias beneficiadas (2.699 famílias). Apesar desse aumento ser maior do que em qualquer outra regiáo do estado, ainda é evidente a força que a iniciativa pública disponibiliza ao agronegócio canavieiro ${ }^{33}$ (CARAFFA, 2014).

O assentamento Florestan Fernandes surgiu como acampamento em meados de 2001, envolvendo de 150 a 180 famílias na antiga Fazenda Retiro, latifúndio antes destinado a pastagens para a criação de gado. As organizaçôes presentes no processo de ocupaçáo da área eram a Confederação Nacional dos Trabalhadores na Agricultura (CONTAG), o Sindicato dos Trabalhadores na Agricultura Familiar (SINTRAF) e, posteriormente, o acampamento do MST. Este finalizou com sua regularizaçăo, feita pelo INCRA, no dia 25 de abril de 2013. 0. Estes assentamentos foram pressóes exercidas pelos movimentos sociais, mas sem um projeto claro e consistente de toforma agrária. $O$ primeiro deles 1981 (HESPANHOL et al, 2003).

33. Já na metade da década de 1990 , pelos grandes estabelecimentos agropecuários na regiáo de Andradina é bastante superior à média do estado de SP. A área média Andradina (125,7 hectares) era muito superior à registrada para o estado de SP 779,6 hectares

Figura 28. Localizaçáo do
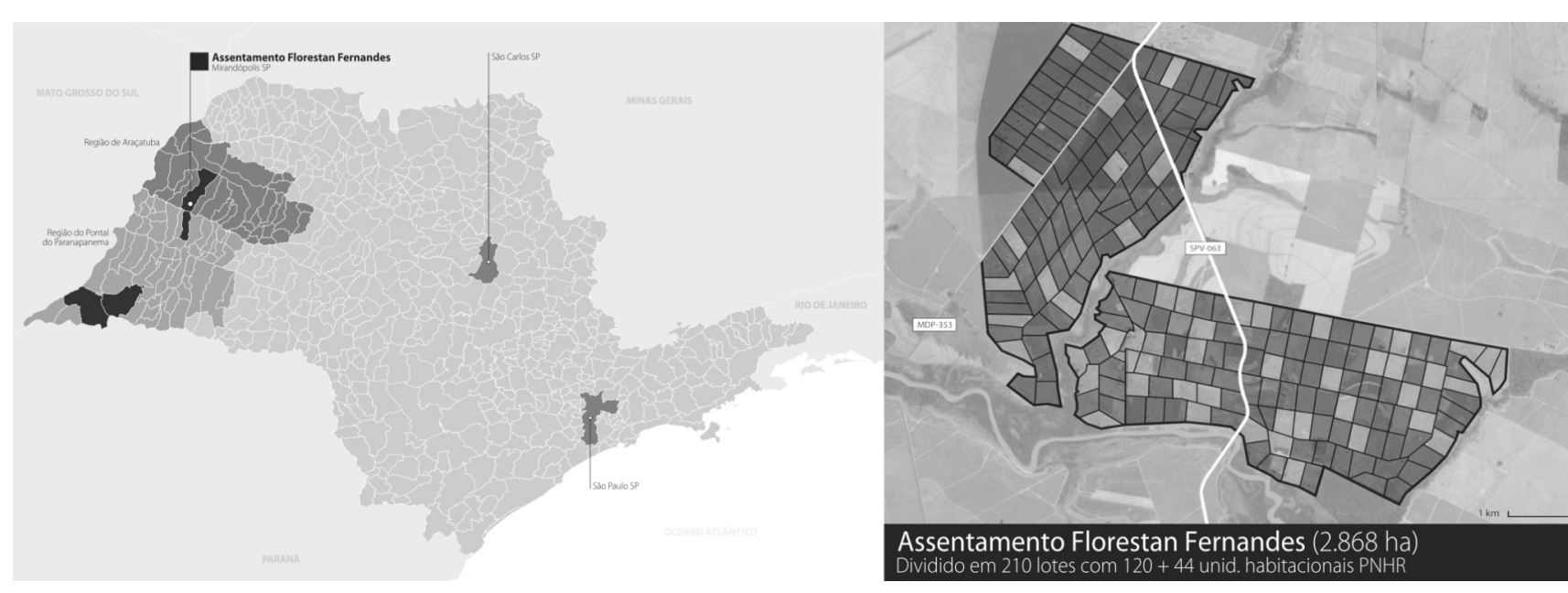

Fonte: Elaboraçāo do autor 
O assentamento tem um tamanho de 2.868 hectares e está dividido em 210 lotes de aproximadamente 10 hectares, o que permite deduzir uma distância considerável entre os canteiros de obra. A ocupação de cada lote do assentamento foi feita por sorteio, sendo inicialmente 103 lotes. Espacialmente, a antiga fazenda estava dividida em glebas, comumente formadas pelo tipo de solo ou características físicas do lugar, configuraçấo que foi mantida para a concepçâo da proposta do parcelamento em abril de 2013. Esta proposta pretendia desenvolver, além dos lotes familiares para exploraçáo agrícola, 03 áreas comunitárias (A, B e área construída), construídas parcialmente; 01 espaço para esporte e lazer (não realizado) e 13 parcelas de apoio comercial (não realizadas) (figura 29). O assentamento conta com uma sede bem estruturada com casas e galpóes (benfeitorias da antiga fazenda). Estes espaços foram aproveitados pelos assentados para programas de formaçáo e algumas atividades do processo construtivo das moradias.
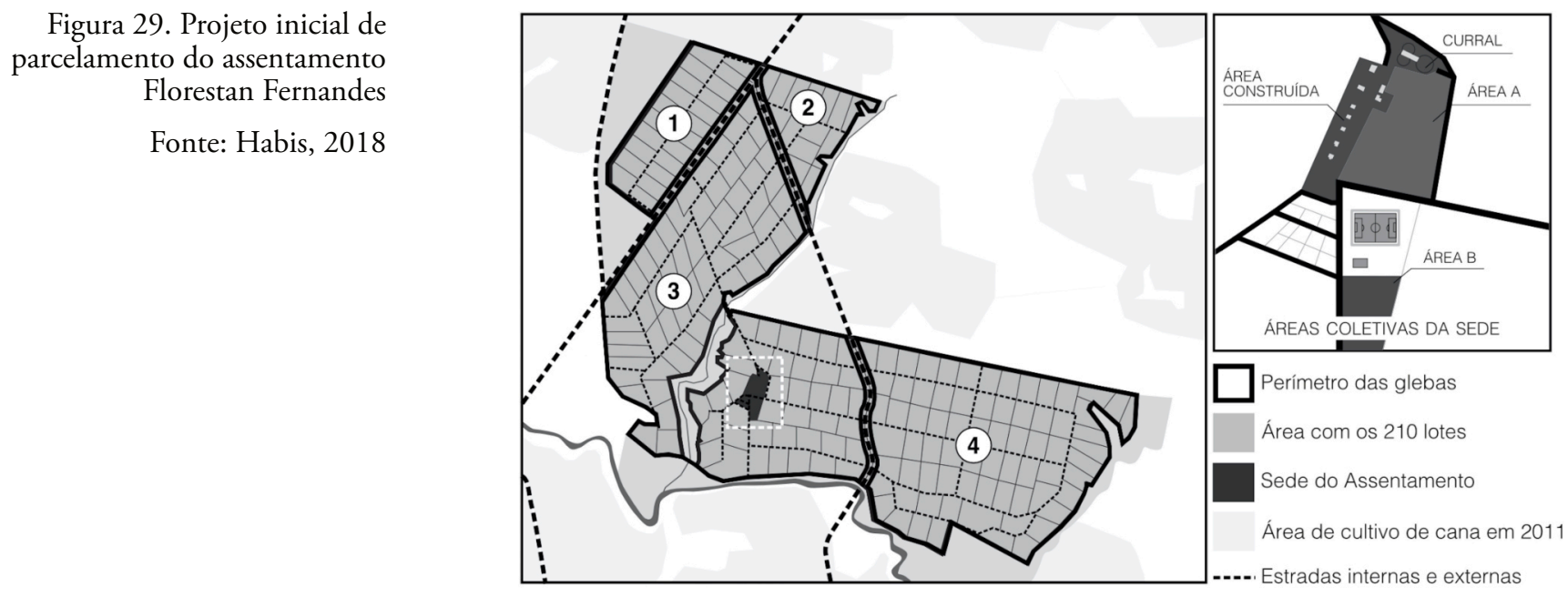

Vale a pena destacar que o assentamento Florestan Fernandes está dividido em dois núcleos ou contratos PNHR, sendo um de 120 casas e o outro de 44 casas, que serão estudados separadamente, pois, apesar de compartir o mesmo território, foram desenvolvidos de formas diferentes e se distinguem, principalmente, pelos agentes e sua relação, já que o processo construtivo de cada contrato foi gerenciado por empreiteiras distintas, por projeto e processos construtivos variados, pela aplicação dos recursos e pela gestáo, pelo planejamento e pela organização no canteiro de obras.

Quanto à logística do canteiro de obras no empreendimento das 120 casas, foi decidido montar a estrutura das coberturas no lote 84 (figura 30), peças que depois foram transportadas para os demais lotes com o auxílio do trator de um dos beneficiários (assentado do lote 48). Já em dezembro de 2015, o descarregamento das peças metálicas, a montagem e o armazenamento das treliças prontas estavam acontecendo na sede do assentamento.

Além disso, todo o material era entregue em um só local do assentamento, que poderia variar de acordo com a localizaçáo das empreitas das casas que estavam em andamento. Deste local, os materiais eram distribuídos por um trator com uma carretinha - serviço que, inicialmente, era prestado por um morador do assentamento. $\mathrm{O}$ aluguel do trator foi pago pela Empresa A. 

Centeiros das 120 casas (Florestan
Fernandes) Fonte: Elaboraçấo do auto

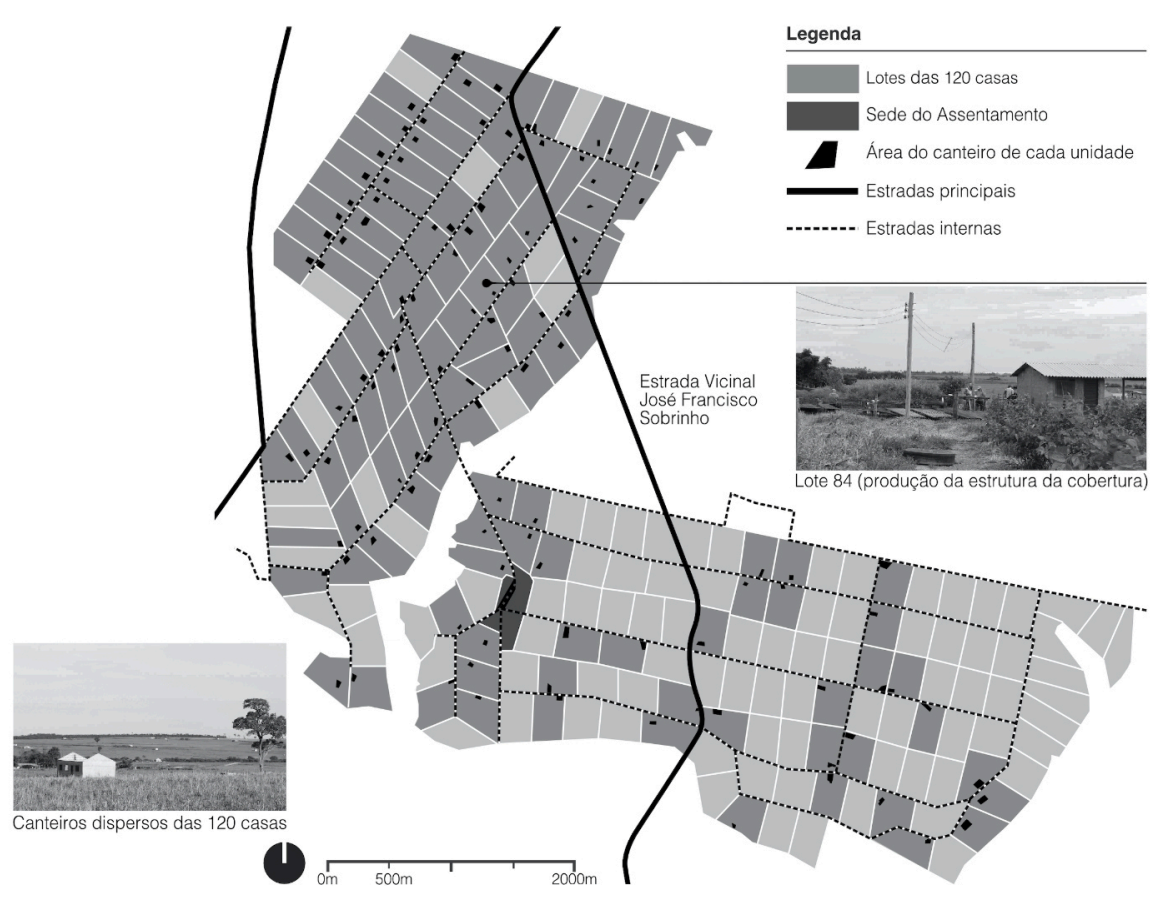

Já sobre a logística nos canteiros de obra do empreendimento das 44 casas, o combinado com os fornecedores foi de que a distribuiçáo dos materiais seria feita diretamente em cada lote. Segundo a moradora responsável pelo orçamento dos materiais, "a gente colocou na ponta do lápis e viu que ficaria mais caro contratar alguém de dentro do assentamento para fazer a distribuição dos materiais". Porém, em alguns casos em que as entregas dos materiais, lote a lote, náo compensavam financeiramente, o transporte era feito com trator alugado. Em dezembro de 2015, o representante da Empresa B disse gastar R \$ 5 mil por mês só com o transporte de materiais entre os lotes.

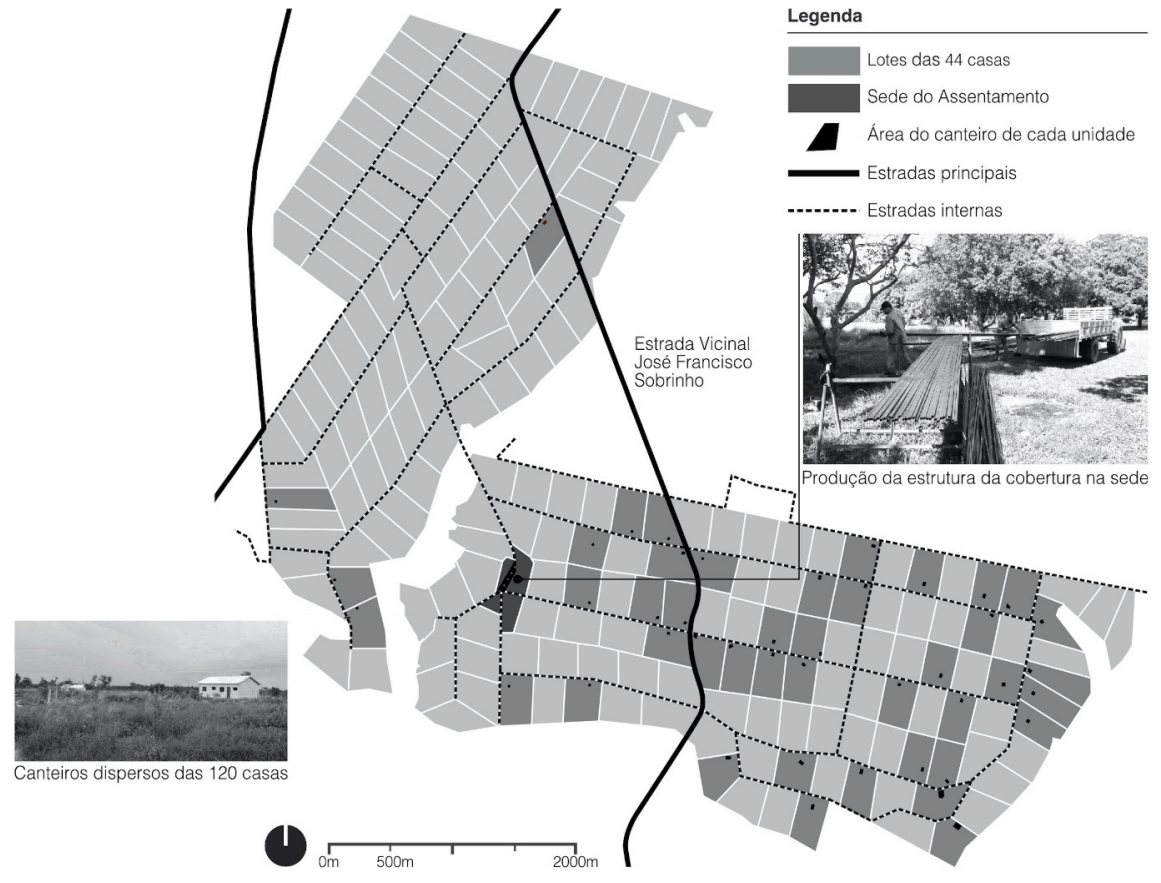

O assentamento Boa Esperança encontra-se localizado na Regiáo Administrativa (RA) de Presidente Prudente, a aproximadamente 10 $\mathrm{km}$ do município de Pacaembu/SP. A economia regional é baseada na produçấo agropecuária, com expressiva participação da cana-de-açúcar e pecuária bovina ${ }^{34}$

A região do Pontal do Paranapanema é considerada a área de maior concentração dos conflitos fundiários no estado de São Paulo. Só após muita pressão em áreas devolutas estaduais e a partir de açoes judiciais reivindicatórias que têm sido implantados os múltiplos projetos de assentamentos existentes na regiāo. A questáo fundiária no Pontal do
Figura 31. Localizaçáo dos Fernandes)

Fonte: Elaboraçăo do autor

34. O município de Pacaembu, de a cordo com a Secretaria de Regional, conta com uma área toto ocupada de cana-de-açúcar bovina de 8.148 cabeças de gado, entre 2007 e 2008. 
Paranapanema tem suas origens a partir da segunda metade do século XIX, quando as terras começaram a ser griladas, caracterizando-se, assim, como um dos maiores processos de grilagem de terras devolutas Figura 32. Localização do da história do Brasil.

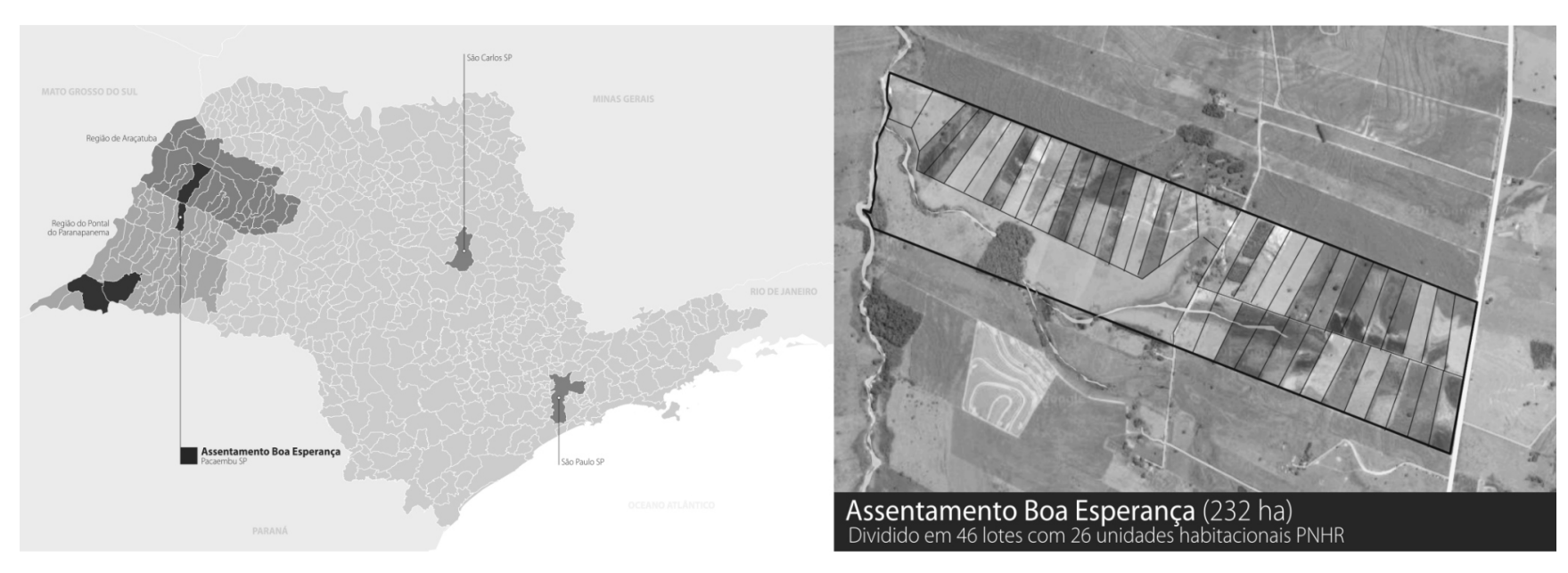

Fonte: Elaboraçáo do autor

Em um período histórico brasileiro, caracterizado pelo êxodo rural, aumento das desigualdades sociais, desemprego no campo e na cidade, entre outros, o número de famílias sem-terra em aumento encontrou como única alternativa retornar para o campo, por ser um contexto amplamente conhecido e com maiores chances de sobrevivência e desenvolvimento do que nas cidades. Desta forma, movimentos como o MST chegaram à regiáo no início da década de 1990, atraídos pelo latifúndio improdutivo e as enormes quantidades de terras griladas.

O assentamento Boa Esperança surgiu com a compra da propriedade por meio do Programa de Crédito Fundiário (PNCF), do Ministério do Desenvolvimento Agrário (MDA), lançado em 2003, durante o primeiro governo Lula. O processo se iniciou em 2002 e, cinco anos depois foi liberado para cada família $\mathrm{R} \$ 40.000,00$ do Crédito por meio da modalidade "Consolidaçáo da Agricultura Familiar". A fazenda de 96 alqueires antes era utilizada para pastagem de criaçáo de gado, segundo os representantes da FETAESP, e foi colocada à disposição para venda por um valor de $\mathrm{R} \$ 1.728 .000,00(\mathrm{R} \$ 7.438,02$ por hectare). Após a compra do terreno em 2007, foi transformado em assentamento e as 46 famílias foram alocadas nos lotes por sorteio.

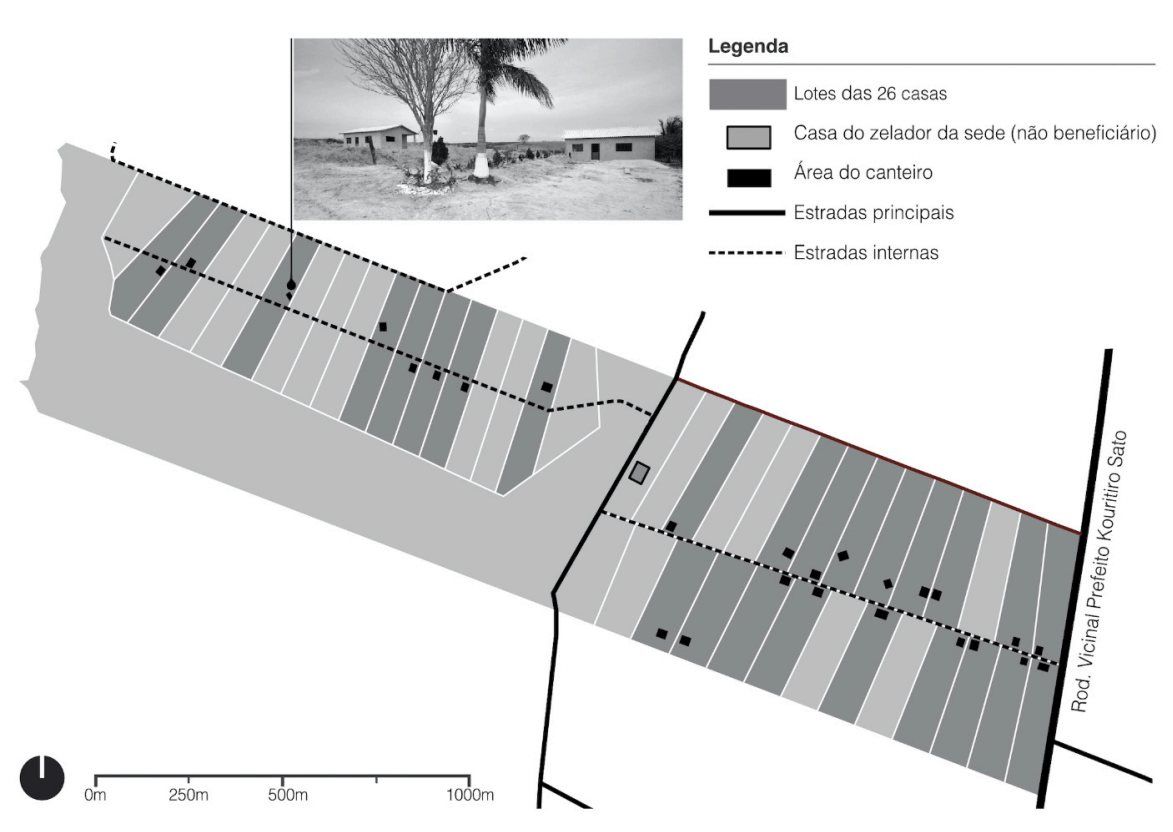

Em primeiro lugar, fomos informados por um dos funcionarios da $\mathrm{EO}$ do assentamento Boa Esperança sobre a formação de pequenos núcleos de moradia ${ }^{35}$, decorrentes da proximidade entre as unidades habitacionais. Tanto o local de implantação das casas quanto sua orientação foram decididos pelas próprias famílias. No decorrer das
Figura 33. Localizaçáo dos canteiros das 26 Fonte: Elaboraçăo do autor 35. Proposta apresentada pela
Confederaçáo das Cooperativas Reforma Agrária do Brasil as moradias dos assentados,
localizadas em seus respectivos lotes, estivessem consideravelmente próximas umas das outras. Para
tanto a formaçáo dos núleos de moradia, além de considerar as infraestruturas e áreas coletivas, deveria propor um novo traçado principalmente nos municííios co
módulos fiscais abaixo de 25 ha. 
A organizaçáo do processo construtivo em empreitas, associada à proximidade dos lotes, foi a estratégia encontrada pela Empresa C. Assim, foi possível evitar gastos com aluguel de equipamentos adicionais e também facilitar a alocação dos equipamentos alugados (bem como o fornecimento de água e energia) entre os canteiros.

A centralizaçáo do estoque e a proximidade entre os canteiros otimizaram as entregas de lote a lote. A estratégia de centralizar os equipamentos e o estoque de materiais em um único local, a proximidade entre os canteiros e a produção de diversos tipos de componentes em série (controlando seu estoque e suas saídas para a obra) permitiu otimizar a construçâo das unidades.

36. Cabe destacar que, de acordo com a Secretaria de Planejamento
e Desenvolvimento Regional, município de Mirante do Paranapanema foi uns do responsáveis por $74 \%$ da area
llivada de mandioca na regiä entre 2007 e 2008, aspecto que que este produto é o mais que este produto é o mas
cultivado pelos moradores do Assentamento Dona Carmem.

O assentamento Dona Carmem se encontra localizado na Regiáo Administrativa (RA) de Presidente Prudente, a aproximadamente 43 $\mathrm{km}$ do município de Mirante do Paranapanema/SP e a $2,5 \mathrm{~km}$ do município de Teodoro Sampaio/SP. A economia regional é baseada na produçấo agropecuária, com expressiva participação da cana-de-açúcar e pecuária bovina ${ }^{36}$

O Assentamento localiza-se na regiáo polo do conflito agrário no estado de Sáo Paulo, próximo a outros assentamentos como o Che Guevara, o Paulo Freire e o Antônio Conselheiro, beneficiando-se da boa infraestrutura (saúde, escolas, dentre outras).
Figura 34. Localizaçáo do
assentamento Dona Carmem
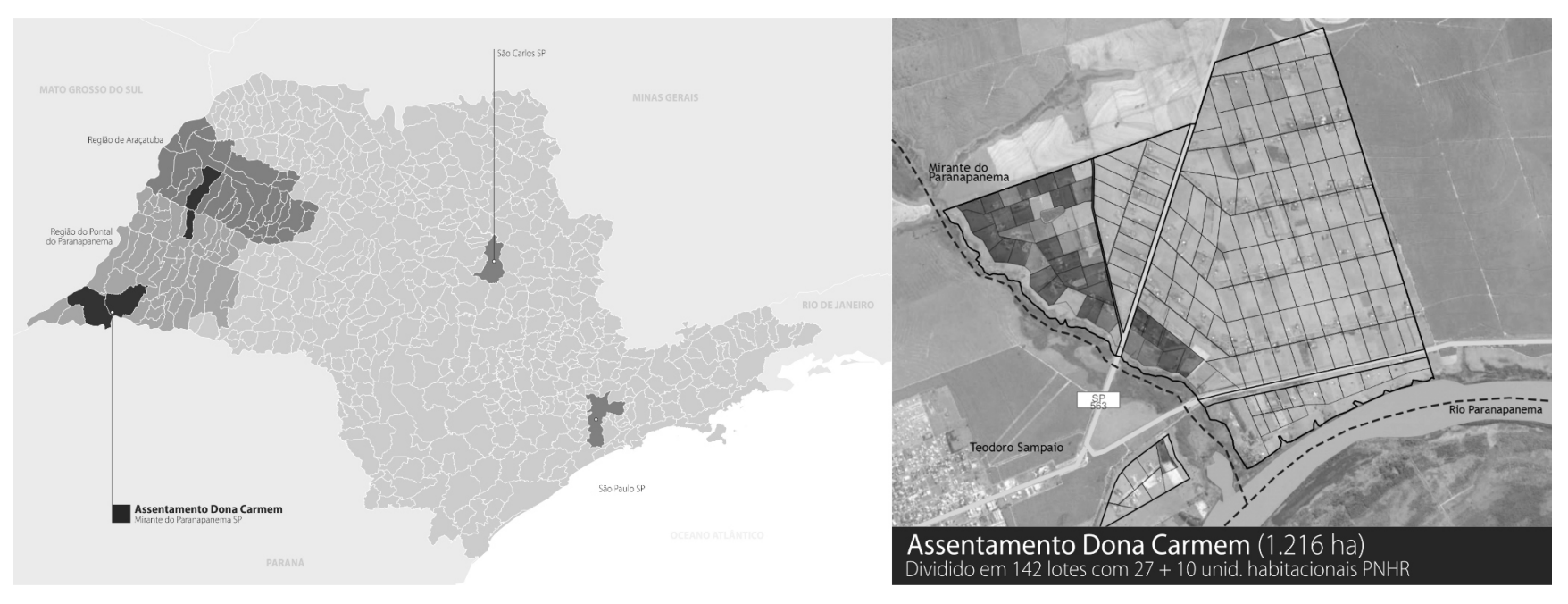

Fonte: Elaboraçáo do auto

Este assentamento, antiga Fazenda São Sebastiáo ${ }^{37}$, surgiu como acampamento há 11 anos, com data de regularizaçáo em setembro de 2008. No âmbito da segunda versão do PNRA, foi criado em uma área de 1.216 hectares e dividido inicialmente em 142 lotes inicialmente de aproximadamente 06 hectares cada, mas, atualmente, possui 185 lotes ao todo.

No caso dos contratos do G1, apesar de o PNHR náo considerar as despesas com aluguel de equipamentos para os canteiros dispersos e tấo pouco remunerar o trabalho das Entidades Organizadoras, o representante da $\mathrm{EO}$ informou que preferiu náo cobrar nenhuma porcentagem do recurso do programa - o que poderia ajudar com os gastos da COOPPAF referentes à operacionalizaçáo do contrato.
37. O antigo proprietério da
lazenda manifesta interesse de enda ao INCRA que, posteriormente, pagou R\$
6.890673818 d des $6.890 .673,81$ de desapropriaçá
com custo de R\$ 48.879,03 com custo de RS
lote $(1411$ lotes iniciais ou
SS $5.666,09$ por hectare. 


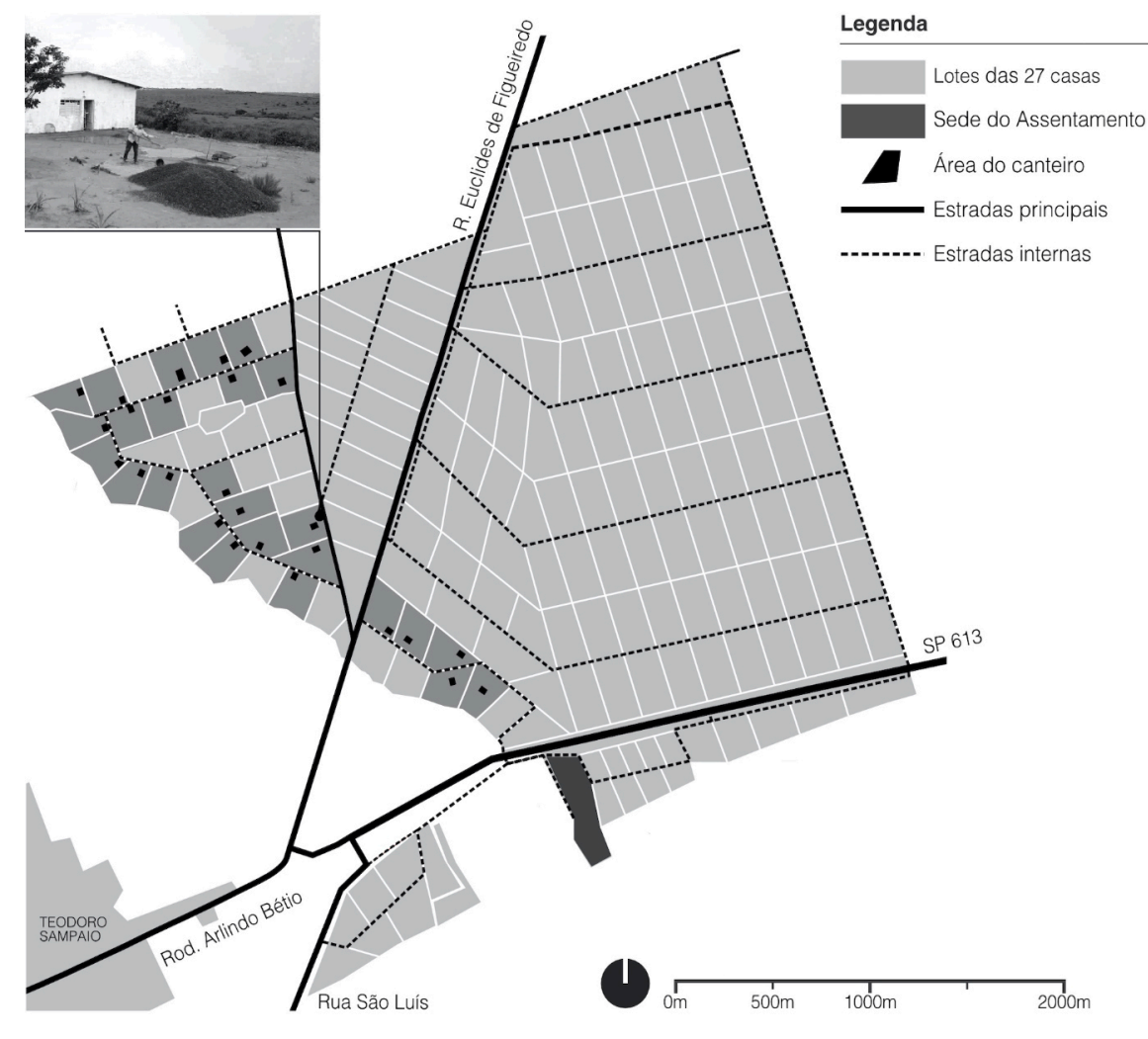

Após cotaçōes de materiais realizadas em Mirante do Paranapanema e em Teodoro Sampaio, a Empresa D fechou um acordo com uma loja de materiais de construçáo de Teodoro Sampaio, por ser considerada mais próxima ao assentamento. Segundo o proprietário da empresa, os preços dos materiais oferecidos por esta loja eram 50\% menores em relação aos que foram orçados em Mirante. Segundo os profissionais da Empresa D, a compra de materiais em apenas um fornecedor também permitiu um acordo de pagamento viável — uma vez que poderiam ocorrer possíveis atrasos na liberação de recursos pela GIHAB.

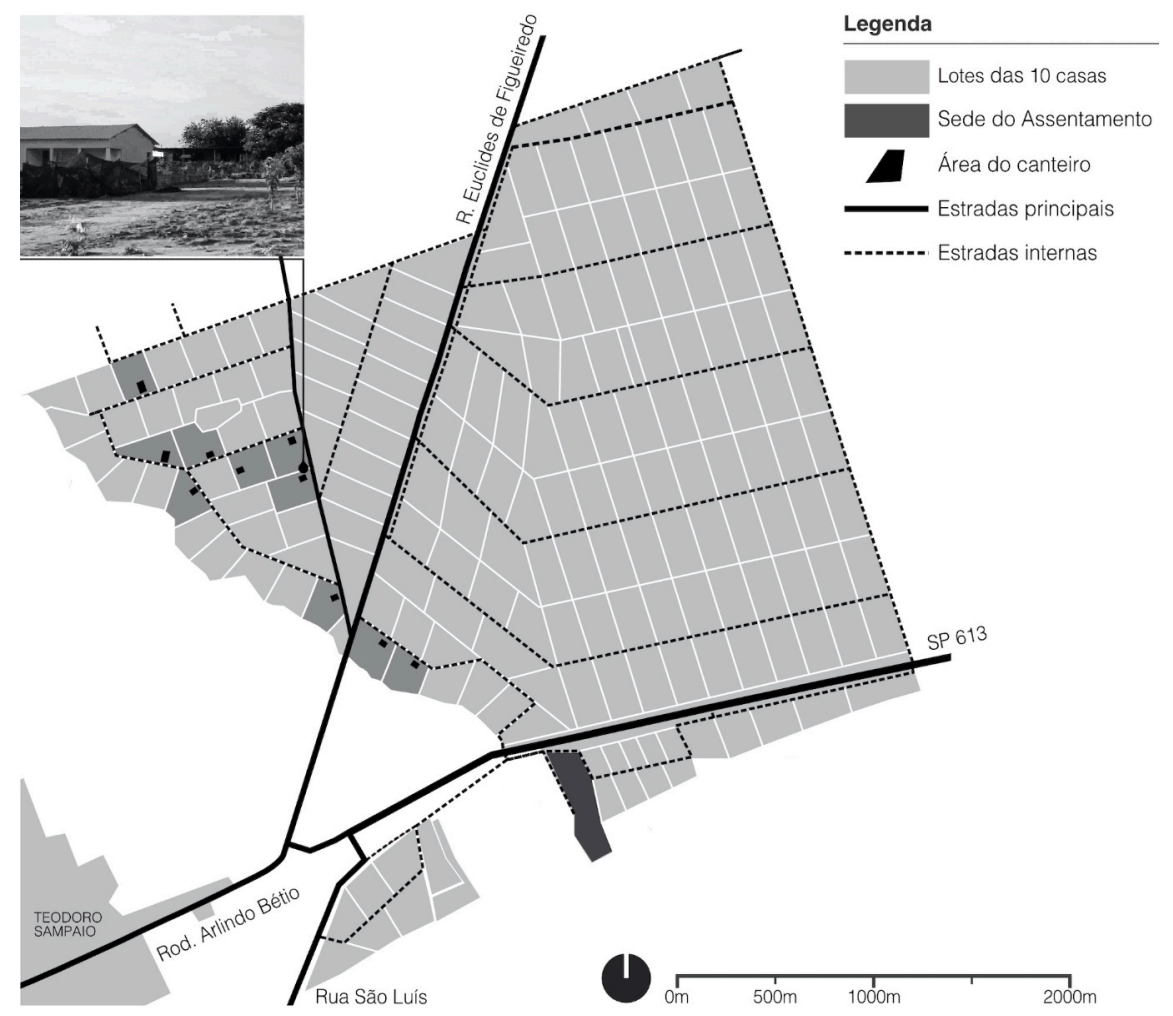

Figura 36. Localizaçáo dos canteiros
Carmem

Fonte: Elaboraçăo do autor 
Sobre as estradas internas do assentamento Florestan Fernandes, são de terra, sem pavimentação e nem cascalho. Sua configuração não fez parte de um projeto específico, sendo aproveitado o traçado da antiga fazenda, que servia para o escoamento da produçáo de cana, gado ou outro tipo de monocultura da época (figura 37). Este desenho, na lógica de exploraçáo do solo da antiga fazenda de fato traz consequências na mobilidade ao interior do assentamento, na organização das famílias enquanto comunidade e na produçáo agropecuária.

Já sobre o abastecimento de água, o INCRA encaminhou, em fevereiro de 2015, uma ordem de serviço para perfuração de cinco poços no assentamento (lotes 19, 23, 51, 148 e 158). Em março de 2015, a empresa Sales e Matta (Andradina) realizou a avaliaçáo nos lotes 23 e 158 para perfuraçấo dos poços. Porém, com esta iniciativa, com dois poços já instalados, o seu funcionamento dependia do fornecimento de energia elétrica, cuja rede começou a ser instalada em junho 2016, dois anos depois do início das obras do PNHR. Até 2016, o fornecimento de água ocorria por meio de duas caixas d'água já existentes, da época da antiga fazenda.

Até dezembro de 2015, quando previa-se concluir as obras do empreendimento das 120 unidades habitacionais, a rede de energia elétrica ainda náo havia sido instalada e apenas 2 , dos 5 poços do INCRA, haviam sido perfurados (porém sem funcionamento) (figura 36). A falta de energia teve um impacto significativo na etapa de cobertura, sendo gastos em torno de $\mathrm{R} \$ 2.400,00$ por unidade, incluindo a montagem e a instalaçáo dos componentes. Devido à falta de energia no assentamento, as peças das estruturas metálicas foram descarregadas no lote 84 que, além de já ter um poço de água da antiga Fazenda Retiro, também possui energia elétrica.

A ausência de energia no assentamento implicou num gasto com geradores para as betoneiras e outros equipamentos utilizados nas 120 casas. Foram utilizadas 2 betoneiras movidas a gasolina e, para cada casa, foram gastos $20 \mathrm{~L}$ de combustível (incluindo também o combustível dos tratores utilizados para o transporte de materiais). Segundo o coordenador de obra e o representante da Empresa A, seria possível a economia de cerca de $\mathrm{R} \$ 50$ mil se a rede de energia já estivesse instalada no assentamento.

Figura 37. Infraestrutura para a assentamento Florestan Fernandes
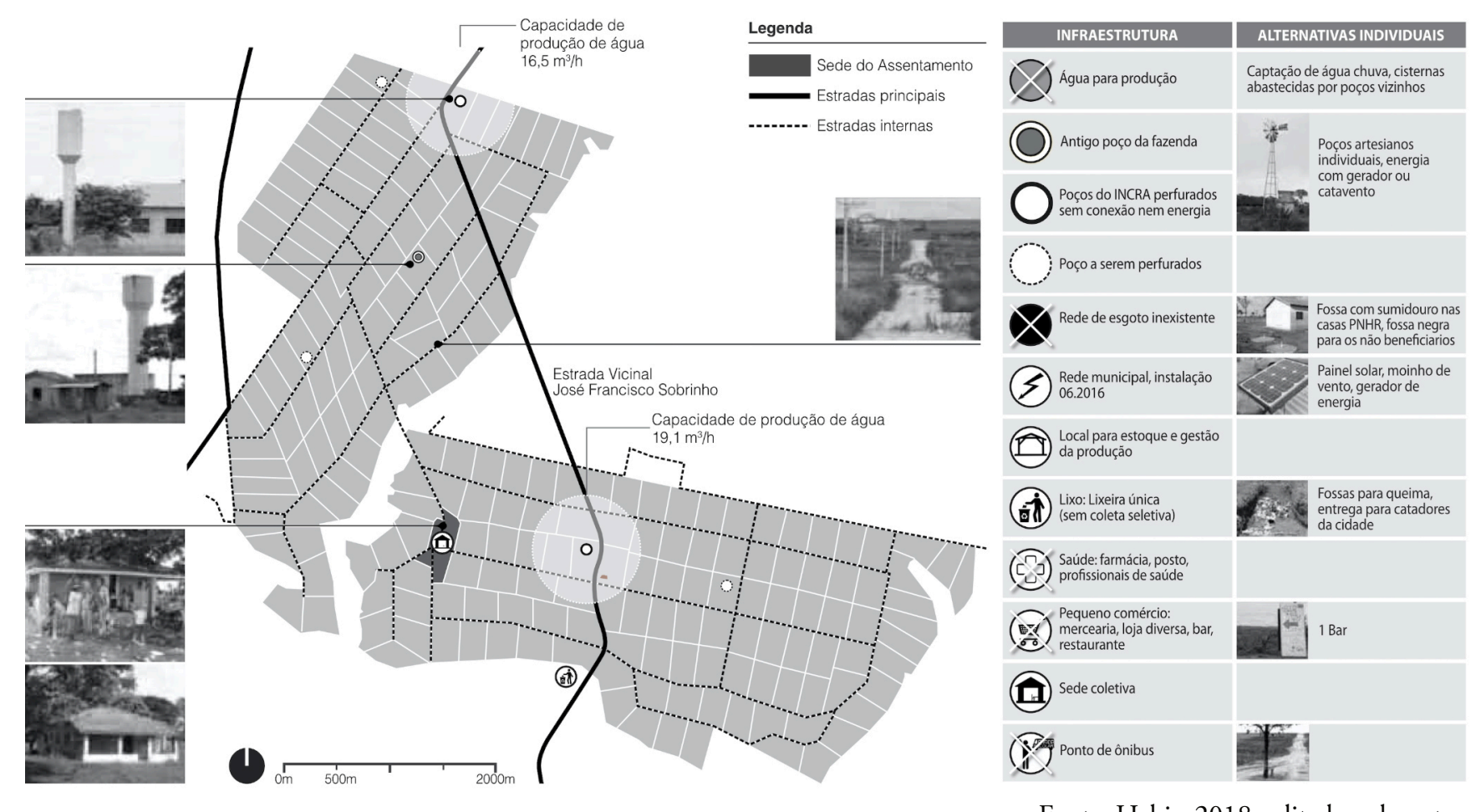

Fonte: Habis, 2018, editado pelo autor 
Assim como no processo construtivo das 120 casas, a falta de infraestrutura no assentamento também prejudicou as obras do empreendimento das 44 casas. O representante da Empresa B informou que a maior dificuldade de se construir em assentamentos rurais tem relação com a falta de energia. Por conta disso, as etapas de fundação (estacas cilíndricas e contrapiso) e vedação horizontal (laje convencional) foram executadas com concreto usinado fornecido pela CONCRESP, de Andradina. Com um sobrecusto evidente, o representante da Empresa B preferiu executar estas etapas com concreto usinado para agilizar a obra e evitar o aluguel de geradores. Já para as outras atividades do processo construtivo das 44 casas, foi necessário alugar geradores (movidos a gasolina).

O assentado do lote 135, que construiu sua casa sozinho, precisou comprar dois geradores - um de $\mathrm{R} \$ 3.500,00$ (a gasolina) e outro de $\mathrm{R} \$$ 1.800,00. Em dezembro de 2015, gastava R\$ 70,00/semana com gasolina para o gerador, que fornecia luz para a casa e enchia a caixa d'água. A perfuraçáo do poço semi artesiano em seu lote custou R \$ $6.050,00$ e a caixa d'água, $R \$ 3.800,00$.

Em dezembro de 2015, a rede de energia elétrica foi instalada pela concessionária no assentamento Boa Esperança -8 anos após as 46 famílias acessarem o PNCF. Também neste período, as estradas internas estavam cobertas com britas, porém alguns trechos encontravam-se com erosôes. Em junho de 2016, as famílias reivindicaram à prefeitura de Pacaembu ${ }^{38}$ uma nova manutenção, pois as condiçōes das estradas se agravaram com as chuvas.

Segundo informaçôes do representante da EO, os poços coletivos tiveram um custo total de R $\$ 70$ mil e foram financiados com recursos do SIB/PNCF. Em 2015, cada família que morava no assentamento gastava aproximadamente $R \$ 240,00$ por mês para extrair água do poço para seus respectivos lotes — já que a conexão entre os poços e as casas ainda não havia sido realizada por falta de recursos.

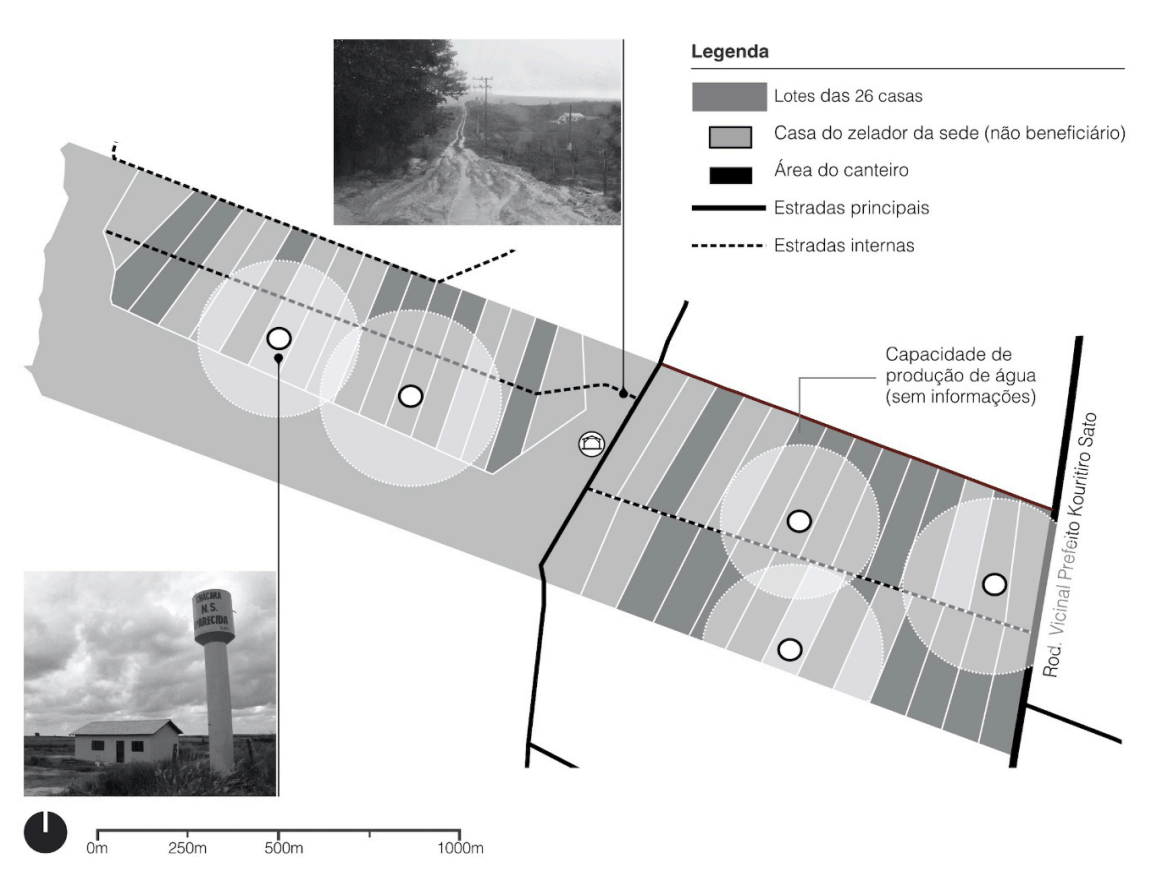

$\mathrm{Na}$ avaliaçáo do representante da Empresa C e da EO, a maior dificuldade ao longo do processo construtivo das 26 casas esteve relacionada à falta de energia no assentamento, tendo sido necessário alugar geradores movidos a gasolina — provocando gastos adicionais com a compra de combustível. Desta forma, para compensar a falta de água e energia no assentamento, a Empresa $\mathrm{C}$ providenciou a préfabricaçáo, em concreto armado, de reservatórios cilíndricos do sistema de tratamento de esgoto e de vigas de suporte da caixa d'água (figura
Figura 38. Infraestrutura para a produçăo habitacional do
assentamento Boa Esperança

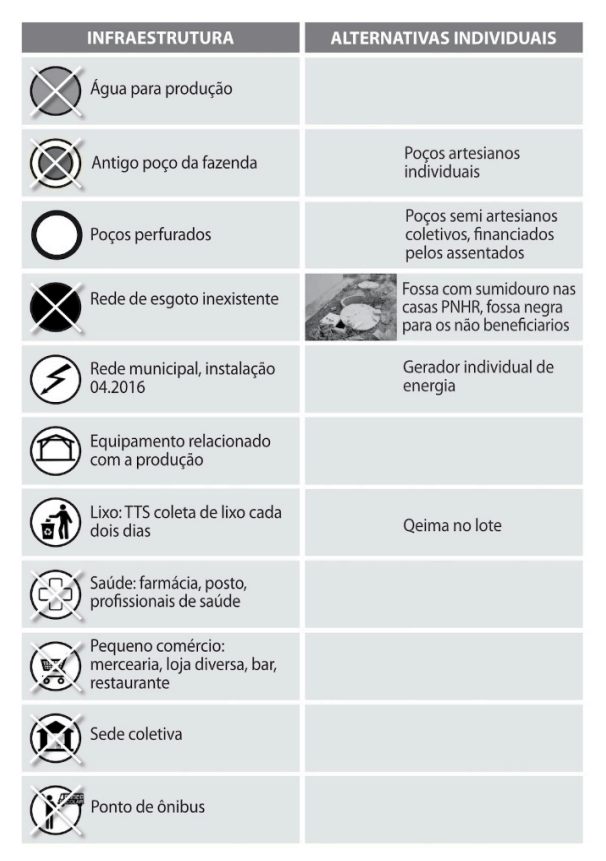

Fonte: Habis, 2018, editado pelo
autor 
39). Para a fabricaçáo in loco de concretos e argamassas, a Empresa $C$ alugou betoneiras, cuja alocação nos canteiros foi organizada de acordo com as empreitas. Para este processo de pré-fabricaçáo de componentes construtivos, a Empresa $\mathrm{C}$ alugou um galpão localizado na área urbana do município de Pacaembu. Ele foi alugado pela construtora exclusivamente para gerenciar os empreendimentos em andamento no estado de São Paulo. Além do pátio externo para a pré-fabricação, o galpão também possuía uma área reservada para o estoque de materiais construtivos e um escritório administrativo, onde trabalhavam dois técnicos. Ao todo, segundo informaçōes do técnico entrevistado, a empresa possuía 15 funcionários contratados para acompanhar os empreendimentos que, na época, estavam em andamento distribuídos em 06 municípios do estado.

Figura 39. Galpão alugada pela
Empresa C localizada em acaembu: estoque de materiais (acima); pre--abricacáa de
componentes (abaixo) Fonte: Habis, 2015

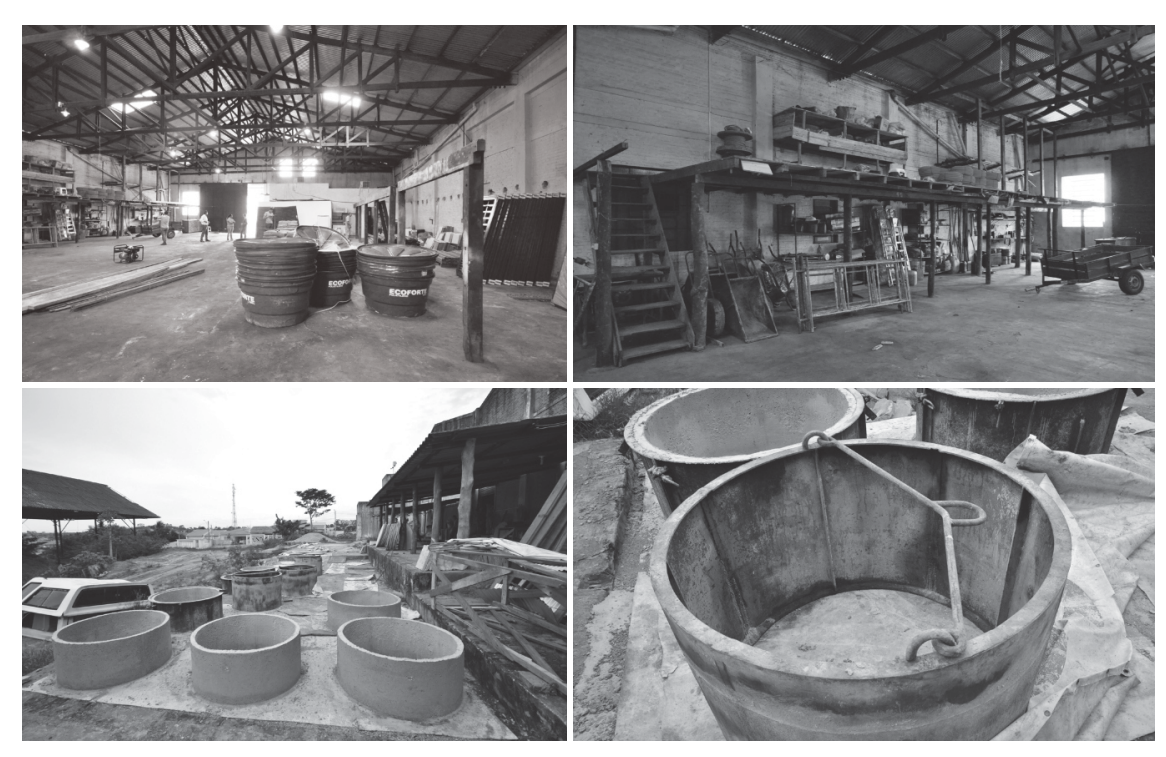

Em fevereiro de 2013, o INCRA autorizou a perfuração de 6 poços nos lotes 04, 35, 87, 124, 125 e 165 do assentamento Dona Carmem. O início das obras aconteceu em setembro de 2013 e a vistoria de conclusão foi realizada entre 16 e 17 de dezembro do mesmo ano. Porém, os outros dois poços instalados pelo INCRA (figura 40), permaneciam sem funcionamento até junho de 2016

Figura 40. Infraestrutura para a produção habitacional do
assentamento Dona Carnem
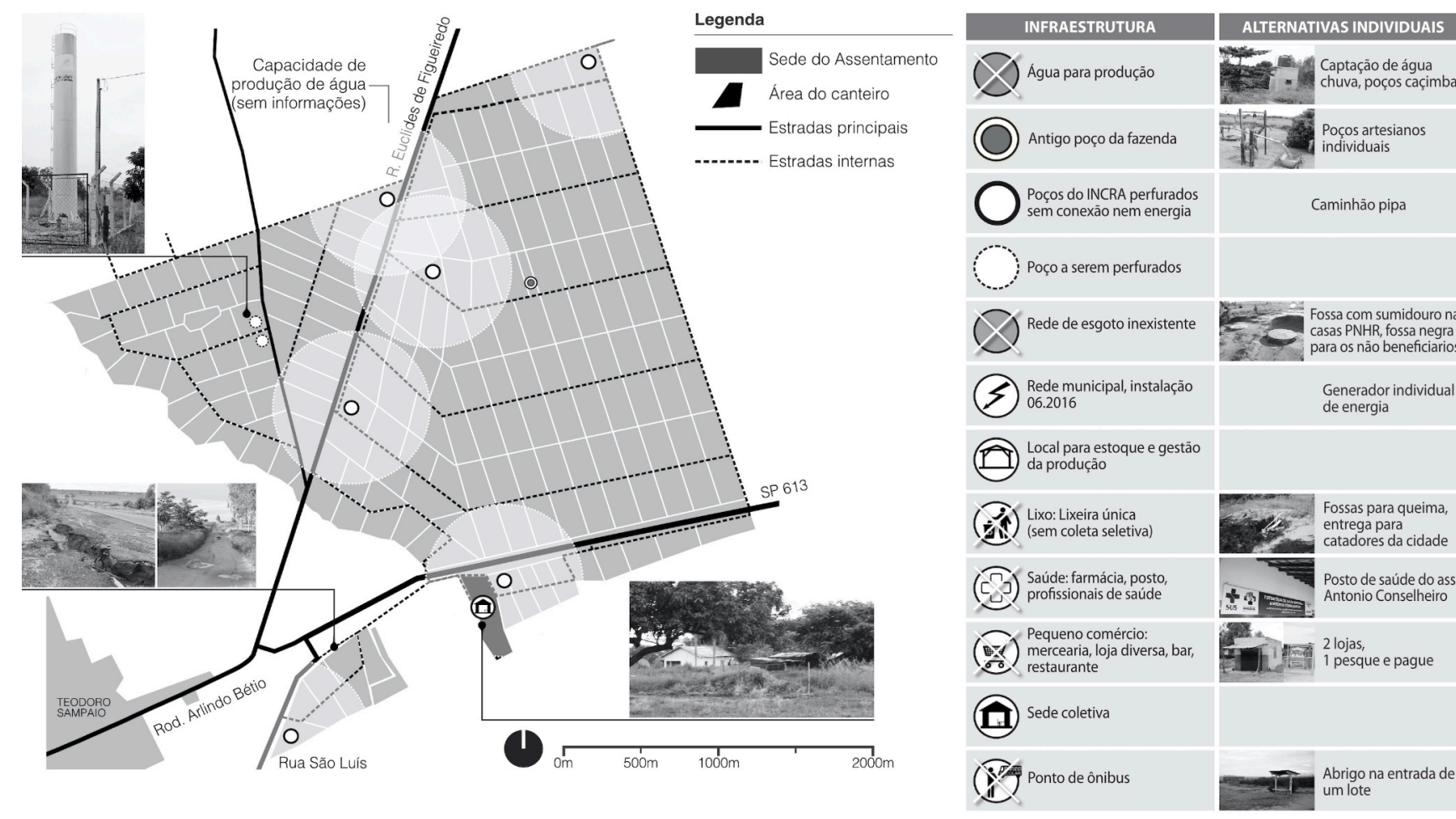

De acordo com um dos moradores do assentamento, a perfuração de um poço artesiano no assentamento custava, aproximadamente, $R \$ 8$ mil (ano de referência - 2015). A máo de obra para perfurar um poço cacimba custa $\mathrm{R} \$ 30,00 \mathrm{o} \mathrm{m}^{2}$. Em algumas zonas do assentamento, os poços cacimba possuem, em média, $20 \mathrm{~m}$ de profundidade. Ele disse que cada poço perfurado naquela área custava em torno de $\mathrm{R} \$ 1.400,00$ (mấo de obra e material). 
Já para o processo construtivo, foi necessário puxar água dos poços cacimba, perfurados pelos assentados em seus respectivos lotes. No entanto, as chuvas danificaram alguns destes poços que estavam sendo utilizados para o fornecimento de água. "Fizemos as casas praticamente sem água". O INCRA terceirizou os dois poços de água para a prefeitura de Mirante. No entanto, a prefeitura só iria executar o trabalho se o INCRA liberasse o recurso, o que náo aconteceu (pelo menos, até junho de 2016). Em julho de 2015, um dos encarregados da produçáo habitacional disse que a energia estava programada para ser instalada em 45 dias (início de setembro).

\section{A persistência da manufatura frente à} racionalização dos processos

Intrinsecamente relacionada ao trabalhador e ao processo de trabalho na construçáo habitacional, reside a questáo do sistema construtivo e dos materiais empregados. Afirmo isto náo necessariamente pelo conteúdo técnico propriamente dito, e sim a respeito da sua estrita associaçáo com o "saber-fazer" e a formação prática no canteiro de obras de caráter manufatureiro.

\subsection{A alvenaria e a permanência da manufatura}

Como já vimos, para os cinco contratos estudados, os sistemas construtivos predominantes não trazem muitas inovaçôes em termos de materiais, processos ou organização em canteiro. Porém, existem algumas particularidades que definem o trabalhador e sua posição no processo de produção, a serem revisadas.

Em primeiro lugar, no empreendimento das 120 casas, foi usado como sistema construtivo a alvenaria autoportante tradicional com blocos cerâmicos de 8 furos. Esta tecnologia construtiva largamente usada na habitação social brasileira é usualmente executada em construçōes mais simples (casas térreas ou com poucos pavimentos). Neste sistema, apesar da posiçáo inadequada em que foi assentado o bloco (com as cargas atuando no sentido transversal aos furos, a capacidade resistente do bloco cai para metade), é usada a alvenaria com funçáo estrutural, dispensando a construção de vigas e pilares e, inclusive, prescindindo de amarraçáo nos cantos (figura 41). Na última fiada da parede (sobre as alvenarias internas e externas) foi assentada uma canaleta de concreto, por onde passa a ferragem que seria concretada e exerceria a funçáo de cinta de amarraçấo. É o mesmo sistema usado para a execução da verga das portas e janelas.

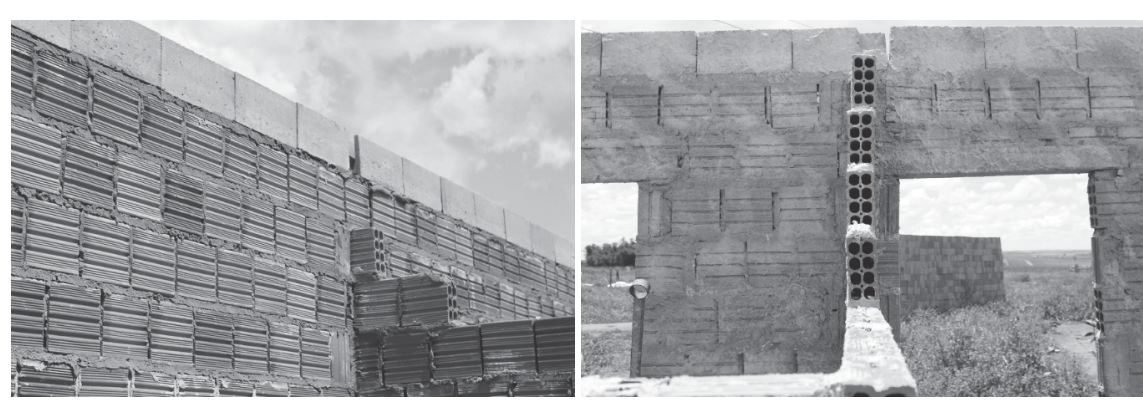

Conceitualmente, o tipo de alvenaria cerâmica autoportante tradiciona traz alguns aspectos a serem revisados. Segundo a Comunidade da Construçáo (2008), é caracterizada por elevados desperdícios, adoçáo de soluçóes construtivas no próprio canteiro de obras (no momento da realização do serviço), ausência de planejamento e de fiscalização dos serviços. Diferente da estrutura convencional, composta por pilares e
Figura 41. Sistema construtivo autoportante com bor
cerâmicos de 8 furos Fonte: Habis, 2015 
vigas de concreto armado e vedaçáo em tijolo ou bloco, este sistema não envolve as armaçôes em ferro dos pilares e, consequentemente, há a necessidade da construçấo de formas para "moldar" esta estrutura independente da vedação.

Então, ao eliminar atividades de armação e de carpintaria na execução de fôrmas, estaria afetando a tradição manufatureira? De fato, há uma diminuiçấo na participaçáo do trabalhador que operava nesses processos, principalmente do carpinteiro. Dando, assim, um maior protagonismo ao assentamento de blocos. Vale a pena deixar claro que não é o mesmo "assentador de alvenaria estrutural", aquele novo profissional descrito por Baravelli (2014):

[...] "bloqueiro" - é um profissional notoriamente distinto em relação aos demais ofícios da construuçáo, de imediato porque combina sua atividade com a instalaçáo de tubos e eletrodutos embutidas nos blocos e o corte e
colocaçăo de armaduras, mesmo que simplificadas, em vergas,

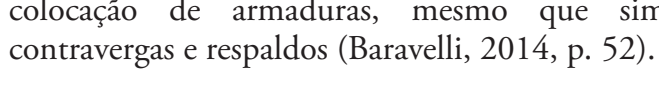

Devemos distanciar o sistema implementado no empreendimento estudado daquele de alvenaria de bloco estrutural. Neste, é usado um tipo de bloco produzido em fábricas, com altos padrōes de precisão, característica que possibilita um nível de racionalidade que náo encontramos em sistemas convencionais.

Quando mencionamos que, no contrato das 120 casas, há um maior protagonismo no processo de assentamento de blocos, é porque, na prática, esta etapa construtiva nấo depende exclusivamente de um projeto detalhado, que define a combinaçáo precisa de peças prontas de alvenaria (por exemplo, o bloco inteiro, canaleta e meio-bloco). Neste caso, esta etapa depende do "saber-fazer" do trabalhador. Isto se considerarmos as difíceis condiçóes dos canteiros de obra dispersos, a distância destes canteiros rurais das cidades, a ausência de ferramentas e máquinas suficientes e as características do material (muitas vezes, de má qualidade), condições que devem ser resolvidas pelo trabalhador diretamente no canteiro.

Segundo Farah (1996), uma das características do processo de trabalho na construçáo tradicional diz respeito ao preparo dos materiais e componentes. Ou seja, há situaçôes em que, sem dúvida, demandam uma maior intervençáo autônoma do trabalhador. Uma vez que, embora os materiais sejam fornecidos em sua forma final pela indústria, é necessária uma intervenção adicional no canteiro de obras, anterior a seu uso na construçáo propriamente dita (FARAH,1996). Neste caso, (assim como o preparo do cimento, por exemplo) os blocos devem ser quebrados pelo pedreiro, já que suas medidas náo são compatíveis com as dimensōes das paredes definidas pelo projeto.

Conforme o caso anterior, na construçấo tradicional, as condiçóes descritas e a preparaçấo de elementos no canteiro de obras implicam no desenvolvimento de múltiplas atividades ou operaçóes de apoio. Em segundo lugar, a manufatura pressupóe o saber do trabalhador, ou seja, depende de suas habilidades e das ferramentas, diferente do trabalhador industrial, na qual quem determina os tempos e ritmos da produção é a maquina.

Na manufatura e no artesanato, $o$ trabalhador se serve da ferramenta; $n$ fabrica, ele serve à máquina. La, o movimento do meio de trabalho parte dele; aqui, ao contrário, é ele quem tem de acompanhar o movimento. $\mathrm{Na}$ vivo. Na fábrica, tem-se um mecanismo morto, independente deles e ao qual são incorporados como apêndices vivos" (MARX, 2002, p. 606). 
Já sobre os outros empreendimentos estudados (das 44 casas em Florestan Fernandes, das 26 casas em Boa Esperança e das 27 e 10 casas em Dona Carmem), podemos perceber unidades construídas com estrutura em concreto armado e alvenaria de vedação (figura 42) que, além de ser necessária uma certa habilidade no processo de assentamento de blocos, são acrescentadas atividades de armaçóes em ferro e carpintaria, mesmo que sejam simples. Porém, com o uso de instrumentos de trabalho para o preparo e execuçáo destes componentes, ferramentas manuais especializadas associadas aos diferentes "ofícios" como o serrote, o martelo, a trena etc. Esta se constituiria numa outra característica do processo do trabalho na construçáo tradicional que, segundo Farah (1996), consiste no predomínio do trabalho manual como base produtiva.

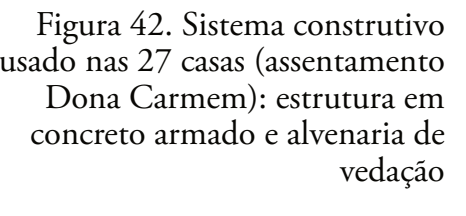

Fonte: Habis, 2015

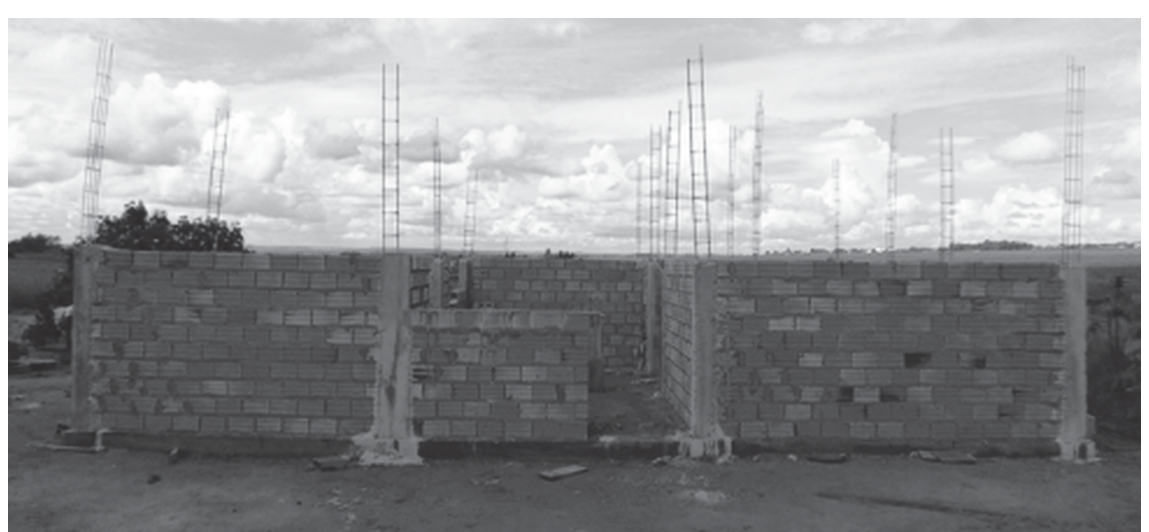

A habilidade necessária para desenvolver este tipo de atividades manuais no processo de trabalho - como armaçóes em ferro e carpintaria na montagem das formas, dentre outras - corresponde à parcelizaçáo do saber, ou seja, à especialização dos trabalhadores na execuçáo das atividades de manuseio e transformaçáo de materiais e componentes associados à execuçáo das partes da edificaçáo. Vale a pena destacar que estes ofícios se diferenciam do artesanato, uma vez que não abrangem a totalidade do processo de produção, mas se restringem à execuçáo de partes de um processo de trabalho, cujo sentido é necessariamente coletivo, remetendo à cooperação entre trabalhadores responsáveis por atividades complementares (FARAH,1996).

Desta forma, uma das principais características do processo produtivo manufatureiro é a acumulaçáo sucessiva de atividades. No caso das edificaçóes habitacionais, inicia-se com a instalaçáo do canteiro de obras, pela execuçấo das fundaçốes e continua com a estrutura, vedação, instalaçôes, revestimentos etc. Segundo Farah (1996), estas etapas são constituídas por atividades consideravelmente diversificadas, envolvendo a incorporaçáo ao processo produtivo de uma grande variedade de materiais e componentes que requerem, por sua vez, instrumentos de trabalho também diferenciados para sua transformaçấo. A existência desta separação das equipes de trabalho durante todas as etapas da obra aponta para o que seria - segundo a denominação marxista - a base produtiva do tipo "manufatura serial".

Este conceito é trazido pelo Sérgio Ferro (2006) no texto "Sobre o canteiro e o desenho", no qual coloca a construção da época como uma produçáo marcada pela organizaçáo manufatureira. Ele faz uma distinção com a "manufatura heterogênea", que se refere à montagem de peças produzidas em fábricas e que náo obedece a uma sucessão acumulativa de trabalho (destacando o caso francês). Já para o caso do canteiro de obras brasileiro, 0 autor coloca o trabalhador como 
elemento imprescindível que faz parte de uma sequência lógica de equipes especializadas que executam as tarefas no canteiro, processo sempre na submissão formal do trabalho.

A submissão formal do trabalho numa produçấo quase sempre elementar réquer uma boa dose de irracionalidade técnica - mas que, desse modo, na própria alma do processo produtivo manufatureiro: ela é de tal forma banal, evidente que, a descoberto, tornaria a submissão arriscada. Ora, essa alma é a sequência lógica das equipes especializadas, ponto final. Quase todo projeto, portanto, embaralha, retorce, mistura, obscurece essa sequencia $-e$ o alvo inconsciente do desenho separado. Em meus cursos
sobre projeto, constantemente digo isto: uma plástica da sequência lógica das equipes é um (pequeno) passo indispensavel para superar a atua relaçăo de exploraçāo no canteiro de obras (FERRO, 2006, p. 345).

Na prática, os serviços executados de modo sequencial, como é o caso das empreitas estudadas, é o pedreiro o primeiro profissional a intervir no processo de fechamento, é ele quem assenta os blocos para elevar a alvenaria e também executa a estrutura (vergas, pilares e contra vergas, dependendo do sistema). Depois de levantadas as paredes, são feitos cortes - literalmente quebrando a parede - para a passagem dos conduítes e as caixinhas das instalaçóes elétricas, para, depois, o encanador quebrar as paredes para instalar as tubulaçóes de água e esgoto (figura 43). Desta forma, passa de novo o pedreiro - ou o servente - para cobrir (preencher) com argamassa o encanamento.

Todo este processo de inevitáveis retrabalhos - e talvez, como destaca Ferro (2006) com uma dose de irracionalidade técnica — durante todas as etapas destas obras, é finalmente "coberto" por múltiplas camadas de revestimento (chapisco, emboço e reboco) — atividades que poderiam ser consideradas a maior manifestaçâo da habilidade de um pedreiro.
Posteriormente, é o pedreiro quem faz o revestimento interno das paredes, isto sem considerar a pintura e o forro, cada uma destas atividades requer habilidades especificas.

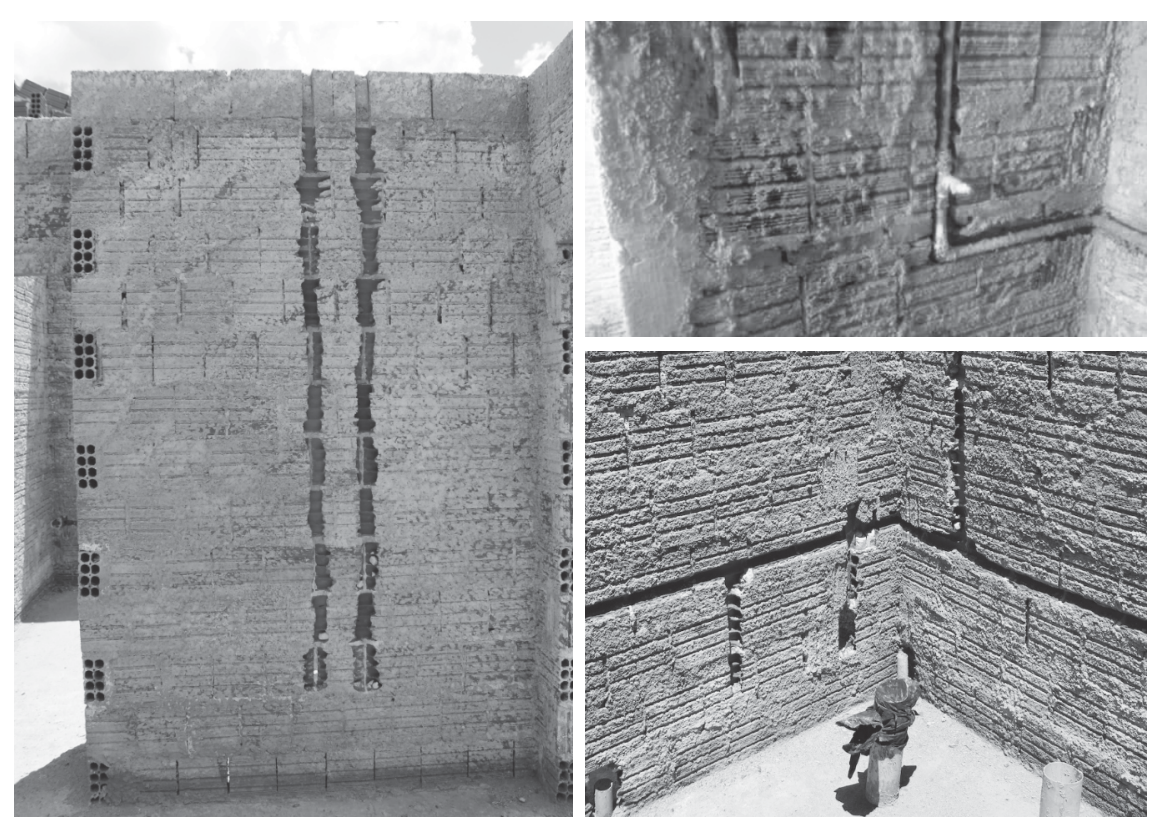

9.2. Concreto usinado e racionalizaçáo

Após o vendaval occorrido no local do contrato das 120 unidades (Florestan Fernandes), no qual 17 casas sofreram a queda de boa parte da alvenaria levantada, surgiu a proposta de mudar as fundaçóes do contrato das 44 unidades, projetadas inicialmente com alvenaria de pedra argamassada e cinta de concreto armado, por fundaçóes em estaca cilíndrica, com $20 \mathrm{~cm}$ de diâmetro e 3 metros de profundidade. Segundo as famílias e inclusive a AT, este sistema poderia evitar que o vento, que é muito forte, "levantasse a casa" (figura 44).
Figura 43. Cortes na alvenaria para passagem de instalaçóes, 120
unidades (esq) e 44 unidades (dir) Fonte: Habis, 2015 
Para esta "soluçáo" de fundaçóes em estaca, assim como para a laje e o contrapiso de cada unidade habitacional, foi adotado o uso de concreto usinado, com valores muito acima do orçamento inicial. Somente as fundaçóes custariam $\mathrm{R} \$ 11.000,00$ por unidade (materiais e MO), contra os $\mathrm{R} \$ 2.298,83$ do projeto original. Porém, a justificativa apresentada pela Empresa B foi obter um maior controle do ponto de vista da qualidade do produto, a eliminaçáo da estocagem dos respectivos insumos dentro do canteiro de obras e, enfim, uma maior produtividade.

Figura 44. Projeto original de esceos (ess); fundaçoes en
estir) (44 unidades)

Fonte: Habis, 2015
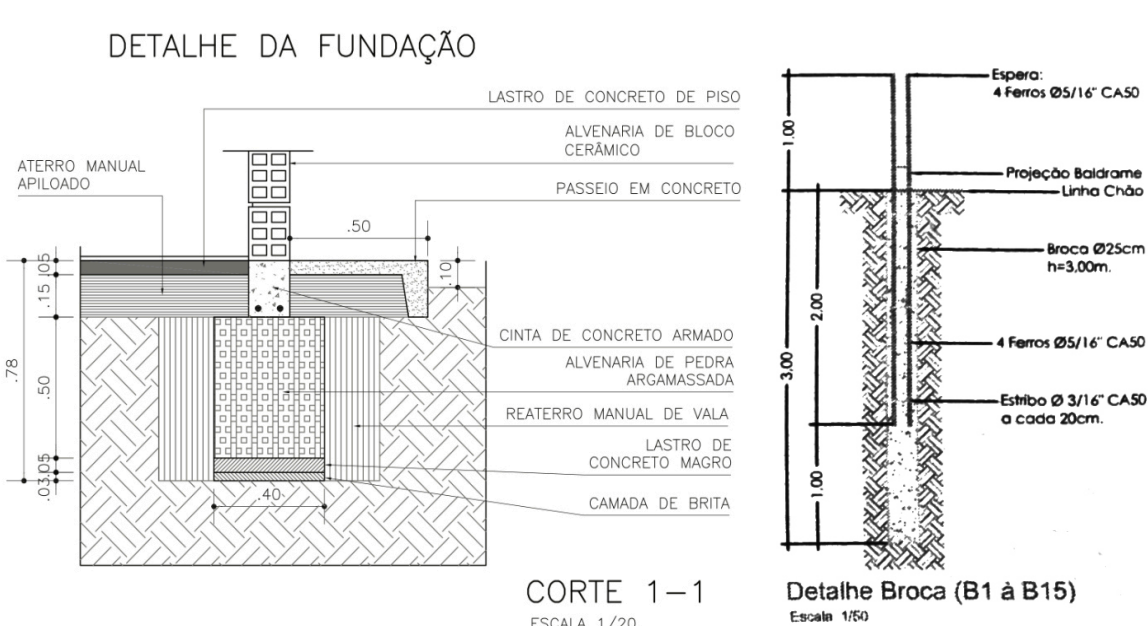

CORTE 1-1

Detalne Broca (B1 à B15)

Como já mencionamos anteriormente, a diferença da manufatura, o avanço do processo industrial pressupóe o aumento da "racionalizaçáo do processo de produçán e, consequentemente o minimo de intervenção do trabalhador. Desta forma, Marx explica este fenômeno ao final do primeiro volume do "Capital", a partir da "lei geral da acumulação capitalista”, segundo a qual:
[...] uma massa cada vez maior de meios de produçăo, graças ao progresso da produtividade do trabalho social, pode ser posta em movimento com
um dispêndio progressivamente decrescente de força humana, é expressa no terreno capitalista - onde nãa é o trabalhador quem emprega os meio

Segundo a afirmação de Marx, o processo de acumulação de capital não está orientado, necessariamente, para o aumento da produçáo, e sim no sentido do aumento da produtividade. Como já vimos no caso estudado das 44 unidades, esta iniciativa está orientada pelo dispêndio cada vez menor de força de trabalho e com o processamento cada vez maior da matéria-prima.

Juntamente ao uso de concreto usinado, encontramos a adoçáo de armaduras pré-fabricadas (figura 45), tanto para as brocas de concreto como para as vigas baldrame. Esta decisão é justificada pela Empresa B pela reduçáo do custo das barras e pelo processo de produçáo das armaduras, ou seja, fazer os cortes e a dobra dentro do canteiro de obras tem um custo maior do que comprar pronto.

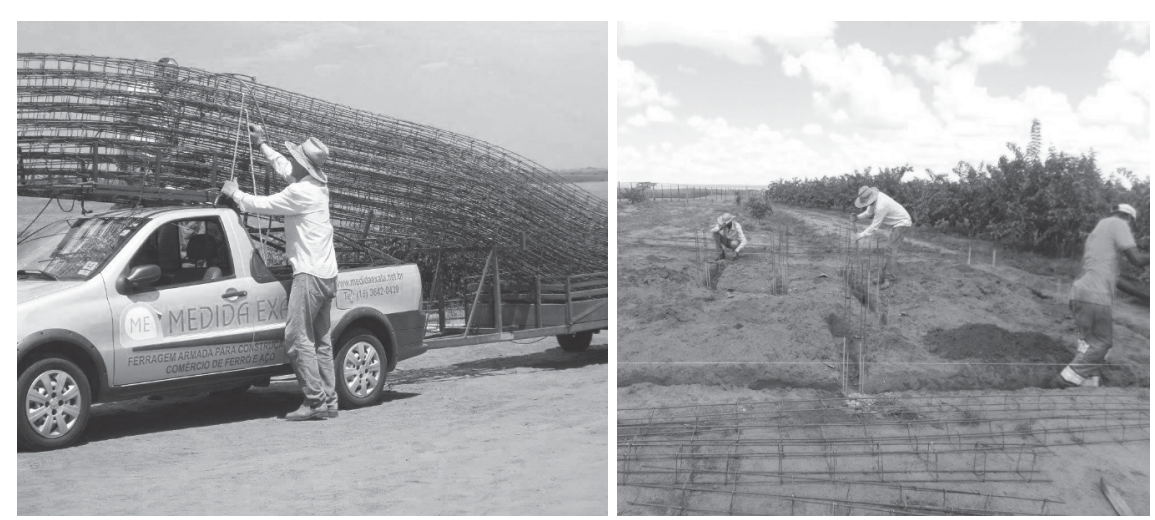

Figura 45. Fornecimento e fabricadas (44 unidades)

Fonte: Empresa B 
Esta iniciativa não altera apenas a quantidade de mấo de obra usada em canteiro com o uso do concreto usinado, como também existe uma crescente desvalorização das habilidades do trabalhador que, como já vimos, diferencia-se da subsunção formal presente — parcialmente na manufatura, que pressupóe ainda haver algum domínio nas mãos do trabalhador, a chamada subsunção real aparece na indústria, na qual a maquinaria se torna o centro do processo, assim, os tempos, as quantidades, os ritmos do processo de produção sáo dominados pela Figura 46. Concretagem das
brocas contrapiso e laje pelos óprios moradores (44 secundária.

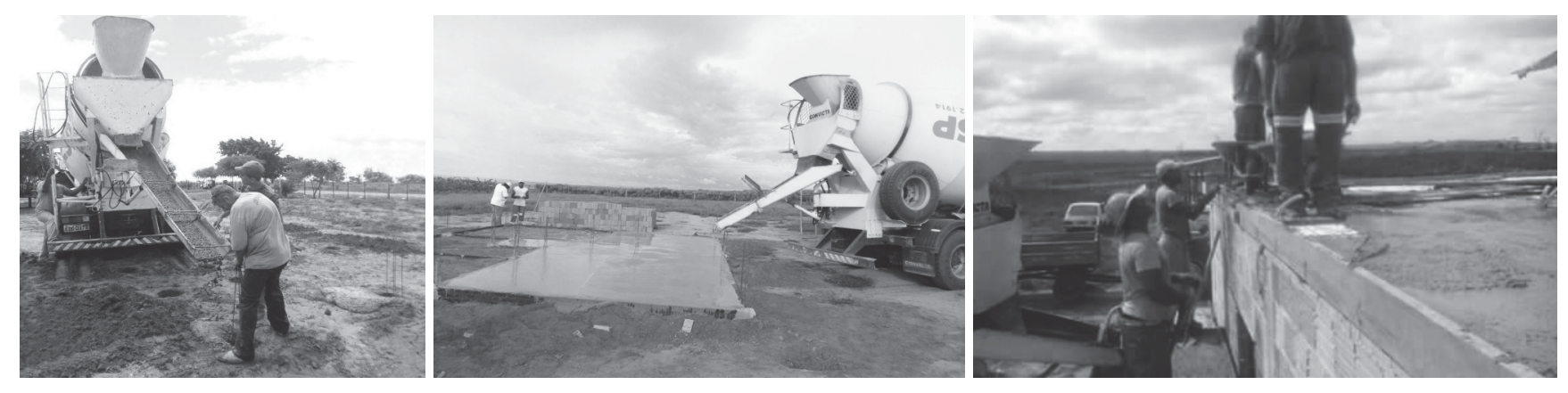

Fonte: Empresa B

$\mathrm{Na}$ prática, estas "simples", mas, de qualquer forma, endógenas condiçōes trazidas pelo componente tecnológico e organizativo, trazem certos aspectos que devem ser mencionados. Em primeiro lugar, a intensificaçáo da jornada de trabalho, pois, enquanto numa base produtiva do tipo "manufatura", há tempo de espera da massa (com múltiplas subtarefas), enquanto num processo mais "modernizado" o tempo de espera é reduzido. Além disso, modifica-se a própria organizaçáo do trabalho, visto que as atividades assumidas pelos trabalhadores na manufatura - como descarregar, peneirar e dosar os agregados, descarregar e movimentar os sacos de cimento, além da limpeza e manutençáo de ferramentas, caçambas, rodas e tambores deixam de existir, tendo que ser reorganizados o processo e a posição dos trabalhadores.

Apesar de se perceber um interesse de domínio do capital sobre a força de trabalho e uma busca constante pela produtividade, que termina prejudicando, por exemplo, os processos naturais de formaçáo a partir da prática no canteiro de obras - se consideramos que o regime construtivo definido para este contrato é a autoconstrução assistida o trabalho é ainda sedimentado sobre uma base estrutural da manufatura. A maioria dos equipamentos utilizados substitui a força muscular do operário, mas não as suas habilidades (VARGAS, 1983, p. 199). Segundo nossa compreensão, estas alteraçōes no processo de produção de moradia no campo náo determinam o fim da manufatura.

Embora haja cientifizaçáo da produçăo, embutida no projeto arquitetónico e nos projetos complementares (estrutura, fundaçóes intervếm com sua experiência prática, de um lado, traduzindo e adaptondo os projetos na fase de execucáo e, de outro, recorrendo a conhecimentos tradicionais na utilizaçăo e aplicação dos materiais e componentes (FARAH, 1996, p. 84)

Até mesmo o capital depende da experiência de encarregados e mestres, formados no próprio canteiro, assim como das relaçóes sociais inerentes aos processos produtivos para viabilizar a produção. Na prática, a forma como deve ser executado um trabalho, assim como "a constituiçáo de equipes, a programação e a alocação de tempos, o estabelecimento do ritmo de trabalho e o próprio controle da produçáo se dão no interio da forca de trabalho, sob a lideranç do mestre e do encarregado do ofício" (FARAH, 1996, p.84). 
10. A posição do campesinato, uma nova força de trabalho ou a preservação da sua autonomia

Sobre a autoconstruçáo da casa operária nas periferias das grandes cidades muito tem se falado e discutido. Trabalhadores pressionados que, por falta de alternativas, por náo conseguirem garantir aquele item "moradia" a partir do salário recebido, não encontram outra opção diferente a construir a própria casa, sendo obrigados a dedicar parte do seu tempo de descanso à construçáo do seu espaço, pois naquele tempo de assalariado é impossível. Sem escolha, estas camadas mais carentes da população sofrem, assim, com os efeitos negativos, enquanto superexploraçáo da força de trabalho e rebaixamento do seu salário Porém, é necessário considerar o contexto em que se dá este tipo de experiências, pois uma coisa é a autoconstrução individual e comumente utilizada de forma clientelista por diferentes governos, e outra, aquele tipo de mutiráo que parte de uma tradição rural brasileira de ajuda mútua, onde "você chama o compadre no fim de semana, toma uma cerveja, come uma lingüiça frita e vai fazendo a casa aos pouquinhos" (OLIVEIRA, 2006, p. 67). Nestes mutiróes, há um fortalecimento da organizaçáo popular, a construção de um conhecimento que se transmite socialmente e, assim como ressalta Sérgio Ferro, em termos práticos, a construção de sua moradia (não como mercadoria) com seus próprios instrumentos.

Nos feriados, fins de semana ou férias, quando ergue sua casa, o trabalhador produz para si. Náo como o faz diariamente, como força de mercadoria abstrata - força socialmente necessária - a produzir valores
Apesar de podermos encontrar similitudes, é necessário estabelecer diferenças com a produção da casa operária, pois, pelas relaçôes nãocapitalistas de produção em que comumente se desenvolve a vida camponesa, as consequências diferem da lógica da autoconstruçăo na cidade. Na qual, segundo Oliveira (2006, p. 68), torna-se um mecanismo de acumulaçáo primitiva, visto que o capital se reproduz com o rebaixamento do custo da força de trabalho ou, em outras palavras, com o rebaixamento do salário. Desta forma, a construçáo por ajuda mútua, dentro da realidade camponesa, não encaixa nessa lógica. Assim como a produçâo de alimentos para o sustento familiar, a autoconstruçáo da moradia camponesa se constitui num elemento para o consumo próprio e de sua família, o camponês é dono do seu tempo, pois não é um operário assalariado que vende sua força de trabalho, $\mathrm{e}$ por conseguinte, define quando e como produz.

Como já mencionamos nos itens anteriores, o regime construtivo adotado pelas EOs, em todos os contratos, foi a autoconstruçáo assistida, que pressupóe, além do incentivo ao trabalho coletivo e a construçáo de novas sociabilidades, uma forma de organização política, estabelecendo um novo patamar de relaçáo das comunidades com o Estado, uma vez que consolidariam-se novos sujeitos sociais responsáveis pela administraçáo de recursos e do gerenciamento da obra. 
Contudo, as relaçốes sociais de produçáo encontradas nos canteiros estudados são muito diferentes do que esperaríamos, somos cientes de que a autogestáo que encontramos nestes empreendimentos não se apresenta de forma plena. Após aproximaçóes nos canteiros, percebemos sinais de certos vínculos com formas de produçáo de caráter capitalista como, por exemplo, a realidade em que expóe relaçôes de trabalho praticadas pelas empresas construtoras que, com o objetivo de fazer avançar a obra, contrata em paralelo à autoconstrução, mão-de-obra remunerada.

Fica evidente a incompatibilidade da autoconstrução neste cenário que - ainda que parcial - fica refém das regras do programa habitacional. Isto se considerarmos que, em primeiro lugar, enquanto o programa determina uma porção do orçamento total para a remuneração da máo de obra na construção das habitaçôes numa tentativa de construçáo de autonomia, o conjunto das famílias escolhe a autoconstrução como regime de contrataçáo que, convenientemente, acaba se configurando para as empresas construtoras - como uma saída para absorçâo de máo de obra não qualificada, com camponeses desenvolvendo um trabalho no canteiro de obras essencialmente braçal (figura 47), situação que se traduz em uns dos meios para a subsunçấo do campesinato ao capital.

Figura 47. Moradores do asse

suas próprias casa

Fonte: Habis, 2016

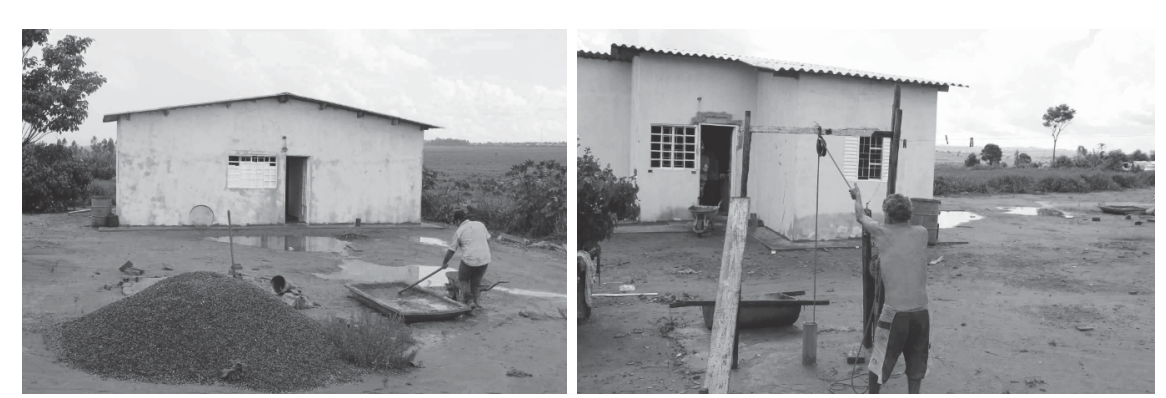

Além disso, a pesquisa empírica demonstra que, apesar de contar com um valor consideravelmente maior do que os programas anteriores ${ }^{39}$, na prática, 30\% é direcionado para o pagamento do trabalhador (que, para nossos casos de estudo, corresponde a cerca de $\mathrm{R} \$ 11.550,00^{40}$ ) e é insuficiente para construir uma casa de $61 \mathrm{~m}^{2}$, como é o caso das 120 casas de Florestan Fernandes. Em nosso entendimento, estas condiçôes possibilitam a extraçáo de mais-valia associada ao processo de exploração da máo de obra assalariada. Trata-se de um processo de apropriação do trabalho excedente como lucro.

Somado às condiçóes impostas pelo programa, após conversas com um dos pedreiros desse contrato (que é assentado e também morador ${ }^{41}$ ), percebemos o rebaixamento da remuneraçăo da máo de obra, só pelo fato de se desenvolver num assentamento rural. Além do trabalho no seu próprio lote, este assentado sempre trabalhou como pedreiro, desde que era morador do município de Lavínia. Os valores de mão de obra recebidos por ele, por unidade, foram $\mathrm{R} \$ 2.000,00$ (alvenaria até o oităo) e R \$ 2.500,00 (reboco das paredes e instalaçáo das esquadrias). Com relaçáo aos valores de máo de obra pagos neste projeto habitacional, o assentado destacou que a remuneração dos trabalhadores da construção no assentamento era consideravelmente mais barata do que na cidade. "Aqui, o metro quadrado do piso sai por $\mathrm{R} \$ 7,00$; na cidade, o mesmo serviço sai por $\mathrm{R} \$ 27,00$ ”.

De alguma maneira, este rebaixamento é explicado ao interior do mesmo Programa Nacional de Habitação Rural, vinculado ao "Minha Casa Minha Vida" - PNHR/MCMV. Entendemos que no processo de produçáo do seu habitat, os territórios rurais e urbanos enfrentam
39. Como colocado na exemplo, o PSH-Rural (uma das três linhas de acessos a recursos do Programa Nacional de Habitaçio
Rural na sua primeira versán 2003-2009) disponibilizava apenas $\mathrm{R} \$ 4.500,00$ por família. Ou seja, seis vezes menos do que o atual programa PNHR, que
disponibiliza $R \$ 28.500,00$ para Nordeste, Centro-Oeste, Sudeste e Sul do país.

40. Isto quer dizer $30 \%$ de $\mathrm{R} \$$ $+\mathrm{R} \$ 10.000,00$ Casa Paulista). Em alguns contratos, optaram até mesmo por usar apenas os para o pagamento deste item
$(25,97 \%)$.

41. Na época, este assentado era
um dos coordenadores do ssentamento, representando as
famílias vinculadas ao SINTRAF. Segundo ele, esta experiência (de
coordenador) vinha sendo "humilhante e desgastante". assentado náo havia sido contemplado pelo PNHR por em Mirandópolis. De acordo con ele, houve uma tentativa de transferência da escritura do imóvel para outro membro do seu
grupo familiar, mas essa tática não ocorreu em tempo sufficiente para que o seu nome deixasse de constar no Cadastro Nacional de 
dificuldades semelhantes, porém, como já mencionado, os recursos para provisão de habitação camponesa são muito menores do que os disponibilizados na cidade. Os valores de construção definidos para os agricultores familiares beneficiários do Programa Nacional de Reforma Agrária (PNRA), com renda anual de até $\mathrm{R} \$ 15.000,00$, são de $\mathrm{R} \$ 28.500,00$ a $\mathrm{R} \$ 30.500,00$, dependendo da regiáo do país. Segundo Lopes et al. (2017), no seu equivalente urbano, o MCMV-Entidades, os valores praticados em 2016 podiam chegar a aproximadamente R\$80.000,00, (este valor é resultado da exclusáo de uma estimativa da parcela para aquisiçăo do terreno), esta situaçáo, segundo os autores:

Grosso modo (...) acaba insinuando que o camponês é (...) "menos
cidadáo" que seu correlato urbano. Concede-lhe assim a incômoda, porém
estratégica condicão de um "cidadão de segunda ordem" - incômoda estratégica condiçáo de um "cidadáo de segunda ordem" - incômoda, porque năo é fácil ver-se destituido de, pelo menos, o que seu
companheiro da cidade dispóe; estratégica, porque mantê-lo reduzido ao seu lugar na sociedade é sempre uma questão funcional (LOPES et al. 2017, p.5).

Além disso, a imposiçáo da forma de produção e dos padróes construtivos desenhados pelo programa e sua combinação com formas de produção baseadas na cooperação por ajuda mútua trazem implicaçóes nas diferentes realidades do campo. Encontramos nos empreendimentos estudados cronogramas de construçáo que não consideram o calendário agrícola e os períodos de safra e entressafra, ou seja, as dinâmicas de trabalho no campo que determinam os tempos em que as famílias se dedicam para a produção agrícola e sua comercialização e a divisão de tarefas definidas no interior da família camponesa. Neste aspecto, é destacada a necessidade de se entender a dinâmica própria do campo para verificar a incompatibilidade da autoconstrução nestas condiçóes.
Ao longo das conversas nos diferentes canteiros, vimos o rebaixamento dos camponeses da reforma agrária a uma cidadania de segunda ordem, com empresas construtoras amparadas no próprio funcionamento do programa habitacional. Programa que, de um lado, promove a precarizaçáo do trabalho, degradante e sem quaisquer garantias de direitos trabalhistas e, de outro, obriga as famílias ao trabalho voluntário, e não coletivo - a essência da construção por ajuda mútua - com camponeses submetidos às condiçôes de produtividade impostas pela construtora. Isso faz com que os agentes (futuros moradores), que deveriam ser os beneficiários da política social, internalizem todas as suas precariedades e passem a ser explorados por ela. Resta agora, segundo as reflexôes colocadas pelo Oliveira (2006, p. 69), questionar se esses processos de precarizaçáo têm alguma significacăóo e, se nestas condiçôes, poderíamos falar que a acumulaçáo de capital repousa uma de suas pernas sobre a autoconstruçáo. 


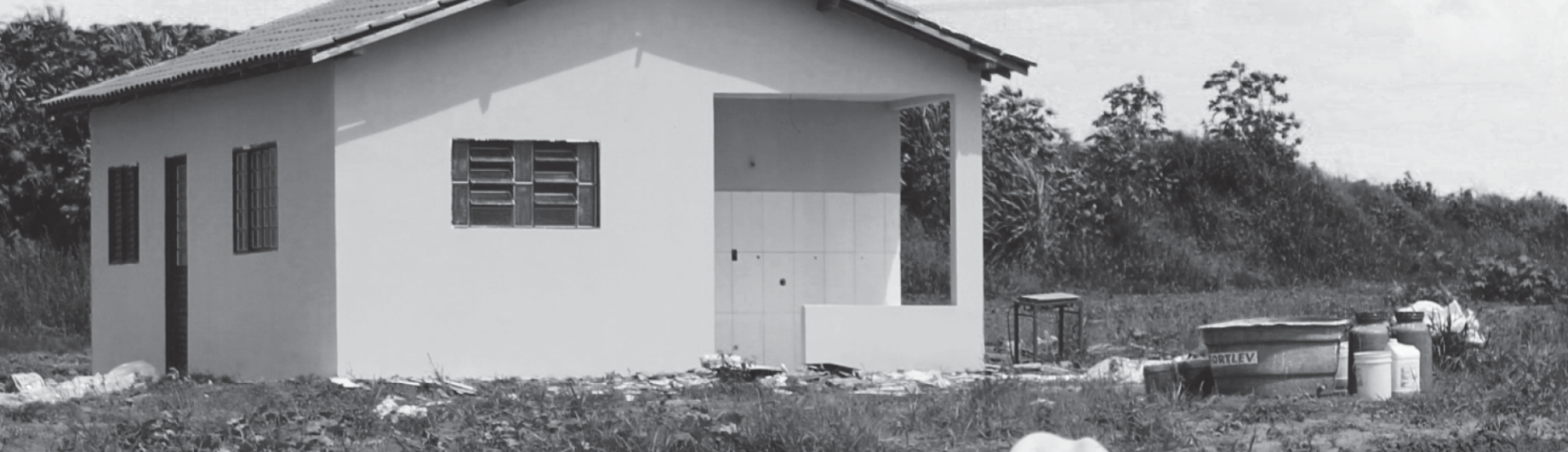

\section{CAPÍTULO III I O projeto e a construção} da autonomia

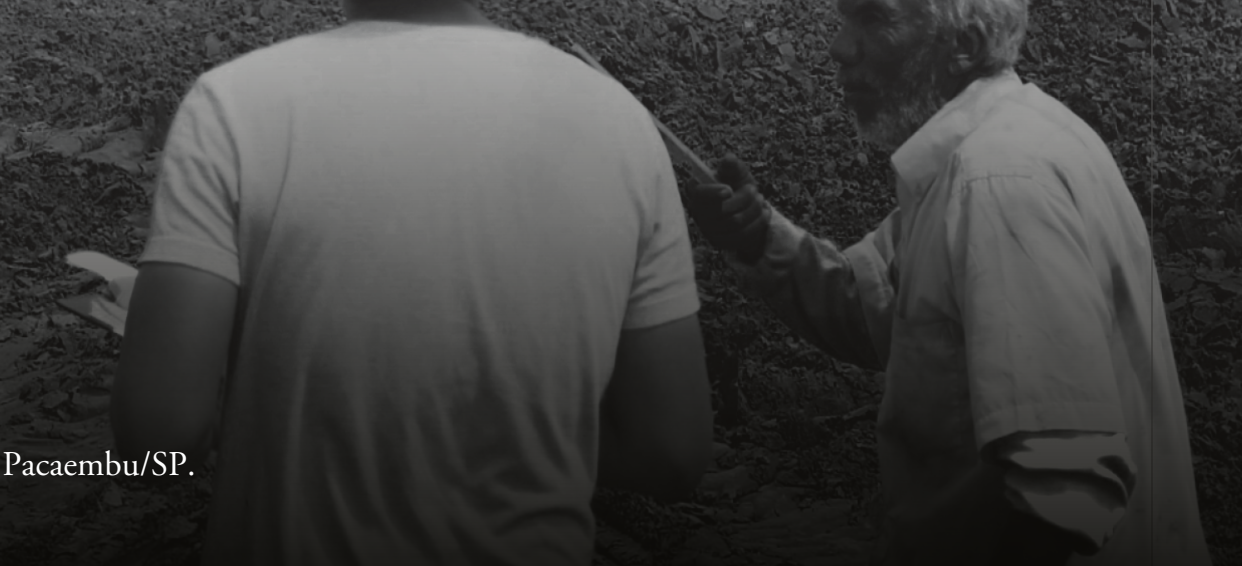

"A participação da população, que na democracia plena que buscamos deveria dar-se por meio da universalizaçáo do acesso à informaçáo e a transferida para o âmbito limitado do instrumental imediato. Por esse procedimento a populaçáo é solicitada a opinar sobre questóes que caberiam aos técnicos resolver [.... Mas enquanto isso permanece 
Nesta terceira parte do trabalho, queremos destacar não apenas o evidente potencial da arquitetura para a qualificaçáo do espaço construído, mas mais importante ainda - ao colocar este campo fora daquele discurso "estético" e formal e extrair o projeto do campo das ideias - queremos aprofundar na compreensão da arquitetura como produto material das relaçóes sociais concretas e sua capacidade de produzir ainda novas relaçóes de produçấo baseadas na própria materialidade de sua produção.

Após as idas aos três assentamentos estudados e ao revisar os desenhos dos projetos, a primeira percepçáo foi a dicotomia entre o projeto e o canteiro. Embora nesse momento eu ainda náo compreendesse a situaçăo, existia a separaçăo entre o "agente" que concebe desconhecido nesse momento e ainda hoje, na maioria dos casos - e quem executa as obras. Historicamente, tem se naturalizado a separação do processo de produção habitacional em dois planos diferenciados náo apenas temporalmente, mas também conceitualmente, ou seja, a partir da ótica comum, o desenho e a execuçáo são considerados unidades que se estruturam por etapas puramente sequenciais e diferentes. Esta delimitação é descrita por Sérgio Ferro $(2006 ; 2015)$ como a simples separação entre proprietários dos meios de produçáo e portadores da força de trabalho - finalmente a subordinaçấo do trabalho ao capital e, portanto, a perda de liberdades.

Para esta pesquisa, o projeto concebido e o projeto executado, como denominaremos a seguir, se configuram como noçôes fundamentais. A primeira está associada às etapas iniciais de desenho e concepçáo, nas quais sáo consideradas as diversas normativas do programa, basicamente na ótica das EOs e das construtoras é fazer o mínimo que a CAIXA pede, sem a participaçáo da comunidade, institucionalizando, assim, o padraáo PMCMV. Já a segunda, com relação ao executado, considera-se a etapa de construção, que implica, neste caso particular, a adaptaçáo dos projetos no sentido de baratear os gastos e ampliar o lucro dos construtores.

Além disso, como descrito previamente, encontramos nos projetos estudados um sujeito - o camponês - que, no seu dia a dia, reproduz relaçôes de produção náo-capitalistas e que, ao mesmo tempo, encontra-se imerso nas contradiçóes e conflitos resultantes da provisão habitacional do PNHR no campo. Como será apresentado nos itens seguintes, estáo se produzindo moradias sem sua participação, ou pelo menos algum tipo de diálogo no processo de concepçáo do projeto de arquitetura, em geral, o envolvimento mais próximo se dá como trabalhadores desvalorizados ou voluntários, aceitando projetos arquitetônicos padronizados e concebidos por "outros", somado ao parâmetros de produtividade impostos pelas construtoras no próprio processo de produçâo em canteiro.

Diante do exposto, cabe perguntar qual tipo de moradia está sendo construída ou quanto vem sendo efetivado o direito à moradia neste contexto de divergência? entre o que é predeterminado pelo PNHR da mesma forma que a casa operária das cidades, caixas de habita conformadas apenas do mínimo -, e o que realmente se faz necessário para a constituição das condiçôes de produção de uma casa camponesa digna. Desta forma, esta parte da tese tem como objetivo demonstrar alguns aspectos dessa negaçáo e da procura de uma moradia de qualidade. 


\section{A casa camponesa brasileira}

42. Vale a pena destacar que

Irea da arquitetura e urbanismo
têm abordado casa e o habitas camponês como tema central rruda (2007), Almeida (2008 Leite (2009), Cerqueira (2009) Tavares (2011), Maia (2011) Barreto (2011), Sertori (2012),
Medeiros (2013), Caraffa (2014), Silva (2014), Lenzi (2017) Cerqueira (2019)

No Brasil, o estudo da habitaçấo do homem simples do campo - aquela casa do trabalhador, sempre afastada da grande propriedade - náo tem hoje muito destaque ${ }^{42}$, na maior parte dos estudos tem priorizado a "casa-grande" dos imponentes engenhos de açúcar, fazendas de café e gado. Segundo Almeida (2008, p.38), isso se dá porque a casa-grande expressa com maior nitidez as características arquitetônicas marcadas pelo tempo, a dinâmica da estratificação social da economia dominante e a memória da cultura herdada dos tempos coloniais. Segundo o mesmo autor, a ausência de informaçôes consistentes sobre a diversidade regional do habitat rural impede uma visão de conjunto da casa camponesa e suas particularidades em todo o território brasileiro.

A habitação camponesa, apesar de não ter muito destaque na literatura e na indústria habitacional no país, merece o reconhecimento em termos técnicos, arquitetônicos e por sua incontestável importância na história da sociedade brasileira. Embora seja compreendida comumente como um utensílio que serve como abrigo elementar, por estar dotada exclusivamente do indispensável, a casa do trabalhador rural é moldada pela vida rural, marcada pela regularidade das práticas regidas pelos ciclos da natureza e pelas tradiçôes que os perpassam, e se apoia na relação dos moradores com a terra e nas relaçôes sociais que dela se originam (LUDWIG, 2006 apud CARVALHO, 2015, p.6). Desta forma, a habitaçáo rural normalmente expōe as seguintes características fundamentais:

a. ao contrário da habitação urbana, a casa camponesa é concebida e materializada num meio ambiente com predomínio da paisagem natural sobre a paisagem construída. Sobre sua forma de organizaçáo no território, Carvalho $(2015$, p.6) destaca que, em grande parte do território brasileiro, nos municípios com pequenos núcleos urbanos e grandes áreas rurais, ainda persiste o tipo de ocupação rarefeita, próprio do espaço rural herdado das nossas raízes coloniais. Neste aspecto, Peres (2003, p.89) ressalta que, a partir dos tipos de organizaçôes rurais historicamente existentes no Brasil hoje, podem-se encontrar novos modelos de agrupação rural, como as vilas rurais e os assentamentos;

b. particularmente, quando a moradia é produzida pelo próprio trabalhador rural, tem a capacidade de adaptar-se ao meio geográfico, à cultura e ao momento em que o homem vive, segundo Costa e Mesquita (1978, p.9). Ao construir a habitaçáo, ele lhe imprime o seu próprio padrão econômico e sua condiçấo sociocultural, utilizando, geralmente, o material fornecido pela natureza que o cerca, de acordo com as técnicas que ele domina.

c. segundo Silva (2014, p.13), enquanto nas áreas urbanas os locais de trabalho e de moradia quase sempre se constituem em espaços físicos distintos, no mundo rural esses espaços se constituem em uma unidade física e espacial única, onde diversas escalas de trabalho, lazer e de interaçáo comunitária e social acontecem. Neste âmbito, Costa e Mesquita, (1978, p.9) complementam que, enquanto a casa urbana se limita à função residencial, a habitação rural também abrange outras funçôes, como a de armazenagem e até mesmo a de beneficiamento da produçáo. Para os pequenos agricultores dos assentamentos rurais, a casa é um elemento indispensável de seu trabalho, pois está fortemente vinculada à terra, na qual se desenvolve sua família; 
d. a habitaçáo do trabalhador rural é um elemento de fixação do homem à terra, sobretudo quando ele contribui com seu próprio esforço e responsabilidade para sua construçâo (PERES, 2003, p.197). Nos assentamentos de reforma agrária, este aspecto se torna ainda mais importante, pois nestes espaços a casa é a marca concreta da ocupação permanente da terra pelo trabalhador rural.

De acordo com o dito anteriormente, é possível definir a habitação rural como um "fenômeno socioespacial" que involucra elementos de ordem biológica, histórica, cultural, econômica, ideológica e política (TENA, 1999). Tradicionalmente, a moradia é o resultado do caráter criador do trabalho humano que, a partir de suas próprias condiçóes, produz objetos que antes náo existiam na natureza. São feitos com os recursos existentes e com conhecimentos populares, quase espontâneos, uma prática herdada e sem nenhuma especializaçáo, razão pela qual a habitação rural é um reflexo da realidade e das características próprias de uma comunidade específica. Por tal razão, é preciso compreender suas expressōes socioculturais como a identidade, o arranjo, o patrimônio, a organizaçấo e integraçáo familiar, os processos míticos e religiosos, a colaboração comunitária e sua relação com a política e o território (MENDES, 2002 apud PERES, 2003).

A respeito da casa rural brasileira, em termos gerais, possui características morfológicas da tradição arquitetônica portuguesa. Contudo, dada sua ampla diversidade geográfica e étnico-cultural, ao longo da sua história, o país desenvolveu uma arquitetura residencial com diferentes características. Sobre este aspecto, Rapoport (1972) considera que as principais explicaçôes sobre as forças que criam a forma da habitaçáo estão relacionadas a aspectos físicos (como o clima e a necessidade de proteção, os materiais e a tecnologia, e o lugar) e aspectos sociais (relativos à economia, defesa e religiáo). $\mathrm{O}$ mesmo autor apresenta a moradia como um fenômeno que representa muito mais do que um abrigo, no qual cada elemento que lhe dá forma é consequência de uma série de fatores socioculturais e ela pode ser modificada segundo condicionantes climáticas, métodos construtivos, materiais disponíveis e tecnologias:

As soluçốes ou adaptaçóes náo têm lugar simplesmente porque sáo possiveis. O marco fisico oferece as possibilidades entre as quais sao feitas
escolhas, através das tradicóes e costumes de uma cultura Ainda quando as possibilidades físicas são numerosas, as escolhas reais podem estar seriamente limitadas pela matriz cultural; esta limitaçáo pode ser o aspecto mais tipico das habitaçóes e assentamentos de uma cultura. (RAPOPORT, 1972, p.66, tradução nossa).

Neste sentido, Peres (2003, p.94), afirma que não é possível definir um único padrão de habitaçáo rural no país, mas sim características e partidos arquitetônicos comuns ou antagônicos que vão sendo apropriados conforme cada realidade. Geralmente, podem-se identificar duas grandes categorias de arquitetura residencial nas áreas rurais, as quais estão diferenciadas por sua estratificação social. Por um lado, aquela residência destinada à classe média e alta, a qual rejeitara os elementos da arquitetura vernacular locais (sobretudo por questão de distinçáo social), adotando, por vezes, algum repertório modernista ou modismos das correntes contemporâneas, apesar do desconforto que causava a seus próprios usuários. (ARAÚJO, DINIZ, 2008). E, por outro, as moradias com uma linguagem própria, que apresentam soluçōes arquitetônicas mais simples, empregadas para atenuar os efeitos do rigor climático. 
Esse tipo de moradias simples é definido por Rapoport (1972) como vernácula e se caracteriza por: a ausência de pretensōes teóricas ou estéticas; considerar o lugar de implantaçăo e o microclima; o respeito ao contexto e consequentemente, ao ambiente total, natural ou "artificial" (fabricado pelo homem); e trabalhar dentro de um padrăo com variaçôes dentro de uma ordem dada. O modelo vernáculo é definido pela colaboraçấo das pessoas ao longo de muitas geraçôes, tanto aqueles que constroem como dos que utilizam os edifícios, chegando, assim, ao que se identifica como tradicional:

A tradição tem a força de uma lei respeitada por todos com o consenso coletivo. Deste modo, aceita-se e obedece porque o respeito à tradiçáo dá lugar a um controle coletivo disciplinador. Este enfoque funciona porque há uma imagem da vida compartilhada por todos, uma hierarquia aceita e, em consequência, um padráo de assentamento aceito. Esta imagem compartilhada e aceita funciona sempre que a tradição esteja viva; se a tradição morre, muda o panorama (RAPOPORT, 1972, p.16, traduçáo nossa).

Uma das principais particularidades da casa rural é a relação com seu entorno. Ela, normalmente, se constitui no centro do conjunto destinado à exploraçáo rural. A partir deste modelo é concebido o espaço exterior da habitaçáo rural como um lugar onde se desenvolve uma ampla gama de atividades e interaçóes sociais. Assim, o sentido de morar no campo não se circunscreve à casa propriamente dita, grande parte das atividades rurais (como trabalho e atividades sociais da família) acontecem no exterior da unidade habitacional.

A varanda, como um dos elementos mais importantes da casa rural, está destinada ao convívio, ao cuidado dos animais e qualquer outra fonte de recursos ou manutenção da família. Além do alpendre nos fundos, que cumpre uma função de serviço e até de espaço para as refeiçôes, em muitas casas está presente a cobertura de telhado prolongada, comumente apoiada sobre pilares e um muro baixo. Este espaço fresco e protegido do sol e da chuva (criando conforto térmico no interior) destaca-se como lugar de reunião, conversas e até mesmo descanso nas redes postas à noite. Ainda hoje, o alpendre é espaço de sociabilidade, importante por seu tamanho, arranjo e frescor.

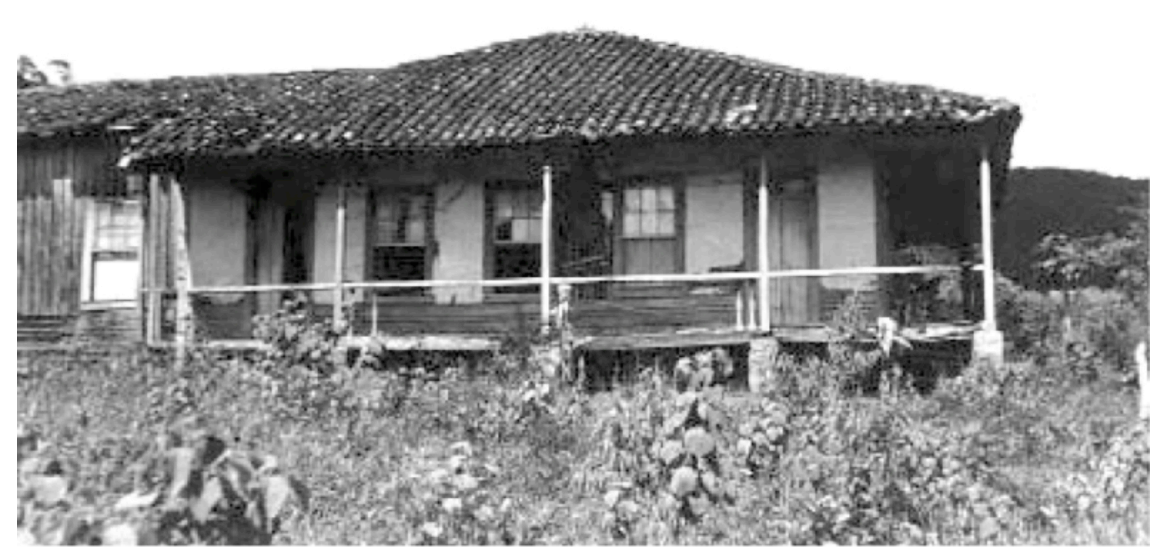

sede da faranda Antiga da (Bofete/ SP. 1948) Fonte: Candido (1998, p. 17) 
fazem parte de um conjunto, com pequenos jardins na frente e uma intensa vida doméstica que se desenvolve na parte dos fundos.

De acordo com Rapoport (1969), nos assentamentos rurais da América Latina, grande parte da vida acontece fora de casa e esta é usada basicamente como um lugar para dormir, armazenar e encerrar animais. Diferente do que acontece nas cidades, onde o interior da habitação é o cenário total para a vida. Existem alguns antecedentes que reforçam a ideia de que a vida rural passa, principalmente, no exterior, ainda mais quando se considera a habitaçáo rural como uma unidade econômica e, assim, a agricultura e outras atividades comerciais sáo fatores que conduzem as atividades para fora.

Já no interior da casa encontramos a cozinha, um dos principais locais de permanência e interação dos moradores na casa rural. Araújo e Diniz (2008, p.49) descrevem este espaço como muito amplo, onde, além de cozinhar e de se realizarem outros trabalhos, também se faziam refeiçôes eventuais. Segundo Lemos (1989), inicialmente, a cozinha ficava próxima aos dormitórios, devido ao costume trazido pelo branco europeu que tinha como centro da casa o fogáo com a finalidade de manter a família aquecida. Já com as novas condiçôes climáticas do território brasileiro, este cômodo passou a ser desligado do núcleo residencial, ou construído do lado de fora, como último ambiente da casa, se abrindo para o quintal, muitas vezes através de um peitoril. No quintal, além de árvores frutíferas e dos animais de criação, havia quartos para depósitos ou despensa.

Keller (1970) descreve este modelo de cozinha, eno nas casas mais simples da região paulista. Este modelo ainda perdura nas áreas rurais em diversas regiōes do Brasil, sendo, assim, uns dos ambientes que mais conserva características do meio rural do país.

É comum essas casas terem um puxado na parede dos fundos, que se um quarto de despejo, onde se colocam instrumentos de trabalho, completa, muitas vezes, as dependências da casa do pequeno trabalhador completa, muitas vezes, as dependencias
rural paulista (KELLR, 1970, p.338).

Localizado estrategicamente ao lado da cozinha, na varanda dos fundos e fora do corpo da casa, encontramos o fogáo de lenha, um elemento que está sempre presente nas casas rurais tradicionais. Segundo Lemos (1989), nas casas remediadas foi comum também a solução que adotava duas cozinhas, uma simples, de pequeno fogáo em puxado ligado á casa e outra maior, a chamada 'cozinha suja', no fundo do quintal, para os cozimentos mais demorados, para derreter toicinho, para clarear o açúcar mascavo, para as tachadas de doces de marmelo e de goiaba. Adicionalmente, são encontradas construçóes anexas no quintal, comumente rústicas, e serviam para guardar utensílios e alimentos de toda espécie. Estas dependências eram destinadas para o trabalho.

A respeito dos materiais e sistemas construtivos, a habitação rural apresenta grande variedade de tipologias construtivas, dada a grande extensáo territorial do país. Segundo Peres (2003, p.93), esses tipos estáo relacionados não apenas com o meio físico, mas também vinculados diretamente às formas regionais de economia e, por vezes, à tradiçấo cultural. Assim, Segundo Keller (1970), para abordar um estudo sobre os materiais e sistemas construtivos da habitaçáo rural, deve se considerar dois tipos as primeiras casas consideradas rurais: a 
casa grande e a senzala. Outra distinçấo ainda pode obedecer ao critério da atividade econômica predominante no meio em que as habitaçôes são construídas.

Olhando para as casas dos pequenos trabalhadores rurais, é sua relação com o meio natural que determina os materiais para sua construçáo. Segundo Peres (2003, p. 95), o barro, a madeira, a palha e outros vegetais vão sendo utilizados na construção da habitação rural. Desta forma, surgem - com a utilização do material eno no próprio meio e correspondendo à posiçăo social do indivíduo - os diferentes tipos de habitaçáo rural no Brasil, cujo fator geográfico complementado pela variedade cultural explica essa imensa gama pelo país.

A arquitetura rural paulista tem como base construtiva a taipa de piláo. Segundo Lemos (1999), a taipa paulista se caracteriza, por nascer de dentro da própria terra, sem providências para combater a umidade natural do solo e a erosão. "Mesmo dentro das valas dos alicerces, os construtores colocavam os pranchóes afastados entre si conforme a espessura da parede desejada e dentro do vão livre era socado o primeiro bloco de terra pilada" (LEMOS, 1999, p.41).

Outra tipologia da arquitetura rural encontrada na regiáo paulista se caracteriza pela utilização do pau-a-pique (taipa de mâo), sistema eno nas casas mais simples. Estas casas săo descritas por Candido (1998, p.45), que ressalta que as habitaçóes rurais eram construídas geralmente com materiais locais e naturais (palha), paredes de pau a pique, varas, tábuas, não barreadas. Nelas, observavam-se o chão de terra batida, os forros de sapé, e as paredes levemente repousando no solo. Também descrita por Keller (1970), que destaca que a casa de pau a pique é erguida sobre o solo e se cobre de telhas portuguesas, as vezes de sapé ou de folhas de palmeira.

\subsection{A moradia rural hoje}

De acordo com Keller (1970), a casa rural é sempre um fator geográfico, exprimindo na sua localizaçáo e no material utilizado as possibilidades do meio natural no modo de construçâa e na disposição das diversas dependências, os recursos técnicos do homem rural, as formas de utilizaçáo do solo por ele praticadas e mais as heranças culturais. Fica evidente que diversos elementos influenciam as tipologias arquitetônicas e construtivas da habitaçăo rural, as condiçôes geográficas, as atividades agrícolas exercidas pelos moradores, a sua estratificação social e nível de vida, assim como as condiçōes culturais.

Da mesma forma que o meio rural suporta uma enorme carga de tradição, é importante compreender também que esses espacos não são estáticos, particularmente hoje com o acesso da população rural a bens e serviços produzidos na cidade e da apropriaçáo de alguns aspectos da cultura urbana. Com o passar do tempo, as casas rurais foram se transformando. Fenômeno ocasionado pelo fluxo (nos dois sentidos) da força produtiva do campo-cidade, surgindo, desta forma, uma aproximação dos modos de vida desses territórios, situaçáo que se reflete no padráo de moradia tradicional.

Em meados do século passado, no estudo sobre os caipiras do interior de São Paulo, Antonio Candido (1998) analisa as mudanças que a moradia sofre quando os bens de consumo alcançam as áreas rurais e modificam vários aspectos da vida do caipira. Segundo o autor, o modo 
de vida caipira passou por uma redefiniçáo nos seus vínculos de dependência, que incorporaram a órbita da fazenda e das povoaçóes, afastando-se relativamente das estruturas tradicionais típicas. Diante desta realidade de transformaçóes, o autor classifica estes indivíduos e sua reaçâo à mudança: o caipira que procura se adaptar ao máximo às novas condiçốes; o camponês que se apega à vida tradicional, mas procurando vincular suas tradiçôes com as exigências presentes; e o que é totalmente incapaz de ajustar-se às duas condiçóes anteriores.

Apesar destas transformaçóes, percebe-se a persistência de características e formas de morar que permanecem no decorrer dos anos. Conforme Rapoport (1969), algumas formas construtivas são aceitas e resistem fortemente às mudanças, devido à importância dada às tradiçôes.

Um dos aspectos da moradia rural que ainda permanece com força na atualidade está relacionado, principalmente, ao estilo de vida de seus habitantes, refletida na configuraçáo espacial da casa. Desta forma, a intensa vida social e as atividades cotidianas desenvolvidas pela família dáo forma aos ambientes. Este aspecto é estudado por Ferreira $(2007)^{43}$, pesquisa na qual sâo refletidas as percepçóes dos moradores do acampamento rural Terra Livre quanto ao grau de uso dos espaços e às possíveis melhorias da casa.

Segundo o mesmo autor, a presença dos moradores em determinados cômodos na execuçấo de diferentes tarefas modela os diferentes ambientes da casa. Comumente, encontramos marcadas posiçóes de gênero e hierarquia existentes nas famílias tradicionais rurais, refletindo os hábitos culturais e as estratégias e divisōes do trabalho familiar. Por exemplo, enquanto os homens desenvolvem atividades, principalmente, as ligadas à produção e criação, as mulheres, exercem tarefas de tipo doméstico, relacionadas com o cuidado da casa (principalmente da cozinha), da horta e dos animais (FERREIRA, 2007, p.64). Desta forma, ambientes como a cozinha e a varanda se configuram, no meio rural, como espaços de grande importância para o desenvolvimento e conforto dos seus moradores. Por um lado, a cozinha, além de ser um espaço de trabalho doméstico, serve para a socializaçáo e convívio. Por outro, a varanda, por ser um ambiente mais amplo e mais ventilado, proporciona melhores condiçóes para o descanso das duras jornadas e, inclusive, pode ser usado para outras tarefas secundárias.

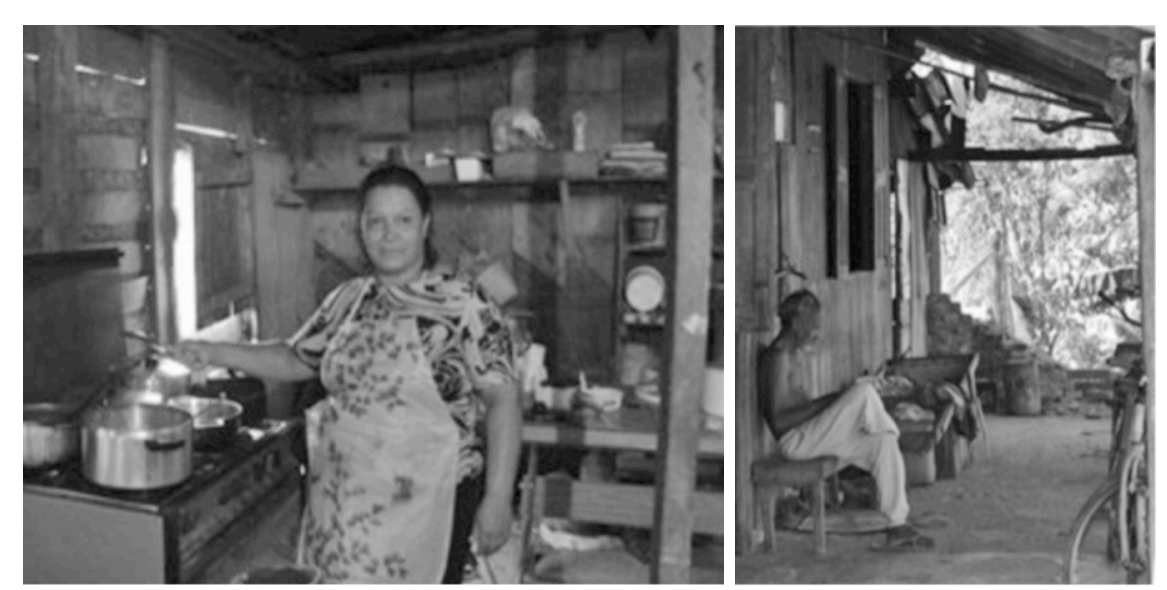

Figura 49. Cozinha e varanda de Fonte: Ferreira (2007); fotos
Thiago Ferreira

A respeito das atuais características físicas, pode-se perceber a influência dos padróes urbanos nas moradias rurais de hoje. Muitas edificaçōes, novas ou reformadas, expressam mudanças nos tipos de materiais que as compóem, sendo substituídos os locais utilizados comumente nas moradias camponesas, por materiais de acabamento industrializados, 
principalmente nos revestimentos (como pisos de cerâmica, azulejos na cozinha e no banheiro), janelas de vidro com esquadrias de alumínio e laje maciça ou forro de PVC (figura 50).

Figura 50. Banheiro localizado na parte externa (esquerda)
interna direita) da casa

Fonte: Guimarāes et al. (2013, p

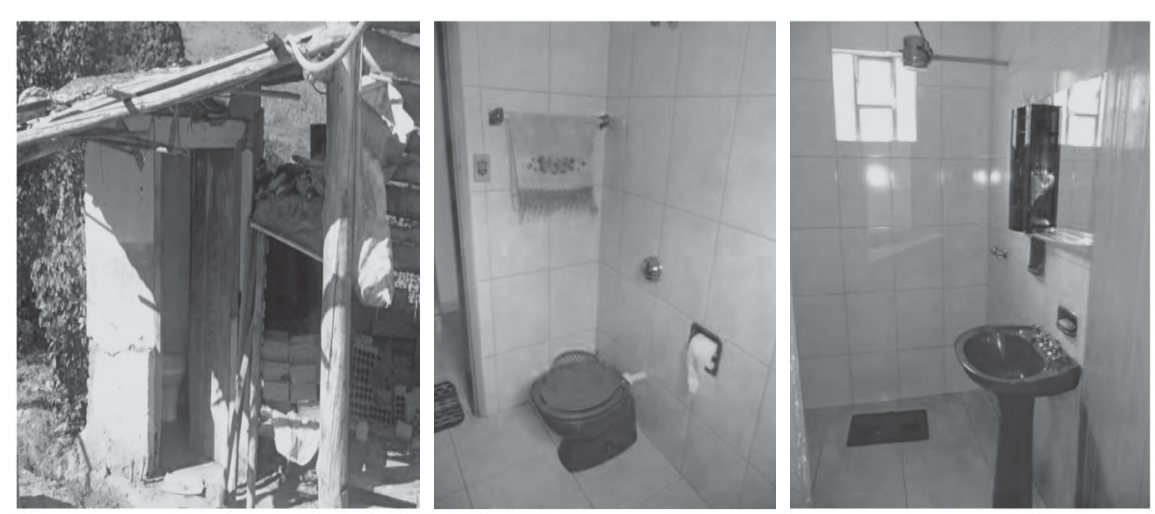

Esta situação é estudada na pesquisa realizada por Guimarães et al. (2013), na qual demonstra que, além da facilidade de aquisição destes materiais (pelo preço e pela disponibilidade), há indícios de influência dos padrōes urbanos nas moradias rurais atuais, tanto em relação ao acesso à infraestrutura como nos aspectos ligados às alteraçóes no interior da casa. Há diversos interesses envolvidos na indústria da construçáo e o pouco interesse das comunidades em continuar construindo com materiais tradicionais, desconhecendo estas técnicas e materiais, muitos dos quais, com o passar do tempo, acabam sendo esquecidos.

Isso faz com que a implementação destes tipos de tecnologias em projetos de interesse social nas áreas rurais - apesar de possibilitar a redução de custos, baixo consumo energético e maior conforto ambiental - seja cada vez mais complexo, devido à falta de domínio tecnológico das comunidades e ao pouco interesse para acompanhamento técnico das entidades encarregadas.

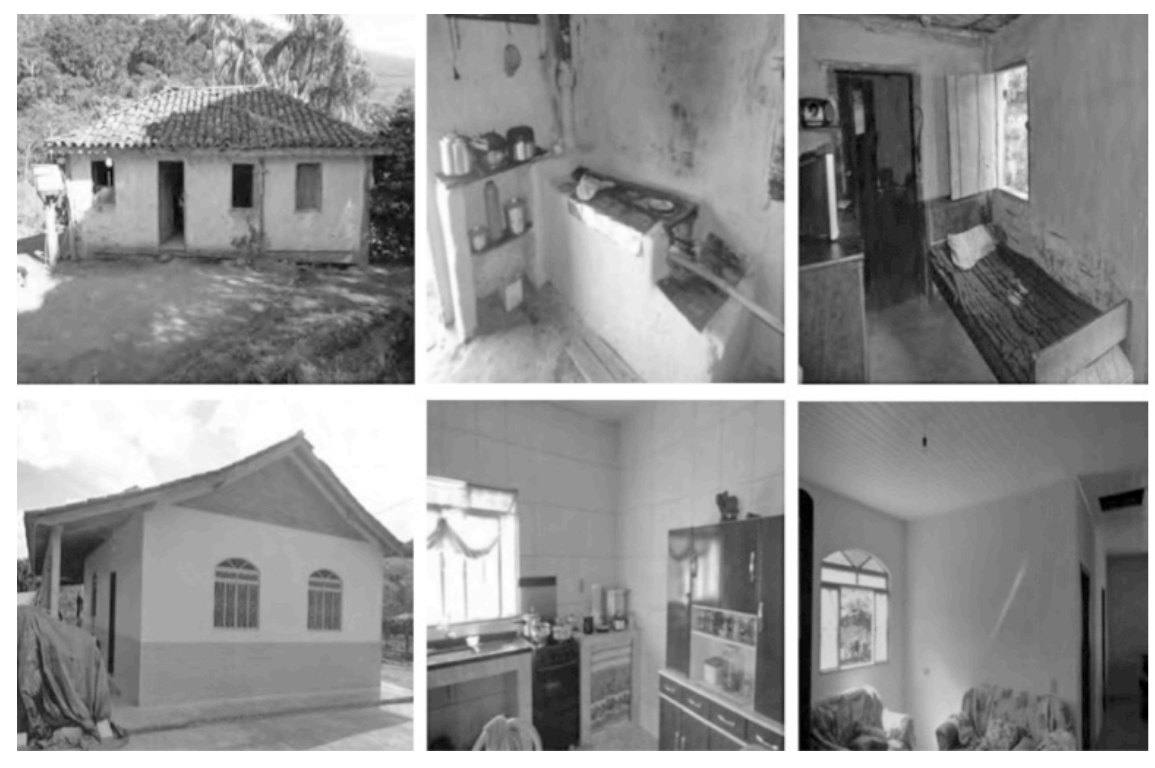

Figura 51. Mudanças no exterior cozinha na moradia rural. Fonte: Guimarăes et al. (2013, p

Após o reconhecimento das características que distinguem a moradia do trabalhador rural brasileiro, cabe salientar que o camponês năo está totalmente isolado dos desejos dos bens de consumo que o mercado oferece, fato que se percebe na aquisiçáo de produtos eletroeletrônicos e mobiliários. Não obstante este fato torna-se ainda mais expressivo nas moradias, nas quais, com maior frequência, estão sendo utilizados materiais industrializados e padrōes habitacionais diferentes dos tradicionais. Porém, apesar destas transformaçóes, percebem-se aspectos fundamentais que ainda persistem e se mantêm no tempo, principalmente aqueles relacionados com o desenvolvimento de suas atividades diárias. Desta forma, cabe aos agentes envolvidos e técnicos responsáveis pelo desenvolvimento dos projetos habitacionais 
reconhecer, interpretar e conciliar estes aspectos junto com os moradores.

\section{Projeto concebido: inadequação do}

\section{padrão PMCMV}

De acordo com Lefebvre (1978), o habitat é o espaço em que o indivíduo habita, sem restriçōes físicas ou construídas, extrapolando, desse modo, o entendimento da moradia como apenas um invólucro físico e sim como tudo aquilo que circunscreve a vida do ser humano. Neste sentido, Heidegger (1990) define o habitar como aquilo que faz parte do homem, um âmbito que ultrapassa qualquer tipo de construçōes, são os lugares que oferecem ao homem um abrigo mesmo não sendo ali a sua habitação -, e também os lugares aos quais dedica tempo, atençăo e cuidados, ou seja, habitar e construir encontram-se, assim, numa relação de meios e fins. Construir já é em si mesmo habitar.

Segundo Lawrence (1987; 1990), a habitaçáo representa muito mais do que um simples núcleo territorial, mais do que uma ordenaçấo espacial. Constitui-se como uma entidade complexa tanto no âmbito teórico e conceitual, como no campo prático. Define e é definida por conjuntos de fatores arquitetônicos, culturais, econômicos, sociodemográficos, psicológicos e políticos que mudam durante o curso do tempo. Em concordância, Villa e Ornstein $(2013$, p.15) consideram que a habitação é muito mais do que o objeto edificado, expandindo-se ao entorno imediato da moradia, revestindo-se de características subjetivas inerentes à relação que estabelece entre o(s) morador(es) e o ambiente sociofísico que o(s) recebe. Na visão de Lawrence (1990, p.124), no interior das moradias há a conformação de dimensôes que se integram, proporcionando uma dinâmica própria no modo de viver e conviver dos que nelas habitam.

Do ponto de vista cultural, a casa reflete o estilo de vida dos moradores através de regras expressas nos rituais domésticos e sociais. Regras explícitas ou tácitas, ancoradas em valores impostos e/ou compartilhados. Para Lawrence (1990), a casa é também uma categoria reveladora da linguagem, pois demarca e comunica relaçoes do tipo público e privado, sujo/limpo, frente/fundos.

Como base para o entendimento da habitaçáo no meio rural, pode-se dizer que a mesma deve ser concebida em relaçáo à área na qual está inserida. Isto é, sua relação específica com o habitat, particularmente, no seu contato privilegiado com a terra, o camponês constrói paisagens produtivas. Isto quer dizer, nas palavras do Heidegger (1990), a noção de habitar, associada ao modo de vida camponês, nấo se relaciona apenas ao ato de edificar construçóes, aedificare, um outro modo de construir como ato de cultivar, em latim, colere, está contido no sentido próprio de bauen, ou seja, no construir.

No sentido de habitar, ou seja, no sentido de ser e estar sobre a terra, construir permanece, para a experiência cotidiana do homen, aquilo que

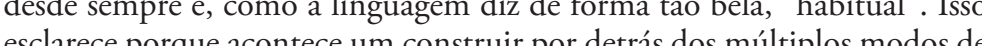
esclarece porque acontece um construir por detrás dos múltiplos modos de
habitar, por detrás das atividades de cultivo e edificacáa. Essas atividades acabam apropriando-se com exclusividade do termo bauen (construir) e
com isso da propria coisa nele designada. (HEIDEGGER, 2002, p. 127)

A forma como o habitat foi pensado e erigido está relacionado à experiência e à prática cotidiana dos lugares do seu construtor. Desta 
forma, como expóe Peres (2003, p.5), há que levar em conta que a habitaçấo reflete o modo de vida da população e a contínua construçăo do espaço periférico, uma vez que esses aspectos exercem influência direta sobre a composiçáo da família, o trabalho, a organização comunitária, a cultura construtiva e as condiçōes do meio ambiente. Segundo Villa e Ornstein (2013, p.15), a habitaçáo como objeto de estudo, deve ser compreendida como uma entidade que conecta pessoas (indivíduos e geraçoes), tempos (passado e futuro dos ocupantes) e vários elementos do contexto socioambiental em que está inserida sendo considerada uma das fontes que contribuem para a definiçáo da identidade do indivíduo e da família.

Assim, a moradia camponesa, ao contrário do que se pensa comumente, é uma entidade complexa, que se materializa no contexto dos seus moradores, capazes de se moldar eles mesmos e seu próprio espaço, cujas características correspondem a uma expressão cultural específica, em que cada formação social assume formas particulares em termos de ocupaçáa, apropriaçáo, e representaçáa do espaço e território.

No entanto, apesar de alguns resultados na redução do déficit habitacional, após vários anos do início do Programa Nacional de Habitaçáo Rural (PNHR), evidenciam-se soluçôes arquitetônicas convencionais que se repetem no Brasil inteiro, sem uma adaptaçáo às necessidades regionais da população. Também, segundo Carvalho et al. (2015, p.12), por desconsideraçấo ou desconhecimento do modo de vida rural, reproduzindo o mesmo modelo de moradia adotado pelo PMCMV nas áreas urbanas.
Diante deste panorama, o tema abordado nesta parte relaciona-se à inadequação dos projetos habitacionais cerqPNHR, focando nas especificaçōes mínimas previstas para as moradias rurais. Por fim, é desenvolvida uma análise dos projetos arquitetônicos, na qual serão discutidos trabalhos sobre avaliaçáo habitacional de Marques (2012) e Hillier, (2007), que tratam sobre organizaçăo espacial; Boueri, Pedro e Scoaris (2012) do Laboratório Nacional de Engenharia Civil de Lisboa - LNEC, sobre adequaçáo do espaço da unidade habitacional e; autores como Till e Schneider (2005), Amorim et al. (2015) e Bastos (2014), sobre flexibilidade, entre outros, contribuindo, assim, para a discussão sobre a compatibilidade da habitação produzida pelo atual programa habitacional nos assentamentos de reforma agrária.

De acordo com as especificaçóes mínimas do Programa Minha Casa Minha Vida / PNHR (2012), a casa rural deve ter área mínima útil de $36 \mathrm{~m}^{2}$, que deverá estar sujeita a uma soluçáo de ampliaçăo, com o objetivo de se adaptar às necessidades e características de cada núcleo familiar. Dentro desta área mínima, a casa deve conter os seguintes cômodos: sala de estar e refeiçôes conjugadas, dois dormitórios (um

\subsection{OPNHR - especificaçóes minimas}

para o casal e outro para duas pessoas), cozinha, área de serviço coberta (externa), circulação e banheiro. Para o dimensionamento destes cômodos, as especificaçóes do PNHR definem duas condiçóes: de um lado, a largura mínima da cozinha $(1,80 \mathrm{~m})$, do banheiro $(1,50 \mathrm{~m})$ e da sala $(2,40 \mathrm{~m})$, e de outro, para o resto dos cômodos, definem a quantidade e as dimensóes do mobiliário mínimo. De acordo com Carvalho, Paula e Pereira $(2015$, p.7), esta determinaçấo tem por 
objetivo dar liberdade aos projetistas para dimensionar os ambientes de acordo com o mobiliário previsto, evitando conflitos com legislaçóes estaduais ou municipais que versam sobre dimensôes mínimas dos ambientes. Também encontramos as dimensōes mínimas do pé direito, o qual deve ser de 2,30 m nos banheiros e 2,50 m nos demais cômodos, dimensóes comumente estabelecidas para a casa urbana do PMCMV.

Quanto aos mobiliários mínimos, a sala de estar (conjugada com sala de refeiçóes) deve conter sofá com número de assentos igual ao número de leitos, mesa para 04 pessoas e uma estante ou armário para TV. A quantidade mínima de equipamentos para a cozinha restringe-se a uma pia sobre bancada de $1,20 \mathrm{~m} \times 0,50 \mathrm{~m}$; fogáo de $0,55 \mathrm{~m} \mathrm{x} \mathrm{0,60} \mathrm{m} \mathrm{e}$ geladeira de $0,70 \mathrm{~m} \times 0,70 \mathrm{~m}$. Fica claro como o espaço para refeiçóes encontra-se no interior da casa, conjugado com sala, ao contrário do que acontece no meio rural, onde as refeiçóes, normalmente, são feitas na cozinha ou na varanda dos fundos. Já o dormitório de solteiro deve conter como mobiliário mínimo 02 camas de $0,80 \mathrm{~m} \mathrm{x} \mathrm{1,90} \mathrm{m} \mathrm{(com}$ uma circulaçáo mínima entre as camas de $0,80 \mathrm{~m}$ ), um criado-mudo $(0,50 \mathrm{~m} \times 0,50 \mathrm{~m})$ e um guarda-roupa pequeno $(1,50 \mathrm{~m} \times 0,50 \mathrm{~m})$. Para o dormitório de casal é definido o mesmo mobiliário, mudando somente a cama de casal de $1,40 \mathrm{~m} \times 1,90 \mathrm{~m}$.

À área de serviço prevista no PNHR é incorporada a máquina de lavar roupas $(0,60 \mathrm{~m} \times 0,65 \mathrm{~m})$ e um tanque $(0,52 \mathrm{~m} \times 0,53 \mathrm{~m})$. Segundo Carvalho, Paula e Pereira (2015, p.8), esta área de serviço prevista no PNHR tem conotaçáo tipicamente urbana. Inclusive a própria denominaçáo "área de serviço" náo é própria do meio rural, onde as tarefas de lavar e passar roupas ocorrem na "varanda" aos fundos da

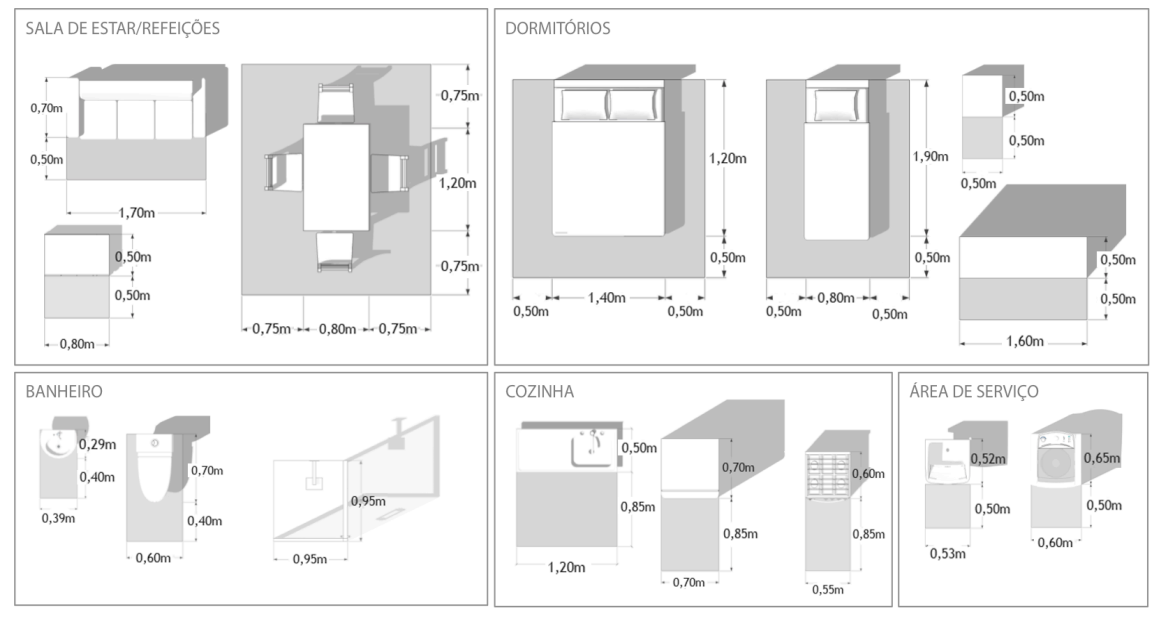

Figura 52. Especificaçóes mínimas
para mobiliário - PNHR/PMCMV

Fonte: Elaboracăáo do autor.

casa.

A acessibilidade, tema que passou a ser uma preocupação a partir de uma reformulaçáo nas especificaçôes na Fase 2 do PMCMV, está presente em vários cômodos da casa. Assim, no banheiro teve-se o cuidado de exigir a previsão de área para pessoas em cadeiras de rodas ou mobilidade reduzida fazerem a transferência ao vaso sanitário e ao box. É uma exigência também o espaço livre de obstáculos em frente às portas de no mínimo $1,20 \mathrm{~m}$, além de manter em todos os cômodos o módulo de manobra para cadeiras de rodas sem deslocamento para rotaçăo de $180^{\circ}(1,20 \mathrm{~m} \times 1,50 \mathrm{~m})$, definido pela NBR9050/04.

Além disso, sobre os sistemas construtivos, o PNHR recomenda-se que a casa deva ter cobertura em telha cerâmica, sobre estrutura de madeira ou metálica, com beirais de no mínimo $60 \mathrm{~cm}$. Admitindo-se telha em fibrocimento, com espessura mínima de $6 \mathrm{~mm}$, nas regiôes CentroOeste, Sul e Sudeste, porém, é obrigatório o uso de forro em madeira, 
$O$ revestimento interno deve ser feito em pintura sobre reboco ou gesso e o externo deve ser texturizado ou com pintura acrílica sobre reboco, Para o revestimento das áreas molhadas (banheiro, cozinha e área de serviço), deve-se adotar azulejo com altura mínima de 1,50 m em todas as paredes. Para a área interna da casa, deve-se adotar pisos cerâmicos, com desnível máximo de $15 \mathrm{~mm}$. Cabe ressaltar que, quando é utilizado algum tipo de tecnologia inovadora, homologada pelo SINAT, devemse seguir suas diretrizes.

Sobre as portas e janelas, são permitidas em madeira ou metálicas, com vão de $1,20 \mathrm{~m}^{2}$ nos quartos e $1.50 \mathrm{~m}^{2}$ na sala, sendo admissível uma variaçăo de até 5\%. Quanto às instalaçôes elétricas e hidrossanitárias o programa exige:

vários pontos de tomadas elétricas ( 2 na sala, 4 na cozinha, 1 na área de serviço, 2 em cada dormitório, 1 no banheiro, 1 ao lado do tanque e mais 1 tomada para chuveiro elétrico), 1 ponto de antena de TV na sala e um ponto de iluminação em cada ambiente;

- prever circuitos independentes para chuveiro, tomadas e iluminação;

prever reservatório de água de capacidade mínima de 500 litros ou maior quando exigido;

- instalaçáo de aquecimento solar para a água do chuveiro e a construção de cisterna pluvial são opcionais e prever solução para máquina de lavar roupas (ponto elétrico, hidráulico e de to ao esgotamento sanitário, admite-se o uso de fossa - séptica e sumidouro.

No exterior da casa, recomenda-se a construção de uma calçada em concreto com largura mínima de $0,50 \mathrm{~m}$ ao redor da edificaçáo e de no mínim• $1,20 \mathrm{~m}$ em frente ao tanque e à porta da cozinha, como elemento de proteçáo da alvenaria externa. Já quanto à infraestrutura externa, exige-se que o sistema de abastecimento de água seja adequado às condiçóes locais e que as vias de acesso estejam em condiçóes de tráfego de veículos.

Finalmente, com o objetivo de dar ao profissional responsável pela elaboração do projeto arquitetônico a liberdade de adaptar os projetos às particularidades de cada regiáo, o programa recomenda que os projetos arquitetônicos devam apresentar compatibilidade com as características regionais, locais, climáticas e culturais da comunidade, mediante compensaçáo na melhoria da unidade habitacional e comunicaçáo à Secretaria Nacional de Habitação (SNH) do Ministério das Cidades.

Assim, de acordo com o anterior, observa-se que nas especificaçóes mínimas do PMCMV/PNHR são apresentadas alternativas tipológicas e construtivas que impóem fortes limitaçóes para implementar soluçóes autóctones, que representam a cultura local e sua arquitetura vernacular, soluçôes mais adequadas às particularidades de cada região, pois incorporam o saber local e suas tradiçóes.

A organizaçáo espacial de uma habitação camponesa possui várias 
44. Foram consideradas quatro projetos habitacionais desenvolvidos pelo Grupo HABIS. Em 2002, HABIS iniciou sua experiência e sentamento Pirituba II. Neste projeto, foram construídas 4 unidades habitacionais, com o das famílias nas etapas trojeto e construçáa, sendo tipologia 3 quartos, com banheiro
fora (3QBF). Já em 2006, o HABIS assumiu a coordenaçáo do projett
habitacional no assentamento rura Azul/SP, onde foram construídas 77 unidades habitacionais con INcursos do convênio CAIXA
INCRA, com a inclusão dos assentados na construçắo e eestáa
da obra. Neste projeto, foram struídas as seguintes tipologias alternativas (3 quartos $-3 \mathrm{QAA})$.
and particularidades, especialmente se considerarmos a habitaçáo rural como uma unidade econômica. Em outras palavras, os níveis de hierarquia e proporção entre as áreas dos cômodos são determinados pelas atividades agrícola, de produçáo e comercializaçáo que se dáo neste local. Com o objetivo de compreender este aspecto nos projetos

\subsection{Avaliaçáo do projeto concebido}

estudados, são comparadas as métricas destas unidades habitacionais com quatro tipologias de referência (tabela 10) com o objetivo de encontrar alguns pontos de contraste. Estes projetos foram desenvolvidos pelo grupo de pesquisa HABIS na modalidade de assessoria técnica ao MST nos assentamentos Pirituba II e Sepé Tiaraju4 ${ }^{44}$. Estes exemplos foram escolhidos a partir de dois critérios: a) estes projetos se destacam por conter características arquitetônicas e arranjos comparáveis com os estudos de caso desta pesquisa e b) por serem considerados bons exemplos em termos de arranjos, dimensóes e qualidade espacial, principalmente por se tratarem de projetos concebidos a partir da participaçáo ativa da comunidade envolvida e do diálogo com os projetistas.

Conforme o exposto na tabela 10, podemos constatar que a cozinha e a varanda se constituem como elementos cruciais desta análise, uma vez que em términos de área útil se apresentam como componentes pouco privilegiados nos projetos dos contratos estudados. Em primeiro lugar, as mediçóes mostram que a área destinada para cozinha sempre é meno que a área da sala de estar e quartos, enquanto nos projetos de
Tabela 10. Comparativo de áreas de referência em $\mathrm{m}^{2}$.

\begin{tabular}{|c|c|c|c|c|c|c|c|c|c|c|}
\hline \multirow{2}{*}{\multicolumn{2}{|c|}{ Contratos }} & \multicolumn{9}{|c|}{ Áreas dos Cômodos (m²) } \\
\hline & & Área Útil & Sala & Cozinha & No. & Quartos & Banheiro & Circulação & Serviço & Varanda \\
\hline \multirow{2}{*}{$\begin{array}{l}\text { Florestan } \\
\text { Fernandes }\end{array}$} & FF120 & 56.57 & 12.74 & 12.08 & 3 & 24.05 & 4.33 & 1.07 & 2.3 & \\
\hline & $\overline{F F 44}$ & 52.03 & 12.61 & 5.2 & 2 & 16.44 & 4.33 & 1.07 & 5.72 & 6.66 \\
\hline \multirow{2}{*}{ Boa Esperança } & BE26 & 54.13 & 9.58 & 7.85 & 3 & 24.14 & 4.2 & 1.5 & 6.86 & - \\
\hline & $\mathrm{DC} 27$ & 48.94 & 8.25 & 5.69 & 3 & 23.85 & 4.08 & 1.74 & 5.33 & - \\
\hline \multirow[t]{2}{*}{ Dona Carmem } & $\mathrm{DC} 10 \mathrm{~T} 3$ & 56.21 & 10.46 & 10.37 & 2 & 18.68 & 5 & - & 2.25 & 9.45 \\
\hline & DC10 T5 & 46.79 & 11.85 & 7.86 & 2 & 21.45 & 4.53 & - & 1.1 & 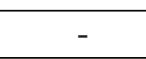 \\
\hline \multicolumn{11}{|c|}{ Projetos de Referência } \\
\hline \multirow[t]{2}{*}{ Pirituba II } & 3QBF & 66.81 & 8.68 & 17.32 & 3 & 26.04 & 2.62 & - & - & 12.15 \\
\hline & $2 Q \mathrm{QC}$ & 52.02 & 8.67 & $21,93^{*}$ & 2 & 17.34 & 2.88 & 1.2 & $\pi$ & 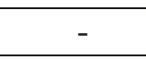 \\
\hline \multirow[t]{2}{*}{ Sepé Tiaraju } & $3 Q \mathrm{QC}$ & 53.16 & 8.84 & 13.6 & 3 & 26.52 & 2.7 & 1.5 & - & 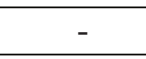 \\
\hline & 3QA & 64.5 & 11.37 & 11.38 & 3 & 23.4 & 2.81 & 5.12 & - & 10.5 \\
\hline
\end{tabular}

referência, esta situaçáo é diferente, pois é possível observar uma maior valorizaçấo destes ambientes, não se restringindo apenas ao preparo dos alimentos, mas também por se configurarem enquanto espaços de grande importância para o desenvolvimento dos moradores nas áreas rurais, sobretudo por ser uma área que deve comportar atividades de apoio à produção e sociabilidade.

A respeito da dimensão da varanda, encontramos uma diferença importante dos projetos de referência com os estudos de caso, nos quais este espaço se configura apenas como um beiral de acesso à casa - ou mesmo nem é considerado. Somente no projeto DC-10 (tipologia 3) esta área foi valorizada, com $17 \%$ do espaço total da casa. Vale a pena destacar a importância deste cômodo no cotidiano da família "na area da cozinha é somada a ea complementar destinada à partir de informaçóes fornecidas
pelas construtoras). Fonte: Grupo Habis, 2018 (a 
camponesa, que enfaticamente ressalta a varanda como fundamental na configuração das suas casas.

Outro cômodo que ganha destaque é o quarto, pois, apesar de se configurar num espaço secundário nas casas rurais, já que é usado apenas para o descanso noturno, as mediçôes mostram que, por exemplo, no projeto DC-27 ocupa quase a metade da área útil, com $48,73 \%$ da área total da casa, segundo a figura 53.

Outro aspecto para ser destacado está relacionado com o tema da acessibilidade, que passou a ser uma preocupaçáo a partir de uma reformulação nas especificaçôes técnicas previstas para a segunda fase do PMCMV. Nos casos estudados, teve-se o cuidado de exigir a previsáo de área para pessoas em cadeiras de rodas ou mobilidade reduzida fazerem a transferência ao vaso sanitário e à área do chuveiro.

Figura 53. Comparativo (em \%) quatro projetos referência. Fonte: Grupo Habis, 2018 (a partir
de informacōes fornecidas pelas construtoras)

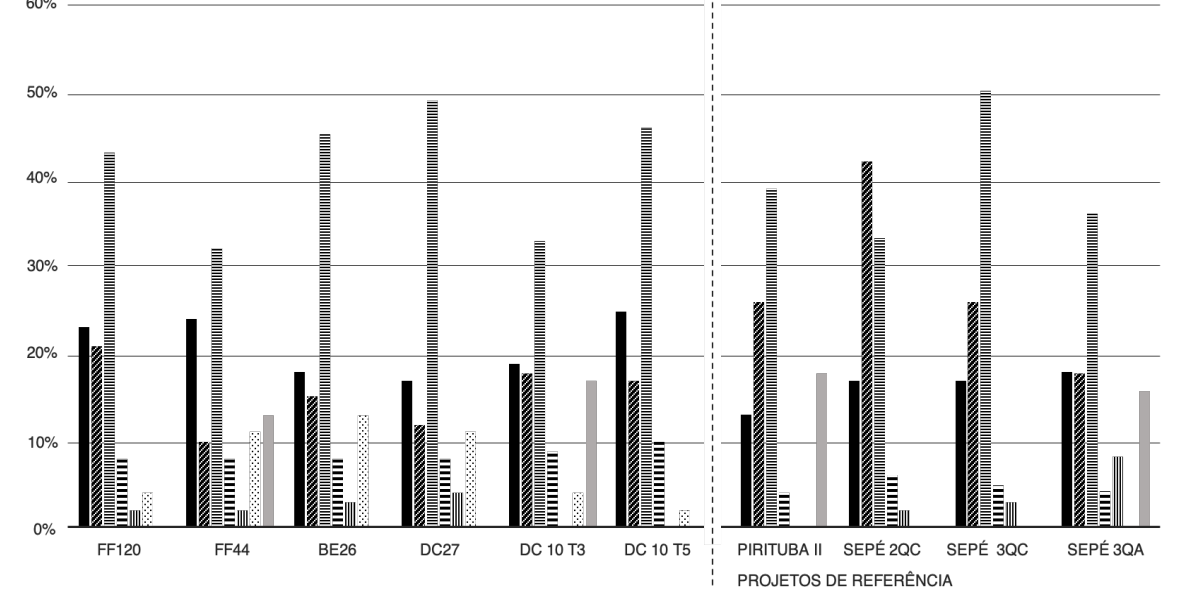

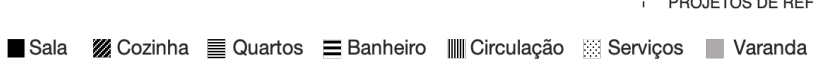

Nos casos estudados este aspecto corresponde entre 8\% e 10\% da área total da unidade, enquanto, nos projetos referência, as porcentagens são menores, variando entre $4 \%$ e $6 \%$ (figura 53).

Outra análise empreendida se relaciona com a organização espacial das unidades habitacionais. Este modelo de análise de permeabilidade dos espaços proposto por Marques (2012) e baseado na publicação do Bill Hillier (Space is The Machine - Space Sintax), revela, de forma esquemática, o arranjo e a relação entre os cômodos através dos eixos estruturantes das unidades que, segundo o autor, funciona como uma radiografia que evita a subjetividade do estudo.

Para esta análise, interessa a construçấo dos gráficos justificados, que consiste na transformação da planta em um formato abstrato, representado por um ponto em cada cômodo. Em seguida, os pontos dos cômodos vizinhos (os que estejam comunicados) sáo conectados com uma linha, selecionando o nó que será a raiz do gráfico. Os níveis de profundidade de cada raiz sáo lidos de maneira vertical (de baixo para cima).

A partir da aplicação desta metodologia (figura 54), foi possível identificar que o arranjo dos cômodos das unidades é relativamente conservador e de características urbanas. As imagens abaixo evidenciam que, em primeiro lugar, a sala se configura como o centro da estrutura organizacional, uma vez que o acesso à casa é concebido a partir deste cômodo, acesso que se dá na fachada principal da unidade e, em segundo lugar, esta análise revelou que a distribuição dos outros cômodos é feita a partir da sala. Esta situação fica mais evidente se compararmos com a organização da tipologia de referência $3 \mathrm{QBF}$ 
Pirituba II, na qual a sala é secundária, dando maior valor à cozinha e à varanda. Nesta tipologia, a cozinha é pensada como o maior espaço de permanência da casa que, somada somado ao da sala como dois eixos de distribuiçăo da circulação, promove uma maior permeabilidade e amplia as possibilidades de expansão dos cômodos circundantes.

Portanto, a valorização de um espaço não está dada apenas pelas suas dimensóes (como comprovado nas análises métricas). Queremos evidenciar também a relevância da localizaçấo destes cômodos no arranjo espacial da casa. Este é o caso particular da cozinha e da varanda, fundamentais no funcionamento da casa camponesa. Carvalho et al. (2015) destaca que a cozinha e a varanda sáo os ambientes que conservam mais características dos costumes tradicionais do meio rural, os quais, sempre comunicados diretamente, são destinados às atividades de serviço e "por excelência, o local de permanência dos moradores e o 'centro interacional' na casa dos pequenos produtores", diferente do que acontece nas casas da cidade e, como visto nos projetos dos contratos estudados, nas habitacôes financiadas pelo PNHR, cujas varandas se voltam para a rua $e$ as cozinhas encontram-se no interior do corpo da casa.

A respeito da localizaçáo e da orientaçáo da varanda, os aspectos relativos à insolação e à ventilação terminam sendo ignorados, trazendo como consequência a perda de sua funcionalidade de sombreamento e até mesmo prejudicando a ventilação interna da moradia. Quanto à exposição solar das unidades dos lotes 153, 158 e 172 do assentamento Dona Carmem, localizadas na zona bioclimática $4^{45}$, apresentam
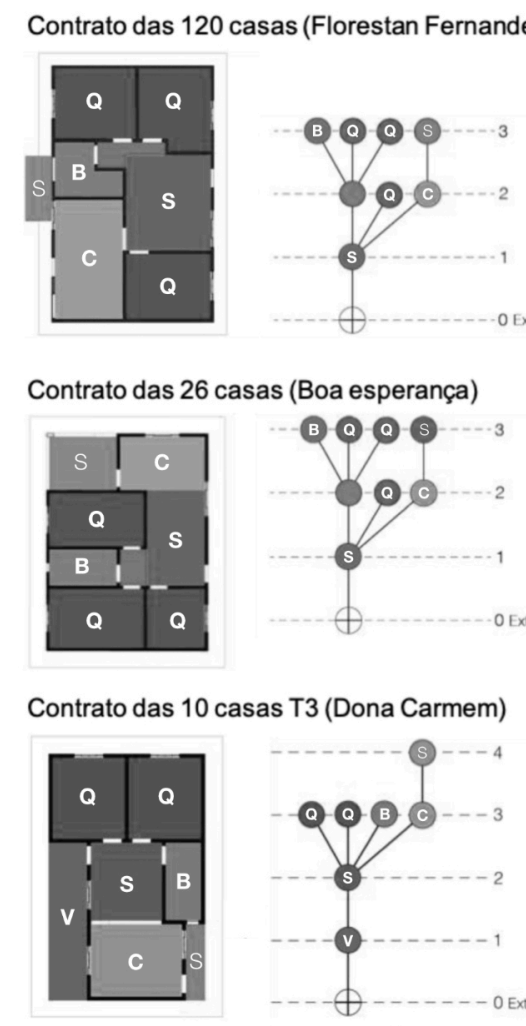

OSala @cozinha ๑ Quartos @Ban

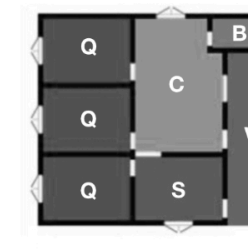

Ocirculaçăo

sombreamento excessivo nas paredes externas voltadas para o norte, o que causa desconforto devido ao frio no inverno

Também identificamos nos projetos estudados uma evidente rigidez (em relaçáo às possibilidades de ampliaçăo ou reforma) na organizaçăo da planta arquitetônica. Essa deficiência seria facilmente solucionada ou atenuada por meio de estratégias de adaptaçáo no uso das unidades e a inserçáo de novos usos e programas, compreendendo que a evolução da edificaçáo estaria aberta a possibilidades de extensão para além dos
Figura 54. Comparativo (planta
e esquema de permeabilidade) da organizaçăa espacial das unidades estudadas e un

tipologia de referência

Fonte: Grupo Habis, 2018 (a partir de informaçōe
construtorass.
45. Segundo a Norma ABNT NBR 5220, o município de Mirante do bioclimática 4 , enquanto o município de Mirandópolis localiza se na zona bioclimática 6 . A diretrizes construtivivas para zonas sāo as seguintes: 1) aberturas para ventilação médias; 2) aberturas sombreadas; 3) paredes externas pesadas e cobertura leve e isolada
Inverno; 4) paredes internas pesad 5) aquecimento solar da edificaçąao (só para ZB 4) Verāo; G) refrigeraçáa evaporativa; 7) inercia térmica para
resfriamento; 8) ventilaçáo seletiva (alguns horários). 
Figura 55. Implantação e (n) unidade construída do lote 172

Fonte: Grupo Habis, 201

46. O estudo das sombras foi realizado através do program que simula o caminho do sol e gera afícios circund producidas pelos ano em um determinado local. Esta analise permite avaliar a exposiç̧̧⿻ real do edifício considerando todos os elementos físicos circundantes.
13. Projeto executado: adequação e adaptação

\section{da moradia}

como um instrumento desenvolvido em um momento e um lugar diferente ao canteiro de obras, que adquire uma posição de dominação em relaçấo aos futuros moradores. Em outras palavras, o projeto, instrumento necessário à concretização do objeto arquitetônico, se torna apenas em um produto parcelar, isolado dos desejos e da autonomia dos futuros moradores e, consequentemente, acaba também por atribuir uma posição de autoridade sobre o trabalho alheio, aumentando a possibilidade de explorar ao máximo a força de trabalho sob seu comando e, assim, aumentar a taxa de mais-valia.

No trabalho de campo, encontramos projetos aparentemente definidos na etapa de concepçáo - inclusive provenientes de cadernos de projetos prontos - , sendo objeto de alteraçóes na própria etapa de execuçáo. De um lado, encontramos a construtora inserida num sistema em que o orçamento náo prevê lucro de terceiros. Desta forma, alguns elementos (como materiais e cômodos) comumente são eliminados ou têm sua qualidade reduzida ao limite das especificaçôes mínimas da Caixa, a fim de se criar uma margem de ganho. Por exemplo, este é o caso da varanda, que já seria insuficiente no projeto das 120 casas, foi descartada completamente pela empresa. Na avaliação da engenheira responsável, não foi um grande problema, pois "a maioria das famílias não se importa, porque a varanda era muito pequena, então as famílias iriam desmanchar para construir outra maior, de qualquer forma". Estas empresas apenas informam aos futuros moradores destas mudanças, os quais, pressionados pela 
necessidade de avançar na construçáo da casa, não encontram outra saída que năo seja aceitar as condiçôes da empresa.

De outro lado, seja a partir de deficiências originadas na etapa de concepçáo, somadas à inexistente participação das famílias nesta fase que, no melhor dos casos, limitou-se à escolha de uma planta única para todo o empreendimento - ou seja no mesmo processo de produção, com construtoras precarizando o projeto, os materiais de construçáo e a força de trabalho como fórmula para obter lucro, estas famílias, não têm outra opçáo que náo destinar recursos com o objetivo de adequar suas casas. Desta forma, aproveitando o processo de execuçăo, os futuros moradores alteram alguns aspectos das unidades habitacionais, encontramos algumas modificaçôes nos revestimentos cerâmicos, no posicionamento de esquadrias, material do forro e cobertura, e outras mais drásticas, como alteraçóes no programa inicial e adiçâo de novos cômodos como, por exemplo, a construçáo de varandas.

As análises anteriormente aplicadas aos projetos arquitetônicos permitiram compreender o nível de adequaçáo e qualidade das unidades estudadas, náo obstante a partir da pesquisa empírica foi possível apreender que, de um total de seis casos estudados nos assentamentos em questáo, em cinco foi constatada a significativa ampliaçáo de área, durante ou posteriormente à construçáo da moradia. Fato que demonstra, além da evidente inadequação destas moradias, as demandas latentes dos assentados.

Esta questấo relacionada com as alteraçôes das unidades se torna fundamental para nosso estudo, pois permite compreender não apenas as estratégias projetivas originais, como também o processo de mutabilidade das unidades habitacionais, segundo Bastos (2014) definido como flexibilidade contínua ou permanente, conceito que na prática é entendido aqui como as diferentes iniciativas das famílias no contínuo processo de adaptação da moradia às particularidades do meio rural e seu próprio modo de vida.

Este conceito de flexibilidade contínua relaciona-se com as estratégias que assegurem a adaptaçấo do espaço, tornando-o permeável às alteraçôes exigidas ao longo do tempo. Segundo Amorim et al. (2015, p. 104), sáo considerados dois critérios: a adaptabilidade (capacidade da edificaçáo de ajustar-se às necessidades de seus usuários, por meio de cômodos formalmente neutros) e a ampliabilidade (a capacidade da habitação de sofrer alteraçôes com acréscimo de área ou não). Para Bastos (2014, p. 45), deve ser considerada a estrutura do edifício préexistente como um suporte aberto à inserçáo de novos usos e programas, ou seja, pode absorver ou náo um programa totalmente diferente do inicialmente estabelecido, preservando sempre a estrutura pré-existente. Também o edifício deve suportar sua extensão para além dos limites pré-estabelecidos e se concretizar através da ampliaçáo do edifício para a área envolvente.

Baseado nos conceitos estudados, foi desenvolvido um estudo morfológico de uma unidade habitacional por contrato (figuras 56, 57 , 58 e 59). Para a construção desta ferramenta analítica são incorporados, de um lado, os sistemas tecnológicos (sistema estrutural, sistema de instalaçôes e sistema de cobertura) que, segundo Bastos (2014, p. 47) relacionam-se com o plano tectónico, influenciando a opçáo estrutural, 
material e construtiva do edifício, bem como a distribuiçáo das zonas de serviço, para a prática apropriada do conceito de flexibilidade. De outro lado, o sistema espacial, que se relaciona com a forma como o espaço é concebido, ou seja, a configuração arquitetônica e o modo como o morador interage e se apropria do espaço.

Cabe destacar que a complementariedade e a dependência destes sistemas (tecnológico e espacial) são notórias, uma vez que, conforme afirma Bastos (2014, p. 47), nenhum edifício pode ser funcionalmente satisfatório, albergando uma estratégia de caráter flexível, se não tiver um sistema estrutural adequado e vice-versa. Assim, a partir deste estudo morfológico, esta análise pretende explorar os limites e as possibilidades de alteração das moradias, que se resumem nas possibilidades de demolição ou modificação das paredes (internas e externas) encarregadas de compartimentar espaços.

Em termos técnicos, todas as unidades estão compostas por um módulo básico de banheiro, já que boa parte das paredes que o compóe suporta as instalaçôes hidrossanitárias e elétricas. Este módulo tem baixas possibilidades de ampliaçấo ou alteraçáo, pela complexidade técnica e pelo aumento no valor da obra no processo de demoliçăo e reinstalaçáo dos serviços domiciliares. Sobre a ampliação da cozinha, apesar de suportar parte das instalaçóes hidrossanitárias, em todos os casos estudados existe alguma possibilidade de ampliaçáo, principalmente pela posiçăo estratégica na organização espacial das unidades, comumente localizada no canto do módulo habitacional e próximo à varanda.

A respeito da adaptação dos espaços no interior da unidade,

principalmente nos quartos, em todos os casos existe alguma possibilidade de demolição, porém, com precaução na redistribuição dos cômodos existentes, por considerarem-se tipologias com uma organização espacial conservadora que dificulta conceber outros tipos

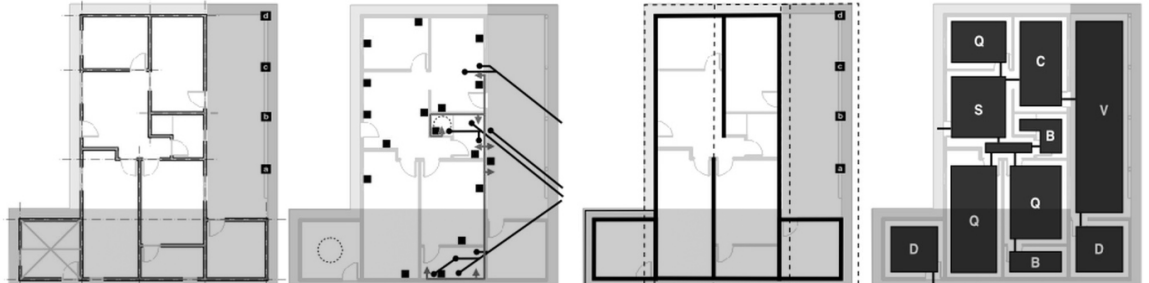

更

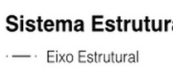

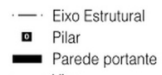
$\underset{\substack{\text { Sistema de Instal } \\ \rightarrow \text { Essoloponono }}}{ }$

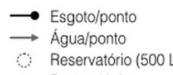

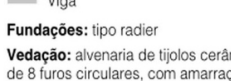

Sistema de Cobertur

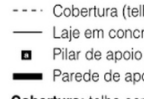

\section{sistema Espacial}

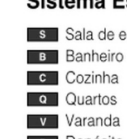

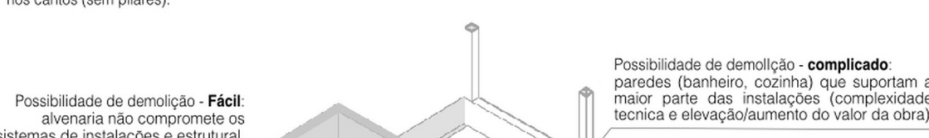

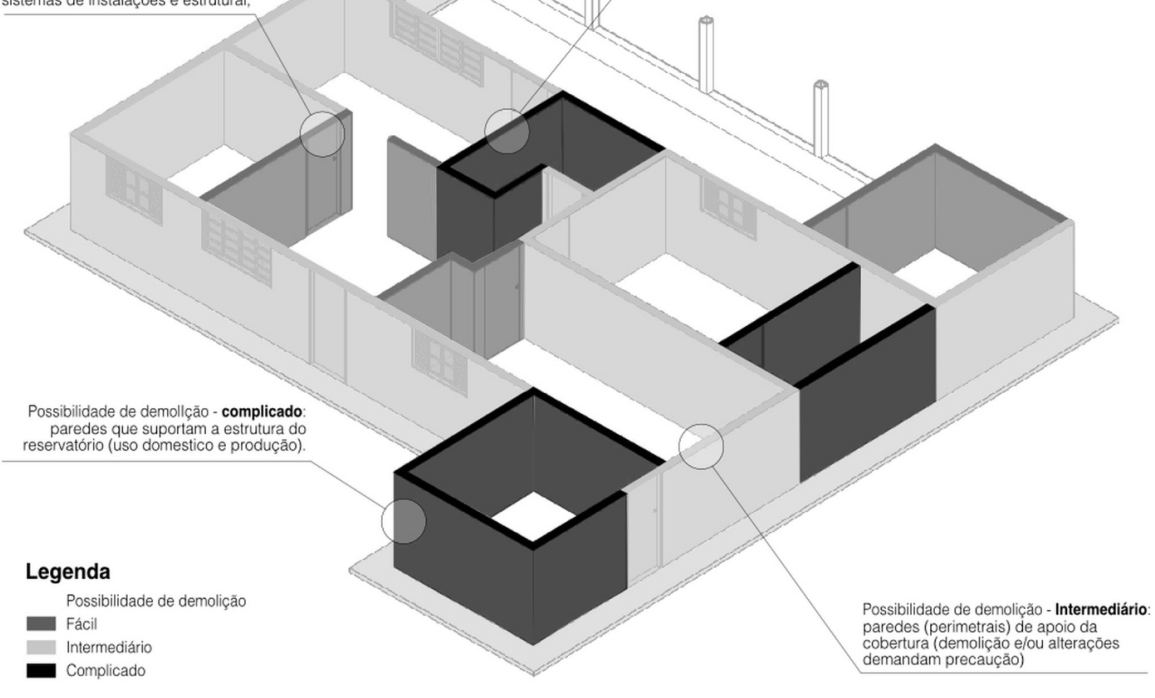

Figura 56. Estudo morfológico de flexibilidade do projeto
construído (lote 21) do contrat das 120 casas do assentamento
Florestan Fernandes Com alteraçōos do próps. Com Fonte: Elaborado pelo autor, 2018 

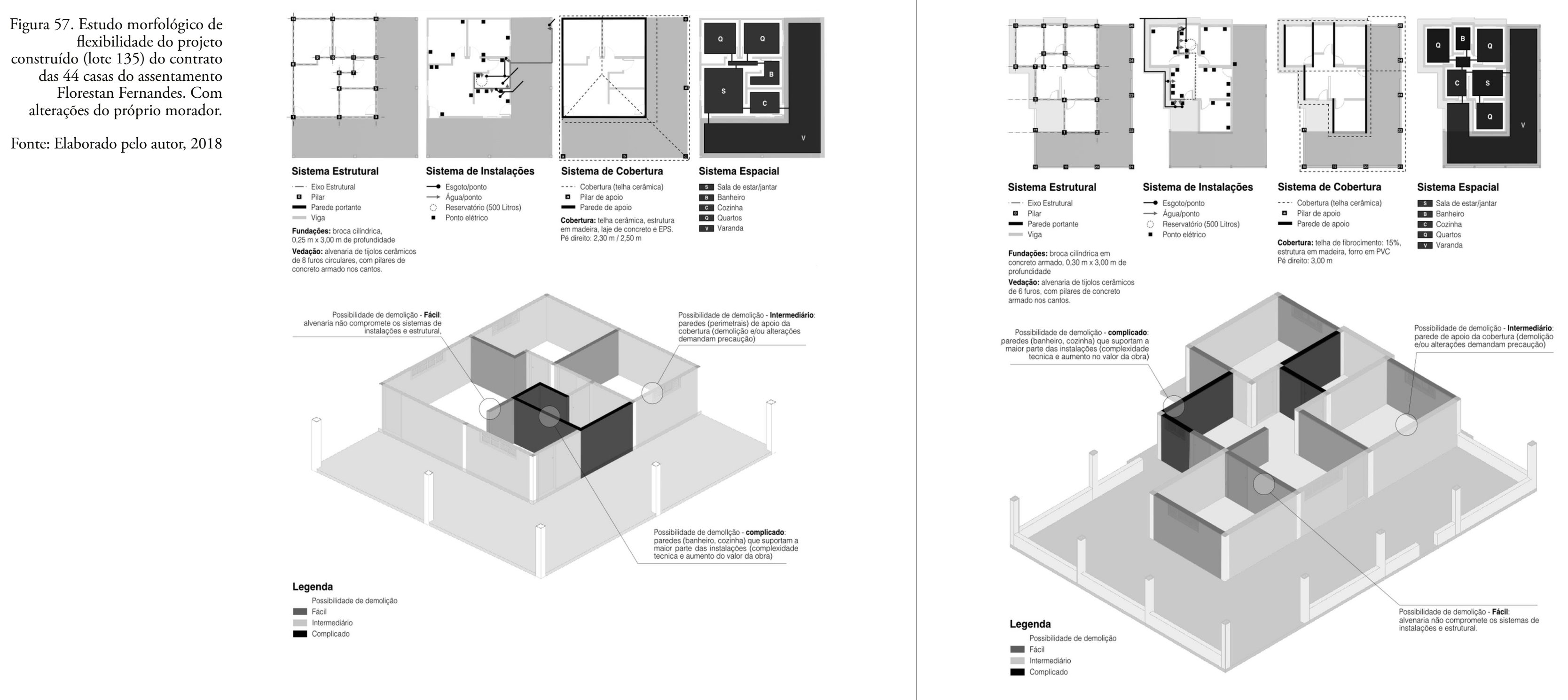

Figura 58. Estudo morfológico de flexibilidade do projeto construído (lote 135) do contrato Dona Carmem. Com alteraçōes 
Figura 59. Estudo morfológico de
flexibilidade do projeto

do (lote 158) do contrato

das 10 casas do assentamento

do próprio morador

Fonte: Elaborado pelo autor, 2018
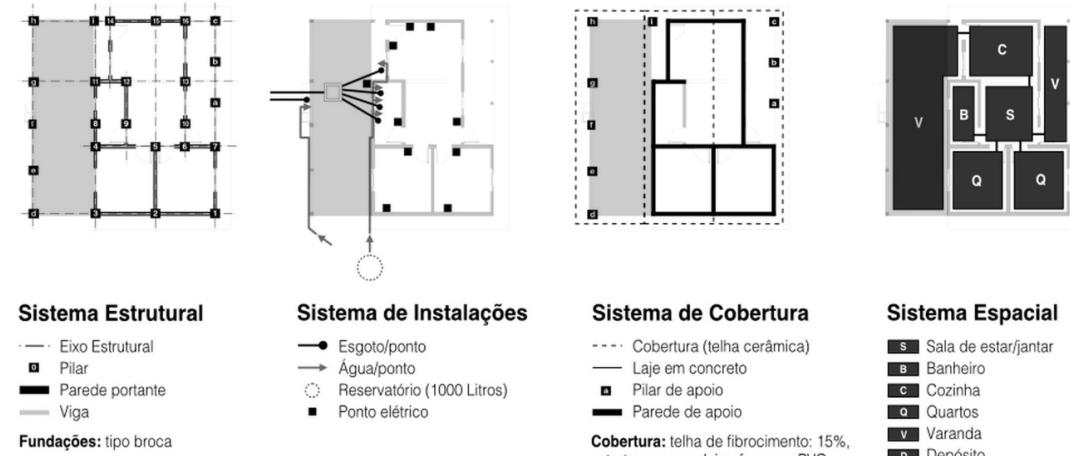

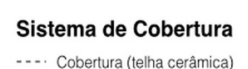

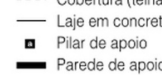

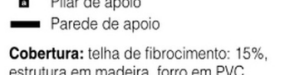
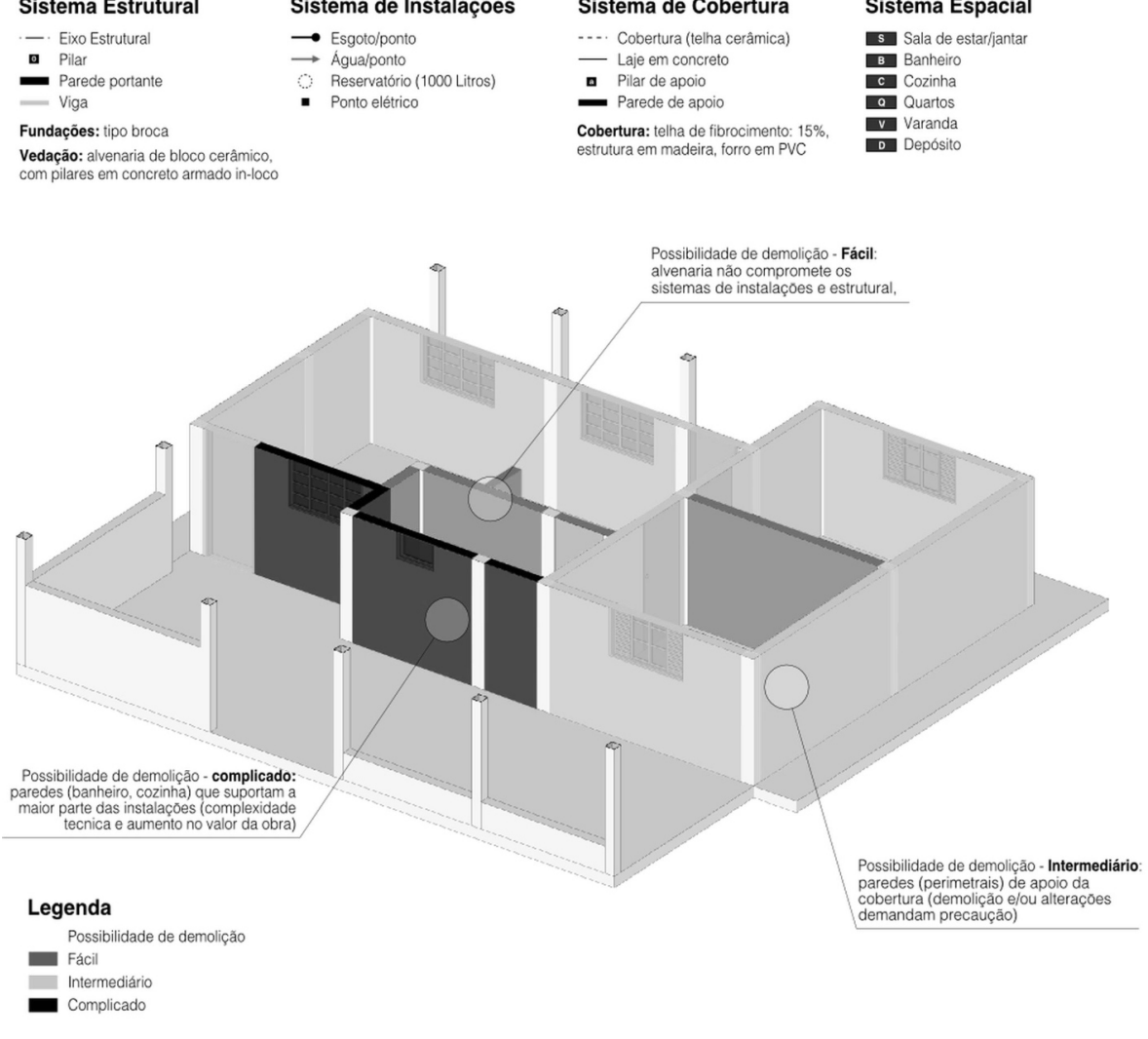

de arranjos. Também é possível mover uma parte da alvenaria interna sem comprometer a estabilidade da casa, porém, demanda precaução por causa da cobertura.
As soluçôes técnicas adotadas, por exemplo, fachadas (vedaçóes externas) que suportam completamente a cobertura junto com um sistema espacial extremamente rígido, limitam a possibilidade de acrescentar área externa da unidade habitacional. Nos casos das 120 e 44 casas do assentamento Florestan Fernandes (figuras 56 e 57) e 27 casas do assentamento Dona Carmem (figura 58), fica demonstrada a necessidade dos moradores de aumentar a área útil da casa. A construçáo de uma varanda, que no futuro pode se tornar a cobertura de um cômodo, é em uma das principais estratégias dos moradores para ampliar sua moradia de forma progressiva. Nestes casos, o único cômodo inalterável é o módulo do banheiro, por causa das instalaçôes e de sua posição na organizaçáo espacial da unidade.

Após as análises realizadas neste item, podemos destacar que, decorrente das deficiências surgidas da padronizaçáo do projeto e do próprio processo construtivo - técnicos que vieram dar soluçôes prontas, concebendo o projeto à sua vontade, e depois pelas máos de

\section{A busca de autonomia}

outros, o produto vai tomando forma —evidenciam-se "soluçóes" arquitetônicas convencionais que se repetem no Brasil inteiro, sem uma adaptação às necessidades da população. Estas afirmaçôes são frequentes no âmbito acadêmico, parecendo ser uma questấo óbvia. Contudo, no atual contexto, encontramos políticas neoliberais comandadas pelo mercado, com limitado planejamento público e sem nenhuma preocupaçāo com a participação popular e sem a autonomia das famílias beneficiadas, comumente restritas a determinadas normas pré-estabelecidas, como recursos limitados, dinâmicas operacionais 
inadequadas, materiais e sistemas permitidos e projetos arquitetônicos fechados.

Como consequência das deficiências mencionadas, os movimentos sociais que lutam por moradia consideram como imprescindível a garantia da participaçáo dos moradores enquanto autogestáo, capacitaçáo da populaçáo rural e autonomia no processo de concepção e construçáo do seu lugar de vida e trabalho. No entanto, a pesquisa empírica demonstra que as unidades habitacionais estudadas se configuram enquanto soluçóes pré-concebidas do ponto de vista arquitetônico e tecnológico, pensadas para uma demanda padronizada e estática. Em resumo, modelos habitacionais que negam a possibilidade de participação das famílias.

Náo obstante, apesar das dificuldades, o que encontramos no local são famílias tentando adaptar "minimamente" as unidades construídas à sua realidade, não tendo outra opção além de aplicar recursos próprios e dedicar aqueles períodos diferentes às atividades de produçáo agropecuária para reforma da própria casa. Como evidenciado no caso do lote 21 do assentamento Florestan Fernandes, com uma composição familiar de quatro membros, tiveram que investir aproximadamente $\mathrm{R} \$ 50.000,00$ na ampliação da unidade. Segundo o morador entrevistado, a casa era muito pequena para sua família e só forneciam uma opçáo de planta. Sendo assim, contratou um pedreiro para ajudar na ampliaçáo da casa. Este projeto em particular teve uma ampliaçáo de $55,43 \mathrm{~m}^{2}$ de área útil, na adiçẫo de $23,07 \mathrm{~m}^{2}$ de varanda, na ampliaçấo de dois quartos e dois depósitos (figura 60). Aqui, vale a pena problematizar as dimensốes que expressam a autonomia num cenário de carências, necessidades e muitas vezes de urgência que a moradia adequada representa para muitas destas famílias camponesas.

Também vale a pena destacar o caso do lote 135 do assentamento Florestan Fernandes. Na segunda visita ao assentamento, em julho de 2015, o morador e membro da CRE do grupo de 44 famílias deste

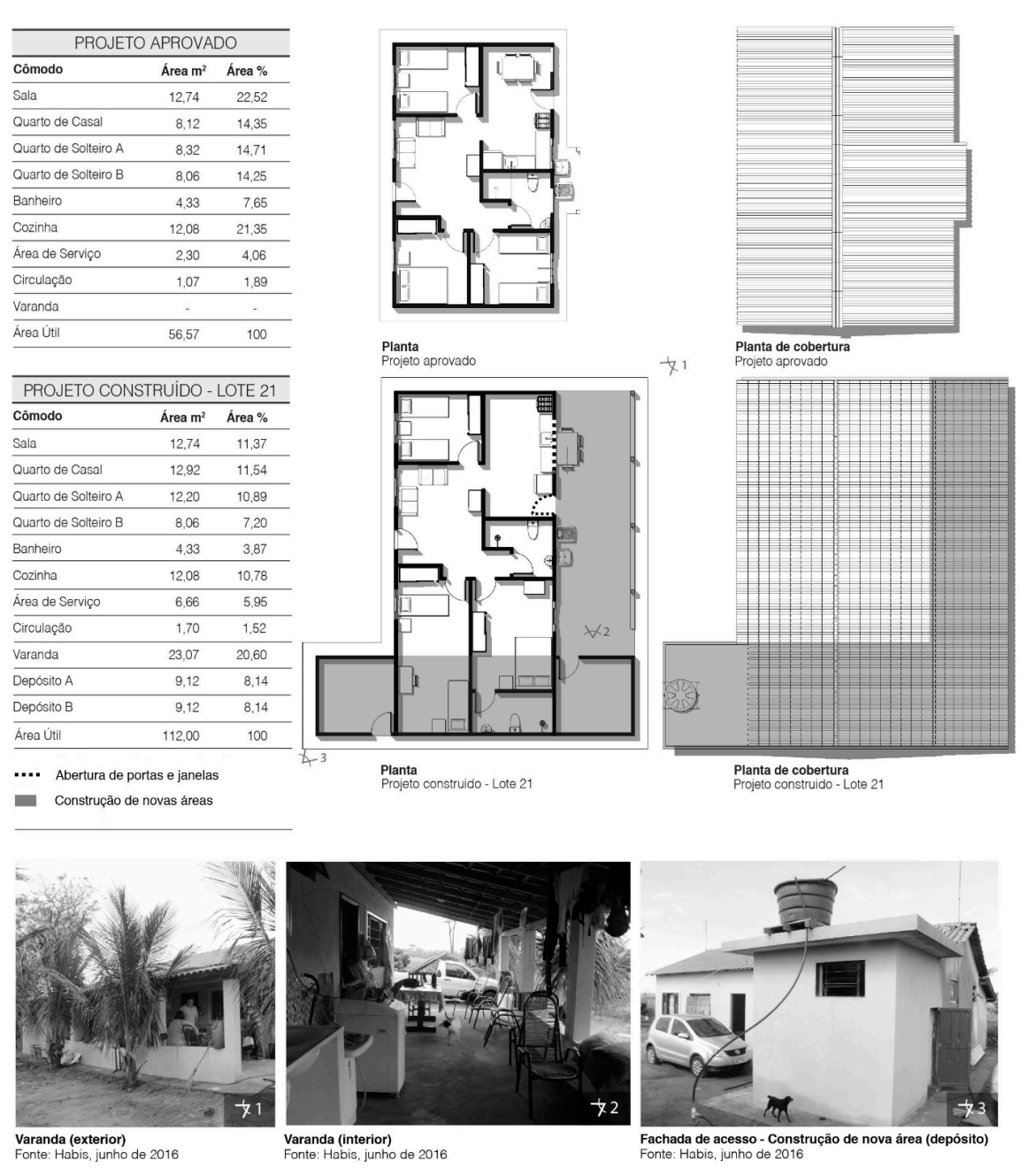

Figura 60. Programa com as áreas projeto construído com as alteraçóes (lote 21) do contrato das 120 casas do assentamento

Fonte: Grupo Habis, 2018 
Figura 61. Programa com as áreas
e as plantas do projeto aprovado o projeto construído com a das 44 casas do assentamento

Florestan Fernandes.

Fonte: Grupo Habis, 2018
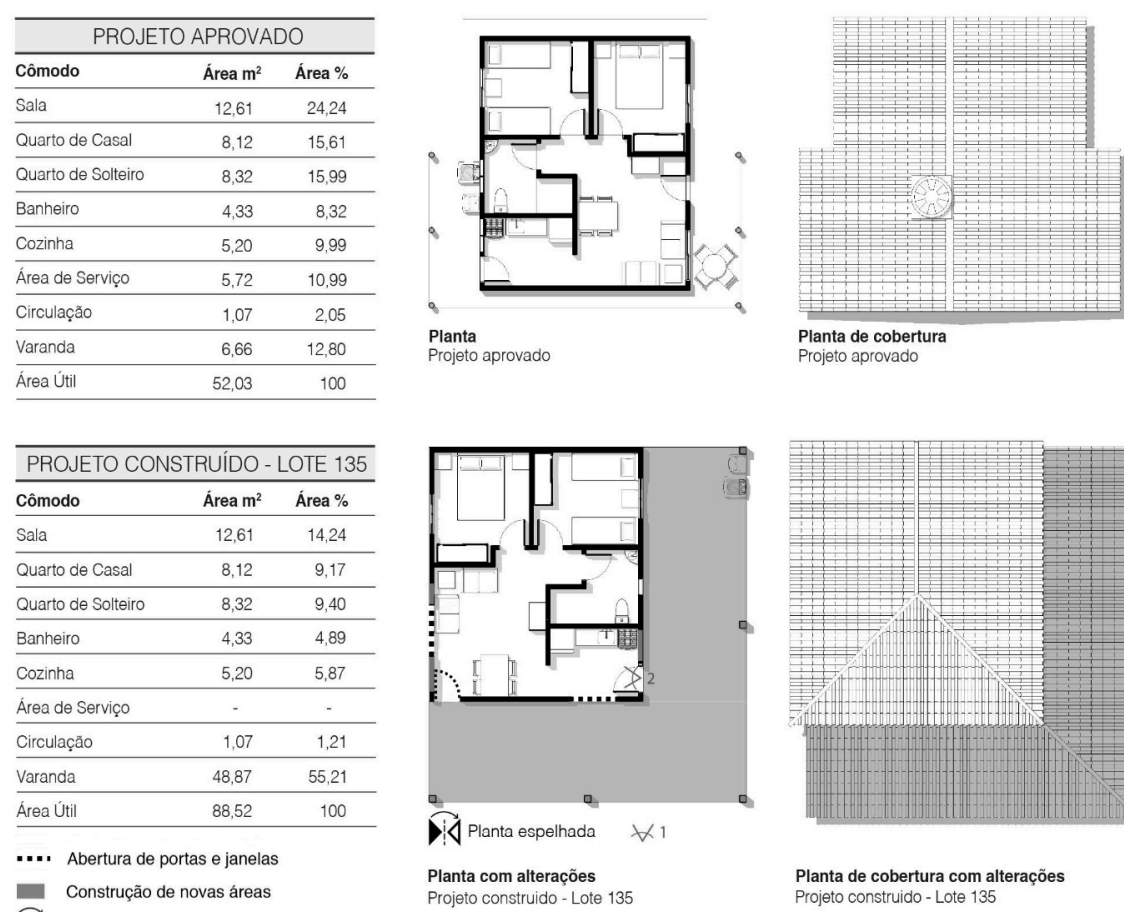

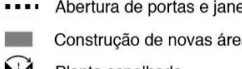

Aि

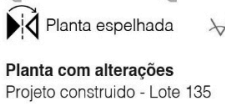
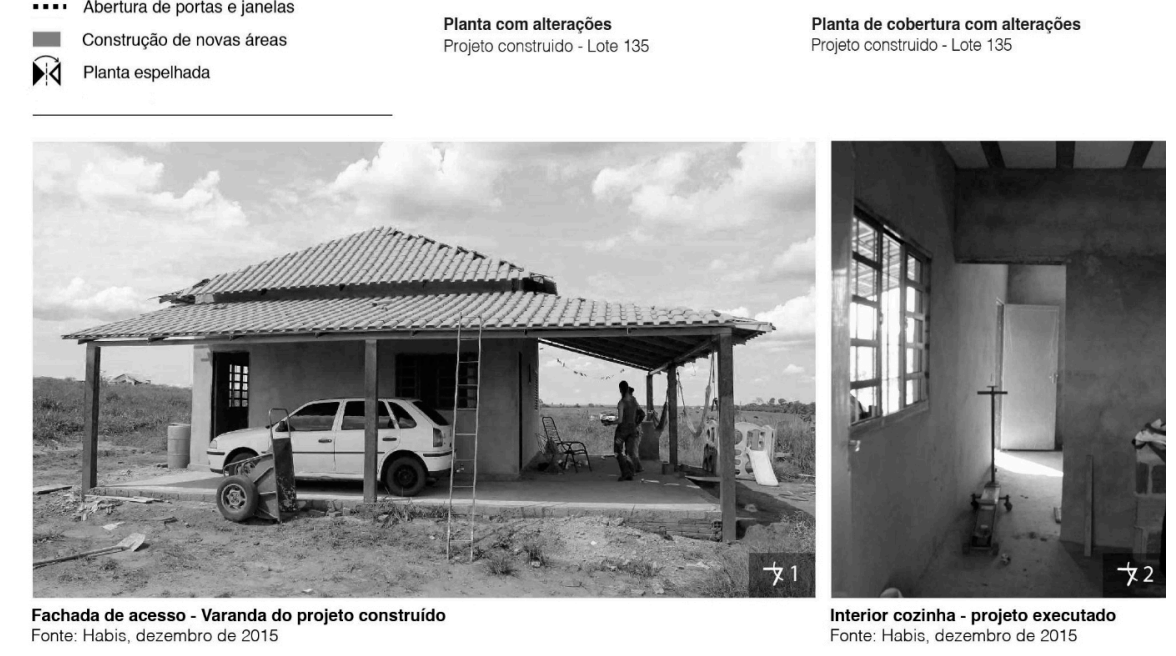

contrato decidiu construir sua casa de forma individual, por não confiar na gestão da Empresa B. Assim como no caso anterior, no lote 135 houve uma ampliaçâo da unidade, com $36,49 \mathrm{~m}^{2}$ de área útil de adiçấo na varanda (figura 61). Contudo, neste caso, o morador resolveu não contratar mão de obra para o processo construtivo, que foi assumida pelo próprio morador a partir da etapa de fundaçóes, momento que surgiram as discordâncias com a Empresa B. Destacamos também que, excluindo a varanda (construída com recursos próprios), foram aplicados os recursos definidos pelo programa.

Levando em conta a realidade encontrada, com processos de autoconstruçáo parciais - de caráter individual e não coletivo -, que acabam se mostrando como a única saída, faz-se pertinente a reflexão do arquiteto John Turner (1977), que destaca a importância de definir os limites práticos entre a heteronomia ${ }^{47}$ e seu oposto, a autonomia. $\mathrm{O}$ autor destaca como necessária a autonomia na produçáo de habitaçáo, contudo esta não é, e nunca poderia ser, absoluta, uma vez que sempre será necessária alguma dependência, geralmente dos recursos fundamentais que estáo fora do controle local ou pessoal. Na produção de habitaçáo, por exemplo, a autonomia e o controle que os usuários podem exercer dependeráo da disponibilidade das ferramentas, dos materiais, das terras e do financiamento que, em geral, dependem da autoridade central.

Nos casos mencionados, há uma combinação de centralizaçâo de recursos para materiais e mão de obra definidos pelo programa habitacional ao lado de agentes que encontram como única alternativa
47. Conceito usado

preferencialmente no âmbito da ética para denominar a sujeiciáo do
individuo à vontade de terceiros ou de uma coletividade, termo utilizado por Kant em oposiçăo à autonom 
para melhoraria de suas casas, responsabilizando-se pela produçấo total ou parcial das unidades habitacionais em processos de autoconstruçáo, apoiando-se nos seus próprios conhecimentos ou, em alguns casos, contratando máo de obra local.

É importante destacar que, embora este modelo reivindique de alguma maneira a autodeterminação, ao mesmo tempo é dependente do fundo público, ou seja, de recursos provenientes da autoridade governamental. Segundo a Usina (2015, p.94), esta condição se torna paradoxal, uma vez que constitui um campo de semiautonomia altamente conflituoso, que oscila entre a necessária repartiçáo da riqueza e uma perda progressiva de independência de suas organizaçôes.

A discussão anterior, somada às análises precedentes, permite-nos afirmar que estes processos de autoconstruçáo parciais praticados pelas famílias camponesas estudadas carregam uma grande contradição. Por um lado, estas adequaçóes das unidades habitacionais demonstram ir contra a centralização da produção da habitação no Estado, modelo que não prevê a participação dos usuários. Por outro lado, nas atuais condiçôes, à medida que o processo construtivo se restringe a atividades isoladas do coletivo e fica refém das limitadas regras do programa, acaba resultando na solução menos eficiente, já que não contribui com a possibilidade de se apresentar como uma proposta adequada, que resulte em alguma transformaçáo estrutural da sociedade.

No atual contexto de hegemonia de produção pública a partir de concessão privada, como acontece no Programa Nacional de Habitaçáo Rural, defender e praticar a autogestáo e a participaçáo direta na produçáo de moradia se torna um desafio. Desta forma, faz-se fundamental a crítica à estrutura de poder vertical e hierárquica, a emancipação política e, no canteiro de obras, à construçấo coletiva do conhecimento e o compartilhamento e do saber técnico como bem social. Um modelo no qual o arquiteto aparece em cena, como técnico inserido no processo coletivo de projeto e, principalmente, como articulador político e juntamente aos movimentos, se organizando em torno da questáo da moradia. 


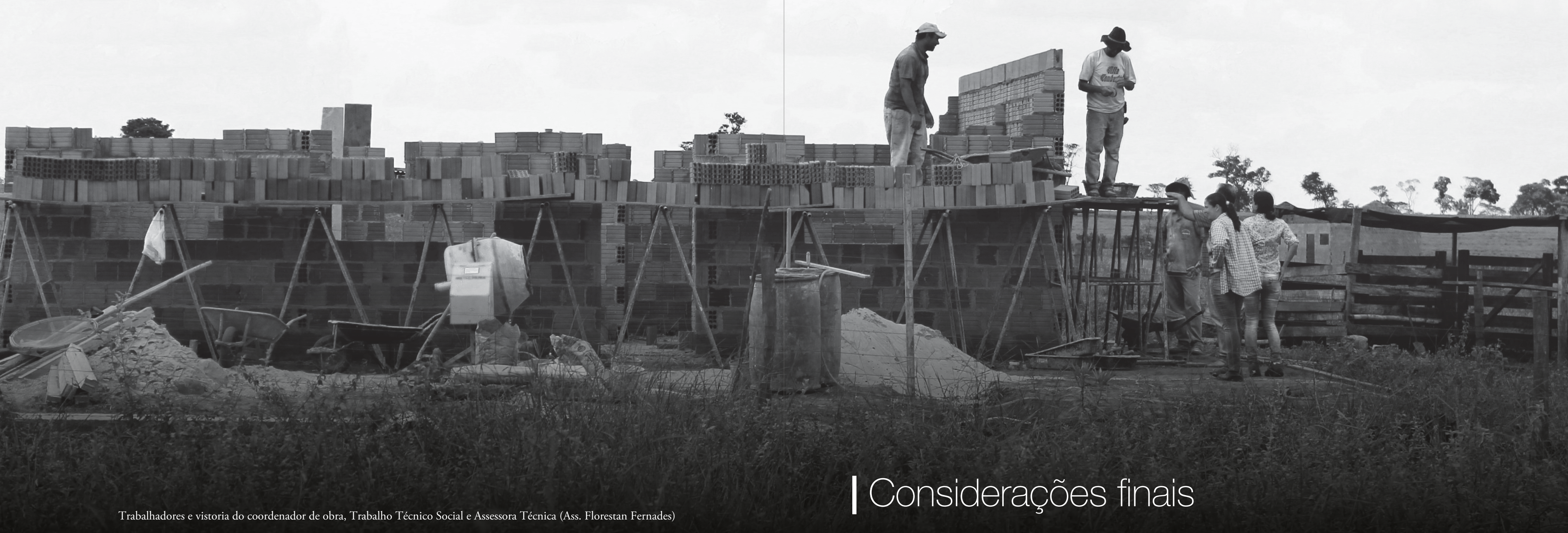




\section{Uma nova forma de produção de casa}

\section{camponesa?}

Conforme já mencionamos, o debate a respeito da produçáo habitacional nas áreas rurais do país (no caso específico, nos assentamentos de reforma agrária) ainda é incipiente no meio acadêmico, comumente considerado como um problema "resolvido", principalmente naqueles debates desprovidos de relevância científica e política, desligados da questão da reprodução ampliada do capital, e no campo da arquitetura e do panejamento, tratado como um "subtema" na política pública, termina se associando política, econômica e socialmente à dimensão urbana. Desta forma, o argumento deste trabalho reside na necessidade de compreender a formaçấo de novos arranjos de produção habitacional ao interior deste cenário, configurando-se como um tema relevante para o debate sobre as políticas e os programas habitacionais específicos para o campesinato brasileiro, pois é contraditório que continuemos concentrando nossos esforços apenas em $1 \%$ do território brasileiro ocupado por área urbanizada.

Em atenção aos objetivos propostos e para responder às questôes que mobilizaram esta pesquisa, apontamos que a construção crítica seja feita a partir do próprio objeto. Segundo Pereira (1988), para o entendimento da produção do espaço urbano - sendo aplicável para o campo brasileiro, a base de nossa análise - é necessário integrar a compreensáo sobre o funcionamento do processo produtivo da construção e as formas sociais de produçáo da construção e, desta forma, construir estudos mais rigorosos e que permitam uma visão abrangente. Em primeiro lugar, foram descritas as particularidades encontradas na produção habitacional destes assentamentos de reforma agrária, problematizando o funcionamento, a articulação e as dinâmicas da estrutura de provisão habitacional; a tecnologia e as características do canteiro; e o projeto de arquitetura, em todas as etapas, da concepçáo até a construção e a adaptação destas unidades habitacionais.

Para abordar teoricamente estes fenômenos, tornam-se importantes as categorias de análise do Samuel Jaramillo (1982), desenvolvidas no texto "Las formas de producción del espacio construido en Bogotá". Em primeiro lugar, cabe aclarar que, por "formas de produção", o autor se refere aos "sistemas que relacionam aos homens entre si e estes com os meios de produção para produzir um bem ou uma série de bens" (JARAMILLO, 1982, p. 175). Uma forma de produção é definida pela natureza dos agentes que intervêm neste processo, as posiçôes que ocupam (trabalho direto, controle técnico e controle econômico direto e indireto da produção) e as funçôes que desempenham, suas possíveis combinaçôes, conformando uma estrutura com as condiçóes necessárias para sua reproduçáo. Desta forma, o autor se refere à circulação, entendida como aquele processo que prepara os produtos e os distribui, começando pela produçẫo até sua fase final de consumo (JARAMILLO, 1982, p. 177)

Conforme já mencionado no objetivo, nestas consideraçôes finais pretendemos abordar, de forma conjunta, as reflexōes levantadas nos itens anteriores. Com o intuito de categorizar e interpretar a consolidaçâo das formas de produção habitacional observadas nesses contextos, pretende-se caracterizar náo apenas os diferentes agentes que 
intervêm no processo de produção-circulação, mas também aqueles atores que comumente não são considerados (como os arquitetos, técnicos, dentre outros), mas detêm um controle no processo. Também tentaremos capturar as diferentes contradiçôes frutos de suas interrelaçôes.

Vale a pena destacar que, nos países periféricos, como é o caso dos nossos países latino-americanos, o avanço da produçáo capitalista no setor da construção habitacional se dá de forma articulada às diferentes formas de produçáo do espaço presentes no lugar, expondo uma maio complexidade na compreensáo destes fenômenos. Segundo Jaramillo (1982):

Em certos setores e por diversas razōes coexistem "formas de produçāo" que podem diferir duquelas correspondentes ao modo de produço dominante, e que podem ser sobrevivências de modos de produçáo anteriores (aos quais está articulado o modo de produçāo dominante), ou produtos da maneira peculiar, como um modo de produção se insere em

Deste modo, distintas formas de produçáo operam de maneira simultânea, com dinâmicas endógenas peculiares, ou seja, que coexistem, combinam-se e articulam-se entre elas, transformando a formaçáo social na qual estão inseridas. $\mathrm{O}$ autor define a existência de quatro formas de produçáo-circulaçâo: produçáo por encomenda, que relaciona o contratante e o construtor responsável para executar a obra, a moradia destina-se ao uso direto do contratante, que tem o controle econômico direto da produçấo; promoçáo privada, voltada para a construçáo de moradias e a posterior venda do imóvel no mercado imobiliário, caracteriza-se pela acumulaçáo de capital através da apropriaçấo do trabalho excedente; a autoconstruçáo, quando realizada de forma individual ou por meio de mutirôes, nesta categoria o morador é o consumidor do bem e quem tem o controle técnico e econômico da produçăo; e capitalista "desvalorizada" por parte do Estado, voltada para atender às camadas da sociedade que, por causa da sua baixa renda, estão excluídas da produçâo capitalista habitacional.

Para fins deste trabalho, particularmente, dos cinco contratos estudados e seguindo a classificação elaborada por Jaramillo (1982), enfatizamos como objeto de análise a forma de produção capitalista "desvalorizada" por parte do Estado. Contudo, como já mencionamos, estas formas de produçâo apresentam alteraçōes ou combinam diferentes formas em um mesmo processo produtivo, situaçóes que se tornam ainda mais pronunciadas em países periféricos e dependentes. No texto " $L$ as heterogéneas formas de producción y consumo de la urbanización latinoamericana", Pedro Pírez definiu trinta e seis modalidades de produçăoconsumo da habitação e urbanização, evidenciando náo apenas a multiplicidade de situaçôes e combinaçốes que, também segundo o autor, dáo-se ao longo do tempo de maneira sucessiva, ou seja, um processo "que pode começar mercantilmente pode continuar nāo mercantilmente e retornar ao modo mercantil, e assim por diante com muitas combinaçōes" (PÍREZ, 2016, p.159), o que de fato demostra o caráter heterogêneo da produçáo de habitaçáo e da cidade.

\subsection{Os agentes envolvidos na forma de produçáo da}

\section{camponesa}

Como base desta análise e para a compreensão da forma de produção que está se consolidando nestes territórios, trazemos as categorias propostas por Jaramillo (1982), definidas como as principais posiçóes em que se desempenham certas funçóes (processos de apropriaçáo da 
natureza, coordenaçáo destes processos, repartiçáo dos resultados, etc): o trabalho direto é a ponta final da cadeia, ou seja, dentro da produçấo de um empreendimento habitacional é 'quem faz' e 'como faz'. Essa categoria engloba os processos de execuçáo, os trabalhadores envolvidos, as máquinas e as ferramentas utilizadas, os insumos, etc. $\mathrm{O}$ controle técnico da produção é o que efetivamente exerce controle sobre o trabalho direto, ou seja, quem controla e como controla. O controle econômico direto da produçáo refere-se aos agentes que têm o domínio dos meios de produção e o poder econômico interno e, a partir dele, interfere na produção. $O$ controle econômico indireto, por sua vez, também tem a ver com o poder econômico, porém externo à produção (JARAMILLO, 1982, 1986).

É importante indicar que estas categorias analíticas estão presentes em diferentes momentos do processo. Desta forma, neste trabalho foram consideradas as etapas de: operaçăo inicial do programa, relacionada com a regulamentação geral, a análise, a aprovaçáo, a contrataçáo dos projetos e o repasse de recursos; produção, considerada mais diretamente a etapa da construçáo ou execuçáo das unidades habitacionais, esta fase se relaciona ao trabalho direto e ao controle técnico no canteiro de obras; e a circulação, neste caso particular, considera alguns aspectos do consumo do bem.

Contudo, um mesmo agente pode estar presente em várias posiçóes e etapas diferentes, como é o caso, por exemplo, da CEF, que participa da operação inicial do programa e também interfere indiretamente com o controle técnico da produçáa, com o acompanhamento e as mediçóes das unidades para autorizar a liberação dos recursos. Essas combinaçóes de posiçóes e relaçôes entre agentes se tornam interessantes para compreender as particularidades da forma de produçáo em processo de consolidaçâo e sua operacionalização.

15.1.1. O trabalho direto no canteiro de obras

A respeito do trabalho direto em canteiro de obras, há um predomínio de emprego de mấo de obra para execuçáo dos cinco contrato estudados, motivado pelo alto índice de trabalhadores informais no campo e na cidade, a baixa escolaridade e seu o uso intensivo como forma de valorização de capitais, dentre outras. Contudo, destacamos que no empreendimento das 44 casas, houve alguma reduçáo na quantidade de trabalhadores por causa do uso do concreto usinado nas etapas de fundaçāo (estacas cilíndricas e contrapiso) e vedação horizontal (laje convencional), e o emprego de armaduras préfabricadas para as brocas de concreto e vigas baldrame. Em relaçáo à quantidade de máo de obra nas etapas do projeto, é nos serviços de alvenaria e fundação que intervêm a maior parte de trabalhadores.

A síntese precedente permite-nos aferir que, embora haja algum interesse pela busca de produtividade, a base produtiva nos canteiros estudados conserva-se com caráter manufatureiro, com o trabalhador estruturado na separaçáo e sequência das equipes durante todas as etapas da obra - como elemento imprescindível e central do processo, decisão deliberada das empresas construtoras, que com o objetivo de aumentar a taxa de lucro, concentram seus esforços no emprego abundante de máo de obra "barata", diminuem ao máximo o investimento de capital no uso de tecnologias, materiais e ferramentas convencionais, além da dificuldade intrínseca do capital para se apropriar do saber fazer do trabalhador. 
A segunda parte da pesquisa percorre da compreensão do canteiro de obras para a identificação das modalidades de subcontratação, onde se revela a natureza organizacional da máo de obra. De um lado, a subempreitada destinada a serviços mais "simples", na qual os trabalhadores eram organizados em equipes e seus "contratos" eram organizados junto ao mestre de obras. De outro, a chamada terceirizaçấo, caracterizada por executar serviços de maior especialização, como foi o caso da execuçáo das estruturas metálicas da cobertura das 120 casas. Estas modalidades acontecem de forma paralela com a contrataçáo direta de trabalhadores e um tipo de "autoconstruçâa", ou seja, camponeses (os futuros moradores) no trabalho voluntário e não coletivo.

Assim, está implícito que, a mão de obra empregada em canteiro está composta pela combinaçáo do trabalho assalariado e o trabalho voluntário, uma unidade hibrida que contém uma característica comum, o agravamento da exploraçáo do trabalhador. Apesar do evidente saber-fazer dos trabalhadores, os valores pagos săo muito abaixo do mercado, diferença ainda mais acentuada se comparada com os valores da cidade, situação que acontece e se intensifica em cada uma das modalidades de contrataçấo e subcontratação dos cinco contratos estudados. Somado a isto, camponeses que, por causa da necessidade da finalização da sua própria moradia, não têm outra alternativa que não seja trabalhar voluntariamente e sem remuneraçāo, camponeses que atuando no interior das regras impostas pelo programa habitacional, e as dinâmicas das empresas construtoras terminam reproduzindo as mesmas logicas dos outros regimes de construção.
15.1.2. Controle técnico da producão

Sobre o controle técnico da produçáo, cabe aclarar que consiste na "capacidade de regular a implementação dos meios de produção, a partir do ponto de vista do processo de trabalho: é o caso de funçóes como a coordenaçẫo dos distintos indivíduos e elementos que intervém na produçấo" (JARAMILLO, 1982, p. 176), que segundo o autor sảo a disciplina interna, os ritmos e horários e a programaçáo das tarefas. Considerando a afirmação anterior, apesar de o programa definir o assistente técnico (AT) para desempenhar estas funçōes - sempre seguindo as especificaçōes mínimas estabelecidas nos projetos de engenharia e arquitetura -, nos empreendimentos estudados, quem realmente é o responsável técnico das obras é o mestre de obras, agente subordinado à empresa construtora.

Assim, as empresas construtoras detêm o controle técnico da produçáo, responsáveis pelas funçôes de coordenação e fiscalizaçâo dos indivíduos, elementos e meios de produçáo que fazem parte do processo produtivo, tarefas comumente lideradas pelo mestre de obras ou por algum professional (da empresa), caracterizado por permanecer sempre no canteiro e com o conhecimento e domínio suficiente sobre o saberfazer. É importante considerar que a participação deste agente (empresa construtora) só aparece na fase de construção e após a finalização das obras, cede a responsabilidade à Entidade Organizadora pelas implicaçôes sobre o risco da operação e entrega das unidades às famílias. Apesar de ser tangencial a participaçáo das empresas construtoras, se torna decisiva no canteiro já que é este agente quem determina a qualidade do produto final, aqui encontra-se uma das principais características desta forma de produção. 
De outro lado, a Caixa Econômica Federal, por intermédio das Gerências Executivas de Habitação (GHAB) de cada estado, através das suas equipes técnicas, interfere indiretamente no canteiro de obras, fiscalizando por meio de vistorias técnicas o andamento e a execução das unidades. Quando dizemos que a fiscalização feita interfere indiretamente no canteiro de obras, quer dizer que das mediçōes e do controle exercido em canteiro sáo definidos os possíveis atrasos nas liberaçóes de recursos, fato que, consequentemente, altera o cronograma do contrato e estimula a reorganizaçáo do processo construtivo e a programação das tarefas.

Esta fiscalização é feita junto com o assistente técnico (AT), contratado pela Entidade Organizadora (EO), agente responsável por levantar as demandas habitacionais, entregar a documentaçáo dos beneficiários e das propriedades, elaborar e entregar os projetos técnicos de arquitetura e engenharia e do trabalho social, organizar a eleiçáo e entregar a composição da Comissão de Representantes ao Agente Financeiro para a análise e contrataçáo das operaçóes. Ou seja, participa na fase de operaçáo inicial, passando pela etapa de construçáo, ficando responsável por acompanhar as obras por meio da assistência técnica e, no fim das obras, pela entrega das unidades aos beneficiários. Entendemos esta nova posição como fundamental na formataçâo do

PNHR, com associaçōes, sindicatos ou cooperativas que operam paralelamente às suas atuaçóes políticas na luta pela terra e pela reforma agrária como gestores imobiliários.
15.1.3. Controle econômico direto da produção

Em princípio o controle econômico da produçáo concentra-se no capital "desvalorizado" estatal, representado nas instituiçóes financeiras, neste caso particular, a Caixa Econômica Federal, esta posição é sustentada na definiçāo do Jaramillo (1982):

Consiste no domínio sobre os meios de produçáo do ponto de vista definir suas características (quantidade e qualidade do produto, recursos atribuídos aos distintos componentes etc.), e também a disponibilidade econômica sobre o produto. (JARAMILLO, 1982, p.176)

Não obstante, em alguns casos, a empresa construtora investiu capital próprio devido à interrupçáo na liberação de recursos pela Caixa e, como aconteceu no contrato das 120 casas, devido às dívidas deixadas pelo anterior responsável do canteiro. Este capital privado permitia avançar com as obras do projeto para sua aprovação na próxima medição e as consequentes liberaçôes de recursos. $\mathrm{O}$ investimento deste capital privado alterou a dinâmica de atuação e a posição deste agente, abrindo a porta para um importante campo de acumulaçáo primitiva de capital, fundamentada nas estratégias de redução do valor de mão de obra e dos materiais.

Frente a este debate, nos parece importante destacar que, apesar de ser definida a autoconstruçấo assistida como único regime para os cinco contratos estudados, o próprio Agente financeiro permitiu a participaçáo e em alguns casos recomendou estas empresas construtoras para exercer o controle técnico da produçáo (como mencionado no item 14.1.2) e reservar para si mesmo parte do controle econômico direto, assim, sem muitas restriçóes, pode se tornar um nicho de mercado atrativo para muitas micro e pequenas construtoras. 
Para abordar a complexidade desta posiçāo, Jaramillo propôe o conceito de motor da produçáo, definido como "o elemento que comanda as decisóes e práticas do agente que detém o controle econômico direto e, portanto, estrutura a dinâmica da produçâo" (JARAMILLO, 1982, p. 176). O autor expóe o exemplo da produçáo capitalista, que exerce o controle em referência à acumulação de capital, definida como o motor da produção. Contrariamente à produçấo capitalista pura, no nosso caso particular, da construçáo promovida pelo Estado a partir de capital desvalorizado, com alteraçóes nas condiçóes de operação, como é a entrada de uma empresa construtora (capital privado), há uma combinação entre o valor de uso, reprodução da força de trabalho e a acumulação de capital.

Esta acumulação de capital (motor da produçáo), se baseia na taxa média de lucro da empresa que, após investir capital próprio, define como estratégia negociar os preços diretamente com os fornecedores, para assim obter uma reduçáo do valor gasto com os materiais, além da reduçáo do valor de mão de obra. Segundo umas das moradoras do contrato das 120 casas, o lucro da empresa só seria garantido com a liberação das últimas parcelas do projeto, posto que o dinheiro liberado pela Caixa vinha sendo utilizado na compra dos materiais.

\subsubsection{Controle econômico indireto da produção}

Como mencionado anteriormente, a capacidade de afetar o processo de produção desde o exterior é entendida como o controle econômico indireto da produçẫo, principalmente, "a partir do controle sobre as condiçōes gerais que enquadram o motor da produção, e por isso, que determinam e limitam o exerć́cio do controle econômico direto da produção" (JARAMILLO, 1982, p. 177). O autor destaca que, comumente na forma de produçáo capitalista "desvalorizada" por parte do Estado, os agentes que exercem controle econômico indireto são os organismos que comandam o mercado de terras e o aparelho político.

No caso citado pelo autor, o mercado da terra tem reestruturado drasticamente as dinâmicas de investimentos e arranjos na produção habitacional, com agentes - empresas construtoras e incorporadoras na recente produçáo habitacional no país - que atuam a partir de uma lógica de valorização imobiliária, concentrando terras que, posteriormente, usam para maximizar a extraçáo de lucros. Contudo, na produçāo habitacional em assentamentos rurais no interior do PNHR, acontece o contrário: a terra náo se configura em uma mercadoria, uma vez que o programa não oferece auxílio para compra de terras, exigindo a propriedade da parcela e, no caso das famílias beneficiárias do PNRA, estas devem ter a posse da terra para acessar o recurso destinado à construçáo da unidade.

A situação anteriormente descrita faz com que não seja possível a capitalizaçâo da renda fundiária nos assentamentos de reforma agrária, ou seja, encontramos empresas construtoras privadas sem a possibilidade de extrair lucros na aquisiçấo e comercialização de terrenos. Esta condiçáo, combinada com a produção habitacional estatal, estruturada na forma do subsídio, implica na reproduçáo das dinâmicas de acumulação primitiva de capital (motor da produçáo), principalmente no que se refere à superexploraçấo do trabalhador. 


\subsection{Projeto e Canteiro}

Um aspecto que determina algumas das principais particularidades do processo de produçáo habitacional nos assentamentos rurais se relaciona com a luta pela terra, nas fases de ocupaçáo, conquista e ressignificação destes territórios. Este processo de inserção territorial configura um modelo de urbanismo comumente sem planejamento e nem participaçáo da comunidade. Concentra as infraestruturas, os serviços e os equipamentos públicos nas áreas urbanas, dificultando gravemente seu acesso. Por exemplo, apesar de existir subsídios específicos para abastecimento de água e energia e sistemas de esgoto, o que observamos em campo são grupos de assentados investindo recursos próprios para solucionar a falta de água e energia. Inclusive, encontramos poços perfurados, mas sem conexōes efetivadas, especialmente devido aos conflitos decorrentes das articulaçóes institucionais. Esta ausência de redes de abastecimento de água e energia nos projetos de assentamento rural tem uma implicaçâo direta com relaçáo à fase de construçáa da habitaçắo, como a perda de recursos e materiais, atrasos nos cronogramas de obras, conflitos entre agentes e, ao final, o rebaixamento da qualidade das unidades.

A respeito do projeto, diante da não remuneração desta etapa, e da ausência de profissionais atuando em projetos de habitat e habitaçáo nas áreas rurais, os projetos executivos implementados nos contratos estudados acabaram sendo extraídos do próprio banco de projetos da Caixa, apenas com algumas adaptaçóes no seu orçamento aos subsídios mínimos do programa. Esta situaçáo, sem dúvida, terminou na padronizaçáo arquitetônica destes contratos PNHR, apresentando relaçáo direta com o trabalho no canteiro de obras.
Conforme o anterior e a partir das conhecidas experiências de autogestão na construção habitacional pelos movimentos de moradia, faz-se necessária a reconfiguração da forma de trabalho historicamente confeccionada pelo capital. Com a participação efetiva da comunidade, normalmente marginalizada no processo de concepçáo e de execução, será possível retomar o controle sobre seu trabalho e, sem dúvida, trazer benefícios físico-espaciais ao ambiente construído.

Finalmente, torna-se importante refletir sobre a prática profissional do arquiteto, a posiçáo que ocupa atualmente na consolidaçáo de novos arranjos de produçáo habitacional nestas comunidades, e que deve ser o seu posicionamento na formulaçấo de soluçốes para estes territórios. Hoje, observa-se que o arquiteto pouco tem atuado no meio rural brasileiro, principalmente nas áreas de assentamentos rurais, nas quais predominam as questôes que envolvem a produçáo do habitat e a habitação de interesse social e as comunidades nelas inseridas. $\mathrm{Na}$ verdade, a atuação do arquiteto esteve sempre voltada ao meio urbano e poucas sáo as iniciativas voltadas às camadas detentoras de um menor poder aquisitivo, dentre estas a população dos assentamentos rurais de reforma agrária.

No nosso entender, o arquiteto deve ser compreendido como aquele que utiliza o seu conhecimento com o intuito da transformação social, agindo de maneira política, tornando-se não somente em um simples técnico, e sim como agente, cuja funçáo social corresponde ao diálogo dos saberes, das ideias e dos sonhos dos grupos sociais envolvidos no processo, e levá-los para o espaço concreto. Este profissional deve extrapolar o simples ato isolado de conceber e executar para se tornar em um educador e agente transformador da realidade. 


\section{Construir novos territórios no meio do pós-conflito colombiano: considerações para} novos rumos

A contribuiçáo desta tese está em revelar as dinâmicas e os conflitos no processo de produçáo da moradia camponesa promovida pelo Estado nos assentamentos de reforma agrária. Essa contribuiçâo pode ser vista como um avanço para continuarmos refletindo náo apenas sobre a provisão de habitaçấo social no campo brasileiro, mas também sobre as constantes transformaçôes nos territórios rurais latino-americanos. Mudanças que se manifestam em suas estruturas sociais, produtivas e territoriais, onde coexistem todo tipo de mundos rurais heterogêneos. De um lado, encontramos grupos tentando se impor para modificar as gramáticas políticas e econômicas e, de outro, grupos tentando se adaptar às novas regras de jogo, de alguma forma, resistindo e se reorganizando a estas novas condiçōes e, em muitos casos, buscando estratégias para encontrar e integrar outros espaços territoriais (como é o caso das migraçóes).

Esta pesquisa propóe como recorte geográfico uma pequena área do território brasileiro, (Regiáo Oeste do estado de Sáo Paulo), caracterizada pela intensificaçấo da luta por terra e pelas condiçốes de precariedade com que se reproduz a maioria dos assentamentos de reforma agrária, marcados pela falta de infraestrutura, de serviços públicos, de apoio à produçáo, etc. No entanto, além destas dificuldades, o que se torna interessante para nossa pesquisa é o processo de territorialização destas áreas, a permanência de famílias na terra que há muito tempo estavam em situaçáo conflituosa, transformando estes assentamentos em espaços de produção, sociabilidade, intervençáo política, enfim, espaços de questionamento dos laços tradicionais de patronagem. Estes novos espaços permitem entender como, em muitos locais, acabou por se constituir uma dinâmica mais participativa e reivindicativa do que a tradicionalmente existente nos municípios brasileiros (MEDEIROS, 2005).

É precisamente aqui que encontramos um argumento que possibilitaria o direcionamento para futuras pesquisas, territórios rurais latinoamericanos imersos na condiçáo dupla, que imbrica adversidade e busca por emancipação. Um exemplo é a situação particular que se vive ainda com intensidade no campo colombiano, cenário de pobreza e violência pelos múltiplos conflitos relacionados nấo só aos fatores econômicos, mas também aos fatores sociais ligados ao uso e à tenência da terra ${ }^{48}$. Segundo Pérez et al. (2000), a complexidade do desenvolvimento rural do país é determinada justamente pela dimensão e natureza do conflito armado no qual se enfrentam diferentes grupos ${ }^{49}$ com diferentes métodos de ação, fato que está sendo agravado pela escassa participaçáo democrática de sua comunidade, pela incidência de fenômenos como o narcotráfico e pela constante dilatação ou falhas das reformas estruturais.

$\mathrm{O}$ atual conflito incide de forma negativa na estrutura de produçáo agrícola e pecuária do país, interferindo no potencial de crescimento do setor rural. Isto por causa do papel desempenhado pelos cultivos ilícitos $^{50}$ (coca, papoula e maconha), substituindo as áreas plantadas tradicionalmente. Sobre estes cultivos, Pérez (2009) afirma que os impactos na vida rural são grandes. De um lado, os impactos sociais, com tuxos populacionais descontrolados, decomposiçáo
48. Segundo o Departamento

Estadística (DANE), a Colômb

é um país com uma populaçăo de mais de 48 milhōes de pessoas, dos quais $24 \%$ moram no espaço rural. Deste território, atualment
$77 \%$ está nas mãos de $13 \%$ de proprietários, fato que confirma que, após 40 anos de tentativas de reforma agráría, anda náo problemática da concentraçáo da propriedade.

49. Grupos armados ilegais como s FARC (Fuerzas Armadas ELN (Ejército de Liberación Nacional); os paramilitares, grupos armados de extrema direita; e segurança do estado como: o
Exército e a Polícia Nacional.

50. De acordo o censo realizado pela UNODC (2003), no início hectares cultivads con cocis distribuídos em 23 dos 32 departamentos do país. São $68 \mathrm{mil}$ famílias rurais vinculadas a estes principalmente pequenos produtores e indígenas $\mathrm{em}$ pequenas áreas imersas em seus sistemas tradicionais de produçáo
com o objetivo de complementar suas rendas. 
transformação social e institucional, estigmatização dos camponeses vinculados, abandono dos conhecimentos sobre sistemas tradicionais de produção, presença de diferentes atores armados lutando pelo controle do território e especulação nos preços das terras. E de outro, os impactos ambientais e territoriais, com a destruiçáo de áreas protegidas; degradaçấo de solos cultiváveis; contaminação no processo de erradicação, ocasionando perda de cultivos lícitos, além de problemas de saúde para populaçáo; e problemas na regularizaçáo do território pelo estado acarretando principalmente dificuldades na implementaçáo de programas sociais de saúde, educação e habitaçáo.

Náo obstante, apesar das adversidades descritas, o país vem encontrando saídas à complexa situação do campo, com um necessário processo de diálogos de paz em Havana, em Cuba, com a guerrilha mais antiga de América Latina, as Forças Armadas Revolucionárias da Colômbia (FARC), com o objetivo de finalizar o conflito de mais de 50 anos com este grupo insurgente, negociaçóes que finalizaram com a assinatura do acordo em novembro de 2016. Cabe aclarar que os velhos problemas náo estáo desaparecendo, ao contrário, o final do conflito armado está evidenciando novas questôes que antes não percebíamos como, por exemplo, a ocupaçăo, o uso e a posse do solo e da moradia, os despejos devido às obras de desenvolvimento e à violência, entre outras situaçóes.

Estas transformaçốes sociais, econômicas e territoriais provocadas pelo acordo trazem para nós, arquitetos, a necessidade de compreender outras formas de organizaçấo espacial e comunitária. Este é o caso da conformaçáa de 24 novos assentamentos, definidos no processo de negociaçáo antes descrito, as Zonas Veredales Transitorias de Normalización (ZVTN) $)^{51}$, como conhecidas no início do processo, tinham como objetivo preparar a reincorporaçâo econômica, política e social dos ex-guerrilheiros à vida civil. Porém, com o tempo, essas áreas foram renomeadas como Espacios Territoriales de Capacitación Reincorporación (ETCR), tornando-se em espaços permanentes, na busca do fortalecimento do tecido social, convivência e reconciliaçáa objetivo que seria alcançado através do fomento a projetos produtivos, apoio financeiro, acompanhamento e treinamento técnico aos excombatentes e seus familiares.

É interessante pensar na consolidaçáo destes assentamentos, conformados por uma população com características únicas e irrepetíveis, como ter empunhado em armas para se rebelar contra o Estado; sua origem camponesa e indígena e o pouco contato com a cidade; e por terem vivido por décadas como nômades (comumente como fugitivos) e em condiçôes de habitabilidade muito precárias, em que o senso de comunidade foi e será essencial para sua sobrevivência.

Apesar disso, torna-se fundamental apontar alternativa ao melhoramento da atual política de habitação rural no país. Apesar da Colômbia ser um dos países da América Latina com maior tradição em termos de políticas de habitaçáo social, estas novas condiçōes e as próprias transformaçóes do campo colombiano exigem uma curva de aprendizado significativa mediante a concepção e implementaçáo de diversos modelos e soluçôes habitacionais adequadas encaminhadas para atender às diferentes necessidades habitacionais da população de baixa renda destes territórios.
11. Ver "De las Zonas Veredales la Paz Territorial. Tensiones, conflictos y retos en el suroccidente
de Colombia" de Heinrich Böll de Colombia"d
Stitung (2018) 
Segundo o estado colombiano, o Programa de Vivienda de Interes Social Rural (VISR) com subsídio à demanda, é o mecanismo pelo qual o governo contribui a melhorar as condiçốes de vida dos habitantes rurais de escassos recursos econômicos, famílias afetadas por desastres naturais ou em situação de calamidade pelo conflito interno. $\mathrm{O}$ programa está concebido para dois tipos de organizaçấo rural: dispersa, e agrupada, e se operacionaliza por meio de entidades organizadoras, como governos estaduais, prefeituras, e conselhos comunitários legalmente constituídos.

Finalmente, poucos avanços podem ser vistos na melhoria das condiçōes de vida dos camponeses colombianos, apenas $13 \%$ da demanda por moradia foi satisfeita, além da tendência a favorecer os municípios com maior capacidade financeira, deixando a maioria da populaçâo mais pobre fora deste benefício.

De acordo com o exposto, no atual cenário latino-americano, marcado por diversas crises políticas, econômicas e sociais, entendemos como um grande desafio a simples compreensão dos diversos mundos rurais. Portanto, espera-se que os resultados alcançados neste trabalho - e de futuras pesquisas - permitam traçar caminhos para repensar políticas e programas sociais, na procura de compensar aqueles que têm sofrido os efeitos relacionados às disputas que estáo ocorrendo no campo. 


\section{Referências Bibliográficas ${ }^{52}$}

ALMEIDA, A. J. de. A participaçáo de assessoria técnica-política e da CAIXA na produçáo de moradias em assentamentos rurais. Casos: Fusquinha, Nova Esperança e Rirituba 2 . (Mestrado) - Universidade Federal de São Carlos UFSCar, São Carlos, 2008 .

AMORE, C. S. "Minha Casa Minha Vida" para iniciantes. In: AMORE, C. S.; RUFINO, M. B. C.; SHIMBO, L. Z. Minha casa... e a cidade? Avaliaçáo do programa minha casa minha vida em seis estados brasileiros. Instituto de Pesquisa e Planejamento Urbano e Regional - IPPUR/UFRJ. Rio de Janeiro: Letra Capital, 2015.

AMORE, C. S.; RUFINO, M. B. C.; SHIMBO, L. Z. Minha Casa... E a Cidade? Avaliaçáo do Programa Minha Casa Minha Vida em seis estados brasileiros. Rio de Janeiro: Letra Capital. 2015.

AZEVEDO, S. de.; ANDRADE, L. A. G. Habitaçáo e Poder: da Fundaçâo da Casa Popular ao Banco Nacional da Habitaçán. Rio de Janiro: Zahar Editores, 1982.

M. Housing Analysis: Time For a Theoretical Refocus? Housing n. 3, p. $147-166,1986$.

BARAVELLI, J. E. Trabalho e tecnologia no Programa MCMV. 2014. 226 f. Tese (Doutorado em Habitat) - Faculdade de Arquitetura e Urbanismo, Universidade de São Paulo, São Paulo, 2014

BASTOS, M. I. P. A incorporaçáo do conceito de flexibilidade na arquitetura: como resposta a um mundo em permanente mutaçáo. 2014. Dissertaçâo. (Mestrado) -Universidade Lusíada do Porto. Porto, Portugal, 2014.

BONDUKI, N. G. Habitaçáo e Autogestấo: construindo territórios de utopia. Rio de Janeiro: Fase, 1992.

BRASIL. Decreto-Lei No 9.777, de 06 de setembro de 1946. Estabelece bases financeiras para a "Fundação da Casa Popular" e dá outras providências. Rio de Janeiro, 1946.

_ Governo Federal. Estatuto da Terra (1964). Lei n. 4.504, de 30 de novembro de 1964. Diário Oficial [da] República Federativa do Brasil, Brasília, DF, 28 dez. 1964. Disponível em: <http:// www.senado.gov.br/sicon>. Acesso em: 10 out. 2018.

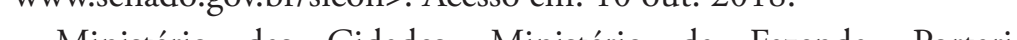
- Mnte inistia No 186, de 7 de agoro de 2003. Disponver an: . <http://www. fazenda.gov.br>. Acesso em: 5 jun. 2015.

- CONPO DE SERVICOO Re DO FUNDO DE GARANTIA DO TEMPO DE SERVIÇO. Resoluçáa n ${ }^{\circ} 460$, de 14 de dezembro de 2004. Diário Oficial da Uniáo, Braśília, 20 dez. 2004.

CANDIDO, Antonio. Os Parceiros do Rio Bonito: estudo sobre o caipira paulista e a transformaçăo dos seus meios de vida. São Paulo: Duas Cidades, 1998.

CARAFFA, M. Projeto de assentamento rural. Um estudo do ambiente construído no Zumbi dos Palmares - Iaras/SP. 2014. $171 \mathrm{f}$. Dissertação (Mestrado em Habitat) - Faculdade de Arquitetura e Urbanismo da Universidade de São Paulo. São Paulo, 2014.

CARVAlHO, A. W. B; PAULA, N. E. S.; PEREIRA, D. A. G. Programa Nacional de Habitaçáo Rural e modo de morar no campo reflexóes a partir da casa rural na Zona da Mata mineira. III Coloquio Habitat e Cidadain Habiaço no campo, nas aguas e Coloquio Habitac e Cidadania, Habitaçao no campo, nas aguas e nas florestas. Brasilia,

CASTAÑEDA, R. A. Qualidade da habitação nos Assentamentos Rurais no PNHR/PMCMV do estado de Sáo Paulo. Casos: Florestan Fernandes, Dona Carmem e Boa Esperança. 2016. $191 \mathrm{f}$ Dissertaçăo (Mestrado em Arquitetura e Urbanismo) - Instituto de Arquitetura e Urbanismo da Universidade de Sáo Paulo. Săo Carlos 2016

CERQUEIRA, Maria Cândida Teixeira de. A assistência técnica nos habitats do MST e o papel do Aruiteto e urbanista Dissertaçāo (Mestrado em Arquitetura e Urbanismo) - PP-GAU/ UFRN, 2009

- Reconstituindo o desenho do habitat de reforma agrária Legados e Possibilidades para o Estado. 2019. Tese (Doutorado em 
Programa de Pós-Graduação em Arquitetura e Urbanismo) Universidade Federal do Rio Grande do Norte, 2019.

COMISION ECONÓMICA PARA AMÉRICA LATIN Anuario Estadítico de América Latina y el Caribe CEDAL ECLAC, 2018.

COMUNIDADE DA CONSTRUCÁ̃. Alvenaria de Vedaçáo com blocos de concreto. Associação Brasileira de Cimento Portland. Recife, 008.

OSTA, I. B. da \& MESQUITA, H. M. Tipos de habitaçáo rural no Brasil. Rio de Janeiro, SUPREN. Superintendência de Recursos Naturais e Meio Ambiente/IBGE, Fundaçáo Instituto Brasileiro de Geografia e Estatística. 1978.DELGADO, G. A questão agrária no Brasil, 19502003. In: JACCOUD, L. (Org.). Questáo social e políticas sociais no Brasil contemporâneo. Brasília: Ipea, 2005.

FARAH, M. F. S. Processo de trabalho na construçáo habitacional tradiçáo e mudança. São Paulo: ANNABLUME, 1996.

FARIAS, A. R. et al. Identificaçáo, mapeamento e quantificação das áreas urbanas do Brasil Campinas: Embrapa Gestão Ambiental. Comunicado técnico 4, 2017. 5 p.

FERREIRA, T. L. Dos sonhos de uma casa a casa dos sonhos: moradia e qualidade de vida na comunidade Terra Livre. 2007. 150f.

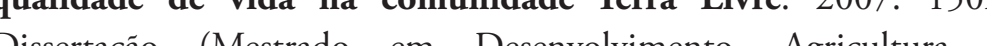
Sociedade). Intituto de Ciên. Dess Hum e Socinis, Univeride Solo ro, Rio de Janeiro, RJ, 2007.

FERRO, S. A produção da casa no Brasil. (1969). In: ___ Arquitetura e trabalho livre. São Paulo: Cosac Naify, 2006. p. 61-101

"Trabalhador Coletivo" e Autonomia. In: VILAÇA, I, "Trabalhador Coletivo" e Autonomia. In: VILAÇA, I CONSTANTE, P. (Orgs.). USINA: entre o projeto e o canteiro. Sáo Paulo: Aurora, 2016. p. 21-30.

GAMA, R. Tecnologia e Trabalho. In: ___ . A Tecnologia e o Trabalho na Historia. São Paulo: Nobel/Edusp, 1986.

GUIMARÃES, E. P. M. Moradia e consumo no campo: mudanças e permanências face ao processo de urbanizaçáo na zona rural de
Araponga, MG. 2013. Dissertaçáo (Mestrado em Economia Doméstica) - Universidade Federal de Viçosa, 2013.

HEIDEGGER, M. « Bâtir, habiter, penser » in: Essais et Conférences, Ed. Gallimard, 1990, p. 190

HESPANHOL, N. A.; COSTA, M V H.; ESPÍRITO SANTO, R. C. Assentamentos e os reassentamentos rurais na Regiâo de AndradinaP. In: BERGAMASCO, S. M. P. P.; AUBREE, M.; FERRANTE, V. L. (Org.) Dinamica familiar, Produtiva e cultural nós assentamentos Rurais de Sáo Paulo. Araraquara: Ed UNIARA, NCRA, 2003.

INSTITUTO BRASILEIRO DE GEOGRAFIA E ESTATÍSTICA - IBGE. Censo Demográfico 2010. Sinopse. 2011. Disponível em: <http:// www.censo2010.ibge.gov.br/sinopse/>. Acesso em: 22 jul. 2018.

JARAMILLO, S. Las formas de producción del espacio construido en Bogotá. In: PRADILLA, E. (Ed.). Ensayos sobre el problema de la viviend en México. Cidade do México: Latina Unam, 1982. p. 150-210. . Las Formas de Producción de Vivienda en Medellín 1930-1980. Desarrollo y Sociedad, Bogotá, v. 17-18, p. 53-102, 1986.

. Heterogeneidad estructural en el capitalismo. Una mirada desde la teoría del valor trabajo abstracto. Territorios, Bogotá, v. 34, n. I, p. 59-85, 2016.

LAWRENCE, R.J. The qualitative aspects of housing: a synthesis. Building Research and Practice, London, v.18, n.2, p.121-125, 1990 Research and Practice, London, v.18, n.2, p.121-125, 1990.
. What makes a house a home? Environment and Behavior, Beverly Hills, v.19, n.2, p.154-168, Mar./Apr. 1987.

KELLER, E. O habitat rural. In: AZEVEDO, A., org. Brasil: a terra e o homem. Volume II. São Paulo, Companhia Editora Nacional, USP p.291-345. 1970

LEFÈBVRE, H. Introduçáo ao estudo do 'habitat pavillonnaire'. In: De lo rural a lo urbano. 4. ed. Barcelona: Península. (Historia/ciencia/ socieda. Serie universitaria, 79). Antologia preparada por Mario Gaviria. Versão espanhola de Javier González-Pueyo do original francês. 1978 
LEMOS, Carlos A. C. Casa paulista: história das moradias anteriores ao ecletismo trazido pelo café. Sáo Paulo [SP]: EDUSP, 1999, 264p. LEMOS, Carlos. A. C.História da casa brasileira. Sáo Paulo: Contexto, 1989.

LENZI, C. C. A habitaçáo camponesa no programa MCMV. 2017. 139 f. Dissertaçăo (Mestrado em Arquitetura e Urbanismo) - Instituto de Arquitetura e Urbanismo, Universidade de Saao Paulo. Saao Carlos. 2017.

LOPES, J. M. de A.; LENZI, C. C.; BORGES, A. H. O habitat da 'nấo cidade' como um problema para a arquitetura e urbanismo. Paranoá: Cadernos De Arquitetura e Urbanismo, Brasília: UNB, n. 17. 2017.

MEDEIROS, L. S. de. "Sem Terra", "Assentados", "Agricultores familiares": consideraçóes sobre os conflitos sociais e as formas de organização dos trabalhadores rurais brasileiros. In: GIARRACCA, N. ¿̨Una Nueva Ruralidad en America Latina?. Buenos Aires: Libronauta Argentina S. A., 2005. p. 407.

MARICATO, E. Por um novo enfoque teórico na pesquisa sobre habitaçáo. Cadernos Metrópole, São Paulo, v. 21, p. 33-52, 2009.

MARQUES, C. A. Habitaçáo: da Indústria à Fábrica da Cidade. Casal de Cambra: Caleidoscópio, 2012.

MARX, K. O capital: Livro I. São Paulo: Boitempo, 2002. p. 894.

OLIVEIRA, A. U. de. A agricultura camponesa no Brasil. 4.ed.- Sáo Paulo: Contexto, 2001.

—. Geografia Agrária: perspectivas no início do século XXI. In: OLIVEIRA, A. U.; MARQUES, M. I. M. (orgs.) O Campo no Século XXI: território de vida, de luta e de construçáo da justiça ocial. Sáo Paulo: Editora Casa Amarela e Editora Paz e Terra, 2004. p. 29-70.

. Modo de produçáo capitalista, agricultura e reforma agraria. São Paulo: FFLCH/USP, 2007

OLIVEIRA, F. de. O vício da virtude: autoconstruçáo e acumulaçáo capitalista no Brasil. Novos estud. - CEBRAP, São Paulo, n. 74, p.
67-85, Mar. 2006

PEREIRA, P. C. X. Espaço, Técnica e Construçáo: o desenvolvimento das técnicas construtivas e a urbanizaçáo do morar em Sáo Paulo. São técnicas construtivas
Paulo: Nobel, 1988 .

PERES, R. B. Habitaçáo rural. Discussáo e diretrizes para políticas públicas, planejamentos e programas habitacionais. 2003. Dissertaçáo (Mestrado em Arquitetura e Urbanismo) - Universidade de Sảo Paulo, São Carlos, 2003.

PÉREZ, M.; FERNÁNDEZ, L.; ALEGRE, F. Planificación en territorios rurales. Proyección, Mendoza, v. 1, n. 6, p. 01-21, 2009

PÍREZ, P. Las heterogeneidades en la producción de la urbanización y los servicios urbanos en América Latina. Territorios, Bogotá, n. 34, p. 87-112, 2016.

- Las heterogéneas formas de producción y consumo de la urbanización latinoamericana. Quid 16, Buenos Aires, n. 6, p. 131167,2016

PRADILLA, E. Notas acerca del problema de la Vivienda. In: . El problema de la

PUELLO, M. "Agrópolis o el fin de la ciudad-territorio" aportes conceptuales para un planeamiento físico de base agropolitana. Bitácora Urbano

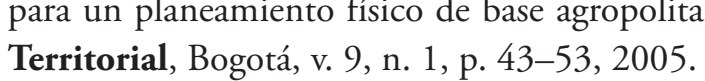

RAPOPORT, A. Vivienda y Cultura. Barcelona: Editorial Gustavo Gili, 1972.

ROVER, O. J.; MUNARINI, P. R. A política de habitaçấo rural e o desenvolvimento da agricultura familiar. Revista Katálysis, Florianopólis, v. 13, n. 2, 2010.

SHIMBO, L. Z. Sobre os capitais que produzem habitaçấo no Brasil. Novos Estudos - CEBRAP, São Paulo, v. 35, n. 02, p. 119-133, 2016

_. Habitaçáo Social, Habitaçáo de Mercado a confluência entre Estado, empresas construtoras e capital financeiro. 2010. $361 \mathrm{f}$ Tese (Doutorado em Arquitetura e Urbanismo) - Escola de Engenharia de Sáo Carlos da Universidade de São Paulo, 2010. 
SILVA, C. M. G. da. Habitaçáo Rural: uma luta por cidadania. 2014 Dissertação (Mestrado em Planejamento Urbano e Regional) Uissertaçáa (Mestrado em Planejamento

TURNER, J. F. C. Vivienda: todo el poder para los usuarios. Madrid: $\mathrm{H}$. Blume, 1977.

Usina CTAH. Arquitetura, política e autogestấo: um comentário sobre os mutiróes habitacionais. in: Usina: entre o projeto e o canteiro. 2015.

VALADARES, A. A. O gigante invisível: território e populaçăo rural para lém das convençốes oficiais. Brasília: IPEA, 2014.

VARGAS, M. Técnica, tecnologia e ciência. Revista Educaçáo \& Tecnologia. Universidade Federal Tecnologia do Paraná: Curitiba, v. 6, mai. 2003.

VARGAS, N. "Racionalidade e năo-racionalizaçâao". In: FLEURY, A. Organizaçáo do Trabalho. São Paulo: Atlas. 1983.

VEIGA, J. E. Desenvolvimento territorial do Brasil: do entulho varguista ao zoneamento ecológico-econômico. In: ENCONTRO NACIONAL DE ECONOMIA, 29., 2001, Salvador, Bahia. Anais... Salvador: ANPEC, 2001.

VILLA, S. B.; ORNSTEIN, S. W. (Org.) Qualidade ambiental na habitaçáo. São Paulo: Oficina de Textos, 2013. p.343-358.

ZUQUIM, M. de L. O lugar do rural nos Planos Diretores Municipais. In: PLURIS - Congresso Luso Brasileiro para Planejamento Urbano, Regional, Integrado e Sustentável, 3º., 2008. São Carlos. Anais... Sáo Carlos: STT/CETEPE/EESC/USP, 2008.
18. Anexos

18.1. Roteiro de entrevistas semiestruturadas

\section{Entrevista com o Morado}

1. PROCESSO DE APROXIMAÇÃO COM O PNHR

1.1.1. Onde estava localizada sua moradia anterior (campo: sítio, fazenda, assentamento, ocupação; cidade: loteamento urbano, favela, outro)? Sua moradia anterior era própria, alugada, cedida, compartilhada, outra? Tem essa moradia ainda?

1.1.2. Histórico da família no assentamento: Por que escolheram um assentamento e por que este assentamento? Participaram da fase de acampamento os não?

1.1.3. Como foi sua participacáo no processo de organizaçáo do "Grupo das Casas". Motivacóes que os levaram a construir/methorar a case Quem construiu a moradia antiga? De onde vieram os materiais?

2. INFRAESTRUTURA, EQUIPAMENTOS E SERVIÇOS

2.1. Infraestrutura no Assentamento.
2.1.1. Sua casa já possui energia elétrica e água encanada? Se sim, como funcionam as contas? Há casos de falta de água ou energia?

funcionam as contas? Ha casos de falta de ågua ou energia?
2.1.2. Vocês pensaram em sistemas de captaçăo e reservatórios de água?

2.1.2. Como sáo feitos os tratamentos de água/esgoto?
2.1.

2.1.3. Como sáo feitos os tratamentos de água/esgoto? 2.1.4. No seu lote, como sáo tratados os residuos? Vocè sabe se existe um sistema os programa de reciclagem de alguns residuos no assentamento ou no município? Você recicla ou reutiliza seus resíduos?

2.1.5. Quem cuida das estradas do assentamento? Quem abriu a estrada para o seu lote?

2.1.6. Qual entrada para o assentamento você utiliza mais? A sinalizaçáo (placas indicativas) está adequada?

3. PROJETO E PRODUÇÃO DA HABITAÇÃO

3.1. Projeto Arquitetônico 
3.1.1. Houve participaçáo na definiçáo do projeto (tamanho, numero de cômodos, materiais, etc.)? Se sim, como se deu essa participaçāo? Foi um modelo padrão ou elaborado pelo grupo?

3.1.2. Você pretende fazer alguma alteração na casa? Os projetos consideram possibilidades de ampliaçăo, reforma ou alteraçáo em sua planta original?

3.1.3. Você recebeu algum documento referente ao projeto da casa? a) Contrato (com a empresa construtora, com a EO, a AT, com a máo de obra) b) Apresentação do PNHR (Cartilha, Folheto, etc.); c) Planta com medidas; d) Planta sem medidas; e) Descriçāo dos materiais utilizados na construçāo; f) Descrição de instalaçoes; g) Outra.

3.2. avaliaçăo da unidade pelo morador

3.2.1. A casa do PNHR ficou muito diferente da anterior? Melhor? Em que? $\mathrm{O}$ que você acha que falta na planta? (Esta primeira pergunta é mais exploratória. Direcionar a conversa com as perguntas seguintes).

3.2.2. Comparado com sua moradia anterior, você diria que o tamanho $d a$ moradia atual: a) Aumentou; b) Diminuiu; c) Está igual.

3.2.3. O tamanho da casa atual está adequado ao tamanho da família (os cômodos estáo bem dispostos e dimensionados)?

3.2.4. Sente falta de algum cômodo ou ambiente? Por que? 3.2.5. Na sua avaliação a casa apresenta algum problema? Qual (os quais)? 3.2.5. Na sua avaliaçáa, a casa apreschta algum problen Qual (os quais)?

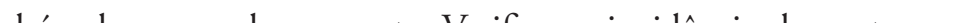
a bussola, para sa o note. Verifica

Questóes e itens a serem verificados durante as visitas nas casas.

As unidades preveem a instalaçáo de sistemas de captaçáo e armazenamento de aguas pluviais e geraçăo de energia eólica e solar? Todos os componentes estáo devidamente impermeabilizada contra umidade? As aberturas estáo posicionadas corretamente, seguindo a orientaçāo da casa? Os sistemas de cobertura (incluindo telhados e forros) foram instalados corretamente, garantindo proteção contra infiltraçōes e prevenindo possíveis danificaçōes da unidade, decorrentes de ventos fortes? A instalaçáo dos revestimentos internos estão prevenindo infiltraçôes e acúmulo de umidade, sobretudo nas áreas molhadas? As dimensōes das portas internas e externas estão respeitando as exigências previstas na NBR 9050? Há instalaçâo de corrimăos e pisos antiderrapantes, sobretudo no banheiro e na cozinha?

3.3. Trabalho Técnico Social.

3.3.1. O responsável pelo Trabalho Técnico Social visitou o seu lote? Quantas vezes? Houve reunióes coletivas? Antes e/ou durante as obras? Quais atividades foram realizadas? 3.3.2. Discussão sobre a organização e/ou regras de convivência 3.3.3. Temas técnicos referentes às unidades.

3.4. Dinâmica de Aplicaçáo e Gestáo dos Recursos

3.4.1. Quantos atrasos ocorreram nas liberaçōes dos recursos? Algum serviço foi prejudicado? Houve perdas de materiais?

3.4.2. Você investiu recurso próprio na construçăo da sua moradia? Qual fo o valor aplicado? Para qual etapa?

3.5. Canteiro de Obras.

3.5.1. Você vivenciou a construçáo da sua casa (ou parte dela)?

3.5.2. Você participou do processo de construçăo da sua casa (ou do vizinho)?

3.5.3. Você tomou emprestado a dom equip

3.5.3. Voce tomou enpestalo algun equpane 3.5.4. Existe algum lugar para o estoque do material do canteiro no Exento ou fora dele?

\section{Entrevista com a Entidade Organizadora (EO)}

1. DEMANDA

1.1. Histórico.

1.1.1. Como se constituiu a Entidade Organizadora? Há quanto tempo existe? Quem săo e quantos sáo os integrantes? Onde a se de está localizada? 1.1.2. Aproximaçăo ao PNHR. Relatar o processo de adequaçấo necessário para entrar no programa (dificuldades, burocracias, etc.).

1.1.3. Qual o principal ramo de atuaçáo da EO? Vocês trabalham com outros projetos similares? Quais e onde?

1.1.4. Histórico de formação do assentamento: a) Existência ou náo de ocupaçáo para conquista do terreno; b) Qual era o uso da terra antes da desapropriaçăo; c) Movimentos envolvidos na ocupaçáo; d) Tempo de espera até a regularizaçāo; e) Número de lotes e tamanhos; f) Existência de 
infraestrutura no assentamento (água, luz, estradas, saneamento, comércio, creche, escola, posto de saúde).

1.1.5. Relaçăo com os demais agentes: a) Processo de organização das famílias, dos documentos e aproximação com a empresa construtora; b) Relaçáo com prefeituras, outros movimentos; c) Relaçáo com a CEF

EIXO 2. INFRAESTRUTURA, EQUIPAMENTOS E SERVICOS

2.1. Infraestrutura no Assentamento.

2.1.1. Período no assentamento sem água e energia; Formas de captaçáo, armazenamento, abastecimento e irrigação encontradas pelas famílias Quantas familias possuem acesso e quantas năo possuem? Por quais motivos? 2.1.2. Estáo discutindo a possibilidade de implementar sistemas de geração de energia por fontes renováveis? Da mesma forma, estáo discutindo outros sistemas de reuso de água, tratamento de esgoto, reciclagem, compostagem e reaproveitamento de resíduos?

2.1.2. Há tratamento de efluentes no assentamento? Quais resíduos são tratados? Há riscos de contaminaçáo do solo e do lençol freático?

2.1.3. Quantos acessos/entradas existem no assentamento? Eståo sinalizadas? Quando as estradas foram executadas? Por qual empresa? Quais as suas condiçōes atuais? Quem são os responsáveis pela manutençăo? Há erosōes e riscos de deslizamentos em dias de chuvas?

2.1.4. Hierarquizaçăo das estradas (principais e secundárias) e sua relação com os fluxos de vida e trabalho das famílias e com a obra

Observača: Indicar no mapa do assentamento as estradas, os acesos e os Observaçáo: Indicar no mas
pontos de parada de ônibus.

EIXO 3. PROJETO E PRODUÇÃO DA HABITAÇÃO

3.1. Projeto Arquitetônico

3.1.1. Houve participaçăo da EO e das famílias na definiçăo do projeto (tamanho, numero de cômodos, materiais, etc.)? Se sim, como se deu essa (tamanho, numero de cômodos, materiais, etc.)? Se sim, como se deu essa participaçao? Foi un modlo padráa ou daborado pelo grupo?

3.1.2. Os projetos consideram possibilidades de ampliaçấo, reforma ou alteração em sua planta original?
3.1.3. Quais os documentos/contratos firmados com a empresa construtora? 3.1.4. A EO teve alguma dificuldade com a documentacăo? 3.1.5. Quando a EO deu entrada na CAIXA com a documentaçăo?

3.2. Trabalho técnico social.

3.2.1. Você teve contato com o responsável pelo Trabalho Técnico Social? Em que momento do processo? (antes do inicio das obras; no momento da construçáo das casas; depois da mudança; náo teve contato) Com qual periodicidade?

3.2.2. Como foi a relaçáo com o responsável pelo Trabalho Técnico Social? Quais as atividades previstas? Estas atividades seguiram algum roteiro da CAIXA? Foram discutidas com as famílias?

3.3. Dinâmica de Aplicaçấo e Gestão dos Recursos.

3.3.1. A EO precisou investir recursos próprios na obra? Qual o valor? Em quais etapas? Por que?

3.3.2. Quantos atrasos ocorreram nas liberaçóes dos recursos? Algum serviç̧o foi prejudicado? Houve perdas de materiais

3.3.3. Você sabe se tem algum morador que investiu recurso próprio na construçáo da moradia dele? Você sabe dizer uma estimativa do valor aplicado?

3.3.4. A finalidade deste investimento esteve relacionada a alguma alteraçáo no projeto ou alguma complementaçán na planta original? (ampliaçáo dos ambientes, troca os perda de material, etc.).

\section{Entrevista com a Empresa}

0. TRAJETÓRIA DA EMPRESA

0.1 . Quando surgiu a empresa e quais os tipos de projetos que a empresa atua? 0.2 . Já havia trabalhado em assentamentos rurais (ou no meio rural) antes? Onde? Quando?

0.3. Como foi o envolvimento com a EO para a participaçáo neste projeto?

0.4 . Já participou do PMCMV urbano? Se sim, quais e onde? Quais as diferenças/dificuldades/vantagens? 0.5. Já participou ou pretende participar 
de outros projetos do PNHR? Quais? Onde?

EIXO 3. PROJETO E PRODUÇÃO DA HABITAÇÃO

3.1. Projeto Arquitetônico.

3.1.1. Como foi o processo de concepção do projeto? Este projeto está sendo aplicado em outros contratos?

3.1.2. Os projetos consideram possibilidades de ampliaçâa, reforma ou alteraçáo em sua planta original?

3.1.3. Aconteceram modificaçóes no projeto durante o processo de construçáo das casas? Quais?

3.1.4. Quais documentos foram entregues à Caix

3.1.5. A empresa produziu algum tipo de cartilha/manual?

3.1.6. Foram assinados contratos diretamente com as famílias, com a $\mathrm{EO}$

com os trabalhadores? Quais contratos? Para qual finalidade?

3.2. Infraestrutura.

3.2.1. Qual a infraestrutura existente no assentamento no início do processo construtivo? E qual a infraestrutura náo existente? Como a empresa contornou este problema?

3.2.2. As obras foram prejudicadas pela condiçāo das estradas ou por outro fator relacionado à infraestrutura?

3.2.3. Quais os principais resíduos gerados durante o processo de construção das casas? O que foi feito com estes resíduos? Existe alguma empresa de reciclagem de resíduos da construção civil no município ou na regiâa?

3.3. Dinâmica de Aplicaçáo e Gestão dos Recursos.

3.3.1. Quantos atrasos ocorreram nas liberaçóes dos recursos? Algum serviço

foi prejudicado? Houve perdas de materiais? 3.3.2. A empresa aplicou recursos próprios

obra? Para quais etapas? Qual o valor total? 3.3.3.A interrupção na liberaçáo dos recursos alterou o projeto (defasagem no preço dos materiais; elaboraçáo de novo orçamento; exclusão de elementos de acabamento ou outros; etc.)?

3.3.4. Houve alguma dificuldade os algum imprevisto com relaçáo ao controle financeiro da obra e à gestáo da obra - que também alterou o projeto?
3.3.4. A empresa é responsável pela elaboração da PLS?

3.4. Fornecedores de Materiais e Equipamentos.

3.4.1. Fornecedores de Materiais e Equipamentos Para a construtora: pedir a lista dos fornecedores de materiais de construçáo, suas localizaçóes, as quantidades adquiridas, as marcas e os valores, Para os fornecedores: razão social, localizaçăo, porte e abrangência da empresa e procedência dos materiais de construçấo fornecidos na obra (tijolos, cimento, cal, areias, brita, tubulaçăo, madeiras, telhas, esquadrias, aço, revestimentos cerâmicos, louças, metais).

3.4.2. Como funcionaram as compras de materiais? a) Padráo das negociaçóes de compra (à vista, à prazo); b) Quem fez/faz a cotaçáo dos materiais?. c) Como funcionam as entregas e os estoques? Quem acompabs procese? d) A empresa possu agum gapo para estoque dos Logista de tranporte/distribuça dos materiais (da lojaldo estoque a canteiro).

3.4.3. Fornecedores de Equipamentos: a) Para a construtora: pedir a lista de fornecedores de equipamentos utilizados na obra (caminhão betoneira, geradores, betoneiras, furadeiras, fôrmas); b) Para a empresa fornecedora razăo social, localizaçấo, porte e abrangência da empresa; c) Quanto custou o aluguel destes equipamentos? d) Quais ferramentas e equipamentos foram compartilhados ou emprestados?

3.5. Canteiro de Obras.

3.5.1. Mão-de-obra no canteiro: a) Como foi o processo de contrataçấo dos pedreiros serventes e mestres? b) De onde vêm a máo de-obra? Já to dos experiên experiencia de trabalho na constrçáa civil c) Rara quais etapas houve a necessidade de náo de obra especializada. Qual anprest esponsavel e onde ela se localiza? Qual o valor do serviçọ? d) Como funciona o pagamento dos pedreiros, serventes e mestres? e) Quais os valores das empreitas?

3.5.2. Organizaçáo dos gastos da obra: a) Como funcionam os repasses dos recursos (da CRE para a empresa)? b) Como foram orçadas as etapas de cada serviço (Referência do $\mathrm{m}^{2}$ da Tabela SINAPI)? c) Qual o lucro da empresa? d) Quem faz a gestão dos recursos? Existe alguma planilha para o controle dos gastos? e) Como funciona a prestação de contas para a CAIXA ou para a EO? 
f) Quem faz o controle das notas fiscais?

3.5.3. Medicōoes das obras: Quantas mediçoes foram feitas? A mediçāo é feita por amostragem? Quais os critérios para a escolha da amostragem? A empresa acompanha as mediçōes?

4. Avaliaçôes e Perspectivas.

4.1. Qual a sua avaliaçáo com relaçáo à participaçáo neste projeto e com relaçấo ao PNHR? Você acha que o programa pode ser melhorado?

\section{Entrevista com o Trabalhador}

0. TRAJETÓRIA PROFISSIONAL

0.1 . Você mora no assentamento? Se náo, onde? Quanto tempo leva para chegar ao assentamento? Qual o meio de transporte utilizado 0.2. Qual a sua principal fonte de renda (e da sua família)? Este serviço tem 0.2. Qual a sua principal fonte de renda

0.3. Você possui (ou já teve) carteira assinada? Quando e para qual atividade? 0.4. E beneficiário do PNHR? Se não (e for assentado), por que? .5. Qua a experiência com a construçáa civil? Como foi su for Qual o seu nível de escolaridade? Há quanto tempo você trabalha na construção civil? Você exerce algum outro ofício além deste? Você já trabalhou na construção civil em outras cidades/regiôes?

\section{EIXO 3. PROJETO E PRODUCÃO DA HABITAČ̃o}

3.1. Projeto Arquitetônico.

3.1.1. Você teve acesso ao projeto arquitetônico (e aos demais projetos)? Tem uma ideia global do projeto ou apenas das etapas das quais é responsável?

3.2. Dinâmica de Aplicaçáo e Gestáo dos Recursos.

3.2.1. Houve atrasos no seu pagamento? Se sim, por quais motivos? 3.2.2. Quanto você ganhou por cada empreita realizada até agora? Foi por transferência ou com dinheiro?

3.2.4. $\mathrm{O}$ valor pago neste projeto é maior, menor ou igual ao valor pago em outros projetos (inclusive na cidade)?
3.3. Trabalho no Canteiro de Obras.

3.3.1. Como foi o processo da sua contrataçâa? Você foi indicado? Se sim, por quem? Você assinou algum contrato com a empresa?

Você se especializou em alguns serviços específicos? 3.3.3. Você trabalha todos os dias? Se não, quais dias da semana você dedica à obra?

3.3.4. Como foi a organizaçăo das equipes de trabalho nos canteiros de obra? Você tem uma equipe fixa?

3.3.5. Você indicou/convidou algum trabalhador auxiliar? Quem

3.3.6. Houve algum conflito durante as obras? Quais? Por quais motivos? Como foram relacionados?

3.3.7. Houve alguma reclamaçáo com relação à qualidade do seu serviço? Qual?

3.3.8. A empresa disponibilizou algum EPI para a realizaçấo do seu trabalho? Você se machucou durante a execução de algum serviço? Se sim, qual a gravidade do ferimento? Como foi a prestaçăo de socorro? Houve alguma dificuldade?

3.4. Fornecimento de Materiais e Equipamentos.

3.4.1. Você participou/ajudou com as entregas de materiais (descarregamentos, verificaçoes, estoques)?

3.4.2. Você utilizou alguma ferramenta particular na obra? Houve perdas, roubos, furtos e danificaçoes? Se sim, quem arcou com estes problemas?

3.4. Avaliaçōes e Perspectivas.

3.4.1. Qual a sua avaliação com relação à participaçáo neste projeto e com relaçáo ao PNHR? Você acha que o programa pode ser melhorado?

3.4.2. Qual a sua avaliaçáo com relaçáo à qualidade dos materiais? Você moraria na casa que você ajudou a construir?

3.4.3. Você se aperfeiçoou (em), ensino ou aprendeu algum ofício? 3.4.4. Como foi sua relaçáo com as famílias, a $\mathrm{EO}$ e a empresa? 3.4.5. Você pretende seguir trabalhando na construçáo civil? 3.4.6. Você pretende fuzer algum arso (trénico profisionlizante, superior)?

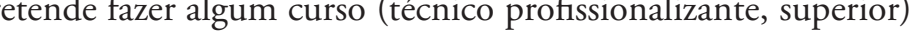
Onde? 